\title{
A Handbook for Tax Simplification
}

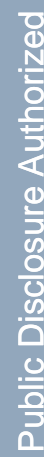
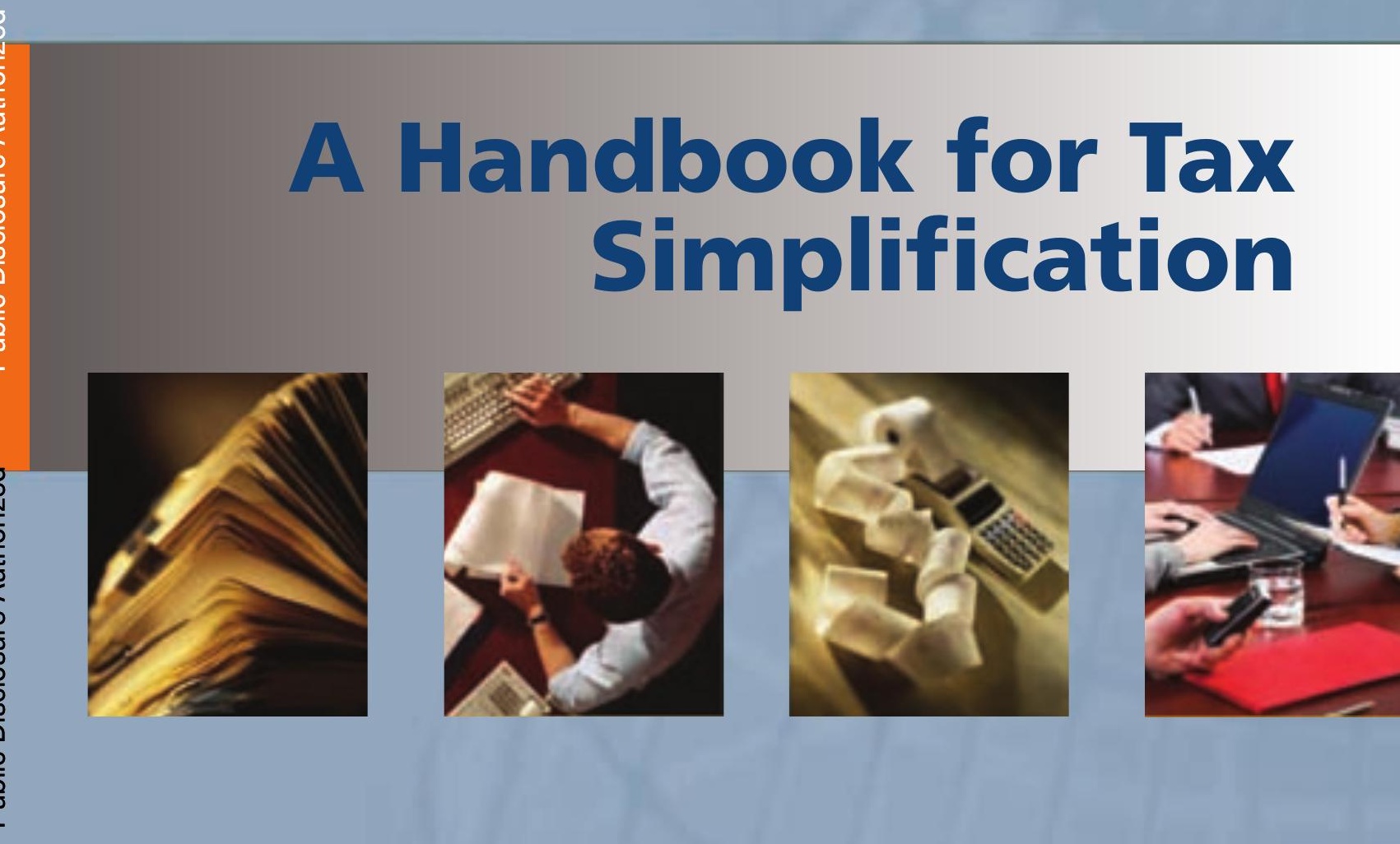

Investment Climate Advisory Services I World Bank Group
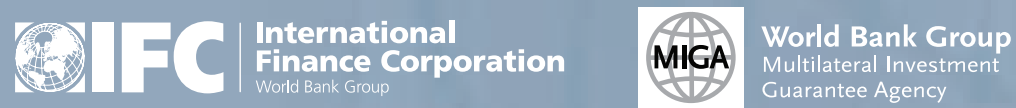


\section{A Handbook for Tax Simplification}

Investment Climate Advisory Services of the World Bank Group

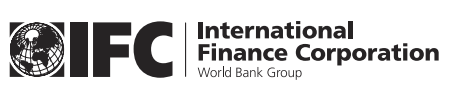

World Bank Group 
C2009 The World Bank Group

1818 H Street, NW, Washington D.C., 20433

All rights reserved

Manufactured in the United States of America

First Printing: November 2009

This information, while based on sources that the World Bank Group considers to be reliable, is not guaranteed as to accuracy and does not purport to be complete.

The findings, interpretations, and conclusions expressed in this work are those of the authors and do not necessarily reflect the views of the Board of Executive Directors of the World Bank or the governments of the countries which they represent. The information in this work is not intended to serve as legal advice.

The World Bank Group does not guarantee the accuracy of the data included in this work and accepts no responsibility for any consequences of the use of such data.

The denominations and geographical names in this publication are used solely for the convenience of the reader and do not imply the expression of any opinion whatsoever on the part of the International Finance Corporation, the World Bank, or other affiliates concerning the legal status of any country, territory, city, area, or its authorities, or concerning the delimitation of its boundaries or national affiliation.

\section{Rights and Permissions}

The material in this publication is copyrighted. Copying and/or transmitting portions or all of this work without permission may be a violation of applicable law. The International Finance Corporation encourages dissemination of its work and will normally grant permission to reproduce portions of the work promptly.

For permission to photocopy or reprint any part of this work, please send a request with complete information to the Copyright Clearance Center Inc., 222 Rosewood Drive, Danvers, MA 01923, USA; telephone: 978-750-8400; fax: 978-750-4470; online at: www.copyright.com.

\section{About the Investment Climate Advisory Services of the World Bank Group}

The Investment Climate Advisory Services of the World Bank Group helps governments implement reforms to improve their business environment, and encourage and retain investment, thus fostering competitive markets, growth and job creation. Funding is provided by the World Bank Group (IFC, MIGA, and the World Bank) and over fifteen donor partners working through the multi-donor FIAS platform. 


\section{Acknowledgments}

The publication of this handbook was made possible due to the generous support of the UK Department for International Development (DFID) under the partnership program between DFID and the Investment Climate Advisory Services of the World Bank Group. The primary author of this handbook is Sebastian S. James from the Investment Climate Department of the World Bank Group. The book was co-authored by Arindam Das-Gupta, Max Everest-Phillips, and François Vaillancourt (University of Montreal). This project was supervised by Richard Stern, Global Product Specialist (Business Taxation), Investment Climate Department. The final version of the handbook benefited from the contributions of Kobina Daniel, Geoffrey Walton, Jacqueline Coolidge, Laurent Corthay, Komal Mohindra, Jan Loeprick, Rajul Awasthi, Aminur Rahman, Stefan Van Parys, Umar Shavurov, and Shaela Rahman from the World Bank Group; Geerten Michielse, Professor in Tax Law at the Utrecht School of Law and Husam Al-Sharjabi (Apex Consulting). 


\title{
List of Abbreviations
}

\author{
AETR average effective tax rate \\ AFC Alliance for Change \\ ATIS automated tax information system \\ BIR Board of Inland Revenue \\ BPR business process reengineering \\ CARD Computer-aided Administration of the Registration Department \\ CATA Commonwealth Association of Tax Administrators \\ CCAs Compliance Cost Assessments \\ CCRs Compliance Cost Reviews \\ CDs compact discs \\ CEMAC Communaute Economique et Monetaire de l'Afrique Centrale \\ CFA Franc des Colonies \\ CIC Corporate Investment Committee \\ CIT corporate income tax \\ CMI Census of Manufacturing Industries \\ CRA Canada Revenue Agency \\ DAC Development Assistance Committee \\ DBI doing business indicator \\ DFID Department for International Development \\ ECLS electronic letter creation system \\ ECR electronic cash register \\ EPZs export processing zones \\ EU European Union \\ FAD Fiscal Affairs Department \\ FDI foreign direct investment \\ FIAS Foreign Investment Advisory Service \\ FTZs free trade zones
}


GDP gross domestic product

GST goods and services tax

HMRC HM Revenue and Customs

HSN harmonized system of nomenclature

HST harmonized sales tax (Canada)

ICSs investment climate surveys

ID identification

IFC International Finance Corporation

IFS Institute for Fiscal Studies

IGR general revenue tax

IMF International Monetary Fund

INTOSAI International Organization of Supreme Audit Institutions

IRS Internal Revenue Service

IT information technology

ITAA Income Tax Assessment Act

ITC investment tax credit

ITD International Tax Dialogue

ITD income tax department

LTUs large taxpayer units

MDAs ministries, departments, and agencies

MECF marginal efficiency cost of funds

MENA Middle East and North Africa

METR marginal effective tax rate

MISs management information systems

MoE Ministry of Education

MoF Ministry of Finance

MSE micro and small enterprise

MTI Ministry of Trade and Industry

NRA National Revenue Authority

NTA National Tax Association

OECD Organisation for Economic Co-operation and Development

PAN permanent account number

PAYE pay-as-you-earn

PPS prescribed payment system

PSI preshipment inspection

PWC PricewaterhouseCoopers 
R\&D research and development

RCE relative cost effectiveness

ROI return on investment

SADC Southern African Development Community

SAIs Supreme Audit Institutions

SARS South African Revenue Service

SAT Guatemala Tax Administration

SCM standard cost model

SEC Securities and Exchange Commission

SEZs special economic zones

SME small and medium enterprise

SMEDA small and medium enterprise development authority (Pakistan)

TA tax administration

TAA Tax Administration Act

TAS Taxpayer Advocate Service

TCMP Taxpayer Compliance Monitoring Program

TD tax determination

TI Transparency International

TIC Tanzania Investment Centre

TIN taxpayer identification number

UMEOA West African Economic and Monetary Union

URA Uganda Revenue Authority

VAT value-added tax

VFM value-for-money

WAEMU West African Economic and Monetary Union

WBES World Business Environment Survey

WWW World Wide Web 


\section{Table of Contents}

Reading Guide ........................ $\ldots \ldots$

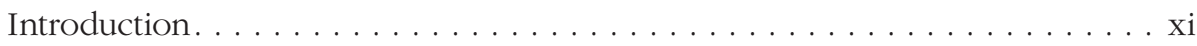

Chapter 1: Why Simplify Taxes?. . . . . . . . . . . . . . . . . 1

Chapter 2: The Political Economy of Tax Simplification . . . . . . . . . . 11

Chapter 3: Measuring the Burden of Business Taxes . . . . . . . . . . . . . . 29

Chapter 4: Simplifying Tax Policy . . . . . . . . . . . . . . . 61

Chapter 5: Tax Administration Simplification

(Reorienting the Tax Authority) . . . . . . . . . . . . . . . . . . 75

Chapter 6: Tax Administration Simplification

(Ensuring Compliance and Accountability) . . . . . . . . . . . . . . . . 111

Chapter 7: Fiscal Incentives and Investments . . . . . . . . . . . . . . . 145

Chapter 8: Corruption and Tax Simplification . . . . . . . . . . . 171

Chapter 9: Simplifying Subnational Taxes . . . . . . . . . . . . . . . 191

Chapter 10: Taxpayer Education and Assistance. . . . . . . . . . . . . . . . 213

References . . . . . . . . . . . . . . . . . . . . . . . . . . 225 


\section{Reading Guide}

Topic

Chapter

What are popular tools for measuring and evaluating tax reforms? 3

How do we measure the tax-compliance costs borne by businesses? 3

How are cost-of-compliance surveys conducted? 3

How are Doing Business surveys useful for measuring the business tax burden?

How do we calculate effective tax rates to measure the tax burden on businesses?

Why do we need an average effective tax rate (AETR) and in what cases is it useful?

What is METR and how is it useful to measure the tax burden on investment? 3

What is the role of Tax and Book Accounting in tax simplification? 4

How can we deal with the issue of proliferation of taxes? 4

How do we go about eliminating, consolidating, and retaining taxes and how does the tax guillotine help? 4

How do we tackle the issue of complicated tax codes and how does simplified tax law drafting help?

Why do regulations sometimes require taxes and what happens when they are overused?

How do we deal with the proliferation of sub-national taxes?

How could we use process maps to simplify tax procedures?

What are the simplified means of filing tax returns? 5

How can we use information technology to simplify taxes? 5

What are the simplified options to pay taxes? 5

How do we simplify the tax administration architecture and improve their effectiveness? 
Why is taxpayer registration important and how does it help compliance?

What is the role of withholding taxes in encouraging compliance and how do we manage it?

What are the various tools that tax administrators use to improve tax compliance?

How do we simplify audit procedures to reduce the burden on business? 6

How do we deal with tax issues in the case of business bankruptcy? 6

How can we use risk-based audits/assessment to reduce arbitrary audits? 6

How can we make the appeals process accessible and taxpayer friendly? $\quad 6$

What are the various tax incentives being used to attract investment? $\quad 7$

How do we increase transparency in granting tax incentives?

What are tax holidays and why are they bad for governments?

How have tax incentives been used to encourage investment and are they effective?

How does transfer pricing make tax incentives a revenue-losing proposition? $\quad 7$

How do we use tax expenditures to increase transparency in the use of tax incentives?

What are the ways to reduce administrative corruption through tax simplification?

How do we handle disputes between taxpayers and tax administrators on corruption?

How do we use external and internal audits to tackle administrative corruption?

What is the role of the ombudsman in tackling corruption and addressing taxpayer complaints? 8

How do we use technology to tackle corruption? 8

What are the various best practices in taxpayer education and assistance? $\quad 10$ 



\section{Introduction}

It has been well established by numerous Investment Climate Surveys, Doing Business surveys, and the work of the Foreign Investment Advisory Service in SubSaharan Africa and the Middle East and North Africa that tax constitutes a significant barrier to investment. Vague tax provisions, multiple tax instruments, arbitrary implementation of tax laws, limited opportunities for redress of taxpayers' grievances, and laws that give excessive discretion to tax authorities trouble both investors and deter potential investors. But, important as the work may be, there have been limited efforts to address these issues in one place.

The purpose of this handbook is to provide policy makers with a framework to assess a tax system in its entirety, measure its various parameters and how it is administered, and define best practices for tax policy and administration that will yield a tax system that is simple and predictable and does not create an undue burden on private enterprise.

It must be emphasized that any agenda for tax simplification has to cover a wide swathe of issues. In the interest of being a quick source of information on the topic, this handbook is an overview. The interested reader is pointed to more detailed literature on any of the topics.

This handbook is primarily designed for policy makers and tax practitioners. The goal is to analyze the impact of income tax, the value added tax (VAT), and other local taxes that are imposed on business. This handbook does not analyze the effects of trade and labor taxes such as social security. The administration of the customs duty is unique and has been addressed extensively in the literature on customs modernization. Labor taxes primarily imposed on salaried individuals are not covered by this handbook, even though their incidence affects business. VAT has been included even though it is a tax on consumption because the administrative burden to comply with it is primarily on business.

Topics addressed in this handbook range from the principal policy considerations for any reform initiative to practical and user-friendly templates for implementing policy and measuring the effectiveness of reform. 



\section{Chapter 1: Why Simplify Taxes?}

The goals of most tax reforms have been to raise more revenue for government, achieve various economic and social goals, and improve the efficiency of the tax collection process. However, tax reforms in general have paid little attention to improving the tax system to make it easy for businesses and entrepreneurs to comply. This is especially true in developing countries. The cost of compliance with the tax system for business is not trivial; it constitutes a significant fraction of the actual tax owed. ${ }^{1}$ Some of these costs are indirect in nature and as a result tend to be underestimated. However, investment climate assessments (ICA) and tax cost of compliance surveys of the World Bank have revealed the magnitude of these costs.

\subsection{Taxation Is a Major Constraint on Doing Business}

In the World Bank's ICA surveys, tax rates were identified as a major constraint by 37 percent of businesses overall; 27 percent specifically identified the tax administration (TA) as a major constraint. Figure 1.1 shows that tax rates and administration are two of the top six constraints identified by businesses in nations outside the Organisation for Economic Co-operation and Development (OECD). This trend is consistent across all the regions of the world, as shown in figure 1.2.

In order to improve the investment climate, it is essential that the burden imposed by tax policy and its administration be lightened.

\subsubsection{Businesses spend considerable time and money fulfilling their tax liabilities}

Cost-of-compliance and doing business surveys collect information on the time that businesses spend and the costs they incur to comply with their tax liabilities. According to the Doing Business 2010 report, businesses spend an average of

\footnotetext{
1 Alm (1996) indicates that the cost of compliance could be as much as 24 percent of revenues of certain taxes.
} 
FIGURE 1.1 Constraints on doing business in non-OECD countries

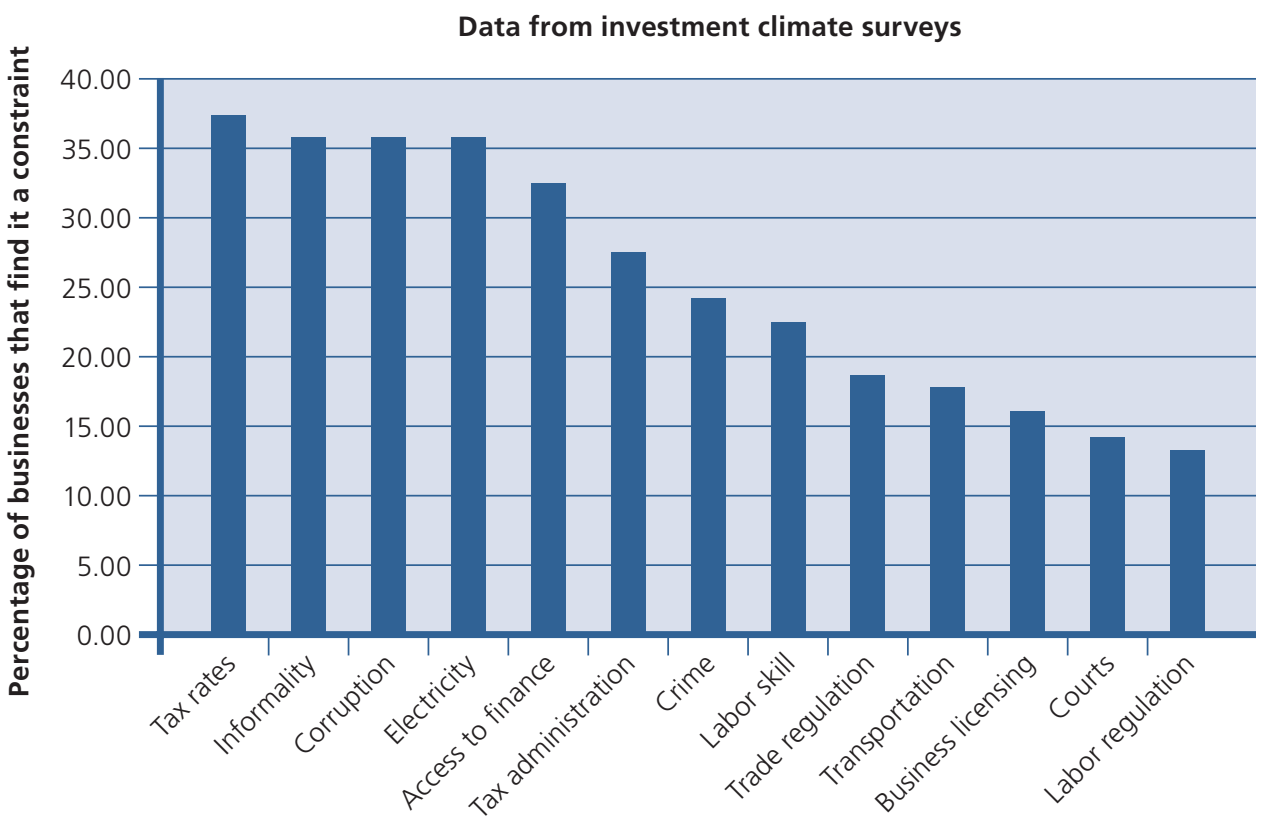

Source: World Bank's investment climate assessments.

FIGURE 1.2 Top constraints on business, by region

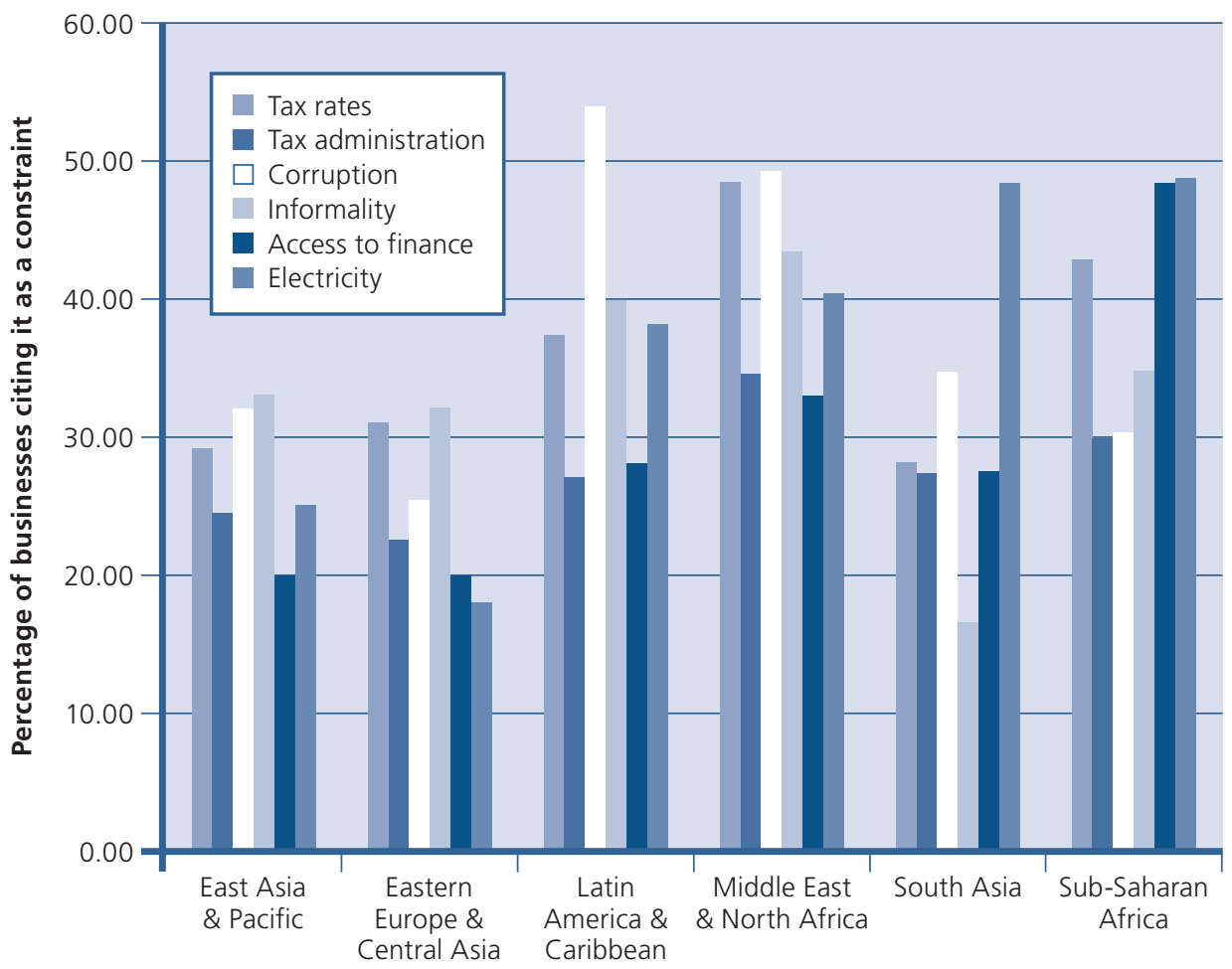

Source: World Bank's investment climate assessments. 
FIGURE 1.3 Time required to pay taxes in East Asia and the Pacific



Source: Doing Business (2010).

275 hours on 30 different tax payments per year. These numbers are corroborated by Foreign Investment Advisory Service (FIAS) cost-of-compliance surveys, which have found that a typical medium-size business in the Ukraine spends about 2,400 hours per year complying with tax liabilities; essentially, this implies hiring a fulltime accountant dedicated entirely to tax work. The time that businesses spend complying with taxes would be better spent performing the primary task of conducting the business.

Making it easier for businesses to pay taxes would result in cost savings and greater ease of doing business, which would encourage the growth of existing businesses and the creation of new ones. A better tax climate would also discourage informality. Eventually, this would result in a win-win situation: as businesses increase their performance, the government can collect higher tax revenues. 


\subsubsection{High tax-compliance costs drive the informal sector}

A high cost of complying with taxes may dissuade businesses from moving out of the informal sector. ${ }^{2}$ Such a cost reduces overall return on investment (ROI) and may make some businesses, especially small businesses, unviable. Surveys in OECD countries and in India reveal that compliance costs have a strong fixed-cost element. ${ }^{3}$ This implies that the burden is regressive, being higher for small businesses (that have smaller profits in absolute terms). For informal businesses, staying out of the formal system allows them to avoid taxes as well as the associated compliance costs. However, the process of staying informal in itself is not costless. Surveys of informal businesses in several countries have revealed that they spend substantial amounts as payments to authorities in order to remain informal. In the case of Sierra Leone, it was found that, in order to stay informal, some businesses end up paying more than the tax they would owe if they were not informal. ${ }^{4}$ The level of informality has wider implications, especially for formal businesses, which find themselves facing unfair competition from informal ones.

\subsubsection{Simplifying tax systems reduces corruption}

A simple tax system increases transparency and reduces-as far as possible-the points of contact between businesses and tax authorities. Such a system lowers the uncertainty of businesses that comply with the tax system and rewards good behavior. Frequently, tax procedures are made increasingly complicated by vested interests who want to increase their opportunities for rent seeking and bribes. However, reforms that simplify the tax system could thus face significant opposition from vested interests. Tackling corruption through tax simplification is discussed in chapter 8 . Another way to tackle corruption is to empower the taxpayers by making the tax system more accessible to the taxpayers through education and assistance. This is discussed in chapter 10 .

\subsubsection{A complex tax system discourages investment}

This is especially true in the case of discretionary tax incentives for long-term investments. As long as the option to lower their tax liability is available, all businesses will seek discretionary incentives in order to remain competitive. As a result, the overall investment climate deteriorates over time. A transparent tax system with set rules saves investors time negotiating with a government that approves them on a case-by-case basis. Such a system also reduces the opportunities for administrative corruption. This is discussed in detail in chapter 7.

\footnotetext{
2 By informal sector, it is implied those businesses that prefer not to register with government authorities, including tax authorities, despite being obligated to do so.

3 This implies that a significant portion of the compliance cost is a flat amount. See Chattopadhyay and Das-Gupta. 2002. "The Compliance Cost of Personal Income Tax and its determinants." NIPFP. India.

4 FIAS. 2006. (Sierra Leone) Informality Survey 2006. mimeo.
} 


\section{BOX 1.1 Egypt's Tax-Simplification Process}

In 2004 Egypt embarked upon a tax reform that included many of the good practices of a simplified tax system. The program:

- Removed several tax exemptions at the same time and decreased the tax on business profits from 40 percent to 20 percent.

- Simplified tax laws and aligned the definitions of several tax terms with international norms.

- Simplified the rules on tax depreciation, reducing the discretion of tax officials.

- Replaced tax-administration assessment with self-assessment.

- Replaced the compulsory audit of all tax returns with risk-based audits, increasing efficiency.

- Improved the appeals process by making it more accessible to taxpayers.

- Merged the sales tax and income tax departments, reducing taxpayers' compliance burden.

- Trained tax administrators in the new processes and reoriented them toward better serving the taxpayer.

The impact of the tax-simplification process was immediate. The number of tax returns filed jumped by 50 percent in just one year. Tax revenue increased from 7 to 9 percent of gross domestic product (GDP), even though tax rates were cut in half. While the time spent by corporations on filing taxes increased slightly (as measured by Doing Business surveys), the overall tax burden fell due to the reduction in tax rates.

Source: Ramalho 2007.

\subsubsection{Tax simplification improves compliance and reduces the cost of tax collection}

Simplifying a tax system also involves streamlining its administration, reducing redundancies and points of contact, and improving the efficiency of existing procedures. Improved procedures and processes (such as the use of automation and risk-based audits, reduced discretion, and so on) also reduce the costs of administering the tax system. Improved compliance-resulting from an improved investment climate and more accessible tax system-also contributes to lowering the cost of collection. This is discussed in chapters 5 and 6.

\subsection{Why Do Tax Systems Get More Complicated over Time?}

A strategy to simplify any tax system should take into consideration some of the pressures that complicate tax systems over time. We may note that such pressures are not always the result of poor policies. 


\subsubsection{A worthy goal: an administratively feasible tax system that is efficient and equitable}

The goal of simplifying a tax system is to increase the ease of compliance, reflected in the costs and time saved. An efficient tax system should allow taxpayers to calculate their tax liability easily, pay their taxes and file their tax returns, and redress their grievances with limited costs. In addition, it should include taxpayer-friendly methods for tax administrators to verify tax liability and ensure that correct taxes have been paid.

Taxes serve the primary task of raising revenue to provide for public goods and redistribute income; while these goals are central, the role of the tax system in regulating both positive and negative behavior, and directing the overall economy along a certain path, cannot be underestimated. Recent literature emphasizes the political economy aspects of taxation, especially its role in strengthening institutions even while collecting little or no revenue.

Economists have traditionally rated tax systems by their efficiency, equity, administrative feasibility, and simplicity. Administrative feasibility takes into consideration the fact that tax collection has a financial cost and that some taxes are cheaper to collect than others, for both businesses and tax administrators. An efficient tax system is one that minimizes distortions. For example, taxpayers might change their behavior in response to a particular tax, resulting in an overall loss even when taxpayer welfare and government revenue have been kept in mind. Thus, a turnover tax levied on production is less "efficient" than income tax, because the former induces businesses to lower their level of production, which reduces the tax base. However, the turnover tax imposed on producers is cheaper for a tax authority to implement because it is less complicated to quantify and verify than income tax. Similarly, a flat tax on income is cheaper to administer than a progressive personal income tax, but it is also less equitable.

In sum, reaching the goal of a simplified tax system has to balance the competing goals of efficiency, equity, and administrative ease. The importance of administrative ease can be gauged from the fact that the cost of compliance for taxpayers can, at times, exceed the efficiency cost of taxes; as a result, the goal of a simple tax system can trump the goal of an efficient one (Alm 1996). A simple tax system is also cheaper for tax administrators to implement and reduces the cost of tax collection.

Tax experts agree that a good tax has a low rate and a broad base. This principle captures, to a large extent, the goals of equity, efficiency, and administrative feasibility.

\subsubsection{Compliance requirements serve a useful purpose}

Compliance requirements are used by tax administrators to ensure that more taxes will be filed. But they also burden businesses with extra obligations. For example, the requirement to maintain records, make them readily available for inspection by 
tax administrators, and even, at times, expect that these records be audited by external tax auditors imposes costs on businesses. These are the main tools tax administrators use to improve compliance. Similarly, tax administrators use withholding taxes as a means to collect taxes, especially from those taxpayers more likely to evade their tax liability. But withholding taxes pushes the cost of collection onto the taxpayers who are now assigned the task of withholding agents. Any tax-simplification process that reduces these and other requirements has to take into consideration that lower requirements could affect the efficiency of administering taxes. This is discussed in chapter 4 .

\subsubsection{Some compliance requirements may be excessive}

Some mandatory requirements, on the other hand, may not ensure higher compliance even while imposing high costs on businesses. These may result from:

- A false notion among some tax administrators that the more the reporting requirements, the higher the compliance by taxpayers

- Vested interests that seek to increase contact between the TA and businesses for the purpose of rent seeking

- Duplicate requirements by multiple agencies.

\subsubsection{The use of regulations as tax-collection instruments by subnational governments}

A significant contributor to increased tax complexity is the levying of multiple taxes by subnational governments. This is primarily the result of subnational governments' limited power to raise revenue. Hence, they tend to create multiple regulations and use the resulting licenses and fees to fund their expenditures.

\subsubsection{Complexity of the tax laws}

While the large number of taxes increases the complexity of the tax system, the tax laws by themselves become increasingly complex over time because they must keep up with the creation of new financial instruments and innovations in tax avoidance. International taxation is one of the leading causes of tax law complexity, because of transfer pricing rules and the various double-taxation avoidance treaties that countries have with each other. These impose significant compliance costs on business. Slemrod and Blumenthal, in a survey of 1,672 U.S. firms, found that the costs these companies incur to comply with U.S. international tax laws was about 39 percent of their overall tax compliance costs; these are even higher, at 44 percent, for the Fortune 500 companies.

\footnotetext{
5 3. Marsha Blumenthal and Joel Slemrod. 1995. "The Compliance Costs of Taxing Foreign-Source Income: Its Magnitude, Determinants, and Policy Implications." International Tax and Public Finance, vol. 2, no. 1, 37-54.
} 
FIGURE 1.4 Tax administrators and businesses usually do not share the same point of view

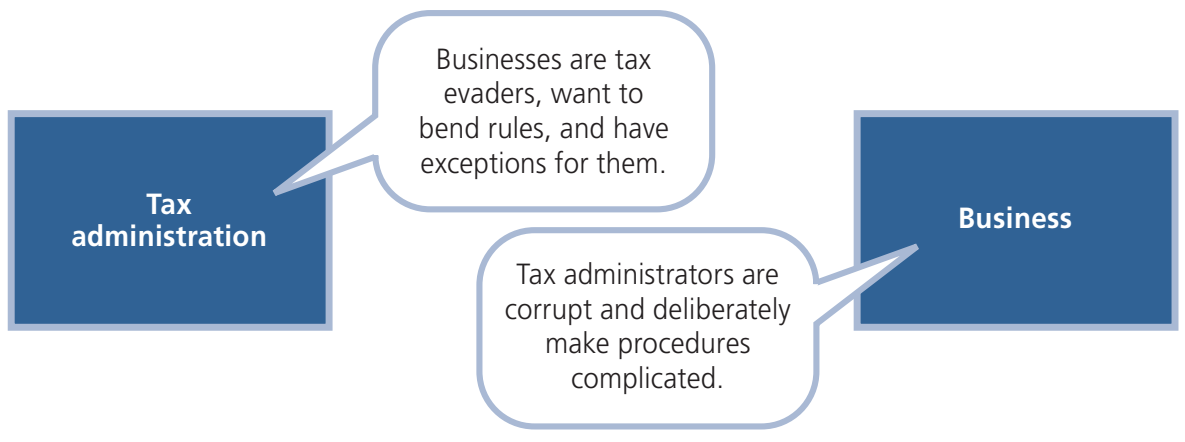

As businesses devise new and complex financial instruments and find new ways to avoid taxes through complex financial instruments and special vehicles, governments are under pressure to keep up with them. As a result, it is inevitable that the tax law reflects the complexity of the financial environment.

Tax laws are among the most dynamic pieces of legislation coming under pressure to serve various economic and social goals of the government, and as a result they are amended often. Another reason tax laws are complex is the increasing amount of litigation on the intent of law brought before courts. In case the decision of the courts is not what the government expects, the laws are then amended to reflect their view. All these pressures result in a patchwork of amendments that make the tax laws increasingly complex over time. This necessitates a clean-up, with the tax laws having to be rewritten; however, as the pressure for increasing complexity does not stop, tax law complexity displays cyclical patterns.

\subsection{Tools for Tax Simplification: A Sneak Peek}

A strategy to simplify the tax system requires several inputs. Each tool provides the policy maker or advisor with the necessary inputs to simplify the tax system:

- Using tax-compliance cost surveys to understand the time and cost of paying taxes and the instruments responsible for this burden

- A tax inventory, including a subnational tax inventory, of the several licenses, fees, and taxes that businesses have to pay

- Process maps that illustrate various administrative procedures, with special emphasis on those that generate points of contact with taxpayers (figure 1.5 is one such process map used by the TA of Yemen).

The next chapter addresses the important issue of the political economy dimension of tax simplification. 
FIGURE 1.5 A process map for the large taxpayer unit in Yemen

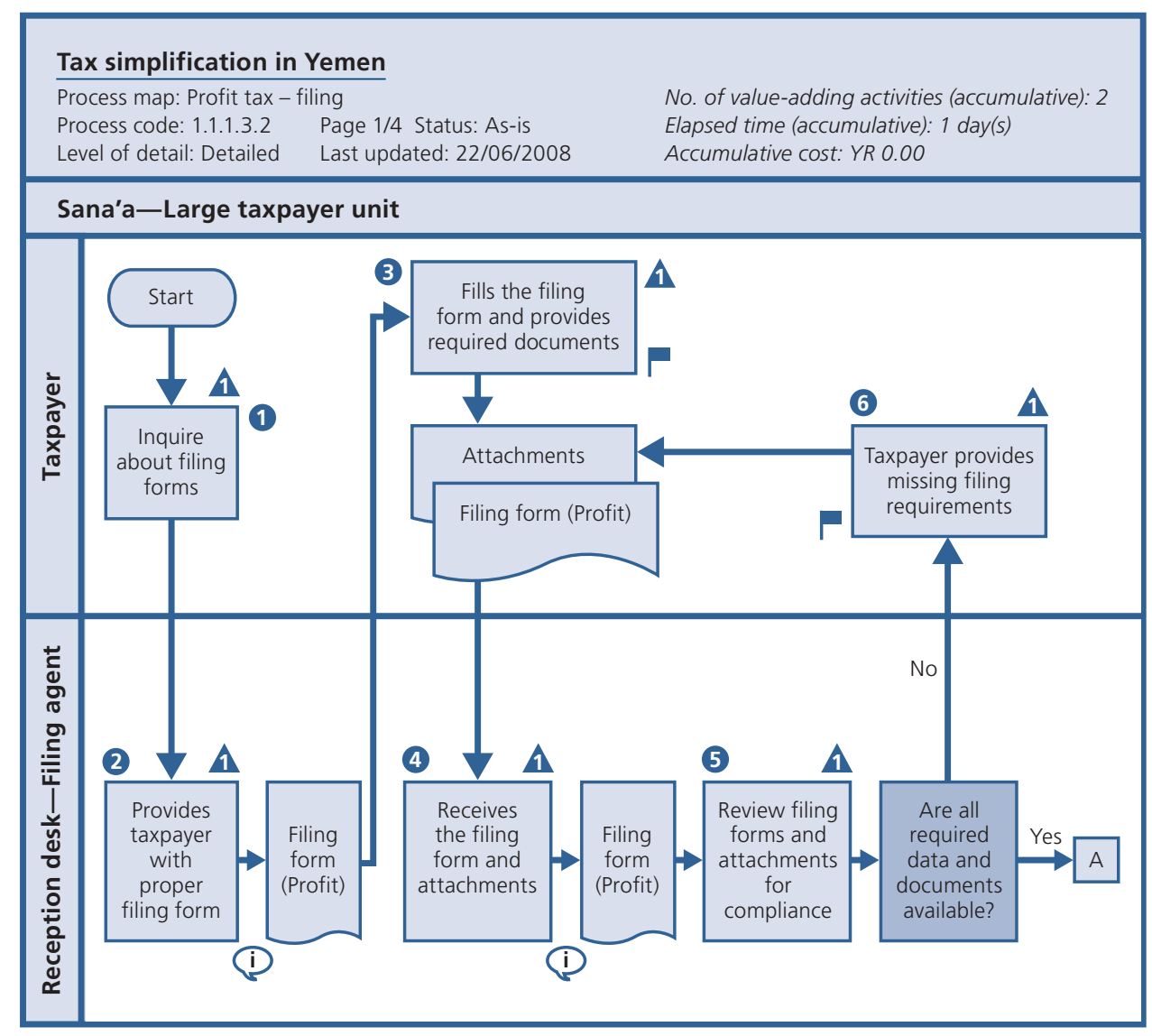

\section{Further Guidance}

Investment Climate Advisory (FIAS) four-page notes on:

- Local Taxes, Regulations, and the Business Environment: Finding the Right Balance

- Introducing the Value-Added Tax: Considerations for Implementation

- Tackling Corruption through Tax Administration Reform

- Linking Business Tax Reform with Governance: How to Measure Success

- Small Business Taxation: Reform to Encourage Formality and Firm Growth

These can be accessed at http://www.fias.net/ifcext/fias.nsf/Content/Pubs_BusinessTaxation. 



\section{Chapter 2: The Political Economy of Tax Simplification}

\section{CHECKLIST OF GOOD PRACTICES}

$\checkmark$ Understand the tax system's complexities and their political rationale

$\checkmark$ Undertake detailed political economy analysis of the potential benefit of each complexity

$\checkmark$ Move the focus of the tax administration (TA) away from coercion toward contractual agreement

$\checkmark$ Undertake surveys to identify administrative and institutional challenges to taxpayer morale

$\boldsymbol{\checkmark}$ Undertake detailed political economy analysis of potential "drivers of change"

$\checkmark$ Pay attention to the tax system's important role in building state capacity

\subsection{Why Simplification Is Not Simple}

"Everything should be made as simple as possible_but not simpler."

-Albert EINSTEIN

Everyone, everywhere, agrees that tax systems should be simplified, yet each year tax codes grow longer and more convoluted. The problem is far from new. In 1377, the great medieval Arab polymath Ibn Khaldun wrote: "At the beginning of the dynasty, taxation yields a large revenue from small assessments. At the end of the dynasty, taxation yields a small revenue from large assessments" (Muqaddimah 1958). Why? All tax systems grow more complex alongside accumulated accretions of statutes, regulations, administrative practices, bureaucratic conventions, and evolving societal norms. The accidental combines with the deliberate, whether attributable to political strategy or political trade-offs.

Noncoercive tax is a political agreement (a "fiscal social contract") negotiated between citizen-taxpayers (and those legislating on their behalf) and the state (the executive) over national purpose, political rights, obligations, and the accountability of government to its citizens. As Zakaria (2003:76) notes, "When a government taxes 
people, it has to provide benefits in return, beginning with services, accountability, and good governance but ending with liberty and representation. This reciprocal bargain-between taxation and representation-is what gives governments legitimacy in the modern world." The political challenge of tax simplification is to ensure its salience with the fiscal social contract. Tax is an expression of social capital. Reforming taxation reflects a debate about the kind of society that citizens desire and are willing to pay for (Hettich and Winer 2000:44-73). Political leadership backed by technical competence is critical: Egypt's 2005 success in simplifying taxes and reducing rates to broaden its tax base, and thus increase revenue, is a striking example of how to get it right. When, then, does it pay to reduce the complexities inherent in providing different treatment for different taxpayers (or political favors for special interests) in return for lowering the overall tax burden of all taxpayers?

Simplification is not an end in itself, but a means toward greater transparency, predictability, and fairness in the tax system. It is futile to believe that simplifying taxes will simplify the complexities of the nation itself. Complexity is the inevitable result of the fact that "the politically optimal tax structure requires marginal political opposition per dollar of tax revenue to be equalized across taxable activities for each taxpayer, as well as to be equalized across taxpayers for each activity" (Hettich and Winer 1988:705). Even reforms expressly aimed at simplification can, after political bargaining, make a complex tax code even more complex (Steinmo 1993:167-69). Tax simplification must also avoid the ideologically driven concept of "rolling back the state," a modern version of a 19th-century political debate in western Europe and North America about the role and function of the state as "tax eater" and the evolution of middle-class political identity (Wahrman 1995). ${ }^{1}$

Interventions meant to simplify tax systems should aim at, rather than create, better, more effective government. This suggests a typology of tax system complexities:

- Coercive complexity of methods to tackle tax avoidance and evasion

- Political complexity to address coalition trade-offs and the lobbying influence of vested interests, and reward key parts of the electorate

- Equity complexity as a political device to signal credible commitment to social equity and the delivery of redistributive justice

- Legal complexity to pin down meanings

- Expenditure complexity-Wicksell's connection of tax systems to choices concerning public expenditure

\footnotetext{
1 Effective national taxation is perhaps the best indicator of the continuing effectiveness of the nationstate in the face of supposed global pressures toward state diminution or disintegration (Garrett 1998).
} 
- Constitutional complexity - the result of an unclear fiscal arrangement between different levels of government ${ }^{2}$

- Efficient complexity to create "handles" on the structure of the economy, also shaped by the different political economy influences on each sector

- Accidental complexity from the accretion of past practices

- Corruption complexity that facilitates greed as well as the off-budget funding of political stabilization

- Administrative complexity such as inefficient levels of official discretion ${ }^{3}$

Any effective simplification strategy must be clear about which type of complexity it is attempting to address. For example, when David Lloyd George, a Chancellor of the Exchequer (finance minister) in the United Kingdom in the early 20th century, received a paper from the Board of Inland Revenue (BIR) expounding the technicalities of the estate duty charge on settled property, he rejected the document and demanded a simpler explanation. The BIR sent the simplified explanation requested; but as the problem remained as complicated as before, the simplification merely made the proposed solution harder to understand (Johnson 1965). The scale of tax legislation reflects socioeconomic tax complexity; that can be illustrated by the number of pages of primary tax legislation in most nations (for example, 8,300 pages in the United Kingdom; 7,200 in Japan; 5,100 pages in the United States-not including further legislation at subnational levels). A page count, of course, is only a crude measure of complexity, since all tax systems also have secondary legislation in the form of regulations, case law, revenue authority interpretations, and formal tax rulings.

So reform may require a separate approach to tackling the root of each complexity. A coherent strategy for simplification is required, based on establishing the relative importance of simplification compared to other aspects of the tax system. Progress toward tax simplification and other goals requires a mechanism for monitoring reform on a permanent basis. Reformers must understand the trade-offs: efforts to make taxes "simpler" may conflict with efforts to make taxes fairer-and may contradict calls by the international community for developing countries "to bring politics back into tax and fiscal policy-making, explicitly and transparently" (OECD 2007b:3).

\footnotetext{
2 In both federal and unitary states; see Bernstein and Lu (2008) on the mushrooming of taxes, fees, fines, license, and apportionments in China in recent decades.

3 Of course, clearer functional specialization within tax offices-the separation of functions such as processing returns, auditing, and receiving payments-is likely to help reduce corruption (Tanzi and Zee 2000).
} 


\title{
2.2 The Political Rationale for Tax Complexities
}

\author{
"Seek simplicity but distrust it."
}

-Alfred Whitehead

Most variation in tax structure across countries is the result of differences in political and institutional factors (Merrifield 1991:295-311). Tax systems may have many-sometimes conflicting - aims. Even in their simplest form, they seek to promote horizontal and vertical equity; in the balance between ability to pay and the benefits received, redistributive justice requires exceptions, exemptions, deductions, write-offs, special rates, and other complications, all designed to accommodate taxpayers' varying ability to pay and varying political clout (Steinmo 1993:30-34). Tax simplification must be salient to the political incentives, administrative and judicial processes, societal divides, economic structures, and revenue ambitions set by public service levels-in other words, balance political bargaining with concerns about equity, the economy, and the rationality of taxation. "The prospects of substantial tax reform can be no more than a reflection of those for real change in the political and social balance" (Bird 1970:197). Efforts to make taxes fairer and less distortionary may conflict with attempts to make taxes simpler, or to raise revenue. ${ }^{4}$ Simplification is often carried out as an ad hoc initiative without adequate political consensus, so that when the initial momentum fades, the inherent pressures for complexity resurface. All revenue authorities also face the constant problem of enforcing compliance, requiring ever more complex rules to tackle increasingly sophisticated and complex tax-avoidance strategies. Many developing countries also face the further challenges of large informal sectors, poor information, weak political support, and widespread corruption.

Taxation is as much "political theater" as effective social policy. The politics of fiscal gestures add complexity at the cost of administrative effectiveness, economic efficiency, and social welfare. Technical evidence, such as that "providing relief to the poor through exemptions and VAT zero-rating is likely to be both unsound policy and ineffective social policy" may often be ignored when political perceptions matter. In the United States, for example, both the legislature and judiciary are blamed: "The United States Congress has taken pains to enact confusing, verbose, and ambiguous tax statutes requiring complex logical and/or mathematical gymnastics to arrive at the correct tax. Many of these instances are modifications of statutes whose prior incarnations have been interpreted by the courts in a manner not consistent with legislative intent" (Ryesky p. 96).

\footnotetext{
4 Shome (2004) points out that simplified regimes for small taxpayers tend to be a political and practical compromise, requiring less revenue from these key constituencies in the electorate compared to their revenue potential.

5 The 1994 Katz Commission in South Africa.
} 
A similar dynamic can be found in many developing countries. ${ }^{6}$ Complex tax structures are the result of revenue bargaining and the "politics of fairness." Redistribution through tax-based social welfare programs promotes equity and economic efficiency but depends on the increasing complexity of the economy and the political lobbying of vested interests (Alesina and Angeletos 2003). The lasting political feasibility of a "flat tax" in different political economies remains unclear, but it is interesting that it has mainly been adopted in small colonies such as Hong Kong (since 1947); dependencies such as the Channel Islands; and Eastern European states such as Estonia (1994), Serbia (2003), and Slovakia (2003), with a political consensus putting economic growth and political stability above equity. ${ }^{7}$ A major exception is Russia, where the success of the introduction of the flat tax in 2001 appears to be the result, at least in part, of taxpayers perceiving no alteration in the complexity of the tax system (Ivanova, Keen, and Klemm 2005:397-444).

Slemrod (1984) defined the complexity of a tax system as the sum of compliance costs (incurred by individuals and businesses) and administrative costs (incurred by the government). So, tax complexity reflects structural elements such as the tax base; the tax rate structure; and the allowable deductions, exemptions, and credits as well as the administrative features of the tax code. Simplification reduces compliance costs and unintentional tax evasion, and increases compliance through improving the taxpayer perception that the tax system is fair. But simpler taxes also reduce the ability of policy makers to achieve the tax policy aims of improving equity, reducing tax evasion, and promoting socially beneficial behaviors. Politicians and interest groups seek to reduce taxes for particular individuals, ${ }^{8}$ groups, sectors, or activities, making taxes more complex by creating more distinctions among taxpayers and their sources and uses of income, with complex outcomes for tax morale.? In Uganda, the initial success of taxation reforms in the 1990s is attributed to reduced political interference (Kangave 2005:145-76). In Sierra Leone, despite the successful creation of the National Revenue Authority (NRA) in July 2003, the tax morale and culture of tax compliance remain contingent on politics. During the hotly contested election period in August 2007, tax collection collapsed, with taxpayers withholding payments as they awaited the political outcome. As Wagner (1985) argues: "There is no possibility of determining a 'good' tax system independently of a consideration of the interests and values of the people who constitute the polity."

\footnotetext{
6 For example, Easter (2008) on Russia in the 1990s.

7 Such as in the case of the higher political ambition of EU membership, which may explain Ukraine's adoption in 2003. Russia's 2001 introduction of the flat tax sought to tackle rampant corruption and the enormous size of the informal economy, which had reached 40 to 60 percent by the late 1990s; see Johnson (1998:387-432).

8 See Ryesky op. cit., for U.S. examples; for example, Hollywood mogul Louis B. Mayer.

9 For example, Tanzi and Zee (2000) reported that many developing countries had different rates of corporate income tax for different sectors, such as in Egypt, Paraguay, Vietnam, and Zambia.
} 


\subsubsection{Representation without taxation}

Tax complexity is the outcome of the politics of equity. The concepts of "vertical" or "horizontal" equity are politically contested in tax systems. Vertical equity requires the rich to pay more because the "degree of utility of income decreases when income increases," so a "just" tax system that treats citizens "equally" would be progressive. Horizontal equity requires those with similar economic resources to bear similar tax burdens. Where inequality and poverty are widespread but democracy has extended the vote to all adults, most voters are not taxpayers. Voters may be inclined to support progressive taxation and heavy public expenditure. Citizens, as recipients of public goods, may vote for higher public spending; meanwhile, citizens, as taxpayers, may seek lower public expenditure-so the ratio of voters to taxpayers will shape political dynamics for effective tax reform. In the 19th century, political leaders in Western Europe and the United States were concerned that voters should be taxpayers with an economic stake in society. They feared that enfranchised nontaxpayers would vote for irresponsible fiscal proposals, thereby hindering sustainable growth and their own long-term economic prospects (Alesina and Rodrik 1991).

In developing democracies, inequality means most voters are not taxpayers. In Bangladesh, less than 1 percent of the population falls within the tax net, with 4 percent of taxpayers (or less than 0.4 percent of the population) paying 40 percent of the tax revenue, while 50 percent of taxpayers (less than 0.5 percent of the population) pay less than 1 percent of the total tax revenue (Sarker and Kitamura 2006). In Tanzania, from a population of 35 million, 286 taxpayers pay almost 70 percent of domestic taxes; in Peru, less than 1 percent of taxpayers pay more than 85 percent of direct taxes (Brautigam and others 2008:256-7). One way to handle the tension between inequality and democracy is through complex tax systems that achieve political consent but enforce taxation selectively and so fail to raise the expected revenues, thereby capping expenditure (Guyer 1992:41-79; Ribot 2000:505-67).

An alternative strategy can be seen when, outnumbered in the ballot box, elites deliberately foster complex tax systems to create legal and institutional obstacles to effective collection, which seems to be the case in Latin America-the most unequal region in the world, yet one where tax systems remain both regressive and ineffectual (Best 1976). As Mahon (2004:8) suggests, the rise of popularist politics in Latin America seems "to have pushed states even further from the prototypical relationship between taxation and formal representation, as the propertied gave up terrain in legislatures but kept their influence behind the scenes." Another strategy is tax-system complexity as a deliberate political ploy to discourage taxpayer-citizens from political mobilization and the development of a "fiscal social contract." As Moore (2008:55) observes: "a complex tax system with a variety of discretionary exemptions will tend to motivate taxpayers to neglect collective action and to engage instead in individualized strategies to solve their problems, whether through bribery or employing tax advisers." 
Complexity also facilitates corruption, as a result of either the greed of influential administrators and politicians or further political stability through off-budget funding (Khan 2006). As in the case of tax incentives and exemptions designed to protect the interests of powerful groups, tax administrators may offer legal exemptions in return for financing. ${ }^{10}$ In many developing countries, political influence is therefore significant in the selection and promotion of staff at all levels in the revenue administration. Complexity may also facilitate another variation in corruption arising from excessively low civil service salaries. As a result of both pressures, a 1997 FIAS study of taxation in Yemen found that "taxpayers frequently find themselves in a situation where officials will not accept their documents and records and they must negotiate with these officials for some settlement." Complexity may also result in efforts to reduce the bureaucratic discretion of revenue authority officials, which often fosters corruption. This is the result, in part, of a simplistic view of the relationship between discretion and corruption. In the United States, for instance, Internal Revenue Service (IRS) officials actually have great discretion and so can treat similar taxpayers quite differently. ${ }^{11}$ Instead, it is necessary to analyze the TA in the context of broader governance, as well as internal institutional design: for instance, in China in the 1920s and 1930s, the Sino-Foreign Salt Inspectorate managed to isolate its TA extremely effectively from the generally corrupt environment in which it was operating (Strauss 2008:229).

\subsubsection{Elites and tax complexity}

In developing countries where inequality and poverty are widespread but where democracy has extended the vote to all adults, most voters are not taxpayers and so will be inclined to vote for progressive taxation and heavy public expenditure. Elites as taxpayers seek lower public expenditure, so the ratio of voters to taxpayers and the relative size of the middle class and medium-size businesses (which are politically less able to secure tax exemptions, but not small enough to disappear into informality) will shape political dynamics and thus tax reform. As Bird (1992:7-36) succinctly points out: "major explicit tax changes are almost invariably political dynamite." The unsophisticated elite response is political repression to protect power over the tax base and the political system. As repression has generally become more difficult and costly, elites have bargained with the taxpaying middle class to form coalitions against popularist taxation. Elites extended the franchise to existing taxpayers, rather than, as more often suggested, seeking to tax new voters (as in 19th-century Europe). Having usually conceded full political emancipation in most developing countries, political elites have handled the challenge of a low taxpayer-to-voter ratio by devising

\footnotetext{
${ }^{10}$ For example, Gautier and Reinikka (2001) show that tax exemptions mainly benefit large firms in Uganda.

${ }^{11}$ For example, the infamous Sklar case over the IRS "special" treatment of the Church of Scientology: Sklar versus Commissioner, 282 F.3d 610 (9th Cir. 2002), aff'g, 79 T.C.M. (CCH) 1815 (2000).
} 
complex tax systems that achieve consent but enforce taxation selectively; facilitate evasion, avoidance, and exemptions; and so fail to raise expected revenues, thereby capping public expenditure (Guyer 1992:41-79; Ribot 2000:505-67).

Complexity is not just the result of an increasingly complex economy and elite tax-avoidance strategy, but may be a political device to signal "credible commitment" to targeting social equity. It can also be a deliberate political strategy to discourage taxpayer-citizens from political mobilization, undermining the "fiscal social contract" by fragmenting the treatment of the taxpaying electorate. And so Milton Friedman argued for a flat tax because, as he stated, "a simplified tax with low marginal rates would help restore confidence in government and would support the basic honesty of the American people." ${ }^{22}$ But in weak democracies with high inequality levels between elites and the vast majority of the population, the context is very different. Outnumbered in the ballot box, elites foster deliberately complex tax systems to create legal and institutional obstacles to effective collection. Thus, tax complexity can be the product of elite bargaining within the political "rules of the game." For example, the fragmented power structures under Yeltsin's Russia of the 1990s created a tax system of enormous complexity-by 1997, the tax code consisted of nearly 200 different taxes, augmented by 1,200 presidential decrees and government orders; 3,000 legislative acts; and 4,000 regulatory acts, while regional governments added more than 100 taxes of their own. At the same time, politically powerful elites had secured tax expenditure exemptions on an extraordinary scale, estimated at more than two-thirds of total taxes collected for the federal budget (Easter 2008:74-9).

\subsubsection{The risk of oversimplifying taxes}

The corollary to "no taxation without representation" may be "no tax simplification with effective democratic representation." In China, the income-tax legislation in the 1990s was extremely simple-14 clauses covering only 4 pages_-giving a large degree of unaccountable power to the TA to interpret it, especially in the absence of any effective judicial oversight or appeals process (Vording 1997:91-110).

\subsubsection{Revolutions start with the tax collector $^{13}$}

Simple taxes can be bad politics. The simplest taxes are often the most politically contentious and least legitimate, and therefore generate the worst tax morale and compliance. Some have even triggered violent resistance, such as the Peasants Revolt of 1381 over the Poll Tax in England, the Hut Tax revolt in Sierra Leone in 1898, and the Bambatha Revolt in Natal against both poll and hut taxes in 1906. The requirement of

\footnotetext{
12 Quoted in Nehring (2008:206).

${ }^{13}$ New York Times correspondent T. Millard in 1926 on China, quoted in Brautigam and others (2008:89).
} 
poll tax payments to vote was widely used after the Civil War in the United States to prevent poor people, especially African-Americans, from voting, until this electoral gerrymandering was finally banned by the 24th Amendment to the U.S. Constitution in 1964. The poll tax triggered the collapse of Thatcher's government in the United Kingdom in 1990 (called an "elective dictatorship"), suggesting that oversimplifying taxes represents a failure of the democratic process (Steinmo 1993:177-8; Butler 1994: 303). A similar phenomenon is identified in East Africa by Fjeldstad and Therkildsen (2008), who suggest that increasing democratization leads to the reform and decline of poll taxes (Brautigam and others 2008).

Tax simplification can be offset by complexity elsewhere; the broader policy mix also matters, as Winer and Hettich (2002:11) warn: "Any constraint on the use of a particular fiscal instrument, such as imposition of a 'flat' tax on income, may lead to the introduction of more special provisions in other tax bases, or to the increased use of policy instruments such as regulation, which can have similar economic effects on voters. Forced simplicity in taxation may thus lead to additional, and perhaps more obscured, complexity in other places" (italics added) (Hettich and Winer 2006: 355-80). Even the impact of a particular tax makes sense only in its political and social context; for example, Japanese income tax is asserted by some scholars to be grossly unfair to low- and middle-income taxpayers, while others depict it as the most progressive in the industrialized world; meanwhile, some claim that it is too progressive, hindering economic growth (Dewid and Steinmo 2002:159-78).

Tax simplification can therefore only be credible where the governance context enables reform. For example, tax reforms in Indonesia in the 1980s worked because of strong political leadership and motivation to increase "fiscal space" and tackle widespread tax evasion and enforcement problems (Winters 1996). These objectives were achieved in Chile when the post-Pinochet democracy was determined to uphold the "fiscal pact," administering fairer, more effective taxation in return for stronger economic growth and governance prospects. By comparison, the postmilitary political settlement in Argentina has never managed to find the political will to tackle tax reform and simplification, so compliance and tax morale remain low (Bergman 2003:593-624). Without improving tax morale, it is difficult to escape the vicious cycle of low compliance leading to more draconian enforcement and more opportunities for corruption in the tax authority, further worsening compliance. Across Latin America, generally, politics has shaped tax interventions, including simplification (Mahon 2004:3-30). In Tanzania, simplification of the tax structure during the last decade has seen a reduction in the marginal tax rate to 30 percent and personal income tax bands reduced to five; meanwhile, the increased income tax threshold (from TZS 20,000 to TZS 45,000 per month) has removed more than 40 percent of all taxpayers from the tax system (Fjeldstad, Hussein, and Shallanda 2002; Fjeldstad and Semboja 2000). 
Most relevant to reform is not the overall level of complexity generated by the political settlement, but whether the complexity is cost-effective in the local context, given the level of administrative capacity to enforce tax rules. The political and practical factors that generate complex tax systems-policy trade-offs, politics, and taxpayers' desire to reduce their own tax burdens-will otherwise quickly reestablish complexities after any tax system reform.

\title{
2.3 Tax and State Building: The Political Economy of Taxation
}

\author{
"Revenue is the chief preoccupation of the state. Nay more it is the state." \\ -Edmund Burke
}

"How people are taxed, who is taxed, and what is taxed tell more about a society than anything else" (Adams 1993:21). The ideal tax system is economically efficient, administratively effective, and politically perceived as equitable. This ambition is problematic everywhere, with developing countries often particularly challenged by the nature of their economies (with an often large agriculture sector and widespread small and informal businesses), administrative inefficiency and corruption, and limited trust in weak state institutions (World Bank 2007).

Douglass North defined the state as "an organization with a comparative advantage in violence, extending over a geographic area whose boundaries are determined by its power to tax constituents" (North 1981:21). Tax systems also reflect their societies. Ideas, interests, and political power structures shape the interpretation of efficiency (whether the tax enhances or diminishes the overall welfare either of those who are taxed or society generally) and equity (whether the tax is fair). ${ }^{14}$ As Schumpeter (1991:100) famously observed: "The fiscal history of a people is above all an essential part of its general history. An enormous influence on the fate of nations emanates from the economic bleeding which the needs of the states necessitates, and from the use to which its results are put. . . The spirit of a people, its cultural level, its social structure . . . all this and more is written in its fiscal history ... He who knows how to listen to its message here discerns the thunder of world history more clearly than anyone else." Taxes are also a critical step in state capacity building - the "Domesday Book Dynamic" of information gathering leads to better policy making, creating a cycle of greater state effectiveness and legitimacy through the taxation apparatus. ${ }^{15}$

\footnotetext{
${ }^{14}$ See, for example, Daunton (2001, 2002) on the United Kingdom; Steinmo (1993) on Sweden, the United Kingdom, and the United States; Lieberman (2003) on South Africa and Brazil; and the IDB (2006) on Latin America.

15 That is, William the Conqueror's efforts to register all land holdings in England in 1086 in the "Domesday Book" for better tax assessment—see McDonald and Snooks (1986).
} 


\subsubsection{Taxation as the politics of the common good}

The leading medieval European theologian Thomas Aquinas asserted that rulers were entitled to tax their subjects only to safeguard the common good. Anything in excess was the equivalent of robbery "wherefore they are bound to restitution just as robbers are." ${ }^{16}$ In many African states, the lack of long-term political commitment to development makes inefficient, high taxation politically profitable for rent-seeking governments (McMillan and Masters 2000). Tax pays for the state's upkeep and survival and for the public goods supplied to its citizens. So the politics of taxation revolve around the role and purpose of the state: are power and the institutions of the state used for the common good, or is tax expropriation for the preservation and narrow interests of elites, to uphold an unjust and unequal status quo?

Tax policies and tax systems arise out of political choices. Effective democratic institutions yield tax systems that follow predictable patterns. The efficiency of taxation depends on the political framework designed by the political settlement and subsequent voting choices shaped by the extent to which elites will contribute to the upkeep of the state and the degree of politically salient divides, such as along ethnolinguistic lines (Hettich and Winer 1999). Effective tax regimes must reflect reality through political bargaining, involving all relevant actors in legislatures, government, and civil society (Witt 2007:59-62).

In medieval England, the political slogan "What touches all requires the approval of all" was widely used to assert political "voice" over tax for the common good by the early 14th century. In 1339, the House of Commons declared that no free man should be assessed for tax or obliged to pay it without Parliament's consent. The year 1340 saw perhaps the most momentous step in fiscal history when Parliament, for the first time, expressly linked its approval of taxation to redress by the executive of political grievances over poor governance. By that time, members of Parliament were already expressing concern over the impact of taxation on rural poverty, worried that tax would force poor farmers off the land, provoke political unrest, and affect workers' incomes (Putnam 1908:98-149). Parliament hoped to use its leverage over tax to tackle corruption, passing the Ordinances of 1311 that required all ministers and judges to certify that they were not guilty of accepting bribes or delaying justice. Taxpayers had come "to regard taxation ... as a charge on communities in the interests of government and the governing class" (Harris 1975:343).

In many developing countries, however, this political evolution (fostered by taxation) of rights and obligations between citizen and state has barely begun. "Recent experiences in Africa and elsewhere make it clear that the preferences of governments often bear little correspondence to any idealization of the public interest.

\footnotetext{
${ }^{16}$ Aquinas, "Summa Theologica"; warfare necessitated taxation, so a "just war" created the moral compulsion to pay taxes.
} 
Rather, governments engage in bureaucratic accumulation and act so as to enhance the wealth and power of those who derive their incomes from the public sector; they also act on behalf of private factions, be they social classes, military cliques, or ethnic groups. They engage in economic redistribution, often from the poor to the rich and at the expense of economic growth" (Bates 1996:17). Power was simply asserted by colonial rulers, with the same mantle adopted at independence by new rulers. As the World Development Report 2006 notes, "citizens have to be willing to pay taxes. Often they are not—as evident in widespread evasion (especially by the rich and informal sectors) and frequent tax protests. These are matters of administrative capacity and of the implicit social and political contract between the state and citizens. Tax protests are typically symptomatic of a lack of perceived link between tax and service delivery. Often the perception is correct-when spending structures are patronage-driven and the quality and responsiveness of service delivery are low. The challenge here is to embed the tax contract within an overall fiscal-social contract on what the state is expected to deliver" (WDR 2006:14-15).

Each country evolves its taxation according to the local interplay of a complex set of competing pressures: political power, economic structure, administrative capacity, political agreement on the size and scale of public services, and access to other sources of revenue (such as aid or debt). A tax system comprises not just the design of its rules (policy), but also (critically in developing countries) its effective administration and determined enforcement. Normative economic analysis assumes that the best tax system is one that is best for the citizens' well-being, or welfare, as citizens judge it-an assumption fraught with difficulties in those developing countries with weak political reflection of citizens' interests and limited information on the welfare impacts of policy options.

The fair and equitable nature of taxation depends on political judgment, including weighing up the social importance of promoting horizontal or vertical equity, as well as the politics of securing legal exemptions and the political legitimacy implied by levels of compliance by different groups in society: "the problem of taxation is more than simply a collective action problem, but a political contest involving struggles over power and definitions of fairness" (Lieberman 2002:89-115, 94). The "inverted U-shape" (Gauthier and Reinnika 2006:373-98) exists in many developing countries, by which medium-size businesses pay a disproportionate share of the tax burden, since large business use political clout to secure exemptions through political influence and the small disappear into informality.

\subsubsection{The culture of compliance: tax morale as the politics of national purpose}

At the center of all taxation is the "fiscal social contract" (Moore 2004) and "culture of compliance" (Torgler and others 2007) that over time develop a "tax morale" (Frey 
2002) and "tax culture" (Edling and Nguyen-Thahn 2006), according to the level of trust existing between people and their government (Bergman 2002) and reinforcing state legitimacy (Englebert 2002). "Tax policy decisions . . . reflect a set of complex social and political interactions between different groups in society in a context established by history and state administrative capacity" (Bird and Zolt 2003:34). So tax-system reform in developing countries reflects general governance problems. It has been suggested that the greater ethnolinguistic fragmentation in Africa undermines tax morale (Li 2007:2675). The TA's attitude toward taxpayers both shapes and reflects the nature of the state and citizenship: a partnership endowed with rights and obligations respected on both sides-or a relationship of arbitrary exploitation, repression, and oppression.

Tax morale (citizens' willingness to pay) is a "psychological contract" with the state, citizens' political motivation to cooperate with the state being shaped by their perception of institutional and political governance quality, through a legitimated political process and trust in public officials and the legal system (Feld and others 2007:102-20). The "fiscal social contract" is therefore a conditional compliance with the authority of the state. "The quality of political institutions has a strong observable effect on tax morale. It is clear that not only the overall index, but also the subfactors of voice and accountability, rule of law, political stability and absence of violence, regulatory quality, and control of corruption exercise a strong influence on tax morale. Moreover, trust in the justice system and the parliament also has a highly significant positive effect on tax morale" (Torgler and others 2007:32). There is a significant correlation between tax morale and the size of the shadow economy. Low tax morale and tax evasion arise not just from the tax burden, but also from distrust in the state, officials' perceived dishonesty, and corruption (Torgler 2007). Post-WWII Japan provides an example: In the immediate aftermath of the war, under U.S. occupation, tax evasion was widespread-in 1948 around 70 percent of people required to file tax returns either failed to fill in the forms correctly and 40 percent completely failed to comply (Usui 2002).

There is, surprisingly, little evidence for the expected utility maximization calculus of tax evasion-namely, that evasion is negatively correlated with the probability of detection and the degree of punishment. Tax morale shows that people have a much more complex relationship with the state than mere utility maximization. Rather, if citizens perceive that their interests (preferences) are properly represented in political institutions and they receive an adequate supply of public goods, their identification with the state and their willingness to pay tax increases. Trust in the state and public officials seems to be a key determinant in maintaining and increasing tax morale and thus taxpayers' willingness to contribute to a public good. On the other hand, in an inefficient state where corruption is rampant, citizens will have little trust in authority and thus will experience a low incentive to cooperate. A more 
encompassing and legitimate state increases citizens' willingness to contribute, yet if the government and the administration hold considerable discretionary power over the allocation of resources, the level of corruption increases. A sustainable tax system is based on a fair tax system and responsive government, achieved through a strong connection between tax payments and the supply of public goods (Bird, MartinezVazquez, and Torgler 2006:283-338).

Tax compliance and informality have traditionally been understood in terms of taxpayer perception of the tax burden weighed against the effectiveness of its enforcement and the "value for money" of services received. But this is clearly an inadequate explanation; states with the highest tax burden (that is, OECD countries) also have low penalties and limited audits, yet enjoy a high level of compliance. Increased enforcement will generally lead to increased compliance but, in some cases, compliance levels are higher than warranted by any increase in enforcement.

Recent studies have shown that this "quasi-voluntary" compliance is the product of "tax morale," that is, taxpayers' assessment of the overall quality of governance. This has two dimensions:

- The individual taxpayer's assessment of personal benefit from the "fiscal social contract" - the exchange of acceptance of the state in return for essential public goods (such as security) and core services (such as infrastructure, health, and education)

- Taxpayer perception of the legitimacy of the state, a mix of political acceptance of state authority, fairness and effectiveness of state institutions, and trust in public institutions and officials.

Overall compliance is shaped by the enforcement capability of the tax authority, which has two dimensions:

- Taxpayer acceptance of enforcement as a legitimate and effective exercise of state power

- Perception of the fairness and effectiveness of the tax authority based on intuition of the extent of other taxpayers' levels of compliance.

Excessive discretionary power makes TA neither credible nor effective. Taxpayercitizens' tax morale is crowded out, especially where corruption is systemic, the government budget lacks transparency and accountability, and rule of law is weak. Ineffectual checks on corruption further reduce the incentive to pay taxes.

Political context is critical, as shown by comparing Brazil, South Africa, and Botswana. Brazil and South Africa had racial and regional divides in the late 19th century. South Africa's institutionalized apartheid created a racial political solidarity that contributed to the development of a highly progressive and efficient tax system. 
TABLE 2.1 Tax reform diagnostic tool: evaluate compliance levels from "tax morale"

\begin{tabular}{|r|c|c|c|}
\hline & High & $\begin{array}{c}\text { Conditional } \\
\text { compliance }\end{array}$ & $\begin{array}{c}\text { High voluntary } \\
\text { compliance }\end{array}$ \\
\hline $\begin{array}{r}\text { Taxpayer perception } \\
\text { of utility of public } \\
\text { goods and services }\end{array}$ & Low & $\begin{array}{c}\text { No voluntary } \\
\text { compliance }\end{array}$ & $\begin{array}{c}\text { Conditional } \\
\text { compliance }\end{array}$ \\
\cline { 2 - 4 } & & Low & High \\
\hline & Taxpayers' perception of state legitimacy \\
\hline
\end{tabular}

Source: Everest-Phillips 2008.

In Brazil, the federal constitution made a progressive tax system much more difficult, with an "adversarial" approach to taxation "in which upper groups are consistently at odds with each other and the state over the allocation of the tax burden," as in the cooperative tax system of post-apartheid South Africa (Lieberman 2005). By comparison, compliance has been consistently higher in Botswana than in South Africa, because of the stronger "sense of national purpose" and trust in the government in Botswana (Cummings and others 2006). Poor tax morale resulting from a decline in the quality of governance threatens to start a vicious cycle of increasingly coercive enforcement, further worsening compliance (Alm, Sanchez, and De Juan 1995:725-37 and Borck 2004).

\subsubsection{Visible and invisible/direct and indirect taxation}

Different taxes have different political salience. Lieberman (2002:94) notes: "significant levels of tax collections imply that a sufficient share of the citizenry has been persuaded to see beyond narrow interests, and to contribute to the collective welfare through tax payment." Weyland (1998), for instance, measures the rise and decline of Brazil's "developmental state" through taxation revenues. Theory suggests that the

TABLE 2.2 Tax reform diagnostic tool: how governance shapes tax compliance

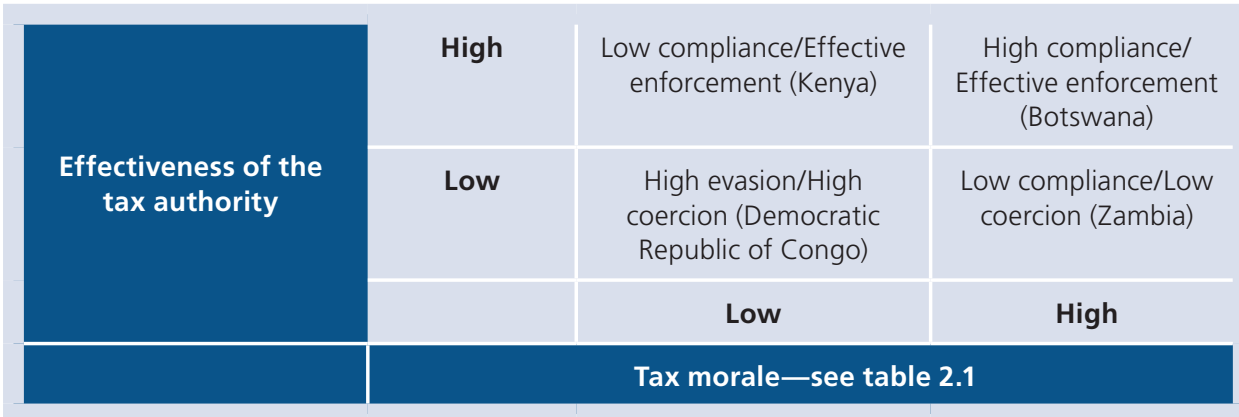

Source: Everest-Phillips 2008. 
more "visible" a tax, the more the electorate will be concerned about its effect, and so more likely to mobilize politically. The most visible taxation is direct, personal taxation-also the most politically explosive as the discussion on poll and hut tax revolts suggests. U.S. and Japanese scholars have sought to argue that European-style welfare states are run on indirect and therefore less visible taxation, so supposedly succeed not because social welfare is actively desired and legitimizes the state, but rather because indirect taxes are invisible and so do not provoke political resistance (Prasad 2005:357-407, 362). Pay-as-you-earn income tax may be less visible because the tax is removed before pay is received (Buchanan 1999).

Others, however, suggest that the political salience of visibility and different types of taxation is not so clear-cut. Moore (2007) notes, in developing countries, a shift from indirect trade taxes to more direct taxes, and widespread introduction of taxes on goods and services such as VAT. This makes taxes more visible, and therefore more likely to mobilize taxpayers politically, because VAT, although an indirect tax, imposes a continuing, visible burden on small and medium-size businesses (Moore 2007). A comparison of collective action in the Aztec empire, England under Edward III, and Renaissance Venice finds that where a state's fiscal base was domestic revenue rather than long-distance trade (or tributes, slave labor, and rents on ruler-owned lands), commoners were allowed greater "voice" and, in turn, placed heavier equity demands on rulers (Fargher and others 2007:848-82).

Visibility probably reflects the broader political legitimacy as much as the perception and impact of any particular tax. An indirect tax such as VAT supposedly generates comparatively little political conflict because it is "invisible" to taxpayers (Kato 2003; Wilensky 2002). But the degree of "visibility" depends on many practical as well as political factors, from whether it is separately identified in prices to whether it is actually paid and collected. The introduction of VAT in Ghana, for example, generated political hostility resulting in widespread rioting. Parliament passed the VAT Act in December 1994, although political support from government supporters for the reform was half-hearted, and it provided the opposition with a powerful rallying point. When VAT became operational in Ghana on March 1, 1995, prices of goods and services immediately shot up. The Alliance for Change (AFC) opposition organized a mass demonstration in May 1995, during which four people were killed, forcing the government to abandon VAT in June 1995. But this failure was the result of inadequate political management of the reform process. VAT was pushed through without adequate consultation with business associations and other key stakeholders; at a bad time (implemented immediately after the budget had already increased prices on basics); and without adequate taxpayer education. In addition, many exempt items, such as food, were wrongly taxed. After proper political debate and public education, the VAT was successfully reintroduced in $1998 .{ }^{17}$

${ }^{17}$ Based on Terkper (1996:1801-16); IMF (2001). 
2.3.3.1 Presumptive taxes. These are visible and, while they may raise only limited revenues, can be important for extending the social contract into the informal sector, which is often the biggest part of developing countries' economies and populations (and electorates). Presumptive taxation, however, creates an inevitable trade-off between efficiency and equity, which may drive presumptive taxation away from its initial objectives of simplicity and lower compliance and enforcement costs. Citizens must pay taxes on a political judgment of their economic capacity, and all taxpayers must meet their tax obligation. Presumptive taxation is therefore a compromise among ability to pay, administrative efficiency, and the rights of citizens, but is often the only levy effectively imposed on the large informal sector (Schneider and Klingmaier 2004). Auriol and Walters (2005) suggest, therefore, that a bad tax on a "good" base may be a good idea. ${ }^{18}$ Presumptive taxation is, as a result, widely used around the developing world, with taxable income estimated on the basis of different factors applied to specific types of taxpayers on aggregate indicators such as industry and region or external indicators of income (Bird and Zolt 2005; Bird and Wallace 2003; Chipeta 2002; Sadka and Tanzi 1993). But success is patchy: In Ghana, for instance, presumptive taxation has existed for over 25 years but still has failed to be effective in reaching much of the informal sector, has done little to raise revenues, and has had marginal impact on promoting formality (Terkper 1995; Appiah-Kubi 2003). As Bird and Wallace (2003:20) warn: "the political economy of presumptive systems almost guarantees that the tax burdens enjoyed by those in such regimes are sufficiently favorable to make them an attractive place to stay and provide no incentive to ever graduate." The result of a "simplified" tax system intended to entice people from the informal sector into the formal sector may instead encourage the formal sector to hide in the simplified system, creating a barrier to firms moving to the normal tax system.

2.3.3.2 Earmarking (hypothecation). Linking specific revenue sources to specific expenditures can create a contract for action, increasing the political costs to future governments of breaching the contract (Cremer, Estache, and Seabright 1995). ${ }^{19}$ This linkage reflects the state of tax morale. Earmarking was widespread in Britain in the early 19th century but was replaced mid-century by the "Gladstonian" approach to public finance, of a consolidated budget with no earmarking (Daunton 2001). The aim then was to contain public expenditures to restore public trust in the neutrality of public finances, given the perception that hypothecated revenues were misused by the political elite, and especially to pay for overseas military adventures. So whether earmarking increases or reduces public trust depends largely upon the political context

\footnotetext{
${ }^{18}$ In addition, presumptive taxes may sometimes serve as a useful backstop for taxes in the formal sector. For example, Mexico imposes a minimum tax on the gross assets of a business: If the profits reported for tax purposes exceed a certain minimum rate of return on the assets, the profits tax is applied as usual, but if the reported rate of profits is below the minimal return, the business is instead subject to a tax based on assets.
} 
for tax morale. Buchanan (1963) revived Wicksell's argument for directly connecting tax to expenditure in order to secure political consent for a tax increase and to provide people with the public services they really want (that is, are expressly willing to pay for). As a result, many taxes are given politically positive names like the Education Tax, the Employer Health Tax, the Hospital Tax, and the Security Levy. Perception matters in politics. A good name may do as much to help a tax as a bad one can do to kill it. ${ }^{20}$ Such an explicit "fiscal social contract" may make political and economic sense by explicitly emphasizing the "Wicksellian connection" between revenues and expenditures, but can also be a political sleight of hand-and fungible. Politicians see earmarking as a means of reducing taxpayer resistance to higher taxes; taxpayers recognize the potential for greater accountability; but public finance experts almost unanimously oppose the constraints that arise from earmarking.

\subsection{Conclusion}

Considering the political economy implications of tax simplification is essential to the success of any intervention to improve the investment climate. Thus far, little attention has been paid to this issue by policy makers, although its importance has always been felt. It is hoped that these considerations inform technical assistance of tax reform.

The next chapter builds the foundation for tax simplification by first measuring the overall burden (including the administrative burden), then identifying several steps to reduce this burden.

\section{Further Guidance}

- Max Everest-Phillips (ed.). 2008. Political Economy of Taxation in Developing Countries: Challenges to Practitioners. World Bank Group-DFID.

\footnotetext{
${ }^{19}$ Earmarking may provide both voters a way to pin down politicians about whom they are uncertain and politicians a way to "signal" their concerns to voters in a credible way; see Brett and Keen (2000).

${ }^{20}$ Graetz and Shapiro (2005) stress that the label "death tax" was decisive in the repeal of the U.S. estate tax. Similarly the label "poll tax" killed off Thatcher's "Community Charge" in the United Kingdom.
} 


\section{Chapter 3: Measuring the Burden of Business Taxes}

\section{CHECKLIST OF GOOD PRACTICES}

$\checkmark$ The government calculates the overall tax burden on a regular basis

$\checkmark$ Governments use both average and marginal effective tax rates on business to benchmark the overall tax burden

$\checkmark$ Cost-of-compliance surveys are conducted regularly to monitor the progress of tax simplification

$\checkmark$ Such surveys are conducted by independent, preferably nongovernment, agencies to ensure truthful responses from businesses

$\checkmark$ Tax administrators regularly prepare process maps to remove redundancies

$\checkmark$ The government regularly conducts an inventory the number and burden of all tax and quasi-tax instruments

Tax policies and their administration should be subject to systematic monitoring and evaluation in order to ascertain which processes are working as envisioned and which may be falling short of expectations. Similarly, tax reforms meant to improve the business environment should be subject to systematic monitoring and evaluation to ensure they remain on track toward their objectives.

The benefits of business tax reforms that improve the business environment include

- More businesses registered to be taxed;

- More medium-term revenue;

- Lower tax-compliance costs.

As with most public policies, monitoring and evaluating tax policies is a challenge because the indicators can be affected by a large number of exogenous influences. It is usually not possible to conduct a "controlled" experiment to determine the impact of specific policies on key impact variables. Nevertheless, it is possible to collect information that indicates whether a policy is helping to achieve its desired 
results or not. Such information should be available to a well-functioning tax administration, supplemented by that from outside sources.

Given the many trade-offs involved in any policy reform, the reform strategy itself needs clearly articulated objectives and priorities based on objectively verifiable indicators of progress. For example, a reform may be designed with the object of improving incentives for business growth, subject to maintaining medium-term revenue from business taxes.

The purpose of this chapter is to provide guidelines for the monitoring and evaluation of business tax policies and their reform. The next section provides an overview of how taxes affect the business environment in a country. This is followed by a discussion of tools for measuring and evaluating the impact of specific tax elements and their administration. The final section proposes a framework for monitoring and evaluation.

\subsection{How Taxes Affect the Business Environment}

The major way that taxes shape the business environment is by affecting business costs. Most obviously, taxes paid by firms reduce net profit. Taxes also add (indirectly) to business costs by imposing compliance costs and by reducing the predictability of business costs when tax regimes change. In fact, five of the seven "canons of taxation" listed by the Institute for Fiscal Studies (IFS) seek to minimize the negative consequences of bad tax policy and administration on taxpayers:

- The timing and amount to be paid must be certain to the payer.

- The means and timing of payment must be convenient to the payer.

- Taxes should be levied according to ability to pay.

- A tax should be compatible with foreign tax systems.

- Tax should automatically adjust to changes in the rate of inflation. ${ }^{1}$

To these canons must be added a cross-cutting requirement that tax administration (TA) corruption (and its costs) be minimized or, even better, eliminated.

Some elaboration on these canons is given in the following subsections.

\footnotetext{
1 See the biz/ed Web site of the Institute for Fiscal Studies (www.bized.co.uk). The first three of these canons (or maxims) are attributed to Adam Smith's Wealth of Nations, published in 1776. The other canons listed on the Web site are "The cost of collection must be low relative to the yield" (also attributed to Smith) and "A tax must not hinder efficiency or should involve the least loss of efficiency."
} 


\subsubsection{Tax level}

This directly affects business costs. Most taxes are levied periodically (for example, annually) and so consistently affect business operating costs and, thus, profitability. ${ }^{2}$

The important metrics used to measure the tax burden are:

- Effective tax return on investment (ROI)

- Effective tax rate per pretax dollar of output.

For tax evaluation, the most important scaling variable is the return on investment (ROI). The impact of taxes and related levies on the ROI is also a measure of their impact on business activity. (In the next section, three different measures of the impact of the effective tax $R O I$ will be discussed.) A second indicator is the marginal impact per unit of good or service produced by a business. This is useful in examining the indirect impact of taxes on other businesses, on inputs such as labor and capital, and on consumers. The effective tax per pretax dollar of output is a useful measure for this purpose. ${ }^{3}$ It should be noted that where businesses rely on thirdparty lenders, owners place greater emphasis on measures and performance ratios monitored by their lenders. In many instances, the continued availability of credit is dependent on meeting certain targets for effective tax rates and ROI, as well as on meeting other asset-based tests.

Problems inherent in measuring effective tax rates include the fact that:

- Multiple taxes interact with each other through (i) affecting each other's basis and (ii) cascading.

- The feedback effects of the true tax burden differ from those of the statutory tax burden as taxpayers change their behavior in response to promised taxation.

- Inflation affects the tax burden in different ways, as discussed below.

The accurate measurement of effective tax rates is usually complicated by the existence of multiple levies and (partial and general equilibrium) feedback effects from other sectors of the economy. Multiple levies-including the value-added tax (VAT), the corporation tax, excises, import duties, and property taxes-interact with each other to make the resulting effective tax rate only imperfectly correlated with the total revenue from these levies. In particular, cascading (taxes on taxes) can make the impact of multiple levies greater than if the same tax revenue were to be collected through a single levy. Feedback effects also cause the true tax burden or economic tax

\footnotetext{
2 Some levies, such as license fees and stamp duties, also significantly impact business start-up costs.

3 Effective tax rates can either be average or marginal rates, as discussed further in this chapter.
} 
incidence to differ from what tax rates would suggest, since business, labor, capital owners, and households adjust their behavior (legally or illegally) to reduce their tax burden. This puts part of the burden on other members of the economy legally liable to pay the tax, often through changes in the price or availability of goods and services on which the tax is levied. As those affected respond to taxation, their behavioral changes trigger further adjustments by yet other affected members - and so on, ultimately affecting the economic and cost environment of the business on which the tax was initially levied. So, estimated effective tax rates are only first approximations that (i) may be greater or less than actual effective rates and (ii) may differ across businesses.

Because of both feedback effects and multiple levies, tax rates set in accordance with some measure of ability to pay (the third canon listed) may not always meet their pro-business objectives. For example, such taxes may cause businesses to shelve plans to engage in a given activity or otherwise "kill off" businesses. Or they may not help loss-making businesses, which typically end up paying more taxes than they have the ability to pay due to limited or imperfect loss-offset provisions.

How imperfect tax codes impact foreign business activity is both of growing importance and difficult to measure. Such codes also impact tax liability in the presence of significant inflation. These issues are the focus of the fourth and fifth canons listed.

Taxable transactions involving two or more jurisdictions are at risk of being subject to double taxation, with an increased compliance burden for the businesses involved. These negative impacts can be mitigated through relevant treaties with partner countries and also through unilateral tax-sparing clauses. Appropriate income, cost, and revenue recognition rules are also needed. On the other hand, tax provisions to reduce international tax avoidance are needed to protect revenues, particularly where tax havens are used to channel transactions ${ }^{4}$ and where corporations supply goods and services to related companies.

Inflation causes the real value of revenues and the business costs to differ whenever they are incurred at different points in time or when tax dues are assessed with a lag. For example, an acquired asset, subsequently sold at a higher price, will result in a capital gain in the absence of inflation. By contrast, the same scenario can result in capital loss when inflation is sufficiently high. In theory, inflation effects can be avoided through the perfect indexation of tax dues. In practice, however, perfect indexation is hard to achieve, especially if inflation is not anticipated. ${ }^{5}$

Even in the absence of inflation, differences in transaction and tax timing can impact the present value of tax dues, when account is taken of the time value of money. This is a pervasive problem across tax systems; it affects business costs in almost all

\footnotetext{
4 For a further discussion of these issues, see Das-Gupta (2008) and McLure (2006).

5 Inflation also has a potential negative effect on real tax revenue in the absence of perfect indexation. See Tanzi (1977) for the pioneering analysis of this issue.
} 
countries. ${ }^{6}$ Particularly in the incomplete and fragmented capital markets of most developing countries, various businesses and the government place different values on the time value of money.

The tax level should be distinguished from the total impact of taxes and tax obligations on businesses. The total impact will also reflect the costs of complying (and not complying) with tax obligations and the impact of corruption, including bribes. These considerations are reflected in the first two canons listed. Compliance costs can add up to several hundred percent of effective taxes, in some cases. These will be discussed further. ${ }^{7}$

The tax burden is also influenced by the general economic environment in a number of ways. One is the interaction between credit markets and the timing of taxes on business cash flows. For example, if taxes are due before the proceeds from which to pay taxes are received, and if bank credit or credit from other sources is not available or is available only at high interest, this may affect the survival or profitability of an otherwise viable business. This is also a consideration reflected in the second and third canons.

The impact of taxes on business is not restricted to their level alone. The inherent business risk of taxes also affects the business environment and expected business costs (see the first canon of taxation). Enhanced risk, in turn, makes it difficult for businesses to plan their activities, particularly in relation to cash flow and long-term capital investments. Tax-related risk is particularly dangerous in at least five scenarios:

- When a business is required to pay taxes on the basis of estimated tax liability before the actual tax liability is known (as in some advance tax payment or tax withholding regimes). This can affect cash-flow planning and cash-holding costs. In some instances, it can also increase the associated compliance costs when documentation is required to support both the estimated tax calculation and the final one. As well, businesses could face an additional cost if interest is levied on any shortfall between estimated versus actual tax. Some businesses guard against this by "overpaying" the estimated tax, with the result that they must claim the excess back as a refund, and suffer the compliance and cash-flow consequences of doing so.

- When there are unexpected delays in assessing taxes due

\footnotetext{
6 The impact can raise business costs (for example, when taxes are withheld) or lower such costs (for example, when there is a lag between incurring a tax liability and remitting taxes to the government treasury).

7 For a review of compliance cost studies and estimates, see Evans (2003). A business may have a low effective tax rate by making use of tax concessions, but its compliance costs may still be similar in magnitude to other firms. This implies compliance costs that are a multiple of the effective tax rate. It should also be noted that for large businesses with tax-withholding obligations, compliance costs can actually be negative.
} 
- When tax dues are themselves uncertain because of complex and ambiguous tax laws that can lead to disputes and differences in interpretation. In this case, private enterprise is inhibited and, in extreme cases, business entry deterred altogether.

- When there are unanticipated changes in tax provisions after a business activity has commenced. ${ }^{8}$ These can be mitigated, to an extent, by appropriate "grandfathering" clauses for existing business that are adversely affected.

- When there is widespread corruption and extortion, and/or the behavior of tax officials is relatively unpredictable ${ }^{10}$

- When taxes are introduced retroactively.

\subsubsection{Tax-compliance costs ${ }^{11}$}

No widely accepted definition of tax-compliance costs exists. One approach evident in the literature is to define tax-compliance costs as all tax-related costs incurred by the private sector other than the actual taxes paid to the government, either on its own account or on behalf of others. ${ }^{12}$ From this perspective, tax-compliance costs include those costs borne by taxpayers in both complying with tax obligations and not complying (for example, when avoiding or evading taxes). These costs also include both the legal and illegal costs incurred, as when bribes are paid to tax officials. ${ }^{13}$ Compliance costs may include those incurred by third parties, such as banks, responsible for receiving tax payments on behalf of the treasury or tax preparers if they are required to register with the tax authorities. Another example is that of private sector businesses required to file reports on their customers or suppliers (who may be potential taxpayers) even if the businesses make no tax payments.

For tax-paying businesses, core legal cost-compliance costs include time costs (such as time spent for maintaining books and receipts), cash outlays related to meeting tax obligations such as postage, purchase of tax-related publications or software, and payments made to others (such as tax professionals). For businesses in which owners themselves do not personally engage in tax-compliance activities-and so have no

\footnotetext{
8 Attempts to assess the impact of tax complexity and also tax stability on the costs of Indian business are reported in Das-Gupta (2006).

9 Both complex tax codes and unanticipated tax law changes can also lead to unanticipated windfall business profits.

${ }^{10}$ The World Bank's World Business Environment Survey (WBES) attempted to assess the importance of unpredictable corruption on business costs. See, for example, Batra, Kaufmann, and Stone (2002).

11 The discussion here and in section 3 draws on Chattopadhyay and Das-Gupta (2002, 2002a) and on World Bank, Foreign Investment Advisory Service (FIAS) (2007), Appendix B.

12 The Doing Business indicators discussed refer to these as taxes borne and taxes collected.

${ }^{13}$ Bribes paid will not be a part of total private costs since they are a transfer from one nongovernment entity to another. But they may make up a substantial component of individual costs. In countries where bribes are substantial, therefore, the sum of compliance costs incurred by businesses may exceed total private sector compliance costs.
} 


\section{BOX 3.1 FIAS Tax-Compliance Costs and Perception Surveys}

FIAS has completed tax-compliance cost surveys in three countries. It concluded that:

- South Africa had a relatively moderate tax-compliance burden and a relatively efficient and transparent business tax regime.

- Yemen had a more onerous tax-compliance burden and an opaque and old-fashioned business tax regime.

- Ukraine had a heavy tax-compliance burden and a complex business tax regime.

In South Africa, the national treasury has used tax-compliance cost surveys (a set of three-one of professional tax practitioners, one of SMEs registered for tax, and one of informal firms) as "ammunition" to help push through reforms intended to reduce compliance costs for small businesses and to encourage the formalization of informal firms. The survey data helped document the need to increase the threshold for mandatory VAT registration and to develop an optional, simplified "turnover tax" regime for small businesses that would enable entrepreneurs with only minimal bookkeeping skills to manage their own tax returns. In Yemen, survey data are being used to help define new categories of businesses eligible for a very simple "patent" or local tax regime (intended for micro-enterprises, which are more likely to lack bookkeeping capacity), for a simplified turnover tax regime (intended for small businesses, most of which already maintain simple books), and for the regular tax regime (intended primarily for medium and large businesses, which will be expected to keep proper accounts and to file taxes on the basis of selfassessment). In Ukraine, the FIAS survey documents quite onerous tax-compliance costs for most legal entities and is expected to be used by the World Bank's tax administration-reform project to help design and push through a major overhaul of business taxes, including, for example, the consolidation of various payroll taxes and a reduction of the burden of tax inspections.

The table below compares the time burden of complying with the principal taxes, in hours per year, based on a representative sample of business taxpayers and focusing on data for medium-size businesses.

\section{TIME (HOURS PER YEAR) REQUIRED BY MEDIUM-SIZE BUSINESS TO COMPLY WITH BASIC TAXES}

\begin{tabular}{|l|c|c|c|}
\hline & South Africa & Yemen & Ukraine \\
\hline Corporate income tax & 42 & 229 & 510 \\
\hline Payroll taxes & 18 & 155 & 640 \\
\hline VAT & 45 & 365 & 1,240 \\
\hline Total & 105 & 649 & 2,400 \\
\hline
\end{tabular}

Source: Coolidge, Jackie (2009), Tax Compliance Cost Surveys (FIAS). World Bank.

direct time costs-compliance costs can be classified as in-house personnel costs, other in-house costs, and external costs. External costs include the costs of retaining tax, accounting, and legal professionals and also, possibly, illegal costs such as bribes and gifts to government officials. Inhouse tax-compliance costs may be incurred both by specialized tax departments and other departments. 
The major legal activities associated with tax compliance include maintaining accounting data; filing required tax returns; obtaining taxpayer identification numbers, clearances, and permissions where required by law; planning a tax return strategy to reduce tax liability; tax audits, appeals, and dispute proceedings; exacting interest on late tax payments; and, possibly, tax penalties and prosecution proceedings. Also included are the costs of discharging statutory tax-withholding obligations.

Besides direct costs, businesses may also incur indirect costs, as when tax refunds are delayed, thus reducing the present value of the net cash flow of the business. ${ }^{14}$

A distinction must be made between businesses' gross and net compliance costs. Net compliance costs are the difference between gross compliance costs and the value of benefits from tax-compliance activities. The major benefit is from the augmented cash flow that arises when taxes become liable or are collected from others when taxes are withheld. Benefits can also arise from better recordkeeping and improved management control, though these may be hard to quantify. Tax-deductible expenditure is also relevant when computing net individual and private sector costs. For large companies in some jurisdictions, a survey conducted by Evans (2003) reports negative tax-compliance costs. ${ }^{15}$

Compliance costs also include less easily quantifiable elements, such as the costs of ambiguous guidelines or rates and what are generally known as psychological costs.

\subsection{Monitoring and Evaluation Tools}

There are a variety of monitoring and evaluation tools used to assess the impact of taxes on business and private investment. Important sources include:

- Data and information available from revenue authorities

- Effective tax-rate analysis

- Published international indicators

- Business surveys, including compliance-cost studies, time-and-motion studies, and expert assessments.

These sources will be briefly reviewed.

\footnotetext{
${ }^{14}$ Overpayment of taxes as insurance against tax noncompliance proceedings has also been reported by some studies.

${ }^{15}$ A distinction should be made between private compliance costs and social costs, or the costs to society of compliance with tax obligations. For example, even if a business has negative net compliance costs, the real resources used in complying remain a cost to society. Social costs are not considered here.
} 


\subsubsection{Data and information available from revenue authorities}

Reasonably well-functioning revenue authorities should have a great deal of information available that is necessary for the monitoring and evaluation of the business tax environment. In many developing and transitional economies, however, relevant data are unlikely to have been collected or analyzed on a systematic basis. The availability and accuracy of information are linked to the existence of formal institutional arrangements to promote accountability and monitor administrative performance, such as competent independent audit institutions and effective legislative or presidential oversight.

Under weak monitoring and oversight regimes, data provided by tax administrators may be incomplete or misleading, particularly if such data threaten to reflect negatively on administrative performance. If so, the data may need to be cross-checked against other information sources (such as business surveys and taxpayer feedback forms).

Data that should be most easily available include the records of each taxpayer and his or her tax payments. These records should be available in the form of basic taxpayer information documents, such as taxpayer master files (or an equivalent taxpayer and tax withholder's database) and current taxpayer accounts (or an equivalent tax payment database). Such data should ideally include:

(a) Annual information on (i) the number of business taxpayers registered and deregistered and (ii) taxes paid or withheld by each business taxpayer, classified by:

- Legal form

- Turnover or some other indicator of business size used to group taxpayers

- Types of taxes paid or withheld

- Geographical jurisdiction

- Type of activity or sector.

Supplementary data from tax assessment and administration activity records that should also be available under most TAs include data on filing and the assessed or self-reported taxes due, including:

(b) For different taxes, annual data on the number of business taxpayers who:

- Have filed on time

- Have filed late

- Are exempt from filing requirements

- Have registered and are required to file returns but have not

- Have instituted liquidation measures

- None of the above. 
(c) Similar annual information on business taxpayers who are required to withhold taxes and file withholding returns, if these are separate from taxes due from their own business activities

(d) Turnover, taxable profits, and other data on each taxpayer's tax base, together with different taxes assessed or self-assessed

(e) Annual data on the processing of tax registrations, returns, queries, appeals (by taxpayers and tax administrators), grievances, noncompliance proceedings, tax raids, and tax investigations

Essential information for the assessment of business environment and compliance costs that may not be readily available include the time taken for each of these tax activities. This information will typically be available only under more sophisticated TAs. Possibilities include the average time required to:

- Process a registration or issue a tax identification number

- Process returns and assess taxes and related levies

- Effect the payment of a refund

- Respond to a query or attend to a grievance

- Handle tax appeals or tax disputes via different appeals and judicial channels

- Handle tax investigations, penalty proceedings, or prosecutions

Quality indicators for activities—besides time taken—may also be made available with some effort. Possibilities include:

- The proportion of tax assessments disputed and the revenue involved

- Outcome - in numbers and revenue amount —of appeals and other tax disputes and noncompliance proceedings. In particular, the proportion of cases against the TA (or sent for further action by the TA before adjudication) will reflect the extent to which costs are imposed on the taxpayer without any revenue benefit.

- Independent taxpayer feedback on query responses or grievances redressed. Besides the activities mentioned, information on audits and other inspections is of particular importance. Such information could include:

- The percentage of business taxpayers subject to inspections or audits of different types

- The number of visits to premises or tax offices and their average duration

- The outcome of audits in terms of both disputed and undisputed additional revenue assessed, the number of cases, and the revenue impact. 


\subsubsection{Effective tax rate analyses}

How to analyze businesses' effective fiscal tax burden has been outlined in the previous section and is the subject of a large body of literature. ${ }^{16}$ Effective tax rate measures capture the combined effect of most relevant taxes on a specific, defined business "case" or input category. That the effective tax rates must be computed for a business with defined characteristics is both a strength and a limitation. The strength is that it permits comparison across time periods, jurisdictions, and tax regimes. The weakness is that it does not reflect the tax burden of different types of businesses or economic activities, other than those for which it is computed. It should be noted that effective tax rate measures do not generally reflect tax-compliance costs, though in principle this is possible. ${ }^{17}$

Effective tax rate measures can be used to assess the impact of tax policy reforms, including changes in statutory tax rates and other key tax parameters (such as changes in rules governing depreciation rates or loss carry-forward) or even the introduction or removal of particular levies. They can also take account of one-off tax provisions, including special surcharges and (possibly) tax holidays, as well as imperfect indexation for inflation. Effective tax rates also take into account the impact of different financing patterns of firm debt, equity, and retained earnings. While unavoidable, this last property partly limits comparison across businesses with different financing patterns.

Effective tax rates can also be used to assess the bias in favor of or against different inputs in planning expanded business activity. For example, effective tax rates can be calculated for expanding the number of people employed or acquiring additional capital (or some combination of these variables). ${ }^{18}$ Tax biases against different inputs are of independent interest in assessing the impact of taxes on business.

Another major use of effective tax rate analysis, as mentioned, is to compare the tax burden of different groups of interest. For example, businesses analyzed could be grouped by region or country, economic activity or sector, or size. Such analysis can also be used to track the impact of tax changes on defined businesses across time.

(a) The marginal effective tax rate (METR) focuses on the impact of business taxes on marginal investment decisions, and thus provides a measure of how a business tax regime may affect investment trends in the country, its competitiveness vis-à-vis alternative investment locations, or the relative tax on

\footnotetext{
${ }^{16}$ Useful references are McKenzie, Mansour, and Brûlé (1998), Chen (2000), Mintz (2000), Devereux and Griffith (2003) and Klemm (2008). See also Shah (1995). Of these, Chen and Mintz are relatively nontechnical. McKenzie, Mansour, and Brûlé (1998) and Klemm (2008) present actual computation formulae.

${ }^{17}$ For example, interest lost due to delayed refunds could be put into the model to indicate an additional cost to business due to the tax.

${ }^{18}$ See, for example, McKenzie, Mansour, and Brûlé (1998).
} 
(or subsidy of) different sectors in the economy and different types of assets. See Appendix 3A for an example of calculation of METRs.

The general procedure for measuring the METR is first to assess the marginal cost of production for a firm with defined characteristics, without accounting for taxes, and then to compare the difference in the marginal cost with taxes factored in. This approach can be turned into a measure of the impact of taxes on the ROI by considering (i) the additional tax due on an additional dollar of investment or (ii) the proportionate tax wedge between the pretax and posttax ROI. The METR on additional investment indicates the tax burden an investor will face when undertaking an additional investment project.

(b) The average effective tax rate (AETR) is a more general measure of the tax burden on a particular type of business. It is a useful indicator of how the tax regime may be influencing (i) the decisions of new business start-ups, (ii) overall capital/labor ratios, and (iii) general investment trends. There are two distinct AETR concepts. The first is an ex post measure of the burden of taxes actually borne by a particular business for a defined period (Chen 2000). As such, it is of limited use in analyzing future tax burdens. The second AETR concept is forward-looking. ${ }^{19}$ As with the ex post AETR, it examines the tax-burden effect of a business's total investment, not just a small increase in investment like the METR.

In particular, it is the appropriate measure to use when evaluating mutually exclusive business location decisions (in contrast, the METR is useful for planning the optimal size of an investment). ${ }^{20}$ The average effective tax rates for four Nigerian states were calculated using a survey. ${ }^{21}$ The rates show considerable variation among the sectors and across states. The AETRs are quite high due to the indirect tax (VAT) that is paid by corporations. In the case of Cross River, in which commercial agriculture is an important sector, there are several indirect taxes on the agricultural sector. For more, see figure 3.1.

\subsubsection{Published international indicators}

A key consideration in attracting and retaining business investment is comparing the tax burden with that of potential competitor countries. Given the growing globalization of business, a number of organizations have recently begun to examine relative

\footnotetext{
${ }^{19}$ Devereux and Griffith (2003) develop this measure to study the location decisions of multinationals. They show that the AETR, which allows for differential taxation of economic rents and not just cost differences, is a weighted average of the METR and the statutory tax rate applicable to economic rents. Klemm (2008) extends their analysis to allow for varying tax rates arising, for example, from tax holidays.

${ }^{20}$ As can be expected, the methodology for computing effective tax rates in different contexts is evolving. For an example of a recent advance see Chirinko and Schaller (2008).

${ }^{21}$ Nigeria: Sector Study of Effective Tax burden (AETR), FIAS (2008).
} 
FIGURE 3.1 Average effective tax rates in four Nigerian states

\section{Cross River: AETR}

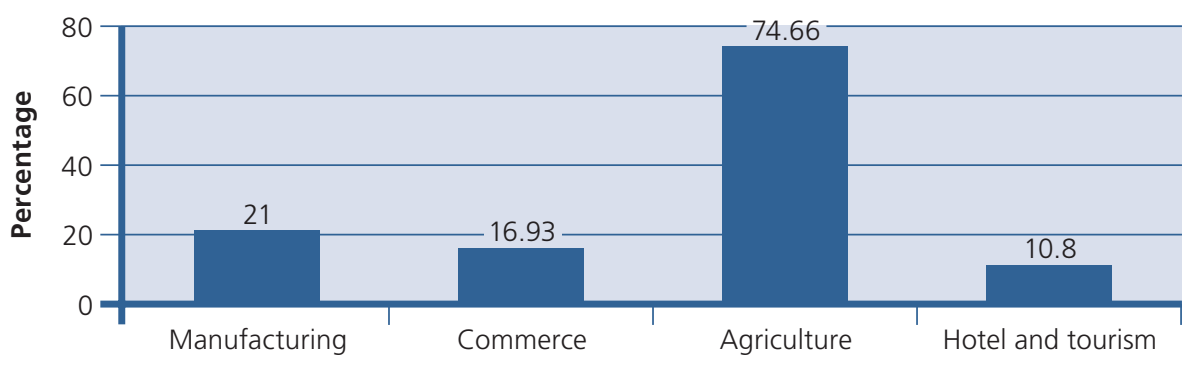

Kaduna: AETR

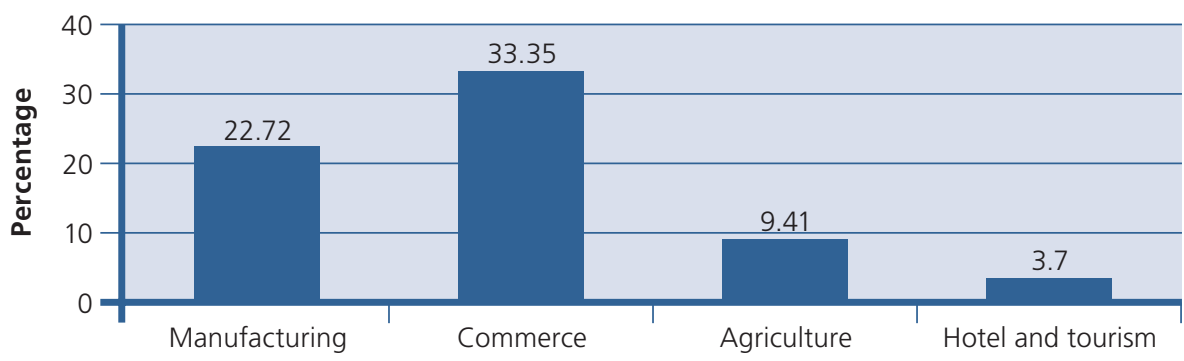

Kano: AETR

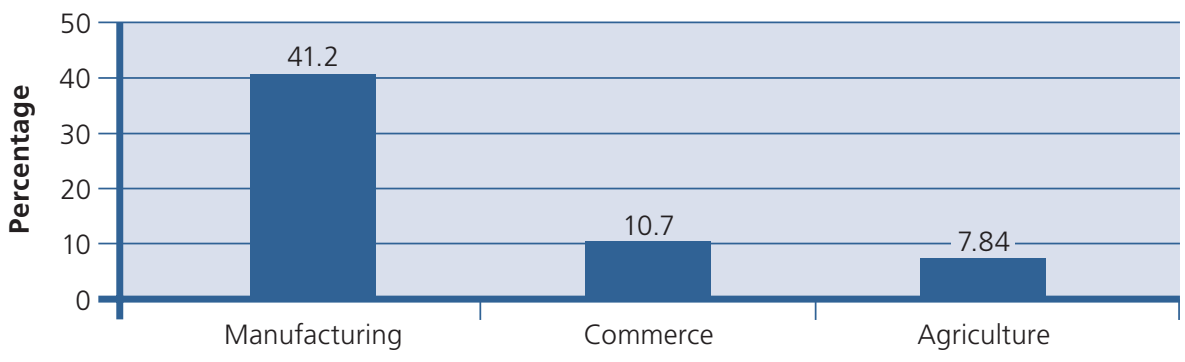

Lagos: AETR

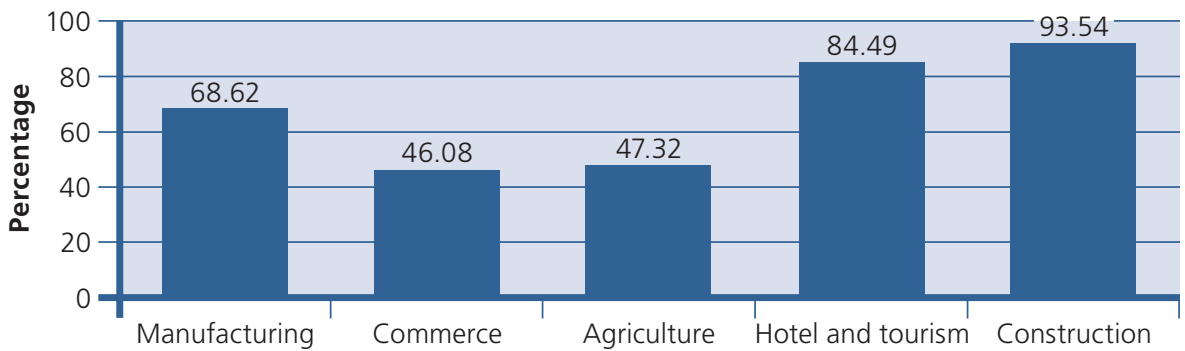

Source: FIAS 2008. 


\section{BOX 3.2 METR versus AETR}

The METR must be differentiated from the AETR. The AETR — defined as the tax paid divided by the income from capital-is commonly seen in income analysis. This measures the average tax burden on income from all past investment in an average project.

$$
\text { AETR }=\frac{\text { Tax Paid }}{\text { Income }} \quad \text { METR }=\frac{\text { Rol (Before Tax })- \text { Rol (After Tax })}{\text { Rol (Before Tax })}
$$

The METR is calculated based on the economic concept that taxpayers seek to maximize profits and, as a result, invest up to the point where the marginal benefit of the incremental investment equals its marginal cost. In order to calculate the rate of return on the marginal project, all the tax provisions that impact the ROI are included. The METR is more useful than the AETR because it looks at the impact of tax on profit-maximizing business. A profit-maximizing investor would invest up to the point when the return on the marginal investment is equal to the market rate of return. As the market rate of return is known, and the impact of the tax provisions can be calculated, the rate of return on a marginal investment can be easily computed. To calculate the AETR, on the other hand, one needs to look at the effective tax rate of a "typical" project; such a project can be marginal or not, and its return can only be found through survey data.

Further, the METR is a forward-looking measure that analyzes the burden to be faced after a new investment in the business. As investment in capital is a key driver of productivity, the METR provides a useful methodology to measure this burden in its various forms. The AETR, on the other hand, includes only the impact of past investments on the tax paid at the current date, since past investments result in depreciation deductions that impact the profits and hence the current tax owed. ${ }^{22}$

But the AETR is useful because it incorporates all the taxes that a firm is liable to pay. The METR incorporates all the taxes that impact the incentive to invest in capital. But flat-fee taxes not related to firm profit, production, or capital inputs do not have any effect on the METR (see appendix 3.A). This is because flat fees do not respond in any way to the level of investment in capital and hence do not appear in any calculation of the marginal investment. As a result, the METR cannot tell us anything about the burden that flat fees impose on a business. In case the local fees cumulatively add up to a large amount, they could determine whether a project is initially profitable or not. As a result, in countries where there are a number of local taxes that together impose a big burden on business, the AETR is a useful measure and provides a more complete picture of the overall impact of the tax system on investment.

tax burdens and other regulations on business conditions. While some international comparisons are based primarily on opinions of different segments, others are based on a mixture of opinion, surveys, and other attempts to gather objective information. Important among surveys that do not rely purely on respondents' opinions are the pioneering 1999 World Bank World Business Environment Survey (WBES), covering 80 countries, ${ }^{23}$ the annual World Bank Doing Business surveys (since 2004), ${ }^{24}$ and

\footnotetext{
${ }^{22}$ The Devereux-Griffith approach allows for an AETR to be calculated on the future stream of cash flow from an investment. But assumptions have to be made on the profitability of the investment.

${ }^{23}$ See Batra, Kaufmann, and Stone (2002).

${ }^{24}$ The most recent report is available at the World Bank, Doing Business Website-http://www.doing business.org/downloads.
} 
the annual cross-country tax-competitiveness reports of the C.D. Howe Institute in Canada (since 2005). The WBES, almost a decade old, is now of less interest than the other two international surveys.

3.2.3.1 The tax-competitiveness reports of the C. D. Howe Institute. Though prepared with a Canadian audience in mind, these reports are of interest because they report the METRs for capital investments for typical multinational corporations facing an internationally benchmarked (risk-free) cost of capital. These are reported for 80 countries (in the 2007 report) using a consistent methodology. Countries covered include Organisation for Economic Co-operation and Development (OECD) economies and a selection of important developing economies such as Argentina, China, India, and South Africa.

The reported METRs measure ". . . the amount of tax paid as a percentage of the pre-tax returns on investment. This measure is based on the assumption that the amount of capital stock invested in an industry is determined by businesses maximizing their stock market values when investing in machines, structures, land, and inventory. Investment is determined at the level where the risk-adjusted rate of return on capital is at least equal to the cost of capital" (Mintz 2007).

The tax burden presented in these reports differs conceptually from those in the Doing Business indicators (described below) in that they include VAT or sales taxes in arriving at the tax burden reflected in the METR. Second, the reported METRs adjust for ROI risk by focusing on the risk-free cost of capital. But the reported measures do not seek to capture tax risks due to local tax differences. In contrast, the Doing Business indicators also seek to measure the tax-compliance costs incurred by businesses.

3.2.3.2 Doing Business indicators (DBI). Doing Business indicators (DBI) examine the business environment in 181 countries (2009), focusing on 10 crucial business concerns: starting a business, dealing with licenses, employing workers, registering property, getting credit, protecting investors, paying taxes, trading across borders, enforcing contracts, and closing a business. ${ }^{25}$ These indicators reflect both the impact of policies (including tax policy) and their administration. Like effective tax rates, the DBI are computed for a defined business case, thus permitting comparison across countries, but limiting their usefulness in evaluating the environment faced by other types of businesses. A further limitation is that there is no consideration of whether the defined business case reflects how most businesses in a particular country are structured, making the results less reflective of prevalent practices in

\footnotetext{
25 "The ease of doing business index ranks economies from 1 to 181 . The index is calculated as the ranking on the simple average of country percentile rankings on each of the 10 topics covered in Doing Business 2009. The ranking on each topic is the simple average of the percentile rankings on its component indicators." See World Bank's Doing Business 2009 report, p. 82, available at the World Bank, Doing Business Website-http://www.doingbusiness.org/downloads.
} 
countries where the size, set-up, and practices of the typical business markedly differ from the defined case. The other important advantage of the DBI is that, as with effective tax rates, they are relatively inexpensive to assemble in comparison with, say, large-scale business surveys. Further discussion of specific limitations of the tax indicators follows.

The DBI tax section includes three categories of tax indicators: ${ }^{26}$

(i) Tax payments

- Total number of taxes and contributions paid, including consumption taxes

- Method and frequency of payment

(ii) Time required to comply with three major taxes

n Collecting information to compute tax payable

- Completing tax forms, filing with proper agencies

- Arranging payment or withholding

- Preparing separate tax accounting books.

(iii) Total tax rate

- Profit or corporate income tax

- Social contributions and labor taxes paid by employer

- Any cost associated with collecting and complying with VAT and sales tax regimes, but not the taxes themselves

- Property and property-transfer taxes

- Dividend, capital gains, and financial transaction taxes

- Waste collection, vehicle, road, and other taxes.

The Doing Business methodology distinguishes between taxes borne and taxes collected by business. Taxes borne are taken to be those that directly affect the computed profit of the business and the price per unit reflected in profit computations. These taxes are included in the total tax rate indicator. It is noteworthy that certain fees are included (for example, waste collection) as are other nontax but compulsory levies, such as social security contributions. Taxes collected include, importantly, the VAT or sales taxes and withheld taxes. For taxes collected, only costs of collection and compliance are included-not the taxes themselves.

While major components of business taxation reform would affect many of the DBI positively, there are a number of considerations to keep in mind. First, it should be noted that the Doing Business "case," although intended to be a "medium" firm, is defined on the basis of international norms. Many developing countries would

${ }^{26}$ Ibid. Footnote 24. p. 78. 
actually categorize the company as large. Thus, if a new small and medium enterprise tax regime is enacted, it might not affect the DBI. ${ }^{27}$

The time required to comply with three major taxes is limited only to time taken for data collection, preparation, and filing tax returns. On the one hand, it potentially includes much, if not all, of the underlying accounting work that firms might be expected to undertake for their own benefit, apart from tax preparation. It also does not include followup, such as audits, inspections, and appeals, which can be both frequent and significant in developing and transition countries. ${ }^{28}$

Similarly, reform of the tax code to make it more transparent and accessible, while potentially significantly reducing the cost of compliance, does not get reflected in the DBI. As a result, major TA reforms-with far-reaching consequences for the investment climate-may not be fully reflected in the DBI.

\subsubsection{Cost-of-compliance and business surveys}

Broader analysis of the range of experiences with tax compliance in a particular country often requires a dedicated tax-compliance cost survey. Such surveys have become relatively common in many OECD countries, but have only recently been undertaken in developing and transition countries (including India, Malaysia, and South Africa).

Survey instruments need to be tailored to the specifics of the tax system in the country in question-with regard to both the relevant business taxes in the country and the issues of most concern to stakeholders or concerned governments.

A well-designed survey, covering a relatively large and representative sample of the business community, can provide much useful information about business compliance costs. Examples include the opportunity cost of time spent on tax obligations (such as registration, return preparation and filing, queries, objections, appeals, inspections, and audits), and variations in the size and correlates of compliance costs by type of company, location, size, and type of activity.

Such surveys can greatly help focus reform programs by identifying where compliance burdens are most onerous-for example, which taxes, tax law provisions, and procedures impose the greatest burden on business. They can also be used for monitoring and evaluation purposes_of any reform initiative that seeks to lower business compliance costs.

\footnotetext{
${ }^{27}$ The specified company in the DBPT case study has a start-up capital of 102 GNI per capita and turnover of 1,050 GNI per capita, and employs 60 people. For more details see Doing Business website: http://www.doingbusiness.org/downloads.

${ }^{28}$ The DBI attempts to limit the time taken to only the extra time taken specifically for tax accounting. But this may not always be easy to do, particularly for small businesses, which often claim that they maintain accounts solely because of tax-compliance requirements.
} 
Depending on the purpose, the survey sample may be small or large. In either case, it should, as far as possible, be structured as a representative or scientific stratified sample of the relevant business community. Relevant strata (for example, size, legal form, type of activity, geographic location) should be dependent on the focus of the survey. ${ }^{29}$ For large businesses, only information that is quantified as money in business accounts will be relatively reliable. For any other compliance costs (director's time spent complying, illegal payments, and so on), information generated may be based on educated guesswork. For small and informal firms that may not maintain accurate and complete accounts, responses can be best thought of as perceptions of tax-compliance costs.

Additional difficulties in measuring compliance costs exist for business activities with joint outputs. Apportioning of such costs, which cannot be directly related to particular activities, is problematic in all situations. The key area where such joint cost problems exist is in the apportionment of accounting and recordkeeping costs between commercial and tax accounting. While professional accountants are usually clear about the distinction, small business owners-especially in developing and transition countries-often claim that they only maintain accounts because of tax obligations. Whether or not this is an exaggeration, it is likely to influence the time estimates reported by small business for tax preparation. ${ }^{30}$ Other areas include apportionment of capital costs (such as for computer hardware) and time spent by senior management. Also, where costs or benefits occur at different points in time, estimates of cash-flow benefits or costs will be sensitive to the opportunity cost of funds assumed, as well as to assumptions made about the timing of cash accruals and disbursements.

To the extent that businesses outsource their tax accounting and related work to tax professionals, information from businesses themselves may need to be supplemented by information from surveys of professional tax practitioners. ${ }^{31}$ Even if the detailed tax work is outsourced, direct surveys of business taxpayers (perhaps less frequent) will still prove useful, if for no other reason than to find out what activities are outsourced and why.

Surveys of business taxpayers may be able to provide information on how they perceive a number of important tax environment parameters, including:

\footnotetext{
${ }^{29}$ Survey responses are likely to have a margin of error, especially in developing countries.

${ }^{30}$ As discussed, the DBI of time taken includes the time for underlying accounting calculations and does not distinguish them from tax accounting time.

${ }^{31}$ This is especially true in countries where tax laws require business accounts to be certified by professional auditors.
} 
- Which taxes were paid

- How much time/money was spent on tax preparation:

- By type of tax (for example, CIT, VAT, payroll taxes)

- By tax procedure (for example, claiming a particular deduction, obtaining exempt certification)

- By activity (for example, registration, filing, inspections, audits, and queries)

- How long tax assessments take and how many years of returns filed had yet to be finally assessed

- How often they are due for VAT or income tax refunds and how long refund processing takes (or if they receive refunds at all)

- The frequency and duration of tax inspections of different types

- The incidence of penalties and the transparency of penalty proceedings

- Frequency, duration, cost, and experience with appeals and other dispute and grievance procedures

- Special problems faced by tax withholders

- Experience with tax raids and investigations, if any

- The fairness, competence, and helpfulness of tax authorities

- Tax evasion

- Harassment and extortion by tax authorities

- Frequency and complexity of legislative changes in the tax rules

- Experience with training provided by authorities when new forms or rules are enacted

- If tax authority's enforcement policies are consistent across regional offices

- The merits of compliance versus noncompliance.

From these and other parameters, surveys can document the average cost and time-as well as the distribution of the parameter being studied-across taxpayer categories. Costs and durations are often skewed; the bulk of respondents face low costs or time, while a few face extremely long durations and high costs.

Given stakeholder concerns, surveys can either be narrowly targeted to specific groups or focus on specific tax provisions or have a broader focus, looking at most types of business taxpayers and a full slate of compliance activities.

For narrow surveys, especially if they are planned to be conducted frequently, standard methods can be devised. For example, in the United Kingdom, HM Revenue 
and Treasury has, since 2005, conducted regular Compliance Cost Assessments (CCAs) and Compliance Cost Reviews. The reasoning is presented as follows:

In line with Government commitments to reduce the compliance burden on businesses, HM Revenue and Customs (HMRC) publish impact assessments which consider the likely change in compliance costs whenever a policy is introduced or changed. HMRC carries out Compliance Cost Reviews (CCRs) of these impact assessments after the relevant measures have been implemented to confirm whether the original assessment was accurate and reasonable. (HM Revenue and Customs 2007)

As the paragraph suggests, these CCAs are focused on specific tax law or procedural changes and are carried out using small samples of taxpayers or tax professionals. The CCA methodology is partly standardized via a checklist developed for HMRC project teams (who, incidentally, are independent of normal HMRC officials). ${ }^{32}$

Another method of analyzing compliance costs is time and motion studies, such as the standard cost model (SCM) pioneered in the Netherlands and now used in several western European countries. ${ }^{33}$ These are carried out by experts, through intensive interviews with a "typical" firm for which each procedure is analyzed. The advantage of the SCM is that the expert can usually draw out more considered and, one hopes, more accurate information about the time required to complete certain procedures. This may be a cost-effective approach to monitoring and evaluation in countries where officials are well trained and interpretations of tax regulations are reasonably consistent. ${ }^{34}$ But the SCM method may be less suitable for most developing and transition countries, where practice can deviate sharply from theory, especially if there is a significant problem of inconsistent treatment across firms-and where businesses may face problems with bureaucratic harassment, delays, and demands for bribes.

In constructing a sample for a business survey, a number of issues need to be dealt with. The sample should ideally be a representative or stratified random sample of the relevant business community, including separate samples of businesses and tax professionals. Appropriate strata will depend on the purpose of the survey or assessment but could distinguish such things as size, legal form, type of activity, and geographic location.

While the ideal population database to draw the business sample from is the master file of the revenue authorities (or the taxpayer number database), this may not always be feasible. This or other population sources will often impose restrictions on

\footnotetext{
32 See HM Revenue and Customs (2007a).

33 See SCM Network.

${ }^{34}$ For a recent example that provides a good idea of both the strengths and weaknesses of the SCM approach, see Ministry of Finance (MoF), the Netherlands (2005).
} 
the stratification possible and also possibly introduce some bias in the sample (to the extent that some types of businesses are left out of the database).

In choosing the type of survey, different methods are found to have different strengths and weaknesses, as table 3.1 illustrates.

The availability of the Internet has made online surveys feasible. This was the method adopted by the FIAS (2007) in its survey of tax practitioners in South Africa. In terms of the parameters in table 3.1, online surveys can be rated as low, medium (around 15 percent), medium to high, and medium and low.

Response rates to compliance-cost surveys are sensitive to whether questions relating to illegal activity are asked or not, even if surveys are anonymous (mailed or via the Internet). This can be true even if questions are asked obliquely. For example, "What proportion of turnover do firms like yours typically report to the tax authorities?" or "Do firms similar to yours make any unofficial payments?" Table 3.2 is revealing.

TABLE 3.1 Survey types

\begin{tabular}{|l|c|c|c|}
\hline Survey characteristics & Face-to-face & Telephone & Mail \\
\hline Costs & High & Medium & Low \\
\hline Response rate & High & High & Low \\
\hline Feasible questionnaire length & High & Medium & Low \\
\hline Data quality & High & Medium & Low \\
\hline Bias in respondents & Low & Medium & High \\
\hline
\end{tabular}

Source: Vaillaincourt 1987.

TABLE 3.2 Response to questions on bribe payment pretests (canvassed) versus final (mailed) sample

\begin{tabular}{|l|c|c|c|c|}
\hline & \multicolumn{2}{|c|}{ Pretests } & \multicolumn{2}{c|}{ Final sample } \\
\cline { 2 - 5 } & $\begin{array}{c}\text { Salaried } \\
\text { taxpayers }\end{array}$ & Others & $\begin{array}{c}\text { Salaried } \\
\text { taxpayers }\end{array}$ & Others \\
\hline Percentage admitting to bribing & 4.8 & 7.7 & 22.7 & 42.4 \\
\hline Percentage denying bribing & 81.0 & 69.2 & 41.2 & 21.2 \\
\hline Percentage not commenting & 14.3 & 23.1 & 36.1 & 36.4 \\
\hline Response rate (\%) & 100.0 & 100.0 & 96.0 & 46.5 \\
\hline Potential maximum bribe payers (\%) & 19.0 & 30.8 & 58.8 & 78.8 \\
\hline
\end{tabular}

Source: Chattopadhyay and Das-Gupta 2002a. 
While items included in the survey instrument or questionnaire will depend on the focus of the survey, pretesting-particularly via focus group meetings with tax professionals-is always a good idea.

It should be noted, in closing, that impact analysis may have to be undertaken primarily on the basis of "expert judgment" for relatively small reform projects that may not have sufficient funds for full-scale monitoring and evaluation. If so, the "expert" should be independent of the project, but knowledgeable about both the subject and the country.

\subsubsection{Including taxpayer perception in surveys}

Tax surveys that include the aspect of taxpayer perception provide valuable inputs in the design of a tax simplification intervention and could be used to benchmark its progress on issues of political economy. While the survey questions on time and cost of paying taxes are useful, how the taxpayer perceives the tax system helps policy makers in the design of the intervention and its likelihood of support from business and tax authorities. Important aspects of the survey are to assess the level of trust taxpayers have in the tax offices and the image and credibility of the institutions, and to assess the level(s) of public understanding of the working environment of the institution. In the case of Sierra Leone, for example, it was found that the low level of trust of taxpayers in the government drives the low level of compliance. Hence, any tax simplification program in Sierra Leone has to address the supply-side issues and emphasize taxpayer education and improving taxpayer morale.

\subsection{A Framework for Designing, Monitoring, and Evaluating Projects}

Many potentially useful indicators for business tax reform are available. Reform project teams working with government clients should first establish project objectives, then determine what indicators are relevant and feasible for the project. A logical framework for the monitoring and evaluation of a business tax reform project should include:

- A narrative description of the objectives envisioned for the project, project outputs, activities needed to achieve these objectives, and inputs (such as budget and human resources) needed

- A list of objectively verifiable indicators of outputs associated with particular outcomes, together with descriptions of their means of verification

- An assessment of relevant risks and assumptions that may affect the progress of the project. 
Examples of monitoring indicators for both tax policy and TA are given in tables 3.3 and 3.4, respectively. Other areas of TA, not included in table 3.4, but which can be monitored, are listed in chapter 5 .

TABLE 3.3 A summary of measures for monitoring and evaluating tax policy

\begin{tabular}{|c|c|c|c|}
\hline Parameter & Description & $\begin{array}{l}\text { Outcome indicator } \\
\text { and measurement }\end{array}$ & Expected impact \\
\hline $\begin{array}{l}\text { Broadening the tax } \\
\text { base }\end{array}$ & $\begin{array}{l}\text { Fewer special tax } \\
\text { exemptions and } \\
\text { deductions }\end{array}$ & $\begin{array}{l}\text { Number of special } \\
\text { tax exemptions and } \\
\text { deductions }\end{array}$ & $\begin{array}{l}\text { Increased numbers of } \\
\text { taxpayers }\end{array}$ \\
\hline $\begin{array}{l}\text { Effectiveness of } \\
\text { tax incentives }\end{array}$ & $\begin{array}{l}\text { Tax holidays versus } \\
\text { investment-linked } \\
\text { incentives }\end{array}$ & $\begin{array}{l}\text { Replacement of } \\
\text { tax holidays with } \\
\text { investment incentives }\end{array}$ & $\begin{array}{l}\text { Increased investment } \\
\text { in fixed capital over the } \\
\text { medium term }\end{array}$ \\
\hline $\begin{array}{l}\text { Improved } \\
\text { administration of } \\
\text { tax incentives }\end{array}$ & $\begin{array}{l}\text { Who hands out } \\
\text { special tax regimes }\end{array}$ & $\begin{array}{l}\text { Tax incentives } \\
\text { provided only through } \\
\text { finance ministry }\end{array}$ & $\begin{array}{l}\text { Less revenue leakage, } \\
\text { less corruption }\end{array}$ \\
\hline $\begin{array}{l}\text { Streamlined } \\
\text { business taxes } \\
\text { and (quasi-fiscal) } \\
\text { licenses }\end{array}$ & $\begin{array}{l}\text { Licenses, fees, and } \\
\text { user charges by } \\
\text { various ministries } \\
\text { and state and local } \\
\text { governments }\end{array}$ & $\begin{array}{l}\text { Reduced number } \\
\text { of different taxes, } \\
\text { licenses, and fees } \\
\text { levied by various levels } \\
\text { of government }\end{array}$ & $\begin{array}{l}\text { New business } \\
\text { formation, formalization } \\
\text { and investment }\end{array}$ \\
\hline $\begin{array}{l}\text { Reduced tax } \\
\text { burden on } \\
\text { businesses }\end{array}$ & $\begin{array}{l}\text { Overall burden } \\
\text { imposed by the tax } \\
\text { system on investment }\end{array}$ & $\begin{array}{l}\text { Marginal effective tax } \\
\text { rate (METR), average } \\
\text { effective tax (AETR) }\end{array}$ & $\begin{array}{l}\text { New business } \\
\text { formation, formalization, } \\
\text { and investment }\end{array}$ \\
\hline $\begin{array}{l}\text { Increased fairness } \\
\text { of the tax system }\end{array}$ & $\begin{array}{l}\text { Perception of how fair } \\
\text { the tax system is }\end{array}$ & $\begin{array}{l}\text { Measurement through } \\
\text { surveys of taxpayers }\end{array}$ & $\begin{array}{l}\text { Increased formalization } \\
\text { and compliance }\end{array}$ \\
\hline
\end{tabular}

Source: Authors 


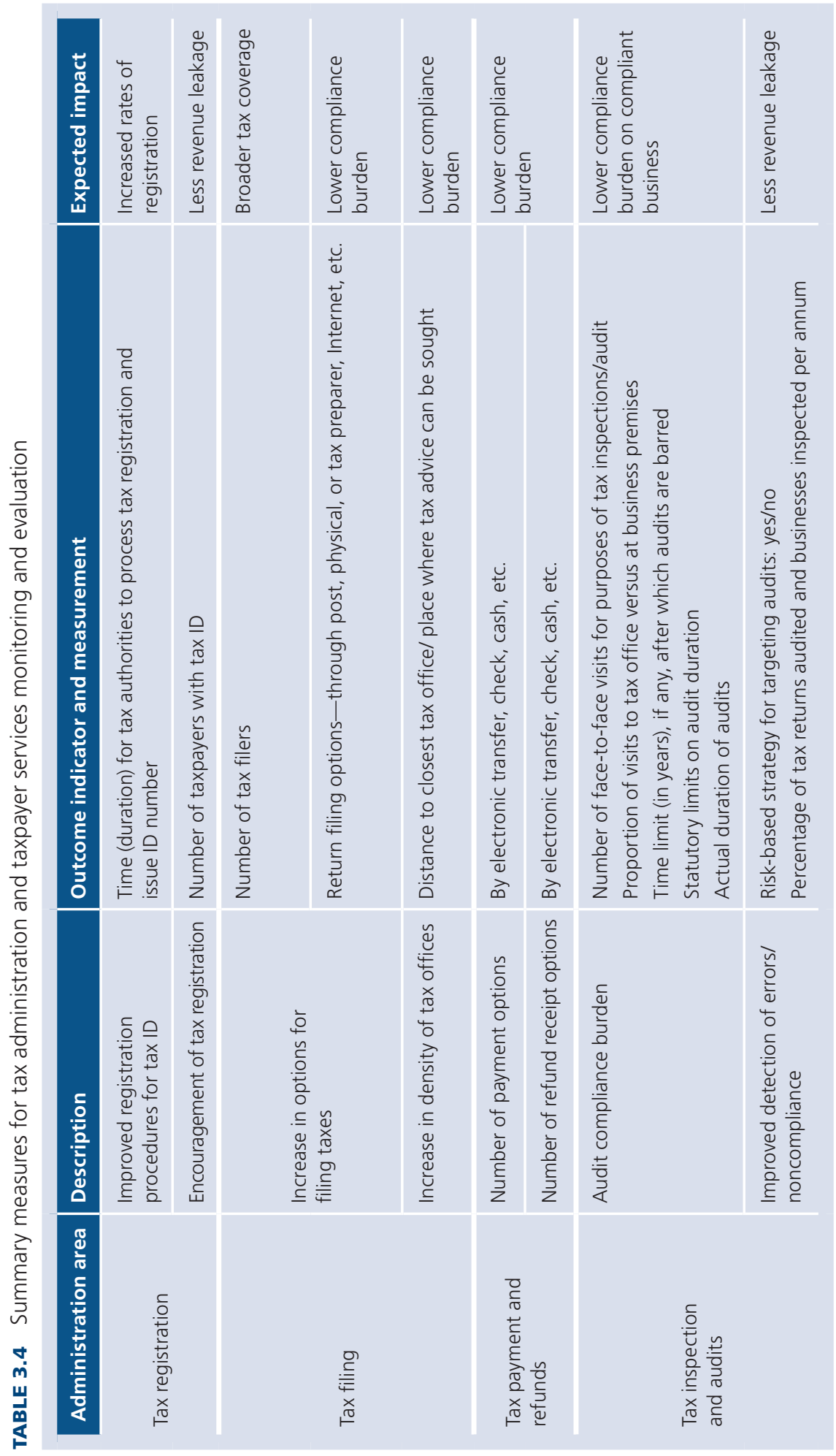




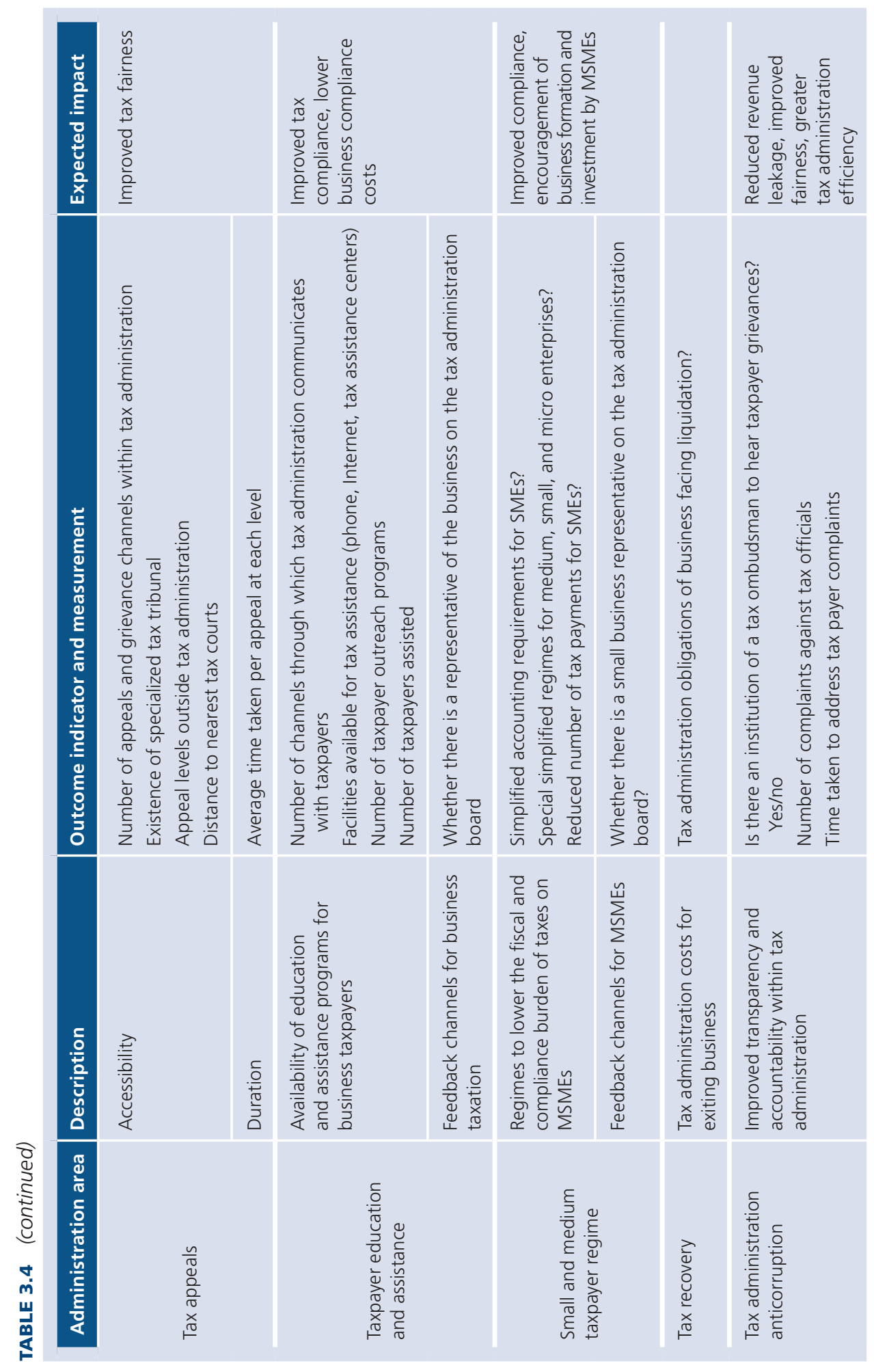




\section{APPENDIX 3A}

\section{Methodology for Estimating the Marginal Effective Tax Rates (METRs)}

(Mintz and Chen 2008)

The standard method used to estimate marginal effective tax rates (METRs) is extensively documented (see, for example, Boadway, Bruce, and Mintz 1984; King and Fullerton 1984). Chen and Mintz (1993) modified this method by incorporating some miscellaneous taxes such as capital- or asset-based taxes and property-related taxes. Following are the general formulas used in their study. Note that these formulas are for profitable, and hence tax-paying, firms only. For a tax-loss case, the formulas would be much more complicated and are not discussed here.

\section{A.1 Marginal Effective Tax Rate $(t)$}

The METR on a given type of capital is defined as the proportional difference between the gross-of-tax rate of return $\left(r^{G}\right)$ required by a firm and the net-of-tax rate of return $\left(r^{N}\right)$ required by an investor; $r^{G}$ is the marginal revenue product (or user cost of capital, in equilibrium) net of economic depreciation. The after-tax rate of return is the weighted average of the return to debt and equity securities held by the financial investor. Thus, the effective tax rate $(t)$ is defined as

$$
t=\left(r^{G}-r^{N}\right) / r^{G}
$$

\section{A.2 The Net-of-Tax Rate of Return on Capital $\left(r^{N}\right)$}

The net-of-tax rate of return on capital is defined by the formula

$$
r^{N}=\beta i+(1-\beta) \rho-\pi
$$

This is the rate of return on capital required by financial investors or suppliers of investment funds to firms. Note that financial investors often include firms themselves when there is equity generated internally. 


\section{A.3 The Real Cost of Financing $\left(r^{f}\right)$}

The real cost of financing $\left(r^{f}\right)$ is one of the main components of the cost of capital or gross-of-tax rate of return $\left(r^{G}\right)$ on capital. The real cost of financing $\left(r^{f}\right)$ is defined by

$$
r^{f}=\beta i(1-U)+(1-\beta) \rho-\pi
$$

with $\beta=$ the debt-to-assets ratio, $i=$ cost of debt, $U=$ the statutory corporate income tax rate, $\rho=$ cost of equity, and $\pi=$ inflation rate. That is, the cost of financing for the firm is the weighted-average cost of financing net of the inflation rate.

\section{A.4 The Gross-of-Tax Rate of Return $\left(r^{G}\right)$ on Capital ${ }^{35}$}

\section{(a) Depreciable assets (buildings and machinery and equipment)}

$$
r^{G}=(1+t m)\left(r^{f}+\delta\right)(1-k)\left[1-A+\tau(1-U) /\left(\alpha+r^{f}+\pi\right)\right] /[(1-U)(1-t p-t g)]-\delta
$$

Where $t m=$ tax on transfer of property or a transaction tax (for example, import duty and sales tax) on capital goods wherever this is applicable; $r^{f}=$ real cost of financing (as defined in section 3A.3); $\delta=$ economic depreciation rate; $k=$ investment tax credit rate; $A=$ the present value of tax benefit from the investment allowance and depreciation allowance; $\tau=$ capital tax rate; $\alpha=$ tax depreciation rate; $t p=$ property tax rate based on the rental value; and $t g=$ gross receipts tax rate or presumptive tax that is based on the gross revenue.

\section{(b) Inventory}

$$
r^{G}=(1+t m)\left(r^{f}+U \pi \zeta\right) /[(1-U)(1-t g)]+\tau
$$

Where $t m=$ sales tax on raw materials where it is applicable, and $\zeta=1$ for the FIFO (First In First Out) accounting method, 0 for LIFO (Last In First Out), and 0.5 for the average cost method.

\section{(c) Land}

$$
r^{G}=r^{f}(1+t m)\left[1+\tau(1-U) /\left(r^{f}+\pi\right)\right] /[(1-U)(1-t p-\operatorname{tg})]
$$

Where $t m=$ property transfer tax.

\footnotetext{
35 Formulas provided here are only for the regular case where companies are profitable and pay taxes. For the tax-holiday case or the case of tax reduction for a limited period, the formulas for depreciable assets are more complicated in that the present value of tax allowances needs to be adjusted to reflect the true impact of the tax holiday or tax reduction on the METR. For nondepreciable assets, such as inventory and land, the formula for the tax-holiday case is the same as that for the tax-paying case except that the statutory tax rate(s) may differ due to the lower or zero rate arising from tax incentives.
} 


\section{(d) Aggregation}

The METR for a given industry is the proportional difference between the weighted average of the before-tax rate of return by asset type and the after-tax rate of return; the latter is the same across asset types within a given sector. ${ }^{36}$ That is, the METR for industry $i\left(t_{i}\right)$, is calculated as following:

$$
t_{i}=\left(\Sigma_{j} r_{i j}^{G} w_{i j}-r^{N}{ }_{i}\right) / \Sigma_{j} r^{G}{ }_{i j} w_{i j}
$$

where $j$ denotes asset type (that is, investments in buildings, machinery, inventories, and land) and $w_{i j}$ denotes the weight of $j$ in industry $i$.

\section{A.5 Calculating the METRs: The Example of Mauritania}

The METR $(t)$ is defined as

$$
t=\left(r^{G}-r^{N}\right) / r^{G}
$$

where the gross-of-tax rate of return is $r^{G}$ and the net-of-tax rate of return is $r^{N}$.

The net-of-tax rate of return on capital $\left(r^{N}\right)$ is defined by the formula

$$
r^{N}=\beta i+(1-\beta) \rho-\pi
$$

In the case of Mauritania,

$$
i=12.56 \%,{ }^{37} \beta=0.4, \rho=12.56 \%, \pi=7.3 \%
$$

Therefore, $r^{N}=4 \%$.

The real cost of financing $\left(r^{f}\right)$ is defined by

$$
r^{f}=\beta i(1-U)+(1-\beta) \rho-\pi
$$

where the parameters are as above and $U$ is the corporate income tax rate.

In the case of Mauritania,

$i, \beta, \rho, \pi$ are as above and $U=0 \%$ the corporate income tax rate in the case of a small business, as they are assessed via the turnover tax.

Therefore, $r^{f}=12.56 \%$.

\footnotetext{
${ }^{36}$ The net-of-tax rate of return can be the same across all the sectors when there is no sectoral differentiation in the statutory income tax rate.

${ }^{37}$ The variable $i$ is derived from the international interest rate using the arbitrage assumption that the local interest rate-after deducting taxes on interest income and after inflation-should equal the international interest rate. As the international real interest rate is known $\left(r^{*}=4 \%\right)$, as well as the personal income tax on interest income $\left(T_{i}=10 \%\right)$, the nominal interest can then be derived as $\left(r^{*}+\pi\right) /\left(1-T_{i}\right)$.
} 


\section{A.6 The Gross-of-Tax Rate of Return $\left(r^{G}\right)$ on Capital}

\section{(a) Depreciable assets (buildings and equipment)}

$$
r^{G}=(1+t m)\left(r^{f}+\delta\right)[1-A] /[(1-U)(1-t p-t g)]-\delta
$$

In the case of the manufacturing sector, apart from the parameters used above, $t m=14 \%, \delta=20.5 \%$ (equipment) and 9\% (buildings), and $\operatorname{tg}=8$ percent. (This is a shortened version of the formula in the appendix 3A with no investment allowance and capital taxes.)

Therefore, $r^{G}=11.41 \%$ (for equipment) and $r^{G}=6.50 \%$ (for buildings).

\section{(b) Inventory}

$$
r^{G}=(1+t m)\left(r^{f}+U \pi \zeta\right) /[(1-U)(1-t g)]+\tau
$$

In the case of inventory, the average cost method is used, where $\zeta=0.5$. Therefore, $r^{G}=5.71 \%$.

\section{(c) Land}

$$
r^{G}=r^{f}(1+t m)\left[1+\tau(1-U) /\left(r^{f}+\pi\right)\right] /[(1-U)(1-t p-t g)]
$$

In the case of land, $t p=8 \%$ (tax on immoveable property).

Therefore, $r^{G}=13.94 \%$.

\section{A.7 Aggregation}

The METR for industry $i\left(t_{i}\right)$ is calculated as follows:

$$
t_{i}=\left(\Sigma_{j} r^{G}{ }_{i j} w_{i j}-r^{N}{ }_{i j}\right) / \Sigma_{j} r^{G}{ }_{i j} w_{i j}
$$

In the case of manufacturing, the following parameters are used for $w_{i j}$, the asset weights. Equipment $=52.4 \%$, building $=28.5 \%$, land $=0.9 \%$, inventory $=18.1 \%$. These ratios vary by sector. The variable $r^{G}$ for each asset class is given as above and so is $r^{N}$.

Therefore METR $=55.57 \%$. 


\section{APPENDIX 3B}

\section{Tax Survey Sampling}

It is extremely critical for business surveys to define their sample frame. ${ }^{38}$ Figure 3B.1 indicates that this is a complex process, as a large portion of businesses are outside the formal system. A combination of survey approaches is needed, depending on the availability of clean data and the sample frame. In the case of informal businesses, even the sample frame might be extremely difficult to obtain and a spatial approach might have to be used.

\section{B.1 Surveying Formal ${ }^{39}$ Businesses}

A sample of formal businesses could be drawn from a list of all registered businesses; these could be approached directly, using the contact information listed in the registry

FIGURE 3B.1 A sample frame for business surveys: a tax perspective

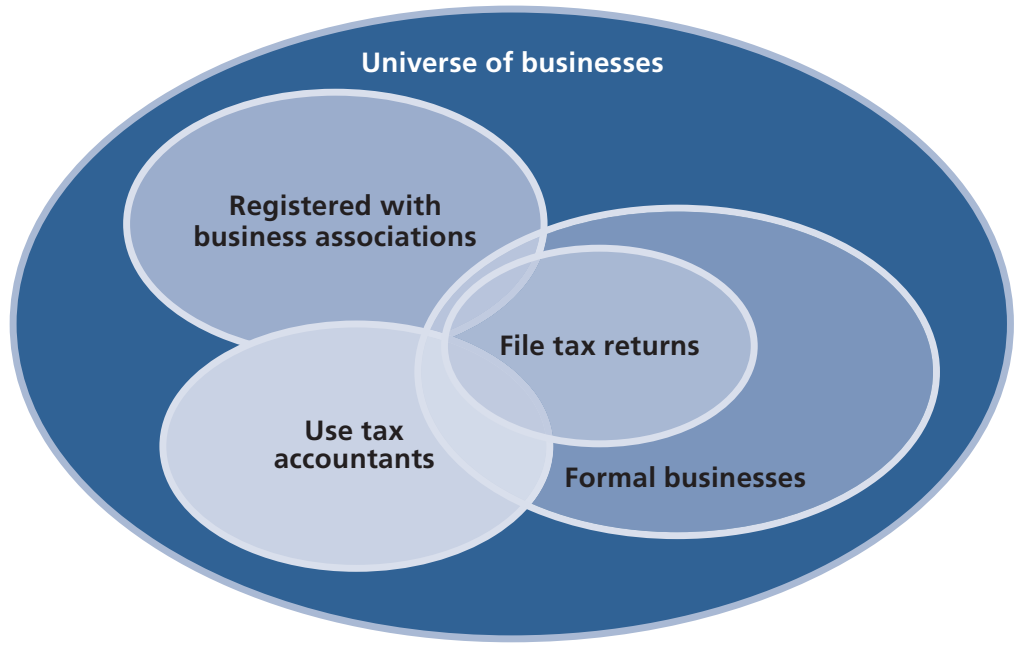

\footnotetext{
${ }^{38}$ A list that includes every member of the population from which the sample is taken.

${ }^{39}$ Formal businesses are defined here as those that are registered either with the registrar of business (or equivalent authority), the tax authority, or both.
} 
database. A separate category could consist of businesses that file regular tax returns. For this group, the data could be obtained directly from the tax returns. But deciding the sample frame for either category could be difficult in the absence of a central database of registered firms or tax filers. In the latter case, the accounts might either not be filed or the required of information might not be available, necessitating direct visits to the taxpayer. The advantage of using a business registry is that it captures some businesses that fail to file required tax returns.

Issues to be tackled when surveying formal businesses include the following.

- Business registries might not be well maintained, making it difficult to decide a sample frame due to:

- Closed businesses still listed

- Incorrect or outdated contact information

- Missing records.

- Business and tax registries could be disjointed, necessitating consolidation of separate registries from different jurisdictions or tax offices.

- The survey would need to correct any bias that these issues might bring about (especially in the second and third categories above). This could be done by directly contacting businesses in these categories and balancing the sample accordingly.

- Such a sample necessitates a labor-intensive process since surveyors must conduct surveys on site.

In some countries, businesses file annual returns with the registrar of business, in which case some basic tax data can be obtained from the registrar itself.

\section{B.2 Surveying Informal Businesses}

The difficulty in surveying informal businesses is the lack of a clear sample frame. But there are several options for developing such a frame, including the use of business associations and tax accountants. ${ }^{40}$ The advantage of using tax accountants-for the limited number of informal businesses who use them-is that collecting client data from a random sample of tax accountants (after maintaining due confidentiality) serves as a good random sample for that entire category of taxpayers.

\footnotetext{
${ }^{40}$ In some countries, it is compulsory for certain categories of business (for example, corporations) to get their accounts audited by a registered chartered accountant. In this case, chartered accountants could then be used to develop sample frames for such businesses.
} 


\section{B.2.1 Survey methods for informal businesses using geographically defined clusters}

This method involves creating a sample of businesses by randomly selecting from a list of population centers, then further selecting streets and rows, then surveying all the businesses from the sampled group. This approach is similar to the multistage sampling design used for household surveys. The advantage of this method is that it covers all kinds of businesses including household businesses.

\section{Sample size for a tax survey}

The sample size $(n)$ is determined based on the number of establishments in the sample frame. A formula propounded by Cochran (1963) used to determine the sample size $(n)$ as follows:

$$
n=\frac{N}{1+N(e)^{2}}
$$

where $n$ is the sample size, $N$ is the population size (the total number of establishments in the sample frame selected), and $e$ is the level of precision (for example, a 95\% confidence level, $e=0.05$ ).

\section{Further Guidance}

FIAS METR reports on Burkina Faso, Kyrgyzstan, Lesotho, Mauritius, Mozambique, Nigeria, Sierra Leone, Tajikistan, Uzbekistan, Yemen, and Zambia. Can be accessed on the FIAS website: http:// www.fias.net/ifcext/fias.nsf/Content/Pubs_BusinessTaxation 


\section{Chapter 4: Simplifying Tax Policy}

\section{CHECKLIST OF GOOD PRACTICES}

$\checkmark$ The government maintains a current inventory of business taxes

$\checkmark$ Policy makers understand the reason for each tax levied (for example, revenue generation, regulation, promotion of equity, and so on)

$\checkmark$ Local governments do not use regulatory instruments to raise revenue

$\checkmark$ Tax policies and instructions are drafted so as to be easily understood by taxpayers

$\boldsymbol{V}$ Tax accounts are not completely divergent from book accounts and taxable profits can be easily derived from book profits

$\checkmark$ Policy makers consider current administrative limitations when setting tax policy

$\checkmark$ The government plans and implements efforts to improve tax administration (TA)

$\boldsymbol{V}$ The government maintains a stable tax policy as far as possible

$\checkmark$ Policy makers understand the political economy implications of the tax-simplification process

The goal of this chapter is to understand the various policy dimensions of tax simplification and connected issues. Tax policy provides the necessary framework for any tax-simplification agenda. This chapter addresses the issue of multiplicity of taxes, their causes and how to address the issue, the role of simple tax laws, and simple tax accounting system for business.

\subsection{Why Levy Multiple Taxes?}

Multiple taxes impose an additional burden on businesses-however, they generate additional revenue for government. One could argue that reducing the number of taxes (by merging some and eliminating others) while managing to collect the same amount of tax revenue would satisfy both businesses and the government. While this is true, it rules out the important fact that some taxes have goals beyond raising revenue. Taxes are used to regulate (for example, environmental taxes), redistribute 
(for example, progressive income tax), introduce transparency in the collection and allocation mechanism (for example, road users' taxes, social security taxes, and other earmarked taxes), emphasize the role of institutional spending (local taxes for local public goods), force savings (government-imposed compulsory payment to pension funds), and so on. Any prescription to rationalize fewer taxes would have to address these various functions.

\subsubsection{A portfolio of taxes: reducing volatility in tax collection}

One purpose of multiple taxes is to capture different tax bases with differing levels of buoyancy and, as a result, reduce uncertainty in tax collection. A small number of taxes would expose government revenue to economic downturn in a limited number of bases. In the language of finance, this would be akin to highly leveraged government revenue. In other words, depending on a small number of taxes increases the volatility of government revenue-so a government must have a "portfolio" of taxes to reduce its exposure. A tax system that is excessively dependent on income taxes or on commodities would severely strain government revenues when gross domestic product (GDP) growth slows or when commodity prices fall, respectively. The government should levy taxes that add stability to the tax system, such as property taxes and taxes on consumption, neither of which is very elastic. Any tax-simplification reform should ensure that the resulting tax system does not become highly leveraged.

\subsubsection{Political economy and multiple taxes}

Political considerations are critical to determining the number of taxes levied in any country. Such considerations include equity, visibility, and subnational fiscal problems such as corrupt local administrators.

4.1.2.1 Promoting equity. In some cases, multiple taxes are levied to improve the equity of the tax system. ${ }^{1}$ Different taxes capture revenue from different bases, which are proxies for various levels of wealth. For example, while the progressive income tax collects revenue from those with income flows, it is possible for individuals to earn little income but have wealth in the form of capital assets such as property, shares, and bonds. A wealth tax is, in this case, used to capture revenue from such persons, who might otherwise escape taxation. The same applies to taxation of certain goods more likely to be consumed by the rich. For example, a luxury tax on rooms in five-star hotels seeks to achieve this goal. While it is generally recommended to use taxes only as a revenue-collecting mechanism and leave the social goals to be tackled on the expenditure side, creating equity and forcing redistribution are among the primary functions of a tax system. On the other hand, efforts toward

\footnotetext{
1 The idea of equity in taxation is more applicable to individuals; however, governments have not hesitated to use the taxation of legal entities in order to tax the owners of the legal entities.
} 
these goals can easily result in an overly complicated, distorted system with several taxes on a large number of tax bases.

4.1.2.2 Tax visibility. Purely political considerations also help determine the use of multiple taxes. For example, less visible taxes can raise important amounts of revenue-without public backlash. In this line of reasoning:

- Less visible taxes such as indirect taxes (sales tax, customs duty) are favored over visible taxes such as direct taxes (income tax and property tax).

- Taxes paid in small increments are favored over those involving a significant payment.

- Taxes imposed on nonresidents are favored over those imposed on residents.

This has direct implications for reform because any program that makes the tax system simpler could also make it politically unpalatable. This is an important consideration in the design of any tax-simplification intervention.

4.1.2.3 Subnational fiscal problems. A major cause of the increased number of taxes in many developing countries is the proliferation of local taxes. These are growing because:

- Local governments have constitutional or legal obligations to deliver services to citizens and businesses and are therefore granted the spending power to do so. But, when faced with weak revenue bases from standard taxes (for example, property or income tax) and insufficient intergovernmental transfers, they turn to a wide range of regulatory instruments to meet revenue targets.

- In many cases, subnational governments have limited authority to raise revenues through taxes but discretionary power to establish or enforce business regulations. Their incentive structure is, therefore, biased toward using regulations instead of taxes to fill their coffers. Part of the problem also stems from a lack of knowledge, as not all governments realize that licensing is an inefficient way to generate revenue.

- At a time when many national governments are moving toward decentralization (Shah 2004; Litvack, Ahmad, and Bird 1998), there is growing pressure on subnational administrations to find sustainable sources of revenue, thus potentially aggravating the problem. The trend toward "localization" is not limited to federal systems, but concerns unitary states as well (see Ebel 2003). In the context, it is safe to expect policy makers to search for lasting solutions to this problem.

Figure 4.1 shows the taxes levied, by level of government, in four Nigerian states. The number is as high as 30 in most cases. Such multiplicity of taxes is further analyzed in chapter 8. 
FIGURE 4.1 Taxes, charges, and fees levied by different levels of government in four Nigerian states

Cross-River: Number of Taxes, Charges, and Fees by Sector

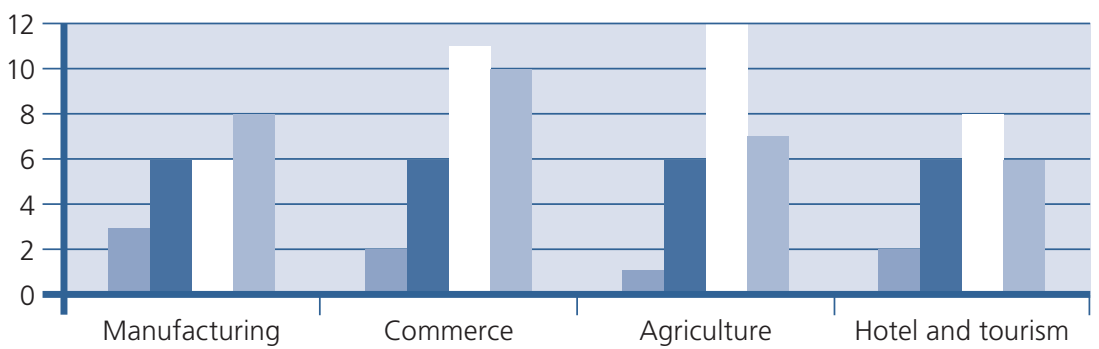

Kaduna: Number of Taxes, Charges, and Fees by Sector

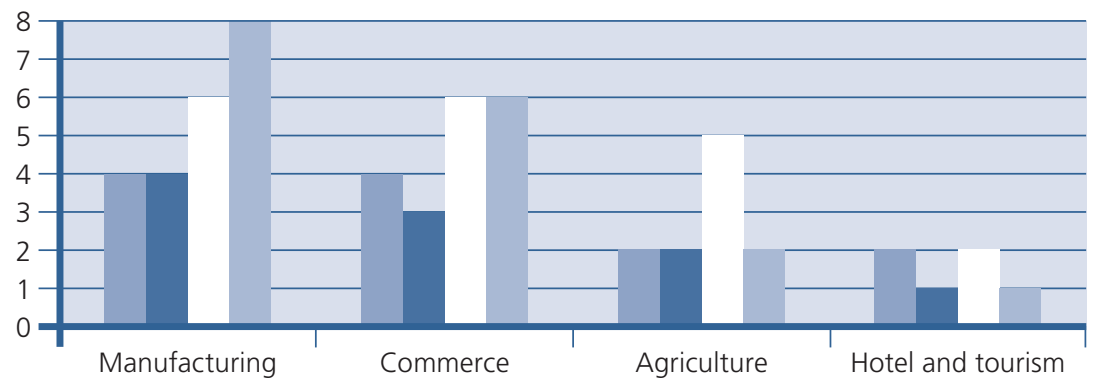

Kano: Number of Taxes, Charges, and Fees by Sector

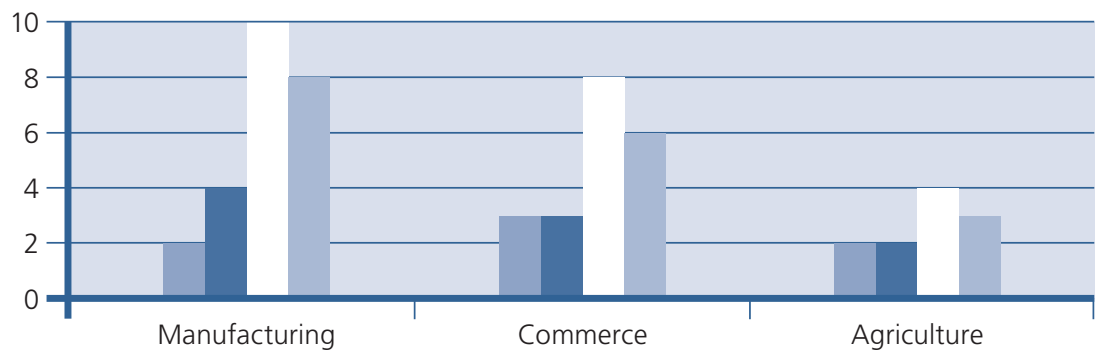

Lagos: Number of Taxes, Charges, and Fees by Sector

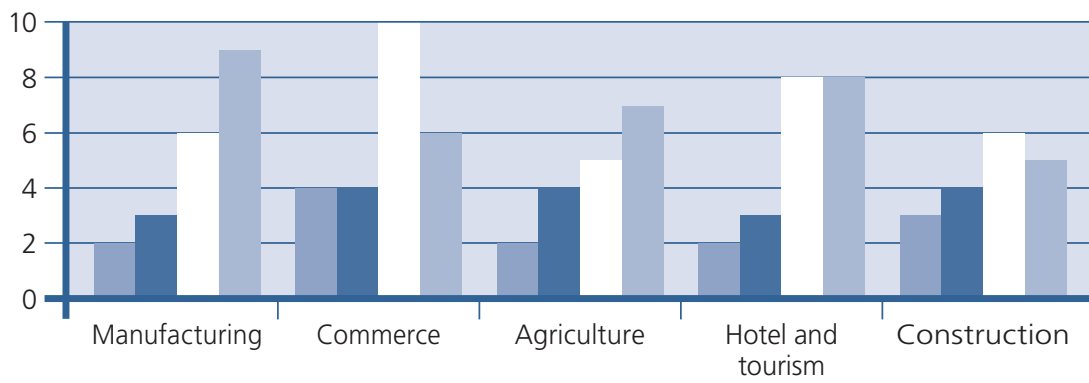




\subsubsection{Using (costly) tax policy instruments to enforce compliance}

Tax instruments at times are used to improve tax compliance. Common methods are the use of minimum taxes that are based on turnover or assets or book value of profits.

An unusual method to use tax policy to try to improve compliance is the use of taxes based on expenditure in an effort to counter the common tactic used by tax evaders of inflating expenditure to lower profit taxes. The Road Users Tax in Tajikistan and the Fringe Benefit Tax in India (repealed in June 2009) are examples of this approach. In the case of the Road Users tax, this was $2 \%$ of the total expenditure in 2008. In the case of the Fringe Benefit Tax, a fixed percentage of expenditure on items such as entertainment, and travel, was the Fringe Benefit Tax that was paid along with the Income Tax.

Minimum taxes on profit that are a percentage of gross sales are quite popular in many countries-Burkina Faso, Mali, Mauritania, and Senegal, for example.

India levies a Minimum Alternative Tax of $15 \%$ on book profits of corporations. This is for the purpose of taxing corporations that report high book profits, but plan in such a way that their taxable income is kept low.

All of these methods are tools to ensure compliance, but they impose a high tax burden on taxpayers. Imposing an expenditure tax as well as a profits tax makes them together effectively a turnover tax. The additional tax instruments also impose higher compliance costs for taxpayers. Further, these tax instruments tend to punish law-abiding taxpayers, as their use and rates are calibrated toward getting more tax out of tax evaders.

A major problem with these measures is that they tend to be extremely costly for businesses that are starting up and have negative income during the initial years. In the case of businesses that are temporarily doing badly due to market conditions, these taxes exacerbate the situation.

The solution lies in strengthening tax administration and audit capacity and using information reporting, rather than additional tax instruments, to improve compliance.

\subsection{The Purpose of Taxation: Regulation or Revenue? ${ }^{2}$}

Taxation is among the most important of all regulatory instruments. In many cases, it ends up being a revenue collection tool, with its regulatory function secondary. As mentioned above, this is routinely used as a revenue source by subnational governments. Some degree of confusion prevails among reformers, practitioners, and government

2 A detailed discussion on this topic is given in a FIAS note on subnational taxes and regulation (2008). 
agencies when it comes to defining and distinguishing regulatory and fiscal instruments. But clear definitions are needed to ensure that these instruments will be evaluated against the right set of criteria. The key distinction lies in the purpose of each instrument:

- Fees and licenses are used by governments to regulate companies and entrepreneurs. In this context, licenses are understood, in a broad sense, as "any ex ante authorizations required for any activity to commence." In principle, licenses are used by governments to regulate defined business activities in order to protect public interests such as health, safety, the environment, and social cohesion.

- Taxes refer to the diverse set of instruments by which governments levy and collect money from businesses or individuals, calculated on bases such as income, sales, production, and so on, with the overall purpose of generating revenue for the delivery of goods or services by the public sector.

- User and utility charges serve to generate revenue but, unlike taxes, are used to finance the delivery of private goods by a public entity (for example, water, sewerage, garbage collection).

Conceptually, the difference is clear. But, in practice, there is a gray area in which regulatory instruments are used mostly or exclusively to generate revenue. They are thus considered by some as taxes, while others view them as licenses, permits, or other forms of authorization. To make matters worse, there is no widely accepted terminology used consistently by policy makers-even within the same country or municipality.

\subsection{Simplifying Taxes: A Step-by-Step Approach}

Any strategy that seeks to lessen the number of taxes should take into consideration both their revenue-generating and other roles. Rozner and Gallagher (2008) define what they call the "tax guillotine" in a manner akin to the "regulatory guillotine," a tool used to reduce the number of regulatory instruments. They describe the process of simplifying taxes using the tax guillotine in three steps:

- Build a complete inventory of all taxes, fees, and compulsory contributions, both national and local.

- For each item, provide the legal basis, the policy purpose, the procedural burden for business and revenue productivity, and-last but not least-the political economy purpose.

- Use this information to combine, retain, and eliminate some of the taxes and fees. Appropriately adjust the rates of the taxes that remain to ensure that the government's revenue goals are met.

Figure 4.2 captures this strategy. 


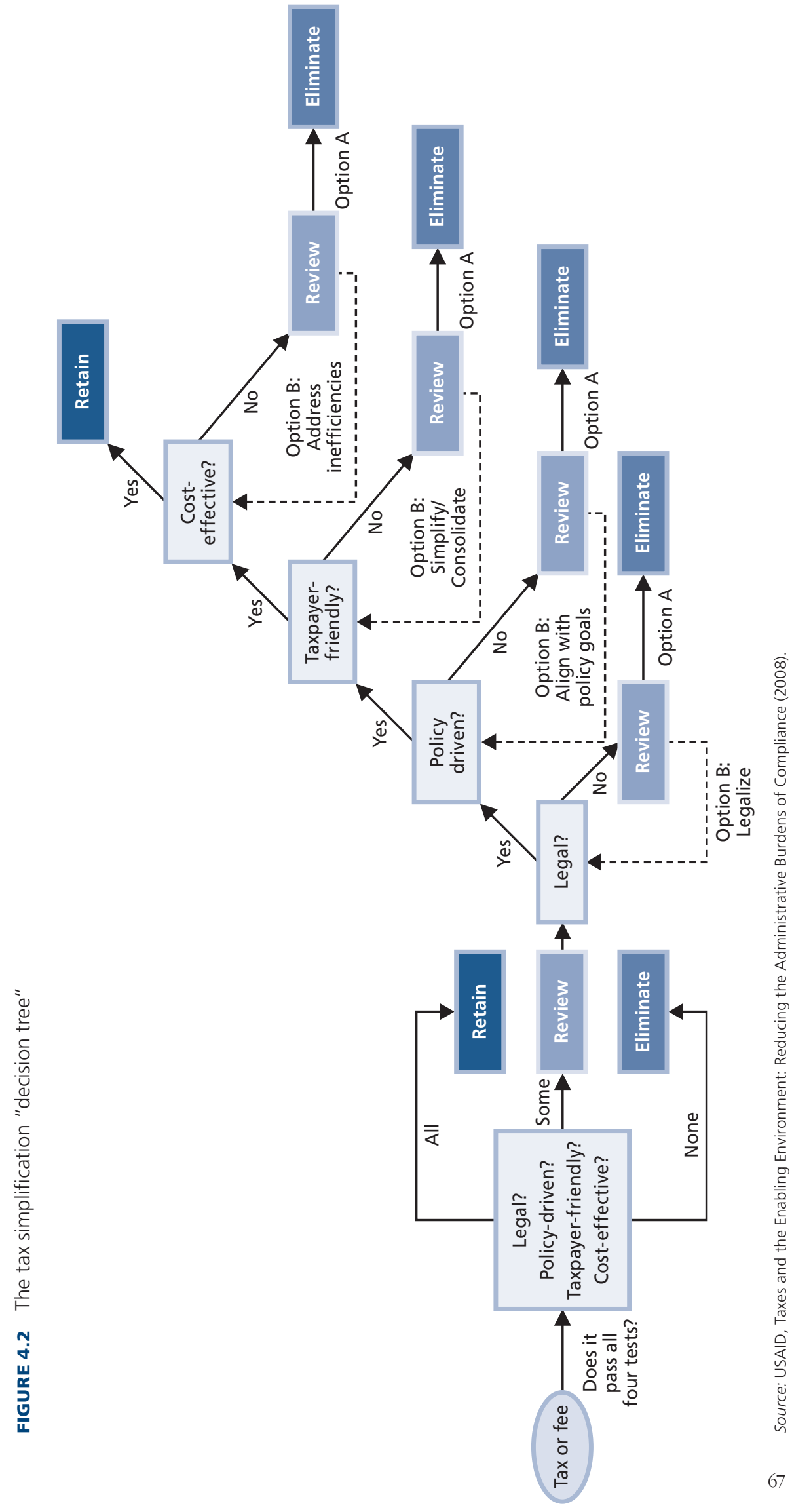


The review process is critical and should involve both stakeholders that stand to benefit and those that stand to lose. In many countries, the tax-simplification process is likely to face significant opposition from vested interests, especially those collecting taxes that might be eliminated. Strong political support of the simplification process is imperative to overcome entrenched interests (such as those of tax collectors who receive informal payments). As the private sector stands to benefit significantly from the simplification process, it should do what it can to generate such political support.

\subsection{The Importance of a Stable Tax Policy over Time}

Stable tax policy is an essential feature of a sound tax system. Frequent policy changes cost the government, which must convey these changes to the public and also oversee the tax administrators that will implement them. Frequent changes also create uncertainty for investors and may dissuade potential investors from investing and existing investors from expanding their business.

Investments made today yield returns at a future date, at which time they are usually subject to taxes. Hence, investors have to gamble on the future direction of tax rates. This results in what game theorists call the dynamic inconsistency problem. Governments may promise the same or low tax rates in the future, and investors who believe them may invest based on this promise. But there is always the risk that governments will raise tax rates anyway and extract higher revenue on investments that have already been made. Meanwhile, investors cannot reverse their investment decisions without bearing substantial costs. In light of this problem, investors might hesitate to invest unless guaranteed a high rate of return that accounts for the expected loss from a higher future tax rate. Dynamic inconsistency introduces substantial constraints on what direction an optimal tax policy may take and stresses the need for governments to avoid the reputational risks associated with employing an inconsistent policy. For example, it might be best, in some cases, for governments to stick to a promised lower tax rate in spite of its revenue implications (i) because of the risk of being characterized as untrustworthy, and (ii) because investors might factor such risks into the price of investment in that country-lowering overall investment (and revenue) in the future. Providing tax-stabilization clauses is a device that governments use to guarantee investors that the tax rates will remain unchanged during the period of their investment.

\subsection{Tax Simplification: The Role of Drafting Tax Laws ${ }^{3}$}

A simple tax code is often treated as synonymous with a simple tax system. Policy makers and businesses in both developed and developing countries frequently express

3 For a detailed study of this topic, see Thuronyi (1996). 
their frustration with what they perceive as incomprehensible tax codes. Because tax laws apply to a large number of transactions, it is imperative that their meaning is conveyed in a straightforward and simple manner, or they will result in an additional compliance burden for businesses (Thuronyi 1996).

It not necessary, however, for tax codes to be easily readable by the layperson, though this is a definite advantage. The goal of any tax code is to provide the legal basis for taxation, and it is likely that this requires the use of precise legal terms (for example, an exemption versus a deduction, tax-inclusive price versus tax-exclusive price) that might not be easily understood by the layperson. There is a move toward writing "plain language" tax codes, but this should not be at the expense of defining the intent of the law in precise terms.

\subsubsection{Explaining the intent of law to a layperson}

It is helpful to taxpayers when tax laws are accompanied by detailed explanations. Regulations, instructions, circulars, and rulings all provide greater information on the intent of the law to both taxpayers and tax administrators. For taxpayers, probably the most useful are pamphlets on their rights and responsibilities, including relevant dates for filing returns. Step-by-step instructions on how to file tax returns are also very helpful to taxpayers, though it is not uncommon for them to rely on costly tax accountants to file returns even in the simplest of cases. Some tax laws provide examples either in the main text or in the regulations. These examples explain the operation of the laws and are extremely useful in making them more understandable. But providing such examples is not common practice. It is ironic that developed countries with well-educated taxpayers provide the most comprehensive support material to help taxpayers file their tax returns, while such support is almost absent in developing countries with lower literacy rates. The impression that making the laws easy to understand does not necessarily result in additional tax revenue means that it tends to be neglected in many developing countries.

\subsubsection{Consolidating tax laws with their amendments}

Tax laws are some of the most dynamic laws, subject to change from year to year. In many countries, however, subsequent amendments are not incorporated into the primary law. Taxpayers, tax practitioners, and tax administrators have to rely on several sets of documents to inform them of the tax law at a particular point in time. It is imperative that amendments to tax laws be incorporated into the original text, along with adequate footnotes that explain the history of particular provisions. Providing a historical account of the tax law is very helpful, especially since tax laws are frequently amended. One of the implications of this is that as tax cases typically take a long time to find their way through the judicial system, it is useful to see how the law stood when the case first went to court. 


\section{BOX 4.1 Tax Code Simplification in Yemen}

The Investment Climate Advisory provided assistance to the Yemen Tax Authority to simplify the tax code. The process of simplification included making the language clear and less arbitrary, rearranging the procedural provisions by gathering the various issues together (e.g. registration and information, declaration and assessment, appeal procedures, violations and penalties, and collection and enforcement), introducing a separate section on mining activities, a separate section on small taxpayers, and anti-avoidance provisions. The process of tax code simplification goes beyond just drafting changes to provide an opportunity to correct and introduce important changes to tax policy and tax administration.

\section{Specific Provisions Included}

- Definition of permanent establishment follows international practice; wording of provision follows both UN and OECD model conventions.

- Resident individuals are taxed only on Yemeni income; businesses are taxed on worldwide income principle (according to most other countries) and granted credit against Yemeni tax for taxes paid abroad

- Determination of taxable profit brought more in line with international practice; starting point is reference to (commercial) financial accounts, unless tax laws provide for a different treatment

- Clear realization rules introduced regarding long-term contracts

- Limitation of interest deduction by rate and by debt-equity ratio introduced to protect tax base

- Depreciation schedules simplified by reducing the number of depreciation rates

- Financial leases accommodated by allowing (under strict requirements) lessee to depreciate leased assets

\subsubsection{The use of a single tax code increases transparency}

In the interest of transparency, it is a good practice to consolidate all laws with tax implications into one code (or as few as possible). Another advantage of a single tax code is that its accompanying administrative provisions span all tax laws, avoiding duplication. Large taxpayer units (LTUs) that administer most or all of the taxes for large businesses under one roof have been introduced in many countries. The use of a single administrative law is especially helpful in the case of administering taxpayers in LTUs.

In many developing countries, it is common for investment laws to include tax implications outside the tax code. This may confuse businesses, especially when different laws with tax implications are not consistent with each other. The situation is made even more complex by the use of individual agreements-with tax implicationsbetween the government and individual investors.

It is essential that all laws with tax implications be reflected in the relevant tax laws, even if these are duplicated. An interesting legal construct was established in India in 2005 with the introduction of a new law governing special economic zones (SEZs). 


\section{Box 4.1 (continued)}

- Loss carry-forward introduced for a period of 5 years on LIFO basis

- Facility introduced to allow certain business reorganizations without being taxed immediately

- Current tax exemptions maintained (e.g., NGOs; agriculture, and so on; profit distributions; interest on treasury bonds, private deposits, and so on)

\section{Procedural Provisions Simplification Included}

- Introduction of self-assessment, i.e., tax declaration is considered tax assessment in which taxpayer determines tax liability and pays directly when submitting declaration

- Limits types of assessment to two: estimated assessment (to create tax assessment) and additional assessment (to correct tax declaration)

- Statute of limitation: 3 years for regular self-assessment, 5 years after notification of tax evasion

- Explicit provision sharing the burden of proof

- Introduction of unambiguous administrative penalties; i.e., no negotiations between taxpayers and tax administration on level of culpability (negligence, recklessness, and intention to evade tax)

- Clear reference of tax evasion (criminal offense) to the judicial system

- Seizing procedures are brought in line with the procedures of the Public Funds Collection Law

- Clear introduction of ranking order of taxpayer's payments: penalties, delay payments, and tax debt

This included tax benefits and included a schedule that was set to automatically affect amendments to the existing income tax and customs law. Hence, with the passing of the SEZ law, the income tax and customs laws were amended automatically.

\subsection{Simplifying Accounting}

Tax laws require taxpayers to maintain books of accounts to help tax administrators verify the information provided in tax returns. Most tax laws specifically require certain essential books of accounts, leaving it open for taxpayers to maintain records that substantiate income and expenditure-both of capital and revenue-as well as profit and loss and account balances. The accounting requirements are generally less stringent for small and medium enterprises. ${ }^{4}$ Typical books of accounts-ledgers, day books, cash books, purchase books, sales books, inventory, list of debtors and creditors (including their accounts)—may be maintained in electronic form. There is usually

4 See the SME Tax Toolkit, IFC (2008). Also see Terkper (2006). 
a requirement to make these books available for inspection for a certain number of years. This is to permit tax administrators to audit accounts in subsequent years.

To simplify the accounting process, businesses should be required to maintain only a basic set of books and given freedom to decide what other documentation is necessary to substantiate the information provided in their tax returns. Mandating the maintenance of a large number of books of accounts considerably increases businesses' cost of compliance-and may not necessarily help tax administrators. On the other hand, letting businesses decide how to substantiate their declarations encourages them to streamline their accounting even while allowing tax administrators to ensure tax compliance. In case businesses are not able to substantiate the information in their tax returns, tax administrators are then free to levy their best estimate of the tax liability-and interest and penalties, if applicable. In the case of electronic accounts, guidelines should be provided as to what kinds of books need be maintained in paper form as a backup in case the electronic accounts are accidentally erased.

\subsubsection{Tax accounting versus financial accounts and tax simplification}

Every business maintains accounts with the primary aim of providing its owners, shareholders, managers, creditors, and others with correct information about business operations. For tax administrators, however, the accounts must provide them with enough information to help them arrive at the taxes due. The tax administration (TA) usually mandates the manner that accounts be maintained for tax purposes, which may diverge significantly from usual business accounts. For example, general accounting might allow doubtful debts to be deducted, while tax accounting might allow only the exact amount of debt that is bad. Again, depreciation allowances for tax purposes may be different from those used for book purposes. Several other provisions may make the usual business accounts very different from the tax accounts.

The requirement to maintain different accounts imposes additional costs on business. One reform option is to make financial accounts closer to tax accounts, while another is to make tax accounts closer to financial accounts. A third option is to integrate both accounting systems into a common system. Another line of thinking is that these two accounting systems should be treated quite independently.

In the interest of simplification, it is helpful if tax accounting rules allow businesses to derive taxable income from the financial accounts through appropriate reconciliation. This means that businesses can maintain one set of accounts and derive taxable profits from the book profits by adding back deductions that are not allowable under the tax laws, such as: 
- Depreciation deductions according to the books

- Income tax

- Capital expenses deducted, if any (and only amortized value if allowed).

From this, deductions that are allowable under the tax laws can then be reduced, such as:

- Special tax deductions allowed under tax laws

- Carry-forward losses

- Tax depreciation.

The divergence between the two accounting concepts is aggravated by increasing complexity in the tax laws (for example, the provision of special deductions) and by the tendency of financial accounting to move away from taxable profits (for example, the treatment of contingent liabilities). This divergence is unlikely to be reversed in the short term. The goal is to minimize the differences and make it easy for businesses to derive taxable income from their regular accounts. One implication of this divergence is that book profits-as declared to shareholders in the case of corporations-are significantly higher than the taxable profits. Tax authorities imply that the corporation is indulging in tax avoidance and in many cases levy a minimum tax that is based on the book profit. In many cases, these minimum taxes can then be credited against tax to be paid in subsequent years. This makes the reconciliation of the taxable profits and book profits extremely complicated. Such complications in the tax system make it difficult for both businesses and tax authorities to determine the correct taxable profits.

\subsection{The Importance of Considering Tax Administration When Designing Policy}

Any initiative in the design of a good tax policy could fail at the door of the TA. While tax policy can be appropriately set to minimize the burden that the tax system imposes on business, this could be completely undermined by a poor TA. This is especially true in developing countries, where administrative constraints, corruption, and weak institutions impose substantial costs on business. In such cases, improving administration within the existing tax policy parameters could, on its own, substantially reduce the business cost of complying with taxes. A good policy initiative would make sure that the tax rates are reasonable and the tax is designed in a manner that is simple and easy to comply with, even while being easy to administer by tax authorities. The role of tax authorities in tax simplification is analyzed in detail in chapter 5 . 


\section{Further Guidance}

- Thuronyi, Victor. 1996. "Tax Law Design and Drafting." Chapter 3, Drafting Tax Legislation.

- Terpker, Seth. 2007. "Some Tax Accounting Issues and options for SMEs." Tax Notes International 45 (2) January 15. 


\section{Chapter 5: Tax Administration Simplification (Reorienting the Tax Authority)}

\section{CHECKLIST OF GOOD PRACTICES}

$\checkmark$ Prepare detailed process maps of all administrative functions

$\checkmark$ Remove redundant processes, combine others, and retain only those that improve compliance rates

$\checkmark$ Categorize administrative functions by taxpayer type and cater to the needs of taxpayers accordingly

$\checkmark$ Adopt a unique taxpayer identification number that is common across tax types and nontax agencies

$\checkmark$ Provide multiple ways for taxpayers to pay and file their taxes

$\checkmark$ Maintain electronic taxpayer accounts that are reported automatically without burdening the taxpayer to provide proof

$\checkmark$ Withhold taxes only to the extent that its benefits outweigh its additional compliance costs

\subsection{What a Tax Administration Should Do}

Before the role of the tax administration (TA) can be outlined, it is important to define its scope. ${ }^{1}$ The TA includes both private and public sector activities-including the activities of many different units in the public sector. These include the tax ministry; tax departments (the focus of this chapter and what might be termed TA in the narrow sense); independent auditing, anticorruption, and legislative oversight bodies; third parties to whom tax activities are outsourced (such as banks, tax withholders, tax farmers, and even tax-form printers); civil courts, arbitrators, tribunals, police, and the criminal justice system (to the extent that they deal with tax matters); tax practitioners and their associations and organizations; and taxpayers' associations.

1 This and the next paragraph are based on Das-Gupta (2006c). 


\section{BOX 5.1 Major TA Functions}

1. Taxpayer information and education

- Information pamphlets and publications of tax laws, including administrative laws and key procedures

- Online taxpayer website

- Other publicity

- Helplines and helpdesks

- Advance rulings and taxpayer queries

- Taxpayer feedback and liaison with citizens' associations

- Liaison with tax representatives and their associations

2. Taxpayer facilitation

- Tax registration facilitation and assignment of taxpayer numbers

- Tax clearances and permissions facilitation

- Returns filing by taxpayers, withholders, and third parties

- Tax payment facilitation

- Trade facilitation and electronic data interchange (customs)

- Administrative grievance and complaint redressing channels

- Tax payment facilitation (nondelinquent taxes)

- Refunds management

- Helplines and helpdesks

- Monitoring taxpayer compliance costs

3. Taxpayer compliance

- Identification of nonfilers and followup

- Control of registration and taxpayer number fraud

- Maintenance of the taxpayer master file

- Collection and processing of withholder and third-party information reports

- Tax return tracking of stop filers

- Warehousing (commodity and trade taxes)

The focus of this chapter is limited to tax departments, or TA in the narrow sense of the term. Before answering the question, "What should a TA do?" it is useful to consider why a TA is even necessary. In the case of informed and honest taxpayers, tax administrators' only job would be to make it easy to pay taxes. (Indeed, in many countries, the actual collection of voluntary payments for the fiscal treasury is not a function assigned to the TA.) But because real-world taxpayers are neither fully informed nor always honest, the TA's major goals are to (i) educate taxpayers about taxes and their tax obligations, (ii) help honest taxpayers comply, and (iii) enforce compliance on tax evaders. Thus, the three major TA responsibilities are to provide taxpayer information and education; taxpayer services and facilitation; and tax enforcement, ensuring that taxes are paid to the government in accordance with the law. 


\section{BOX 5.1 (continued)}

- Border checkposts (commodity and trade taxes)

- Information and tax-return processing

- Tax assessment including tax audits

- Penalty proceedings and imposition

- Settlement and compounding of offences

- Representation of revenue interest in tax appeals and tax prosecutions

- Giving effect to appeal decisions

- Tax-fraud investigation

- Tax raids

- Delinquent tax collection

- Nonpayment enforcement

- Taxpayer current account maintenance

- Tax clearances and sailing permits

- Information and collection cooperation with other jurisdictions

4. Important internal functions

- Internal auditing

- Follow-up actions on internal and external audit reports

- Personnel policies-recruitment, transfers, promotions, superannuation, and termination

- Training

- Tax office and equipment maintenance

- Maintenance of taxpayer and third-party records

- Tax IT and reengineering of procedures and databases

- Operations planning

- Operations management

- Outsourcing and external supplier control

Source: Authors

Note: Activities requiring interaction between the TA staff and taxpayers or related third parties are in bold.

Contrary to popular belief, the job of a TA is not merely to raise a lot of revenue. Its function is to implement tax laws effectively and efficiently. In other words, the TA must raise as much revenue (but only as much) as the tax laws prescribe, and discharge its duty at the least possible social cost. ${ }^{2}$ Also contrary to popular belief, the primary responsibility of a TA is not enforcement. Informing, educating, and assisting law-abiding citizens with their tax obligations are equally important.

2 Three points should be noted: (i) the commonly used measure of TA (in)effectiveness is the tax gap; (ii) TA efficiency should be distinguished from economic efficiency-the latter refers to the nonwasteful and appropriate use of a nation's resources; and (iii) the revenue-to-social-cost ratio is, conceptually, the correct measure of TA efficiency. Since the tax department forms only a small part of the TA, the ratio of its budgetary cost to the revenue collected does not in any way reflect the TA's efficiency. An increase in the budgeted cost-to-collection ratio may, in fact, reflect decreased TA efficiency if this is achieved by reducing some TA duties and instead shifting the burden of tax obligations onto the taxpayers or by decreasing taxpayer services. 
Gill (2000) and the Organisation for Economic Co-operation and Development (OECD 2006) provide excellent reviews of the functions and activities of TAs. Box 5.1 lists key TA functions. Although taxpayer types are not categorized here, it must be noted that administrative functions are most efficient when targeted to different types of taxpayers (small or large; resident or nonresident; individuals, corporations, and other entities).

\section{Box 5.2 Tax Process Simplification using Process Maps}

Process Mapping is a method for depicting a process, material, or information flow in a diagrammatic form. The figure below is an example of a process map for issuing a Taxpayer ID number in a Large Taxpayer Unit in Sanaa, Yemen.

FIGURE 5.1 Example of a Process Map

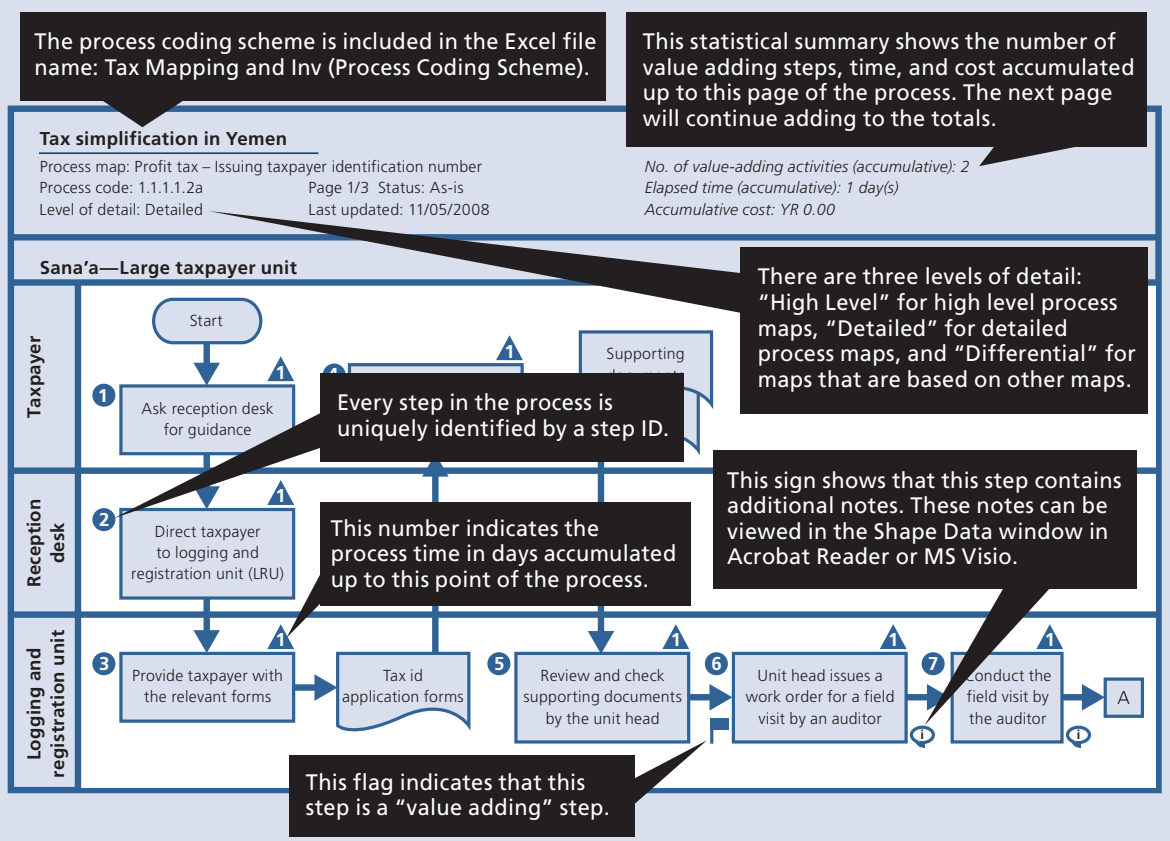

In the case of tax administration, process maps are extremely useful for the following:

- To simplify the processes in the current state

- To develop standard procedures, employee manuals, and training courses and executive regulations

- To facilitate automation of processes

- To onboard new team members (e.g., advisors, consultants, project officers/analysts) without burdening the client

- As a benchmarking tool (simplified vs. as-is maps)

As a result, they could assist the tax administration to strengthen/modify/remove processes with the dual aim of making them more efficient and reducing the time it takes to directly interact with taxpayers. This reduces compliance costs for taxpayers without reducing the ability of the tax administration to ensure tax compliance and collect taxes.

Source: Husam Al-Sharjabi (2009), Apex Consulting. 


\subsubsection{Tax design permitting simplified $\mathrm{TA}^{3}$}

Some key design features of taxes that permit simplified TA are briefly reviewed below.

Silvani and Baer (1997) note that a tax system with few taxes, a limited number of rates for each tax, limited exemptions, and a broad base has proven, in the context of many developing countries, to be much easier to administer and to result in higher compliance levels than a complex tax system. ${ }^{4}$

Few taxes leads to low economic efficiency and equity costs in addition to directly lowering TA costs. Few rates of tax, in the case of taxes on goods, reduces the possibility of noncompliance through misclassification. This decreases the information verification burden of tax determination (TD). ${ }^{5}$ For income tax, progressive rates may induce firms to split into taxable entities below their economically efficient size, leading to inefficient use of resources and resulting in firms that cannot take advantage of economies of scale.

An important goal of TA architecture design is to make the tax administration more responsive to the needs of the taxpayers. This can be done by limiting unessential contact with taxpayers in the performance of their functions and by acting efficiently to address taxpayer requirements.

Few exemptions limits the need to verify case-by-case compliance with the conditions under which exemptions are granted. TA costs increase and TA becomes complex if the tax system is used to achieve nonrevenue objectives. Besides a narrower base, reduced equity, and price distortions, differential treatment of entities greatly increases the TA information requirements, increases opportunities for misreporting, and complicates tax compliance requirements for taxpayers and third parties. Tax concessions for nonrevenue objectives should be used very selectively and only after comparing their effectiveness with alternative (expenditure, subsidy, or regulatory) instruments that can potentially serve the same objectives.

Broad bases can be justified by the indirect information saving due to lower noncompliance opportunities and incentives. With little exclusion from the tax base, tax evasion or avoidance (by claiming to belong to an excluded category) becomes

\footnotetext{
3 This section is largely based on section 3 of Das-Gupta (2006c).

4 Silvani and Baer (1997). Also consider Wallschutzky (1989): (i) keep the tax laws as simple as possible; (ii) aim for a global tax with few exemptions, credits, rebates, or deductions; (iii) do not try to use the tax system to achieve too many social and economic goals; (iv) continually monitor the tax system; (v) concentrate on basic tasks such as the collection of tax at source and an identification number system; (vi) do not collect more information than can be processed; (vii) actively encourage good record-keeping; and (viii) aim for self-assessment as a long-term goal.

5 For a recent evaluation of the impact of misclassification on customs revenue, see Fisman and Wei (2004).
} 
harder. Furthermore, for a given revenue requirement, the tax rates can usually be lower than with a narrow tax base. This reduces the incentive not to comply-further widening the base-because expected gains from noncompliance are directly related to potential tax savings.

It should be borne in mind that there is a trade-off between administrative simplicity and the equity and efficiency of tax design. A simple example vividly illustrates this trade-off: Imagine a ruler of an ancient country instructing the army, "Get me as much money as you can from my subjects" (the tax design). The army then carries out the ruler's bidding (TA). The example illustrates how tax simplification can be carried too far in the pursuit of administrative simplicity. The use of presumptions and simplified regimes for the difficult-to-tax are important modern examples of administrative simplification at the expense of tax equity and economic efficiency.

The use of presumptions is unavoidable if taxes are to be administratively feasible. ${ }^{6}$ All things being equal, presumptions are more likely to be efficient if the TA's need for information to determine or verify normal taxes supersedes the need for tax equity. An example would be the use of depreciation schedules. Another reason for the use of presumptions is that it permits immediate use for assessments in cases where normal TD procedures require information not immediately available, or where the TA's future ability to collect taxes owed is uncertain (for example, withholding taxes).

Selective exemptions from normal tax compliance obligations for the hard-to-tax (including the informal sector) also make for a simplified TA, at the possible expense of tax equity. Expenditure by the TA to chase after meager revenue gains from the hard-to-tax is likely to be wasteful. ${ }^{7}$

\subsubsection{Front- and back-end activities}

Activities that require the interaction of the TA with taxpayers or related third parties are sometimes referred to as "front-end TA activities." TA activities that wholly or partly require TA interaction with taxpayers or their representatives are listed in bold in box 5.1.

For front-end activities, key performance criteria for information or facilitation activities (see box 5.1) are somewhat different from those activities related to

\footnotetext{
6 Presumptions are pervasive even in developed countries. Examples are tax-depreciation schedules; fixed schedules for entertainment deductions and ceilings or fixed allowances for other deductions; alternative minimum-tax regimes for corporations; and turnover-based simplified tax regimes in lieu of the value-added tax (VAT) for small firms. See the discussion in Tanzi and Casanegra de Jantscher (1987); Sadka and Tanzi (1993); Rajaraman (1995); and Slemrod and Yitzhaki (1996).

7 Theoretical support for this position is in McLaren (2003). Terpker (2003) points to an inevitable caveat: Resources expended on enforcing compliance among the hard-to-tax may optimally be more than pure revenue; efficiency considerations dictate that tax morale or compliance by others is adversely affected by the existence of lightly taxed sectors. Such inefficient use of resources is less costly in developed countries that have smaller proportions of hard-to-tax taxpayers, according to the preliminary evidence in Alm and Martinez-Vazquez (2003).
} 
compliance control. It is important for front-end activities concerned with taxpayer information and facilitation to be accessible, convenient, responsive, quick, and easy to understand. Several countries have, for instance, employed taxpayer telephone and e-mail helplines. Accessibility in this context requires that phone numbers and e-mail addresses be easy to locate. For example, a single source for all "citizen services" in a country is one possible way to achieve this. To take another example not within the purview of helpdesks, action initiated by the TA such as the mailing of notices, reminders, or return forms with basic information already filled out, is also important. Convenience is furthered by good timing, the overcoming of language barriers, and officials trained to help poorly informed taxpayers identify their concerns. Furthermore, helpdesks need to plan to deal with peak volumes at specific times such as immediately before the filing deadline. Responsiveness includes, importantly, suggestions for follow-up action or responses on the part of the TA if warranted (for example, by sending information brochures or forms). That all instructions need be concise and easy to understand needs no elaboration.

An important dimension of front-end activities involves the taxpayer's visits to tax offices and face-to-face interactions between the taxpayers and TA officials. It is often the case that the TA offices in developing countries are poorly designed and inconvenient for taxpayers to visit. They also often mix front- and back-end activities. In designing tax offices, a number of criteria are important: convenient location (so that the majority of taxpayers do not have to go far out of their way to visit the tax office), convenient hours of operation that are well advertised, adequate staff to deal with common high-volume client requests, basic amenities (chairs, drinking water, and so on), a single first-access point (or receptionist) who can identify the relevant official for the visitor to see, and, ideally, meeting rooms or kiosks where the official can meet the taxpayer. Even if kiosks are not possible (say, due to space constraints), office design should seek to minimize taxpayer movements for highvolume requests (such as certain clearances, filing documents or making payments, information requests, and registration of taxpayer number applications).

Security and potential corruption problems also need to be taken into account for front-end activity. For example, the single access point can serve to record taxpayer visits and the official(s) the taxpayer interacts with. Second, face-to-face interaction with several tax officials, including officials responsible for compliance control of the taxpayer, is minimized. A taxpayer waiting area and the kiosks help ensure that taxpayers cannot easily gain access to tax records and make data and document security hard to breach. TAs with tax offices where taxpayers have access to sensitive areas are a sign of poor office design. ${ }^{8}$

\footnotetext{
8 Other issues include security of the TA employees against potential threats from angry citizens and vandals. The office structure described in the text is clearly for local offices with, at least, say, seven or more staff. This suggests a trade-off between more small offices to ensure accessibility and sufficiently-sized tax offices to allow pursuit of economies of scale and anticorruption objectives.
} 
For other front-end activities such as tax audits, customs warehouses, and border checks, while taxpayer compliance costs and, therefore, performance indicators such as those discussed above should be given due weight, ensuring effective compliance verification and control must be given greater importance.

A second aspect of the division between front- and back-end activities arises from the distinction between administrative policy and procedures on the one hand and taxpayer-related "field" operations on the other. For example, consider tax auditsselection of taxpayers for audit, audit strategy, and audit effectiveness evaluation are aspects of tax audits that do not require taxpayer interaction, in contrast to the actual conduct of audits. The traditional "line-and-staff" division in most organizational designs allows for the separation of these front- and back-end functions. This is discussed further below.

Back-end activities also encompass taxpayer-related activities that do not require direct interaction with the taxpayers and internal functions. Clearly, for these activities, taxpayer interaction will not play a role in measuring their effectiveness or efficiency. Selected compliance-related activities are discussed later in this chapter.

\subsubsection{Computers and information technology}

Information technology (IT) is enormously useful in improving the effectiveness and efficiency of the TA in a variety of ways. Given the rapid innovation in IT, any discussion that tries to lay out general principles will inevitably become quickly dated? Common current applications of IT in the TA include online databases and information repositories, communications infrastructure, data mining, management information systems (MISs), and artificial intelligence applications. ${ }^{10}$

For developing countries that still rely, partly or wholly, on procedures and systems that are not IT-enabled, the cost efficiency and effectiveness of introducing IT is beyond doubt. A key question relates to the sequencing of areas in which to introduce IT systems and how to educate (typically older) staff unfamiliar with IT and possibly fearful of job displacement. In this situation, one area that appears to face little resistance is payroll processing, especially if the existing manual payroll system

\footnotetext{
9 For an example of a dated discussion, see Bagchi, Bird, and Das-Gupta (1995). For more recent discussion see Engelschalk (2000) and Bird and Zolt (2008). Also see Bird (2007).

${ }^{10}$ These categories include several applications that may not be obvious. For example, online databases may include a searchable case law database; information repositories can include tax assessment records searchable by responsible tax officials to establish accountability; communications infrastructure can include global positioning system-enabled hand phones for tax and customs fraud investigations or real-time tax payment information from banks; data mining could include intelligent searching of satellite images to locate new properties not within a property tax net; management information systems (MIS) could be used to compile information on divisional or individual performance comparisons; artificial intelligence applications could include decision-making assistance for, say, pursuing a tax appeal, with the application based on data mining of success and failures of past appeals.
} 
is subject to errors and delays. For taxpayer-related IT, initial outsourcing (perhaps to another government department) of selected systems until existing employees can be retrained, relocated, or reassigned is another low-resistance strategy. Among such initial systems are taxpayer services, taxpayer registration or tax number assignment, the taxpayer or withholder master file, and returns receiving-in that order. Third, external pressure for difficult-to-outsource functions, such as tax payments accounting from the treasury, can prove useful.

Leaving aside these initial problems, a general strategy of automating taxpayerinformation services followed by taxpayer and related databases before embarking on more sophisticated systems is recommended.

The role of Information Technology in Tax Simplification cannot be underestimated. It is in some cases the necessary condition for the implementation of Tax Simplification Solutions. For example, allotting unique tax ID numbers, maintaining tax accounts, crediting taxpayers' accounts for taxes paid, implementing a risk-based audit system, and so on are extremely difficult without a sound Information Technology infrastructure.

One advantage of IT-enabled taxpayer databases is the availability of off-theshelf software and consultancy services for several basic taxpayer functions, including registration, the compiling of the master file, returns receipt, and the taxpayer current account. Given the fair degree of similarity of these procedures across countries, specially commissioned, customized software generally has cost disadvantages and teething problems that outweigh their possible benefits. An important advantage is the likely attention that vendors of off-the-shelf products will pay to data security. A second advantage is the likely availability of periodic systems upgrades.

For in-house hardware, preparation of specifications is now a specialized function for which commercial (or government) expertise should be employed. Options for future service expansion and a degree of systems modularity to enable replacement by improved systems are recommended as a key part of the specifications.

Other important issues are security and the related issue of networking. Database security is best achieved by the use of standalone systems with adequate access security and standalone backup copies of databases. Standalone systems, however, cause database fragmentation if the TA has more than one office. Furthermore, IT-enabled administration has greatly increased communication efficiency and the ability to process and share data from an integrated database. Integration permits a variety of coordinated activities (not possible in TAs that rely on manual systems), greatly enhancing their effectiveness. Nevertheless, there is always the danger of unauthorized access and violation of taxpayer confidentiality. For this issue, possibly the best advice is to adopt the latest available security technology and to ensure that TA staff 
are made to strictly follow security procedures, even at the risk of some loss in cost efficiency and effectiveness. ${ }^{11}$

Last, but not least, reengineering business processes and restructuring the TA organizations are crucial for successful IT introduction. As a guiding philosophy, the phrase "don't automate the paper: rebalance, redesign, and eliminate redundant processes" is apt. ${ }^{12}$ The major points to keep in mind are that manual operations have a much smaller least-cost scale when compared with IT-enabled processes to replace them. This suggests a greater degree of centralization of routine operations such as return filing and maintaining the taxpayer master file. Other organizational implications also exist. Even more important is the need to thoroughly overhaul and reengineer most of the business processes associated with the functions listed in table 5.1. ${ }^{13}$

\subsection{Organization of the Tax Administration Authority}

To ensure TA effectiveness and efficiency, several organizational issues need to be planned. Key issues include management autonomy, external reporting and accountability, management flexibility and decision powers, internal organization, and outsourcing of selected functions. These will be discussed in more detail.

\subsubsection{Management autonomy ${ }^{14}$}

This has been a much-debated topic in recent times. At one extreme, countries follow the traditional practice of the TA being just another government department in the ministry responsible for raising revenue. In recent times, several developed and developing countries have carved out separate revenue boards or independent TAs, often with statutory status. The main arguments for this are that it affords the TA flexibility in hiring and salary practices and the ability to focus on revenue-collection without having to follow standard civil service norms and practices. One key argument for this is that TA effectiveness and efficiency are relatively easy to define and so can be easily linked to TA budget and staff compensation rates. A second argument points to the TA's specialized requirements for IT, legal, and accounting professionals, who typically command high salaries—well above those of typical civil servants. The third argument stresses the need to keep sensitive information, such as taxpayer records, confidential. Bird (2007) concludes that the experience to date of

\footnotetext{
11 The importance of good security is underlined by HM Revenue and Customs' recent loss of the sensitive electronic records of 25 million mainly high net worth taxpayers, with the possibility that they fell into the wrong hands. See British Broadcasting Corporation (BBC 2007) and Thomson (2007). Britain and Japan are examples of poor IT implementation in developed countries.

12 The phrase was coined by Craig Neal of the World Bank.

${ }^{13}$ Case studies of IT introduction and concurrent organizational restructuring and business process reengineering (BPR) are provided by the Commonwealth Association of Tax Administrators (CATA 2007).

${ }^{14}$ For further discussion, see Jenkins (1994); Devas, Delay, and Hubbard (2001); Estela (2001); and Taliercio (2004). For an assessment, see Bird (2007).
} 


\section{BOX 5.3 Lessons on Computerizing Tax Administration: The Case of India}

India embarked on a program of computerization in 1982, but it was only in 2003 that some level of sophistication was achieved with the introduction of electronic filing (e-filing). Some of the lessons learned could be useful to any efforts toward computerization.

In 1983, a taxpayer identification number (TIN) was developed called the permanent account number (PAN). Its purpose was primarily to process tax payments made at banks to ensure that an adequate level of reporting of the tax collections was made to the treasury. When a taxpayer made a tax payment in the bank, (s)he had to fill out the tax-payment form in quadruplicate. One copy was returned to the taxpayer, one was retained by the bank, one was sent to the treasury, and the last copy was sent to the computer center of the tax department. Details from the last copy were then entered into the computer to serve as a record of the tax payment. The tax offices were then sent reams of computerized tax payment records, which were consulted when refunds were paid to verify whether the original tax was indeed paid. The program for computerization never really progressed beyond this basic role.

A second attempt was made in 1994 with a new tax ID number and the creation of several computer centers around the country. The tax department embarked on a computerization program, with the goal of having all tax returns entered into an electronic form. But the strategy turned out to be ill-conceived, with efforts made to automate existing processes ("automating the paper") without reengineering the department to make the best use of computerization. The situation was complicated primarily due to resistance from staff, who preferred direct contact with the taxpayers and feared being banished into computer centers to function as data-entry operators. The concept of front office and back office was never adopted. Taxpayers provided paper forms to their tax assessor for tax IDs and tax returns, who in turn keyed the data into the computer. Most tax offices were poorly networked to the national tax computer network and it was not uncommon for work to be held up by power outages, network downtime, and crashing computers.

The government tried to popularize the adoption of taxpayer identification numbers (TINs) by mandating that certain transactions be accompanied by a tax ID number. But with a poor computer system, taxpayers went from office to office in the hope of getting a tax ID number in order to buy a house, register a vehicle, and so on. This resulted in the issuance of multiple tax ID numbers. As a result, the system went into near collapse by 2002 . Some efforts at a centralized processing of tax returns of salaried taxpayers have had partial success, Mumbai's being the best example. In 2003, the government outsourced the allotment of tax ID numbers and the issuing system stabilized a little. In 2004, it was mandated that all tax returns of corporations had to be filed online. Despite the initial hiccups, this effort was quite successful. The Income Tax Department (ITD) now is increasingly using third parties for e-filing. But the Indian ITD never really recovered from these initial setbacks. It took more than 20 years for the Indian ITD to reach its current status.

Source: Author's research.

developing countries with autonomous TAs is mixed; much depends on the precise nature and extent of the autonomy reforms.

\subsubsection{External reporting and accountability}

Whatever the degree of management autonomy, institutions that ensure accountability to the TA are vital. Competent external oversight is perhaps of greater importance if the TA is autonomous. Typically, this implies parliamentary oversight supported by regular financial and performance audits by the country's supreme audit institution 
or equivalent. Other channels that may exist are independent taxpayer feedback and anticorruption institutions, which can provide important inputs for effective oversight. Oversight should focus mostly on the TA's effectiveness in ensuring timely collection of dues, an acceptable tax gap, fair treatment of taxpayers, low taxpayer compliance costs, and possibly the integrity of the TA staff. On the other hand, low administrative costs for tax collection need not be a direct focus, especially if the budget of the TA incorporates incentives for the TA to function efficiently.

\subsubsection{Management flexibility and decision powers}

A general strategy to foster performance-oriented TA is outlined in table 5.1. The important point suggested by the strategy is that performance, once it is properly defined and adequately measured, requires management flexibility to allow the TA to focus on achieving its goals unhindered and to link incentives to performance delivery. This implies that senior TA officials should have the freedom to choose an appropriate organizational structure and assign responsibilities to the organizational units. Furthermore, managers should have the freedom to acquire and deploy physical resources and the manpower necessary to carry out their assigned responsibilities effectively, subject only to external oversight to ensure no malfeasance or abuse of powers. ${ }^{15}$

As table 5.1 shows, this prescription is part of an interlocked package: managers can be left free to do their assigned jobs provided they are motivated (via positive and negative incentives) to pursue the same mission as the TA. In practice, only a few TAs reach this ideal, so other checks and balances are typically deployed (ombuds-

TABLE 5.1 Institutions for performance orientation ${ }^{16}$

\begin{tabular}{|l|l|}
\hline Objective & Operational implementation \\
\hline Clarity of goals & $\begin{array}{l}\text { Mission and vision statements, citizen's charter, medium-range } \\
\text { modernization plan }\end{array}$ \\
\hline $\begin{array}{l}\text { Measuring goal achievement } \\
\text { or performance }\end{array}$ & $\begin{array}{l}\text { System of performance indicators reflecting effectiveness, } \\
\text { efficiency, and citizen's service quality to foster achievement } \\
\text { of the administration's mission; quantitative assessment of a } \\
\text { modernization plan }\end{array}$ \\
\hline Enabling performance & $\begin{array}{l}\text { Operational autonomy for tax departments; organization by } \\
\text { taxpayer segments and functions }\end{array}$ \\
\hline Communicating performance & $\begin{array}{l}\text { Annual reports to government on administrative effectiveness } \\
\text { and efficiency in delivering performance; performance reports } \\
\text { for individuals, functional units, and field offices based on } \\
\text { performance indicators }\end{array}$ \\
\hline $\begin{array}{l}\text { Rewarding and motivating } \\
\text { performance }\end{array}$ & $\begin{array}{l}\text { Administration budgets linked to performance; positive and } \\
\text { negative individual- and unit-performance incentives }\end{array}$ \\
\hline
\end{tabular}

\footnotetext{
${ }^{15}$ See OECD (2006), table 5, for a summary of country practices relating to management flexibility.

${ }^{16}$ Adapted from Apte and Das-Gupta (2002).
} 
men, taxpayer-grievance and dispute-resolution channels, management inspections and monitoring), despite an accompanying risk of decreased TA efficiency.

Another issue that needs to be addressed here is the power legally vested in TAs visà-vis taxpayers and other citizens. There is a trade-off between important informationgathering on the one hand and the extent to which taxpayers' right to privacy is respected. Since information collection also encompasses the power to enter taxpayers' premises and conduct interrogations, there is also the issue of safeguards against harassment by tax administrators. ${ }^{17}$ Of special importance is the TA's power to obtain information about taxpayers from banks and financial institutions. Country practices of granting power to TA officials — and the nature of safeguards — vary widely, though most countries grant TAs wide-ranging powers. ${ }^{18}$ One common requirement is to require approval by a designated senior TA official or via a prescribed channel (for example, judicial warrants) for the most intrusive or onerous TA information-gathering procedures.

\subsubsection{Internal organization}

There are three important areas of TA responsibility that need to be considered when designing efficient internal TA structures: different taxes, different functions, and different taxpayers. Table 5.2 summarizes major organizational options. A discussion of

TABLE 5.2 Organizational options for TAS

\begin{tabular}{|c|c|c|c|c|}
\hline Model & $\begin{array}{l}\text { First } \\
\text { level in the } \\
\text { hierarchy }\end{array}$ & $\begin{array}{l}\text { Second } \\
\text { level in the } \\
\text { hierarchy }\end{array}$ & $\begin{array}{l}\text { Third } \\
\text { level in the } \\
\text { hierarchy }\end{array}$ & Comments \\
\hline Type of tax & $\begin{array}{l}\text { Separate } \\
\text { units for } \\
\text { major groups } \\
\text { of taxes }\end{array}$ & By function & $\begin{array}{l}\text { (a) By taxpayer } \\
\text { type OR } \\
\text { (b) By taxpayer } \\
\text { location }\end{array}$ & $\begin{array}{l}\text { Multiple, functionally } \\
\text { organized TAs; waste } \\
\text { resources by duplicating } \\
\text { functions; high compliance } \\
\text { costs for taxpayers owing } \\
\text { many taxes }\end{array}$ \\
\hline Functional & By function & $\begin{array}{l}\text { By taxpayer } \\
\text { type }\end{array}$ & By tax & $\begin{array}{l}\text { Coordination problems } \\
\text { across functions; limited } \\
\text { flexibility to address special } \\
\text { taxpayer needs }\end{array}$ \\
\hline $\begin{array}{l}\text { Taxpayer } \\
\text { segment }\end{array}$ & $\begin{array}{l}\text { By taxpayer } \\
\text { type }\end{array}$ & By function & Usually absent & $\begin{array}{l}\text { Separate units for large } \\
\text { and small taxpayers }\end{array}$ \\
\hline $\begin{array}{l}\text { Single-officer } \\
\text { system }\end{array}$ & $\begin{array}{l}\text { By major tax } \\
\text { groups }\end{array}$ & $\begin{array}{l}\text { By taxpayer } \\
\text { group (type, } \\
\text { location, } \\
\text { or both) }\end{array}$ & $\begin{array}{l}\text { Most routine } \\
\text { taxpayer-related } \\
\text { functions } \\
\text { entrusted to a } \\
\text { single officer }\end{array}$ & $\begin{array}{l}\text { Prone to taxpayer-tax } \\
\text { official collusion and } \\
\text { corruption }\end{array}$ \\
\hline
\end{tabular}

\footnotetext{
${ }^{17}$ See Bagchi, Bird, and Das-Gupta (1995) and Bird (2007).

${ }^{18}$ See OECD (2006), table 18, for a review of country practices related to information collection powers other than routine powers. OECD (2000) and OECD (2003) make recommendations regarding access to bank information and taxpayer confidentiality.
} 


\section{BOX 5.4 How the Organizational Structures of Revenue Bodies Have Evolved ${ }^{19}$}

Over the last 20-30 years, there has been a clear trend in the way the internal organizational structures of national revenue bodies have evolved.

\section{The Type-of-Tax Model}

The earliest organizational model employed by the TAs was based principally on the "type-of-tax" criterion. This entailed the operation of separate multifunctional departments for each tax that were largely self-sufficient and independent of each other. While this model served its purpose, it was eventually seen to have numerous shortcomings: (i) with its inherent duplication of functions, it came to be seen as inefficient; (ii) it was inconvenient for those taxpayers with multiple tax dealings (for example, businesses), requiring them to deal with different departments on similar issues; (iii) it severely complicated the management of the taxpayers' compliance, with its separate audit and debt-collection functions; (iv) it increased the likelihood of uneven and inconsistent treatment of taxpayers across tax types; ( $v$ ) it impeded the flexible use of staff, whose skills were largely confined to a particular tax; and (vi) it unnecessarily fragmented the overall management of the TA, thus complicating organizational planning and coordination. Faced with these shortcomings, many revenue bodies have evolved their organizational design to one based largely on functional criteria.

\section{The Functional Model}

Under the functional model, staff are organized principally by functional groupings (such as registration, accounting, information processing, audit, collection, appeals, and so on) and generally work across taxes. This approach to organizing tax work was introduced to enable greater standardization of work processes across taxes, to simplify computerization and arrangements for taxpayers, and to generally improve operational efficiency. Compared to the "tax-type" model,

pros and cons of different organizational approaches is given in box 5.4. It should be noted that the typology is not exhaustive. For example, it is conceivable that a "matrix organization" can be introduced with multiple reporting requirements of individual tax officials across any of several dimensions such as taxpayer type, tax, and location. ${ }^{20}$

As box 5.4 documents, OECD (2006) identifies the taxpayer-segment structure as the most appropriate for TAs. This is also the view of the International Monetary Fund's (IMF's) fiscal affairs department, especially with respect to large taxpayers. ${ }^{21}$ Few countries have, as yet, completed the transition to this model.

Two groups require special mention in the context of designing TA organizations. First, the largely successful experience of many TAs with large taxpayer units (LTUs) suggests that their establishment is important for effective administration. Large taxpayers generally comprise less than 1 percent of all taxpayers in a country but typically contribute over 50 percent of tax revenues. For this reason, special units to deal with large taxpayers are of great importance to revenue collection. Additionally, large taxpayers are

\footnotetext{
19 This box is reproduced with permission from the OECD (2006). See also Ebrill and others (2001), chapter 12.

${ }^{20}$ See OECD (2006), boxes 3, 4, and 5, for information on the organization of the U.S., Australian, and South African TAs with particular reference to large taxpayer units.

${ }^{21}$ See Baer, Benon, and Rivera (2002); and McCarten (2004).
} 


\section{BOX 5.4 (continued)}

this model was perceived to offer many advantages and its adoption has facilitated many developments aimed at improving TA performance (for example, providing single points of access for tax inquiries, unified system of taxpayer registration, common tax payment and accounting approaches, and more effective management of the tax-audit and debt-collection functions). But this model too is not without its weaknesses-fragmentation by function can lead to poor/ inconsistent service while standardization (such as a "one-size-fits-all" approach) may not be appropriate in some areas of the revenue administration work, given the myriad behaviors and the varying attitudes to tax compliance to be addressed.

\section{The Taxpayer-Segment Model}

A more recent development among a small number of developed countries has been to organize service and enforcement functions principally around segments of taxpayers (for example, large businesses, small and medium businesses, employees, and so on). The rationale for organizing these functions around taxpayer segments is that each group of taxpayers has different characteristics and tax-compliance behaviors and, as a result, presents different risks to the revenue. In order to manage these risks effectively, the revenue body needs to develop and implement strategies (such as law clarification, taxpayer education, improved service, more targeted audits, and so on) that are appropriate to the unique characteristics and compliance issues presented by each taxpayer group. Proponents of the "taxpayer-segment" type of structure contend that grouping key functional activities within a unified and dedicated management structure increases the prospects of improving overall compliance levels.

While application of the "taxpayer-segment" model is still in its early stages of use, many countries have partially applied this approach by creating dedicated, large taxpayer divisions and units.

Source: OECD 2006.

typically more sophisticated and knowledgeable than others, having access to expert advice in the complexity of their tax affairs, particularly in relation to cross-border activity. LTUs are usually responsible for the registration, tax accounting, tax auditing, collections, and taxpayer services for all major taxes payable by these taxpayers.

In monitoring large taxpayers, an important issue is what to do in the case of multiple places of business - should there be one LTU dealing with all the tax affairs of a large taxpayer or many responsible for different places of business? A key requirement is that one LTU should maintain all the tax records of a given large taxpayer to avoid fragmentation. For routine activity (such as tax payments, routine inspections, verification of eligibility for clearances, and so on), local tax offices can act as the agent of the concerned LTU to save costs, while ensuring that all records are copied to the LTU. For tax audits, however, a single audit team for all offices is to be advocated in accordance with a coordinated audit plan. As with normal commercial audits by external auditors, this prescription presents no operational difficulties even if it requires careful coordination. ${ }^{22}$

\footnotetext{
${ }^{22}$ Dedicated software and field audits at the taxpayers' premises greatly facilitate such audits as they permit information to be recorded and combined for analysis. But even if the procedures are manual, effective audits are still possible.
} 
Small taxpayers also need special consideration. They typically have limited tax knowledge and may otherwise lack the knowledge and sophistication to comply with normal income and commodity taxes. Compliance cost studies in various countries have found, furthermore, that the compliance costs relative to tax dues of small taxpayers tend to be high. ${ }^{23}$ Given the potential cost burden and also the likely importance of small businesses in an antipoverty strategy, the best course of action is to exempt the smallest from all tax obligations. Small units that are, on balance, felt to be worth taxing utilize simplified commodity tax regimes and presumptive income taxes in many countries. ${ }^{24}$

It should be recalled that front- and back-end functions also have implications for the TA's organizational design.

In choosing an appropriate organization design, several TA and country characteristics should be considered: ${ }^{25}$

- The general level of literacy and the extent of penetration of modern accounting practices in the country. Recordkeeping requirements for literate taxpayers can be greater, thus reducing the need for TA-taxpayer interaction. This implies a smaller taxpayer service network.

- The size of the informal sector and other hard-to-tax groups. If these are large, greater TA attention needs to be devoted to the nonfilers and to the administration of simplified regimes.

- The spread or concentration of taxable activity. This will influence the deployment of TA resources across different locations.

- The extent to which TA operations are automated. After automation, consolidation to achieve scale economies is to be advocated. ${ }^{26}$

- The importance of globalization and cross-border economic activity. If there is extensive cross-border activity, greater attention needs to be paid to safeguard revenue via dedicated units and procedures. ${ }^{27}$

For developing countries and countries in transition, an additional consideration is the extent to which citizens have a "tax culture" and their familiarity with the taxes. For most developing countries, lack of a tax culture will imply that TAs pay greater attention to taxpayer education.

\subsubsection{Outsourcing select functions}

As a general rule, the TAs should seek to outsource activities that can be done more cost efficiently, speedily, or externally, if no confidentiality issues arise. Historically,

\footnotetext{
${ }^{23}$ For a study of cost-of-compliance surveys, see Evans (2003). See also Chattopadhyay and Das-Gupta (2002).

${ }^{24}$ On presumptive taxation of the hard-to-tax, see Bird and Wallace (2004).

${ }^{25}$ For further discussion, see Vazquez-Caro, Reid, and Bird (1992).

${ }^{26}$ See Martinez-Vazquez and Timofeev (2005) for a discussion of centralized versus decentralized TA.

${ }^{27}$ For an instructive developed country case, see Auditor General of Canada (2007).
} 
there have even been outsourced TAs. ${ }^{28}$ In modern TAs, some functions are outsourced to banks; the main outsourced activities include tax collection via withholding and elements of taxpayer education such as making rules and forms available. Other outsourced activities include requirements for larger taxpayers to have their tax returns audited by accountants (as in Mexico), issuance of taxpayer numbers (as in India), introducing IT-enabled procedures (such as electronic filing of returns, besides routine office maintenance), and the collection of delinquent taxes to private debt-collection agencies (United States). Outsourcing can be to third parties in the private sector or other government departments (or additional compliance requirements can, in effect, "outsource" responsibilities to taxpayers). The general principle is that activities should be outsourced if this saves (social, including compliance) costs without materially impairing TA effectiveness or placing taxpayer confidentiality at risk. As a general rule, one-off activities are good candidates for outsourcing. ${ }^{29}$

\subsubsection{Federal countries}

In federal countries, some decentralization is inevitable if taxing powers are divided between higher and lower levels of government, leading to the fragmentation of the TA by assigned tax. It is important, in such a context, to have coordinating mechanisms and information-sharing arrangements among the TAs. While informal coordination channels usually develop, formally designated units that usually report to the head of the central TA are important.

\subsubsection{Cross-jurisdictional cooperation}

In countries with extensive external interactions, special headquarter units responsible for coordinating with other countries and international country groupings should be provided for. The scope of activities of such units will be discussed further.

\subsection{Political Economy Considerations in Tax Administration Reform}

The TA occupies an important place in the political economy of a country as its actions affect common citizens and businesses. Political control of the TA is the norm rather than the exception.

\subsubsection{The role of autonomous revenue authorities}

As a reaction to politicians' excessive interference in the working of the TA, there has been a movement to separate the policy aspects and the administration of taxes and create independent revenue authorities to deal purely with TA issues. But as Everest-

\footnotetext{
${ }^{28}$ For an overview and history, see Stella (1993) and Byrne (1998). See also Acuna and Fernando (1992). For an overview of the zamindari system in India, see McLane (1977). Tax farming in local governments in modern China is discussed in Zhu and Krug (2005).

${ }^{29}$ See Grout and Stevens (2003).
} 
Phillips (2008) states, the results have not always been good. Even while these bodies have been good at reforming the TA, the sustainability of these reforms is less clear. ${ }^{30}$ Some of the implications of the creation of autonomous revenue authorities are that they usually get to keep a percentage of the revenue they generate. While this ensures their independence, it has had unintended consequences such as:

- Higher salaries for tax officials, as compared with other civil servants, making them the envy of their colleagues and resulting in poor working relationships

- A "brain drain" from other ministries as the best talent is attracted by the TA's higher salaries

- Government backlash as TA actions to combat widespread tax evasion attract political attention

- As policy makers become administrators (drawn by the higher salaries), a lower level of policy making and one increasingly dominated by the TA perspective (which sees tax policy solely as a means of short-term revenue generation, with little consideration of the overall investment climate).

\subsubsection{Visible versus less visible tax collection (the role of tax withholding)}

The political sensitiveness of taxation implies that tax-collection mechanisms that are less visible are preferred to those that are more visible. This makes tax withholding a preferred collection mechanism as compared with direct tax payment by the taxpayers. Withholding improves compliance for various reasons as taxes are collected from some of those taxpayers who were unlikely to pay taxes themselves. There are also psychological reasons why risk-averse taxpayers are less likely to game the system when the taxes are already in the hands of the tax authorities. But tax withholding, by its very nature, shifts the collection burden onto the taxpayers, increasing their compliance costs (especially decreasing their cash flow). Ideally, withholding should be used only when the additional compliance that it may result in trumps the compliance cost. But there is a political reason why governments might prefer excessive withholding in order that tax may be collected less visibly through third parties.

\subsubsection{Tax administration and corruption}

Corruption is a significant issue in most TAs in developing countries. Hence system simplification, one of the goals of which is to reduce unnecessary interaction with tax authorities, creates less opportunity for corrupt officials to extract money from taxpayers. Any intervention to improve the tax climate is likely to be opposed from within the TA, and strong political support is a prerequisite to any tax-simplification program. In the case of India, as shown in box 5.3, it was found that the process of computerization suffered because tax officials wanted to continue interacting with

\footnotetext{
${ }^{30}$ Ibid footnote 3, page 18.
} 
taxpayers and refused to accept the front-office/back-office approach. As a result, only existing processes were computerized, which made the system worse.

In order to tackle this issue, tax-simplification interventions have to be accompanied by intensive administrative training, especially on issues of integrity and the development of a work ethos. In addition, the reform process needs to improve the working conditions of tax officials to increase the likelihood of their buy-in. Broader issues of governance are addressed in greater detail in chapter 7 .

\subsection{Taxpayer and Business Registration}

As pointed out above, a primary requirement for a TA is to have an up-to-date and comprehensive record of taxpayers in the form of a taxpayer master file. A master file should ideally have information on all potential taxpayers and be able to uniquely identify them. This, in turn, requires a system of unique taxpayer identification numbers (TINs) that can preferably lend themselves to incorporation in a computer database. In some countries, business and tax registration are separate and the business registrar seldom interacts or shares information with the tax authority. In other cases, in Sierra Leone for example, tax registration is a prerequisite for business registration. Until 2006, the tax authority of Sierra Leone collected advance tax when businesses came to them for the purpose of registering with the business registrar. In fact, this feature of the registration process dissuaded many businesses from registering in the first place and it was one of the reasons many firms operated in the informal sector. ${ }^{31}$ In Russia and Azerbaijan, on the other hand, tax registration is the primary form of registering a business. The main purpose is to use the better computer hardware and network across the country to maintain a unified registrar. But the purpose of business registration is quite different from that of tax registration, and it is unlikely that the tax authority can provide all the services that a business registrar traditionally provides, such as name look-up, issuance of trademarks, management of disputes, and so on.

\subsubsection{Taxpayer numbering}

Different countries have different approaches to taxpayer numbering. Significantly, even many developed countries have master files that are not comprehensive (OECD 2006). The assignment of TINs is also closely related to the registration of taxpayers, such as for the value-added tax (VAT). Several important aspects of the TIN will be discussed.

5.4.1.1 Unique versus "piggy-back" numbering. If a country has a comprehensive and reliable system of citizen numbers maintained by the government and

${ }^{31}$ See FIAS (2006). 
also comprehensive numbers for other entities, particularly businesses, then it is generally cost-effective for a TA to use these numbers instead of unique TINs (such as in the United States and Canada). Information available with such numbers, if not sufficient for the taxpayer master file, can be supplemented by the TA through an appropriate form.

5.4.1.2 Number design and linking. Taxpayers cannot be expected to remember their numbers if there are more than, say, 10 to 12 alphabetical or numeric characters. As will be discussed further, once a reliable numbering system for some or all citizens (and other entities) of a country is in place, a variety of piggy-back uses are likely to emerge. So designing easy-to-recall numbers is useful. Of the 12 digits, one is needed as a "check" digit to ensure that numbers incorrectly entered in a database can be automatically recognized. Other than this, numbers need to be unique for each taxpayer, requiring six or nine characters. ${ }^{32}$ Number capacity needs some slack so that the numbers need not be recycled too soon after an entity ceases to be a taxpayer. The remaining two to five digits can either be dropped (making TINs easier to remember) or can be coded so that TINs are informative about the stable characteristics of taxpayer type (for example, one digit coded to distinguish between residence plus individual versus various nonindividual entities), location of headquarters ( 0 for individuals since their location may not be a stable characteristic), taxes payable in the year of the TIN assignment, obligation to withhold taxes or not, and so on.

The main advantage of common numbering across taxes is that it eases the task of consolidating information and cooperation across TAs. The potential disadvantage is that numbers become either unwieldy or uninformative. For example, dedicated VAT or customs numbers can use their free digits to identify the registration status and class of taxpayer goods or services (for example, by using two or three digits of the harmonized system of nomenclature, or HSN), while income tax numbers could reflect the type of economic or business activity. If different numbers are used or if there are many taxpayers with tax obligations in foreign jurisdictions, taxpayer master files should include information on as many important taxpayer numbers as possible from different TAs to facilitate information exchange and coordination.

5.4.1.3 Comprehensive taxpayer numbers. As discussed, piggy-backing on comprehensive citizen and business numbering systems ensures that all potential taxpayers have assigned numbers. If these are not available, then there is a trade-off between instituting a procedure that casts a wide net and collects regular information about many potential taxpayers and a master file that is easier to maintain but has limited coverage. Less comprehensive number systems, say, restricted to persons with current tax-related obligations, increase the likelihood of "ghosts" or taxpayers not in the TA's master file, but decreases the likelihood of fruitless TA inquiries about potential taxpayers without current tax obligations (such as legitimate nonfilers and stop-filers). ${ }^{33}$

${ }^{32}$ Nine characters allows for one short of 1 billion unique numbers. 
Coordination and information exchange will also be more difficult under limited numbering systems if taxpayer bases for different taxes do not coincide.

5.4.1.4 International issues. Procedures to coordinate the TINs and the exchange of information should ideally be worked out formally with bilateral tax-treaty partner countries, particularly if the treaties involved contain information exchange and taxcollection-assistance articles, such as articles 25 and 27 of the OECD's Model Tax Convention.

\subsubsection{Prevention and detection of number-related noncompliance or fraud}

Several types of number-related fraud should be looked into to ensure that numbering is reliable:

- Taxpayers with no TIN. This can become a major problem in the case of informal and small businesses and also among nonresidents connected to residents via business transactions.

- Taxpayers with more than one TIN. This is particularly problematic among business entities that change their location or business description soon after being assigned numbers and then get new TINs.

- Use of incorrect TINs. To mitigate the problem of TIN misquoting or fraud, penalties should, of course, be a part of the tax laws enforced. Supplementary information or (for individuals) physical production of TIN cards with photo IDs is required in some countries. As is done in Canada, a useful strategy is to use the TINs for a government service beneficial to taxpayers, such as social security payments.

\subsubsection{Use of TINs for broader reporting purposes}

Some jurisdictions (for example, India) make it compulsory for TINs to be quoted in documents relating to high financial value and certain nonfinancial transactions; they have also imposed information-reporting requirements on certain third parties (usually large financial firms) to report large transactions to the TA. On the one hand, these practices supply the TA with a regular flow of information on transactions relevant to tax dues. On the other hand, they increase taxpayers' incentives to engage in number fraud. They also increase the compliance costs of affected third parties and, depending on the specific procedures, taxpayers. Hence, only limited use of this strategy appears to be worthwhile, although pilot introduction to assess noncompliance incentives and monitoring costs is recommended.

\footnotetext{
${ }^{33}$ In database-retrieval systems, performance parameters include "precision," or type-II error, and "recall," or type-I error. Precision (or rather imprecision) measures the percentage of false negatives or data not retrieved that should have been retrieved in a search, while recall measures the percentage of false positives.
} 


\subsubsection{Registering taxpayers}

Registration for taxes, such as the VAT, plays an important role in determining the taxable status of businesses and their compliance obligations. ${ }^{34}$ VATs in most countries can have up to three tax regimes: (i) exemption of very small businesses; (ii) a simplified regime for small businesses; and (iii) full VAT compliance and payment obligations (including entitlement to VAT credits and refunds) for registered businesses above a threshold. ${ }^{35}$ Clearly, where the TINs exist, the same numbers should be used for registered taxpayers, or registration numbers should be linked to the business TIN. It is important to note that registration is usually linked to the size of the current tax base of the business and is far from a stable characteristic. So, including direct indicators of registration status in the TIN is not a good practice. Since in most countries, taxpayers above and below a consumption-tax registration threshold face different tax regimes, the registration threshold has an important impact on taxpayer compliance, compliance costs, and also TA costs. Too low a threshold leads to too many taxpayers and an administrative burden out of line with potential extra revenues. A solution adopted in many jurisdictions is to allow voluntary registration of businesses below the registration threshold (with safeguards against misuse) and with full VAT treatment made available to registered businesses. Small exporters are typically among those who choose voluntary registration to take advantage of the zero rating of exports.

\subsection{Filing Tax Returns}

There are several important TA considerations regarding the filing of tax returns. Each should be addressed to improve the efficiency of tax collection.

\subsubsection{Official versus self-assessment}

Before discussing return filing, taxpayer obligations need to be planned. Here, the most important question is whether to mandate self-assessment or official assessment. Under official assessment, taxpayers report their taxable transactions to the TA, which then calculates their tax liability. Under self-assessment, taxpayers calculate their own tax dues. When returns need to be filed once a year and when tax laws are complex, official assessment shifts the burden of tax calculation to the TA from the taxpayer, resulting in reduced compliance costs but higher TA costs. Official assessment also does away with a raft of tax offenses associated with incorrect tax calculation. Third, however, if the TA has a low technical capacity or if corruption is an issue, incorrect assessments may negate the benefits of official assessment. For consumption taxes such as the VAT, where returns are usually filed quarterly or

\footnotetext{
${ }^{34}$ For a comprehensive discussion of threshold and registration issues, see Ebrill and others (2001), chapter 11.

35 An excellent overview of VAT issues can be found in Ebrill and others (2001).
} 
monthly, official assessment can end up increasing the cost of taxplayers' compliance (since they will have to make tax payments only after their assessments are made, requiring an additional interaction with the TA) while raising TA costs substantially (Ebrill and others 2001). For annual property taxes, self-assessment can lower compliance costs and reduce the scope for corruption if supported by adequate and transparent property-valuation procedures. Otherwise there is limited difference in this tax between official and self-assessment.

\subsubsection{Taxpayer services and complex tax returns}

Under self-assessment, taxpayer services, particularly information services, need to be much more effective than under official assessment. Perhaps more important, several return forms need to be provided. Information required should permit at least prima facie checking for accuracy from larger taxpayers and from those with complex tax affairs. (This issue is revisited later.) For small taxpayers and those with relatively uncomplicated tax affairs, returns should be simple and amount to little more than a single figure for the taxable base (for example, income) and a second figure for tax due and, if needed, interest or penalty for filing after the due date.

In terms of returns, the "gold standard" is prefilled returns sent electronically to taxpayers for their verification and concurrence. ${ }^{36}$ This requires the TA to have an effective system of cross-matching returns and the ability to automatically generate returns for taxpayers, with the master-file, taxable base, and tax due details filled in. Even if this standard is not possible to attain immediately, mailing of the return forms to the taxpayers and instituting secure systems for return filing and receipt increases taxpayer convenience greatly, besides reducing the TA's internal returns-processing costs. The many jurisdictions where taxpayers choose not to file returns by post for fear of loss in transit (or on receipt at the TA office) should consider this a major weakness.

\subsubsection{Records to maintain}

Regardless of whether a potential taxpayer is required to file returns or not, the taxpayer's recordkeeping obligations need to be considered. Large taxpayers can even be required to have their business books audited by commercial accountants, an issue discussed earlier in relation to outsourcing. While large and perhaps medium-sized taxpayers can be required to keep comprehensive records relating to their taxable dealings for a sufficient length of time (say, three years), other groups of taxpayers should have reduced recordkeeping requirements. Large and medium taxpayers liable for the VAT should, in particular, be required to keep all VAT invoices for a specified period. Small taxpayers, especially those who have all tax dues withheld, may be exempt from recordkeeping requirements, even if this leads to a small risk of taxes

\footnotetext{
${ }^{36}$ As is done in some Nordic countries. See OECD (2006), figure 7, and related discussion.
} 
escaping the TA net. Instead, withholders should be required to maintain appropriate records. In the case of the informal sector and illiterate taxpayers, for which recordkeeping will impose high compliance costs and possibly lead to large-scale noncompliance, alternative and presumptive tax regimes are worth considering.

\subsubsection{What to file with the return}

The compliance verification cost of the TA is lowered if taxpayers are required to file documents to prove their tax base claims (exempt and marital status, eligibility for deductions, tax payments made, taxes withheld, and so on). But this greatly increases the taxpayer's compliance costs. Furthermore, in the case of e-filing, filing the supporting documents becomes difficult if not impossible. Requiring documents to be filed will then either decrease the feasible extent of e-filing or discriminate against taxpayers who file paper returns. Hence, the number of supporting documents to be filed with returns should be minimized, though taxpayers should maintain documents so that they can show them to the TA if asked to do so (for example, if they are audited).

For large and medium taxpayers, an important trade-off arises in relation to the extent of detail called for in a tax return or, alternatively, the amount of documentation to be enclosed with the return (more implies higher compliance costs) and the extent to which third-party information can be matched with the returns (thus increasing the TA's ability to verify that all taxable amounts are reported). For example, do complete details need to be itemized regarding interest received from banks? Or, for VAT, should all invoices be sent with the returns? This decision has to be country specific after carefully weighing the costs and benefits. In particular, larger taxpayers with computerized data can be asked to file transactions or VAT invoice data using computerreadable media. The TA should not require more information from the taxpayers than they can realistically make use of. Additional records kept by the taxpayer can always be accessed in the case of an intensive audit, as discussed below.

The second issue is if taxpayers filing paper returns are permitted to enclose tax payments by check (or cash) with returns. This depends on the extent to which such payments can be processed and safeguarded in the TA office responsible for receiving returns, and many TAs rightly don't accept such payments. Clearly, allowing check or cash enclosure is for taxpayer convenience.

\subsubsection{Who should file}

Generally, other than taxpayers who have all their taxes withheld, all taxpayers with tax dues or refund claims are required to file tax returns. For individual income tax, if tax is withheld from salary payments to residents and if, in addition, withholders are authorized to deduct taxes related to certain types of other income (for example, interest income), then this is one group that can be exempt from direct return-filing requirements. But withholders should be required to provide details of the salary 
paid and other income reported for each taxpayer whose taxes are withheld. Other groups that may be exempted from filing requirements are pensioners or those with only income from assets. The corresponding situation under official assessment is where employers and other payers must submit comprehensive information on payments made to the TA for each employee or interest earner. For the VAT, small taxpayers, if anyone, should have simplified returns to file.

For small and individual taxpayers, permission to use tax representatives or preparers to file returns lowers the taxpayer's compliance costs while reducing the risk of faulty and incomplete returns. In some countries (as in Canada) tax preparers are even required to maintain copies of documents for e-returns in case of a subsequent tax audit. In countries where there is an adequate number of accounting professionals, allowing the use of tax preparers licensed by the TA (or other appropriate authority) may greatly increase taxpayer convenience, particularly for small businesses and self-employed professionals.

\subsubsection{Filing requirements not directly related to taxes due}

In some countries (for example, India) where there is limited direct information on the income, sales, or asset holdings of nonfilers, return filing is mandatory if the potential taxpayer has certain visible signs of wealth or indulges in lavish expenditure. ${ }^{37}$ This anti-evasion measure needs to be backed by adequate laws that require the quoting of taxpayer numbers for certain transactions, third-party information reporting, and internal TA systems that can cross-match third-party information with a taxpayer's records. Without adequate systems, such requirements may or may not increase compliance, but they definitely increase the TA's return-processing workload.

\subsubsection{Stop-filer control}

Once filing requirements are determined, procedures are needed to determine the treatment of stop-filers or those who do not file tax returns even if required to do so. For effective stop-filer control, adequate penalty regimes and imposition procedures need to be in place, a reliable taxpayer master file needs to be created, and procedures instituted to verify that the taxpayers on the master file who are required to file returns have indeed done so.

An important issue to be noted while implementing stop-filer control is in relation to the filing requirements for those with fluctuating incomes near a tax threshold. Short of universal filing, with its attendant high compliance and administrative

\footnotetext{
${ }^{37}$ In India the "one-in-six" scheme required individuals with one of six observable possessions or transactions to file returns. The scheme was discontinued in 2007. In addition, five-star hotels and some others were required to file information returns on lavish expenditure exceeding individual thresholds. This requirement is still in existence but its effectiveness is hampered by inadequate taxpayer numbering and cross-matching systems.
} 
burden, the next logical filing threshold for taxes such as the income tax or VAT (aside from the special categories required to be filed as an anti-evasion measure) is the tax threshold. But without safeguards, a situation can arise in which a taxpayer is required to file returns in one year and not the next. This hampers effective stopfiler control. To circumvent this, taxpayers who have taxes due, losses to report, or refunds due in one year should be required to file returns for one additional year even if no taxes or refunds are due and there are no losses to carry forward.

\subsubsection{Periodicity}

For income and property taxes, annual returns are typically considered adequate, although advance-tax payments on estimated income or property tax dues may be required more often (typically quarterly) for large and medium taxpayers. This is to ensure a steady flow of revenue to the treasury. For temporary residents or nonresidents, tax payments before they leave the country should ideally also be provided. For consumption taxes, returns and tax payments are typically required fortnightly or monthly (or quarterly for small taxpayers). If refund processing is done monthly, it is also a convenience for the VAT taxpayers to whom refunds are due.

\subsubsection{Decentralized versus centralized returns filing}

In jurisdictions where paper returns are filed, there are both advantages and disadvantages associated with the centralized filing of tax returns. Centralized filing and recording of filed returns facilitates the functional organization of the TA where a separate returns receipt and processing division can be instituted. Centralized filing also allows the TA to take advantage of economies of scale in the processing and recording of received returns. Mechanical processing of received returns using standardized (paper) return forms and devices such as mechanical envelope openers and bundling of returns using conveyer belts and related equipment becomes economically viable. ${ }^{38}$ Also possible is subsequent data recording of returned information to create an online database. In turn, this makes it difficult for returns to be subsequently tampered with and altered in the case of collusion between the taxpayers and TA officials. If the data capture all returned information, especially for simplified return forms, then there will be no further use for the paper returns filed except as evidence in court proceedings. So centralized warehouse storage of paper returns in bulk also becomes possible. A key requirement, not met in all countries, is a reliable system of return filing using the postal service or an acceptable substitute that is convenient to the taxpayer. Disadvantages of centralized processing include the subsequent secure communication of returned information to units responsible for further processing of the problem returns and the issue of where to store the updated taxpayer's records.

\footnotetext{
38 The "T-1 assessing pipeline" used to process paper returns by Revenue Canada (Revenue Canada 1993) is a good example of a mechanical, IT-linked, returns-processing system.
} 
Security problems also include maintaining confidentiality of taxpayer records in large databases and possible database erasure. Communication problems are made worse if paper returns need to be subsequently used. For VAT returns, centralized filing of monthly paper returns only magnifies these problems. Delayed refunds processing is another important risk area.

A problem with decentralized filing arises if a taxpayer characteristic that lacks stability is used to assign taxpayers to different filing jurisdictions, especially if taxpayer records are decentralized and kept in paper databases. Transfer of a taxpayer from one jurisdiction to another can then result in a loss of control over stop-filers and noncompliant taxpayers. Differences in the effectiveness of tax-return offices may provide additional loopholes to tax evaders. ${ }^{39}$

Decentralized receipt is possibly the only feasible option with paper returns and manual processing. In addition, it might be the only system that is not unduly inconvenient for taxpayers if returns are filed in person. The main advantages of decentralized filing are faster identification of stop-filers and fewer communication problems. To avoid file tampering or subsequent collusion, one option is to require returns to be filed at central locations covering a number of local tax offices. This balances taxpayer convenience with the need to protect revenue and puts obstacles in the way of abuse of return receipts. The need for prompt identification of stop-filers and also the prompt processing of refunds, increases the attractiveness of decentralized receipt and processing of VAT returns.

\subsubsection{Electronic filing}

Two current e-filing systems are direct online filing of returns by taxpayers (via the TA's internet portal) and e-filing by tax preparers. Both can greatly reduce taxpayer compliance costs as well as TA costs. While none of the problems of decentralized filing need be associated with e-filing, it has its own potential drawbacks. Direct return filing by taxpayers requires them to be IT literate, an infrequent occurrence in many developing countries. Tax preparers must also be IT literate. Meanwhile, the data in electronically transmitted returns are vulnerable to attack, as are other TA IT systems connected to the e-filing portal. Another inherent problem to be tackled is the financing of capital expenditure and also the acquisition of compatible software by tax preparers-along with the need for tax preparer vetting and registration. Tax preparer penalties and monitoring also need to be developed. Appropriate changes need to be made in the TA law to make e-filing legal; experience in the precise nature of these legal changes can now be readily tapped from developed countries.

\footnotetext{
39 Das-Gupta, Ghosh, and Mookherjee (2004) study Indian income-tax evaders in the 1990s, given a single-officer TA organization design and assignment or reassignment of taxpayers to "wards" and "circles" based on the level of their reported income.
} 


\subsubsection{Withholder and third-party returns}

Periodic filing of withholding and third-party information returns need to be instituted to augment a TA's information base to detect noncompliance. Besides withholders, important examples of third parties include banks, brokerage houses, and financial companies; government agencies such as property registration authorities, other TAs, border-control agencies, and business-licensing authorities; and purveyors of real assets (including houses and cars). The filing of such information requires the development of appropriate returns and institution of adequate procedures. In particular, filing of returns by large withholders and institutions on electronic media is to be advocated. The effective use of this information depends on the existence of adequate cross-matching infrastructure and procedures in the TA, a requirement that is linked closely to the degree of TA automation. ${ }^{40}$

\subsection{Payment of Taxes ${ }^{41}$}

\subsubsection{Modes of payment}

The two major ways taxpayers can pay taxes and other dues to the treasury are directly and through tax withholding. For personal income tax, OECD (2006) classifies returnfiling-cum-tax-payment systems into four groups: ${ }^{42}$ (i) cumulative withholding (tax return-free for most employee taxpayers); (ii) noncumulative payment (returns required from most employees); (iii) noncumulative withholding (prepopulated returns sent to taxpayers for validation); (iv) no withholding (annual returns required).

The first three systems rely extensively on employers to withhold taxes, thus reducing taxpayers' direct compliance burden while ensuring a steady revenue stream to the treasury. The fourth system is perhaps the only one possible for independent taxpayers with business, professional, or rental income. For consumption and property taxes, withholding offers limited possibilities. In many jurisdictions "advance-tax" payments from large taxpayers not subject to withholding are required monthly or quarterly even though taxes are assessed annually. Since such current payment systems require taxpayers to pay a part of their taxes during the year on their estimated income (or estimated sales or value added if the tax is a sales tax or a VAT), the TA needs to prescribe rules for estimating income. ${ }^{43}$

A problem with current payment systems arises when taxpayers, such as business or professional taxpayers, face great income uncertainty. There is a trade-off between

\footnotetext{
${ }^{40}$ OECD (2006), tables 12 and 13, contain information on third-party information reporting and withholder reporting requirements in member (and some nonmember) countries.

41 This section draws, in part, from Bagchi, Bird, and Das-Gupta (1995).

42 See OECD (2006), box 14 and table 10.

${ }^{43}$ Apart from smoothing the flow of revenue, the current payment system leads, more or less, to horizontal equity in the treatment of the taxpayers subject to withholding and those whose taxes are not withheld (for example, the self-employed).
} 
ensuring a steady stream of revenue to the treasury and not imposing an inequitable burden on taxpayers through rules that may end up imposing excessive advancepayment obligations on them. Practices vary among countries with current payment systems, none of them entirely satisfactory. It is probably best to work out countryspecific rules after soliciting taxpayer input and feedback on proposed rules.

\subsubsection{Direct payment of dues by taxpayers}

Where direct tax payments are required, taxpayer convenience, subject to protection of revenue interests, is of major importance. OECD (2006) lists seven direct payment channels in member and selected nonmember countries. These are (i) phone banking, (ii) direct online payment, (iii) a direct debit arrangement with the taxpayer's bank, (iv) a payment kiosk, (v) mailed check, (vi) in person at the TA or designated agent, and (vii) in person at a bank. ${ }^{44}$ Of these methods, the most prevalent in surveyed member countries are (i) to (iii), while in the nonmember developing countries surveyed, (vi) and (vii) predominate.

If payments in person are still the norm, several convenient tax payment locations are to be preferred, subject to cost-effectiveness considerations. One important requirement is the ready availability of forms needed to accompany payment at the payment locations.

A second issue is how taxpayers should pay, especially those with cash-flow difficulties. For taxpayers who are not considered at risk of leaving the jurisdiction with unpaid tax dues, payments in installments are allowed in several countries after TA clearance is obtained. For installments, the interest rate charged should be high enough with reference to prevailing market rates of interest so that such "loans" from the treasury are not viewed as a cheap source of finance. In fairness, delayed payment of refunds by the government should also bear interest at the market rate.

The third important issue is the recording of taxpayer liabilities. Taxpayer current accounts are widely advocated ${ }^{45}$ but seldom used in most countries. In a current account, all payments and dues of the taxpayer are recorded. The advantage to the taxpayer is that only net dues to the fiscal authority need to be paid, while the net refund of taxes owed can also be automatically paid to the taxpayer. An important consideration for a current account and other payments systems is in relation to unverified tax dues, particularly in connection with self-assessed refunds. Where the verification process is likely to be protracted, refunds should clearly be paid out despite the risk to revenue. The other major issue is in relation to disputed claims: should the taxpayer have to pay what the TA demands even if the payment demanded has been appealed by the taxpayer? Country practices may vary; some require payment of disputed dues (unless the appeal adjudicator allows the taxpayer to delay the payment

\footnotetext{
${ }^{44}$ OECD (2006), table 33.

${ }^{45}$ See, for example, Vazquez-Caro, Reid, and Bird (1992); and Silvani and Baer (1997).
} 
until the dispute is resolved) while others do not. Neither system is completely satisfactory since both leave open the possibility of abuse. Requiring payment can lead the TA to make exaggerated tax demands; not requiring payment can lead to frivolous tax appeals.

With many taxpayers, a computerized current account database is possibly the only realistic option. The fourth issue, recovery of delinquent taxes, is discussed later in the chapter.

\subsubsection{Withholding taxes ${ }^{46}$}

Tax withholding is an important tax-collection channel that reduces the tax compliance burden on small taxpayers (by shifting the burden to agents, who have lower compliance costs due to economies of scale), reduces the TA's administrative costs, and safeguards revenue interests. The other advantage is that withholders can be required to pay taxes to the treasury more frequently than individuals, given their limited compliance costs. ${ }^{47}$ Withholding was first used in Britain in 1803 and is now used in most tax systems, especially with respect to income tax. ${ }^{48}$ Under withholding, taxes are paid to the treasury by those making potentially taxable payments with only the net of tax payments being made to payees. The feasibility of extensive withholding depends on the size of the organized economy and the prevalence of proper accounting practices. But the TA pushes its responsibility and the cost of collecting taxes to certain businesses.

While the advantage of a withholding regime for the TA is that it enhances the government's cash flow from tax revenues, for businesses, withholding causes cashflow problems, particularly when the withholding rates are much higher than what the businesses' final tax obligations to the government will be. The withholding regime also carries a compliance cost for businesses that have to collect taxes on behalf of the government and hand them over to the government with supporting documentation.

While withholding has its advantages, it has to be managed; this places an additional administrative burden for the TA. In some countries (Burkina Faso, Sierra Leone, and Nigeria are examples), tenants are by law obligated to withhold taxes from their landlord and turn it over to the TA. Apart from creating considerable friction between landlords and tenants, it also results in a large number of withholding agents that the TA now has to manage.

\footnotetext{
46 The discussion of withholding draws extensively on Bagchi, Bird, and Das-Gupta (1995).

${ }^{47}$ For a summary of OECD country practices, see OECD (2006), table 13.

${ }^{48}$ Exceptions are France, Switzerland (for salaries), Hong Kong, and Singapore. Information, except for Hong Kong, is in OECD (2006), table 11. For Hong Kong, see Soos (1990).
} 
FIGURE 5.2 Efficient withholding of taxes

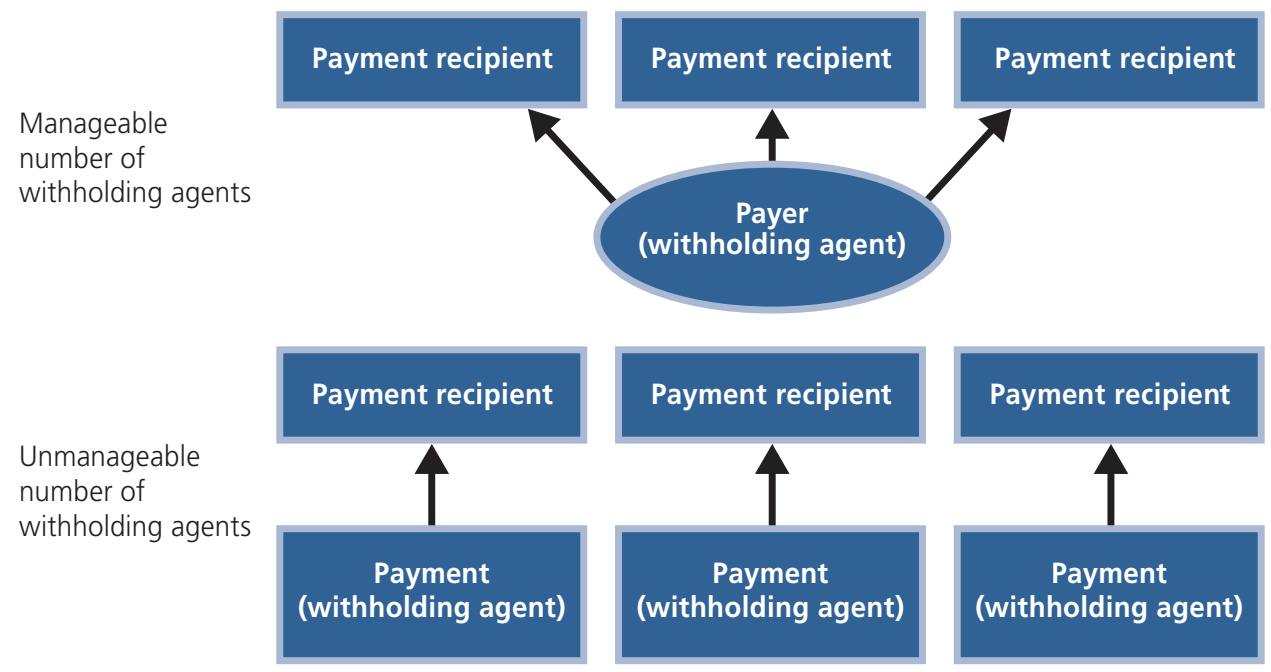

\subsubsection{Conditions for efficient withholding}

The basic rationale for withholding is that it is simpler to collect taxes from a small number of corporations or government agencies than several individuals. While this is not necessarily unfair, it is important that the following conditions be present for any such regime to be effective:

- Income is likely to be generated in the hands of the recipients as a result of payments made by the withholding agents.

- The payments are likely to be made to the taxpayers who are less likely to comply with their tax liabilities.

- The withholding agents are those that the TA can easily manage and monitor.

- The cost of managing the withholding agents for the TA is considerably lower than ensuring the same level of compliance from the recipients of the payments.

- Withholding does not create excessive pressure on the TA to process refunds of those whose taxes are withheld.

- The cost for withholding agents to comply with their withholding tax liability is not too high compared to the cost of complying with their own tax liability.

For the persons whose tax is withheld, it is crucial that:

- The tax withheld be close to their expected tax liability

- The withholding considerably reduce the cost of compliance

- As far as possible, the withheld tax be the final tax payment 
- Withholding does not create excessive cash-flow problems for taxpayers

- Withholding does not create opportunities for tax planning, such as changing the organizational form.

If any of these conditions are not satisfied, the efficiency of the withholding system is considerably reduced, resulting in a higher burden for withholders and for those whose taxes are withheld.

A small compensation to the withholding agents for the cost of compliance is the opportunity to use the tax collected on behalf of government to shore up their own cash flows. In extreme cases this could even be misused and not handed over to the government, thereby creating another point of enforcement for tax authorities.

Another set of problems occurs when withholding agents close their business without handing over the taxes owed to the government and leave taxpayers in the lurch. It is unclear if the responsibility for uncollected taxes rests with the government (whose responsibility it is to enforce the withholding tax responsibilities of the agents in the first place) or with the final taxpayers whose tax did not reach the government. It is not uncommon for the status quo in many countries to be the latter.

Important withholders of taxes in most countries include employers, banks and others liable to pay interest, and government departments (from contractual payments). Withheld taxes from wages are sometimes treated as a separate levy, the pay-as-you-earn (PAYE) tax. As a convenience to nonresidents and also to safeguard revenue, withholding is also commonly used for taxes on incomes paid to nonresidents from salaries, royalties, technical-service fees, and interest and dividends. For many nonresidents, taxes are withheld rather than made a part of taxpayers' total annual tax payment. ${ }^{49}$ Under consumption taxes, sellers are actually tax withholders since these taxes are meant to tax consumption, not sales. When taxes are withheld by the payee, not the payer, this is sometimes referred to as reverse withholding. Under the VAT, purchasers can, in principle, credit such withholding against taxes due from them. Purchase taxes are levied when the buyer (typically a large entity) is required to withhold taxes from the seller (typically from the informal or agricultural sector) to prevent taxes escaping the tax net.

The introduction of withholding can result in a substantial revenue gain. ${ }^{50}$ Withholding, particularly final withholding, decreases the number of tax-paying entities that a TA must deal with directly. Even if the number of taxpayers increases (if withholders

\footnotetext{
${ }^{49}$ Final withholding taxes for different income sources makes the income tax schedular rather than global. Alm and Wallace (2006), analyzing the Jamaican experience, make the case that such taxes are better suited administratively to developing countries where noncompliance is a serious problem.

${ }^{50}$ See Vazquez-Caro, Reid, and Bird (1992) for Colombia; Soos (1990) for Malawi and Australia; and Wallschutzsky (1991) also for Australia.
} 
and those whose taxes are withheld are required to file tax returns), the percentage of taxes collected from large taxpayers or tax agents increases, thus safeguarding revenue. Another advantage is that withholding may also help to identify potential taxpayers not currently in the master file. ${ }^{51}$ A drawback of withholding taxes is that, unless they are final, excess taxes may be withheld, resulting in large refunds, (causing hardship for those to whom refunds are due) and at the same time increasing the workload of the TA. Affected groups typically include retirees whose major income sources are interest and dividends. ${ }^{52}$

Since withholding requirements do result in some compliance costs, particularly for small withholders, they should be allowed to claim the cost of processing, remitting, and reporting withheld taxes as a business deduction. An automatic method of compensation is to allow withholders to keep and use withheld taxes for a period of time before they need to remit the taxes to the treasury. This causes withholding costs to be compensated at a rate that will vary with the market interest rate (Acuna and Fernando 1992). To be equitable, the period of such "floats" should be larger for small withholders (for example, three months) than large withholders (such as monthly or even weekly).

Contrary to common belief, TA procedures for monitoring and enforcing compliance with statutory obligations by withholding agents are as vital as those for withholding fraud; while not as widespread as noncompliance, nonwithheld taxes are not uncommon. Furthermore, withholding tax fraud can lead to large revenue losses. Besides evasion by withholding agents, if the withholding agent and the taxpayer engage in collusion, then such taxes can, in principle, be no better than collecting directly from taxpayers. ${ }^{53}$

\section{Further Guidance}

- Jit B.S. Gill. 2000. "A Diagnostic Framework for Revenue Administration." The World Bank, Washington, DC.

\footnotetext{
${ }^{51}$ This was found to be one of the major benefits of a withholding system for contractors introduced in Australia in 1983 (Soos 1990).

52 One solution to this problem may be to allow private discounting of refund claims at the discounter's risk. See Bagchi, Bird, and Das-Gupta (1994). To facilitate this, the TA would have to introduce a procedure to accept refund claims from third parties.

53 See Yaniv (1988) and Baldry (1993) for a theoretical analysis of withholding-tax fraud. Evidence of lesser tax evasion by those subject to withholding is in Crane and Nourzad (1992). Soos (1990) points out irregularities in the reporting of withholding taxes in 24,000 of the 69,000 audited employers in the United Kingdom. Furthermore, he reports withholding tax evasion as among the most serious noncompliance problems in Canada and the United States. Other countries facing withholder evasion include Fiji, India, Kenya, Malawi, Malaysia, Malta, Sierra Leone, Sri Lanka, Swaziland, and Zimbabwe. In Sierra Leone, delinquent withholders are reported to include public bodies.
} 


\section{APPENDIX 5A}

\section{A Brief Introduction to TA Performance Indicators}

Many TAs use performance indicators of differing degrees of complexity; there is still no consensus on best practices in the design of these indicators. Furthermore, it should be noted that the comprehensiveness and the level of detail of performance indicators need to be traded off against their cost, which can quickly mount as the set of indicators becomes more detailed. Apart from cost considerations, at least 10 design challenges need to be highlighted:

- It should be noted that the absolute values of cardinal or ordinal performance measures are generally less useful and open to greater criticism than performance relative to a benchmark based on cross-sectional averages or past performance.

- For units that perform unique functions, including centralized functions such as payroll accounting, only benchmarks based on past performance will typically be available.

- Incomplete sets of performance indicators typically result in diversion of work effort to areas where performance is monitored and linked to rewards.

- While back-office functions seldom have measurable effects on the ultimate TA performance variables, such as revenue collection or detection of tax evasion, their support role is often crucial. Good performance pay or reward systems will ensure that back-office functions are not left out.

- "Success rates" typically distort performance incentives and so do not make good performance indicators. For example, if the rate of detected tax evasion is used as an indicator, this will cause the TA officials to focus detection effort on cases where the potential for detected evasion is high and not on cases with the greatest deterrence potential.

- Performance indicators often come as interlocking systems. For example, if the private sector practice of using "bottom-up" targeting for the TA staff effort is adopted, self-set targets and achievement of targets set need to be used in tandem to assess performance. 
- In different settings, units in which improvement, relative to benchmarks, ought to be measured will vary (as in absolute versus percentage improvement).

- Since performance is typically multidimensional, preannounced, and transparent, weighting schemes for different aspects of performance are needed. In particular, qualitative and quantitative measures of effectiveness and cost-efficiency should be included. For taxpayer-related functions, effectiveness should partly be measured by taxpayer feedback regarding compliance costs and time. This is particularly important where TA actions can result in revenue benefits but disregard taxpayer rights (as discussed in chapter 5).

- The variability in monetary compensation and qualitative job rewards introduced by performance-related components can have a negative impact on morale if the performance-linked component can result in a significant loss of earnings, particularly if performance is not entirely within the control of the individual or unit being evaluated. So the "risk-free" base pay component of compensation must be set with regard to compensation in similar, non-TA jobs.

Performance in certain areas, such as in establishing and sanctioning tax noncompliance, often spans more than one tax year and several functional activities. Rewarding good performance only on the completion of a tax proceeding may result in TA officials having to wait for an inordinately long time for their efforts to be recognized. This suggests the need for partial rewards for performance that can be paid out earlier, even if a case is still being processed. 



\section{Chapter 6: Tax Administration Simplification (Ensuring Compliance and Accountability)}

\section{CHECKLIST OF GOOD PRACTICES}

$\checkmark$ The tax simplification strategy does not undermine the ability of the tax administration (TA) to enforce compliance

$\checkmark$ The TA uses a risk-based audit strategy to improve audit efficiency

$\checkmark$ The TA collects information from different sources when assessing the risk of taxpayer evasion

$\checkmark$ The TA uses different kinds of audits to ensure compliance

$\checkmark$ The TA uses due process in the conduct of audits and treats taxpayers with respect

$\checkmark$ Taxpayers are provided with an accessible channel through which to voice their grievances

$\checkmark$ Tax appeals should not have preconditions such as prepayment of taxes

$\checkmark$ The TA has a strategy to deal with closing tax accounts

According to surveys conducted by the Organisation for Economic Co-operation and Development (OECD 2006), tax administrators have fairly uniform and more or less unrestricted power to require information from taxpayers and third parties, including other (nonstrategic) government departments. ${ }^{1}$ These powers include requiring third parties to file information returns. On the other hand, not all tax administrations (TAs) are allowed to search business premises and, particularly, places of residence: search warrants are needed for searching business premises in close to half the surveyed countries, and for residential premises in two-thirds. Warrants are also needed in about half the surveyed countries to seize documents from taxpayers. Many TAs also have broad powers to issue summons and interrogate taxpayers or related third parties in relation to tax cases.

\footnotetext{
1 See OECD (2006), table 18.
} 
In deciding the extent of information-collecting power, a key consideration is taxpayer privacy. Clearly, individual taxpayers' rights are of greater importance than that of other taxable entities. ${ }^{2}$ Potential harassment of taxpayers is also of concern. ${ }^{3}$ Consequently, checks on a TA's information-collection powers are crucial. Besides the use of judicial warrants, external reviews of the exercise of information powers are important. These possibly include reviews by supreme audit institutions in the course of performance audits of the TA, reviews by committees of representatives from the legislature, and, in cases where it appears indicated, reviews by anticorruption bodies. The TA should also be required to follow prescribed procedures when exercising its powers.

Some tax administrations tend to believe that more information and more forms and signatures improve compliance. But this is not always the case; some requirements only increase the cost of compliance for taxpayers. The goal is to balance the amount of information that taxpayers have to provide on themselves and others with the additional revenue that such information would help the tax administration collect.

\subsection{Sources of Compliance Information}

There are several sources of compliance information, ranging from taxpayer-reported details to information supplied by third parties outside the taxpayer's home country.

\subsubsection{Information directly collected from taxpayers}

The major source of information obtained directly from taxpayers is the information supplied in tax returns and, if noncompliance is suspected, information from financial records and interrogations during tax audits and investigations. Other sources include specific information required to obtain taxpayer relief and deductions or various clearances from the TA. Such information is usually summarized in the taxpayer's master file record and filed annual tax returns.

\subsubsection{Tax withholding and information reporting}

Information obtained from third parties is of paramount importance in determining the TA's ability to detect noncompliance or verify compliance. A useful strategy is for

\footnotetext{
2 An extended discussion is in Bagchi, Bird, and Das-Gupta (1994).

3 Midnight raids by overzealous U.S. Internal Revenue Service (IRS) officers, reported in the New York Times in 1998, are a dramatic example of this. See, for example the article "I.R.S. Hearings Resume" in the New York Times and another by Johnston (1998) there. See also the transcript of the Public Broadcasting Corporation TV show Washington Week in Review, April 16, 1999. For the United Kingdom, powers of the Inland Revenue were reviewed by 1982.
} 
TAs to require annual information returns from institutional third parties. As mentioned, most TAs have extensive powers to tap such information. But systems that use third-party information, except information from withholders, are very limited. Typically, use of such information requires IT capability, a reliable system of taxpayer numbers (which third parties must ascertain when transacting with taxpayers), and the filing of third-party information returns on computer media.

\subsubsection{The problem of preserving bank secrecy}

Since confidentiality of bank accounts and dealings is a key part of their services, tax authority information demands often conflict with the need for bank secrecy. Different countries have different restrictions on the extent to which TAs can demand information from banks. In the wake of increasing globalization, the OECD has set up a task force that has drafted a model list of tax authority powers and procedures for access to bank information on taxpayers. As of 2003, several member countries had agreed to limit bank secrecy and mandate tax authority access to bank information-particularly in relation to banning anonymous bank accounts, ensuring uniform minimum procedures for the identification of beneficial owners of bank accounts, and relating to cooperation in criminal investigations and tax fraud investigations. ${ }^{4}$ An additional requirement that facilitates international cooperation by several member countries is the modification of their laws so that TAs in these countries have the power to collect information from banks even if they do not apprehend any risk to their own revenues. This enables them to collect information to avoid double taxation by treaty-partner countries-if the treaties have a provision similar to the OECD Model Treaty (2005), Article 26, dealing with information cooperation.

\subsubsection{Other third-party information}

Three other TA information sources are of special interest. For tax fraud cases, many TAs pay rewards to informants for information leading to uncovering tax fraud. This is, unfortunately, a source of information with almost no substitute. A new-yet largely untapped-source of information of immense potential is via organized searches of the World Wide Web. The third source of information, in this case extensively used in around 40 countries, is private preshipment inspection to ensure correct customs reporting and valuation. As Yang (2005) discusses, the effectiveness of preshipment inspection depends on the proper design of the contract with preshipment firms and the capacity of the customs authorities to make use of the information they provide. When both conditions are met, preshipment inspection has proved to be effective in safeguarding customs revenue and preventing misclassification or underinvoicing.

\footnotetext{
4 Relevant documents are OECD (2000) and (2003).
} 


\subsubsection{Cross-jurisdictional cooperation}

If countries have extensive international economic ties, then taxation of nonresidents and residents with foreign interests gains importance. It is important, therefore, for countries to have a network of bilateral avoidance of double taxation treaties with major international partner countries. In particular, these treaties should contain a provision similar to the OECD Model Tax Treaty, Article 26, dealing with the exchange of information. ${ }^{5}$ Furthermore, TAs need to have specialized international tax divisions entrusted with cooperation with TAs in treaty-partner countries, particularly with respect to international information exchange. As has been discussed earlier, the most important prerequisite for effective information exchange is the ability to match taxpayer identification numbers (TINs) in home and foreign jurisdictions, a procedure that needs to be urgently attended to. Some developing countries with longstanding tax treaties negotiated prior to the expansion of the OECD Model Treaty to cover information exchange would be well advised to renegotiate these tax treaties to extend to information cooperation and also to assistance with tax collection (OECD Model Treaty, Article 27).

\subsubsection{Compliance costs}

One type of information that is important to assess the social burden of TA versus the benefits accruing from the revenue gathered is related to the cost of compliance of taxpayers and third parties. Such information can only be collected through extra effort on the part of the TA and will usually require additional surveys and specially designed questionnaires. While it is necessary for a socially responsive and efficient tax authority to collect such information periodically-especially with respect to newly introduced tax provisions and procedures-routine collection of such information may not be feasible for TAs in most developing countries. ${ }^{6}$

\subsection{Audit Procedures}

Tax audits are possibly the most important TA activity, with well-designed audit programs potentially having high direct and indirect compliance effects in relation to their administrative costs. However, tax audits can also impose high compliance costs on audited taxpayers, particularly if taxpayer convenience is not explicitly monitored. $^{7}$ Furthermore, given design and implementation problems, auditing is often among the least effective activities in TAs, particularly in developing countries. ${ }^{8}$

\footnotetext{
5 See OECD (2005).

6 A useful survey of compliance cost studies is Evans (2003). For developing country estimates see Shekidele (1999) and Chattopadhyay and Das-Gupta (2002, 2002a). See also World Bank and PriceWaterhouseCoopers $(2007,2008)$

7 For evidence from India, see Chattopadhyay and Das-Gupta (2002 and 2002a).

8 See the evidence in Ebrill and others (2001) for VAT audits.
} 


\subsubsection{Components of a good audit system}

Effective audit systems need to address at least eight key design and implementation issues:?

- Organization and staff strength

- Audit coverage in relation to available tax authority resources

- Internal versus outsourced activities

- Procedure for selection of audit cases

- The types of audit to conduct in different cases

- Audit procedures and associated training

- Management control, monitoring, and review

- Follow-up procedures for the imposition of sanctions and collection of additional dues

\subsubsection{Types of audit}

There are different types of verifications and checks that a tax authority can perform, which differ in their intent and thoroughness. ${ }^{10}$

6.2.2.1 Prima facie desk verifications. These are used when returns are checked for internal arithmetic consistency, eligibility for deductions claimed, credibility by using norms determined from data mining of past return and audit data, and information provided by the taxpayer across different taxes (for example, VAT, income tax, and possibly customs duties). The scope of these verifications will depend on the number of cases typically assigned to an audit officer and the extent of IT support to conduct these checks. In fact, it is possible for prima facie verifications to be automated, with only returns that fail to pass automated checks being flagged for further attention by audit officers. This is, in fact, the practice in several developed countries. For errors that are clearly apparent from the records (for example, arithmetic errors, application of incorrect rates of tax or deduction, returns that are incomplete in a material way), such verifications should lead to communication by the tax authority to the taxpayer to make good the error, or make good any shortfall in taxes paid. ${ }^{11}$ Ideally, a refund of mistakenly overpaid taxes should also be made. Notices and

\footnotetext{
9 This draws partly on Ebrill and others (2001).

${ }^{10}$ The discussion of audit types draws partly on Ebrill and others (2001; box 14.1, page 149).

${ }^{11}$ From the point of view of taxpayer convenience, a phone call to the taxpayer is perhaps the easiest and friendliest method of communication in the first instance, with formal notices being reserved if the taxpayer does not take necessary action or cannot be reached. To reduce potential corruption arising when the taxpayer is directly contacted, such phone calls should be made, if possible, by randomly assigned clerical staff as happens in commercial call centers. Records should be kept of such contacts to identify the tax authority staff member who made the call and to facilitate follow-up action if needed. For large taxpayers assigned to large taxpayer units, if any, special procedures can be applied.
} 
refunds should both indicate clearly that making good the assessment does not preclude further action (for example, an in-depth audit) by the TA.

6.2.2.2 Education and inspection visits. These inspections are manpowerintensive and are useful mainly for new taxpayers. They consist of visits to a potential business or professional taxpayer's premises to verify the taxpayer's awareness and understanding of tax obligations and also to verify that the taxpayer's books, financial documents, and business forms (for example, invoices and receipts) satisfy legal requirements. Such visits should typically be made by prior appointment. While noncompliance should be noted by the tax authority officer for possible future use, these visits are conducted primarily as a service to taxpayers and not a means to detect noncompliance-unless flagrant abuses are found.

6.2.2.3 Issue-oriented audits. These are typically desk audits in the tax office, where specific problems identified through prima facie checks are the focus. For consumption taxes, these audits can cover a number of within-year tax returns if needed. Issue-oriented audits should typically result in a final assessment of the tax due from the taxpayer for the tax period, barring evidence of large scale unpaid tax dues or fraud coming to light. A special case of such audits, not necessarily linked to prima facie checks, is the refund audit, particularly in the case of new businesses claiming specific deductions or in the case of the value-added tax (VAT).

6.2.2.4 Comprehensive desk audits. These audits may cover several taxes and tax periods. High-risk taxpayers (or their tax representatives) are asked to produce a wide array of books and records at the tax office and to provide oral or written answers to the queries of the audit officer or team. Though these audits are practiced in a number of countries, they are relatively ineffective at detecting major tax noncompliance, while imposing high compliance costs on the taxpayer.

6.2.2.5 Comprehensive field audits. These are typically conducted at the taxpayer's business premises and, with suitable safeguards against abuse by the TA, residential premises. These audits may cover several taxes and tax periods. Besides cases deemed to be high-risk from prima facie checks or issue-based audits, such cases are typically based on careful risk assessment and audit selection. A type of comprehensive audit practiced in some countries (for example, the United States) is the audit purely to facilitate risk profiling of taxpayers. ${ }^{12}$ For such audits, taxpayers are selected on the basis of random sampling from different targeted taxpayer groups or all groups. These visits are also typically made by prior appointment during the taxpayer's business hours. In many cases, such audits may have to be conducted at the residence of taxpayers who are either not engaged in a business or profession or who do not have a separate place of business. For residential premises, prior

\footnotetext{
${ }^{12}$ These audits in the United States are under what is known as the Taxpayer Compliance Monitoring Program (TCMP) and are much feared as "audits from hell."
} 
appointments and taxpayer convenience in relation to the times of the appointments should also be considered by the TA.

6.2.2.6 Tax-fraud investigations. These investigations are typically conducted by special units in the TA or even by police-led teams. Such investigations are typically initiated when evidence of potential criminal activity comes to light. Verification of fraud typically results in criminal sanctions being imposed on taxpayers by the judicial system. In several developing countries (and in some developed ones) massive underpayment of taxes is almost always associated with tax fraud, with both coming to light during comprehensive audits. In such cases, follow-up action for comprehensive audits can typically include civil penalty proceedings as well as a separate criminal prosecution. A special type of tax investigation is the tax raid or search, (to be discussed further), which can be undertaken without prior warning to the taxpayer and which can result in the seizure of incriminating documents and material. Different countries have different levels of safeguards against misuse of their powers by TAs.

A model return-processing system from the stage of return receipt to audit is presented in figure 6.1.

\subsubsection{Internal and third-party information availability and use}

The first, pre-audit, stages involve efforts by the tax authority to ensure that all returns required are indeed filed. This activity includes the detection of "ghosts" or nonfilers discussed in relation to TINs. Detection of nonfilers is often an activity whose effectiveness can only be indirectly assessed with reference to business and household data collected for other, nontax, purposes such as general income and business sector statistics. Nevertheless, more specific information can be collected from third-party information reports in which information is available on nonfilers, particularly if TINs are required to be quoted. In fact third-party information reporting is likely to be the most important source of information for the identification of potential nonfilers. In some less developed countries, in-person "surveys" of businesses are conducted mainly to detect nonfilers, this being the only practical means of detecting small businesses that do not comply with their returns-filing obligations. ${ }^{13}$ Once identified, nonfilers are asked to file returns. The next step is receipt and recording of returns. ${ }^{14}$

\footnotetext{
${ }^{13}$ For a discussion and evaluation of surveys and (manual) information matching in relation to thirdparty information in India, see Das-Gupta and Mookherjee 1998.

${ }^{14}$ It should be clear that, in practice, prima facie verification of returns can take place at the same time as nonfiler and stop-filer control activity, especially if these procedures are separate functional activities in the TA. The sequence of steps described follows the logic of the procedure without implying any temporal progression-especially if due dates for return filing by different groups of taxpayers in the tax calendar vary.
} 
FIGURE 6.1 A model audit procedure

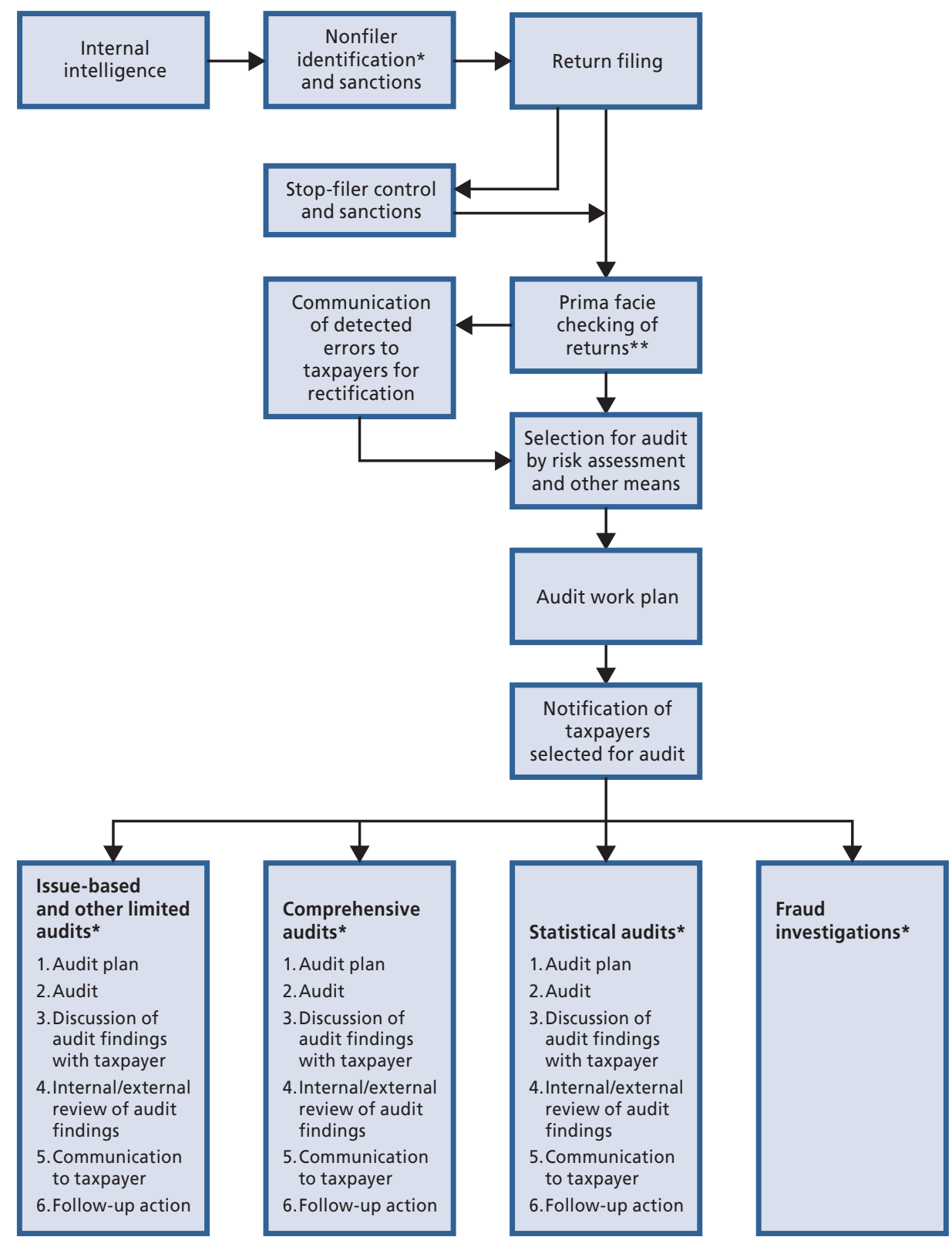

* Partial use of third-party information; ** Extensive use of third-party information.

The second stage in which information is brought to bear is in the identification of stop-filers. The effectiveness of this stage is heavily dependent on the comprehensiveness and reliability of the taxpayer master file and the procedures the tax authority has in place for recording returns as they are received for comparison with the master file. When identified, stop-filers should typically be sent notices requiring them to file returns or to explain why they believe that they are not required to do so. 


\subsubsection{Communication of errors to taxpayers}

After nonfiler and stop-filer control, prima facie desk verifications should typically be undertaken for all or a sample of taxpayers. As discussed, taxpayers should then be contacted to ask them to make good these deficiencies.

\subsubsection{Ranking and classification of cases for audit}

After return-receipt control activities, the next stage is to select returns for issue-based or comprehensive audit. There are a number of potential ways in which such returns can be selected. Ideally, these methods should be used to rank taxpayers according to the extra revenue expected per unit of audit resources used. Note that this is not the same as auditing taxpayers who are identified, potentially, as being the largest tax evaders if, for example, unearthing evidence of such evasion is projected to be difficult. To take another example, given the shorter time and resources needed, an issue-based audit may have a higher revenue-to-cost ratio than a comprehensive audit despite the limited extra revenue likely to result from it. Concern with efficient and effective audits that focus on productive use of time requires, ideally, the prior development of two models. The first is a risk-assessment model, using an estimate of the extra revenue that an audit might result in. The second is a system of norms to estimate the time and resources that will be needed to either conduct an issue-based audit or a comprehensive audit. Ideally, the latter should also take account of expected taxpayer compliance costs. Ranking of taxpayers for issue-based audits will typically rely on prima facie checks and additional third-party information not used in prima facie checks. For risk assessment, a number of standard indicators can initially be used. However, as evidence is accumulated from analysis of audit data from past years (data mining), this evidence should be reflected in the risk-assessment model. A more detailed discussion of risk-assessment information and models follows.

\subsubsection{Preparing an audit work plan}

It is worth reiterating a point made in the discussion taxpayer ranking. The focus of risk-ranking taxpayers should be the extra revenue expected per unit of audit resources used. Furthermore, as has been pointed out, "resources used" should take account of taxpayer compliance costs and not just tax authority costs. What weight is given to taxpayer compliance costs is an issue that should be decided by each jurisdiction, though neither 0 weight nor 100 percent weight is appropriate. ${ }^{15}$ Given

\footnotetext{
15100 percent weight is inappropriate for at least two reasons. Even if, in principle, the view taken is that, society's resources have the same value regardless of who uses them, taxpayer compliance costs will typically be measured less reliably than tax authority costs and less weight should be given to relatively unreliable cost indicators. Second, if taxpayers become aware that their compliance costs have a bearing on their chance of audit selection, they will have the incentive to game the system and deliberately conduct their affairs inefficiently to avoid an audit. A third possible reason arises from the fact that noncompliant taxpayers are the target of audits. Success in dealing with the noncompliant taxpayer has indirect compliance effects on other taxpayers, especially similar taxpayers.
} 
the audit manpower available in the TA, the current period's audit work plan should then be devised, focusing on the highest-ranked cases from which extra revenue is expected.

Not all available audit resources should be allocated on the basis of risk assessment. Some resource flexibility should be allowed to deter potentially noncompliant taxpayers not picked up by existing risk assessment. Audit flexibility recognizes that new information on high-risk cases that should be audited may come to light during the course of the year (if no such information comes to light, extra resources can always be allocated using the risk-assessment ranking later in the year). The percentage of slack that maximizes revenue can only be determined based on past experience and associated data mining. Second, it is important for the tax authority to devote some audit resources to a "sector" audit to improve their knowledge of emerging economic activities or sectors that are undergoing significant changes in their operating procedures or their practitioners. The sector audits should be used to refine the audit selection model and also the audit manual discussed. It should be noted that "sector audits" may be targeted not just at an identifiable sector but also at specific provisions of the income tax law such as, for example, residence requirements, treatment of particular types of payments, and so on. Particularly important for sector audits are high exemptions, concessions, and tax incentives, particularly when they are newly enacted. Third, a small percentage of taxpayers, typically no more than 1 in 1,000 to 1 in 5,000, should be selected purely randomly from among those not found to be high-risk during assessment. This compensates for possible deficiencies in the risk-assessment model and also ensures that all taxpayers are potentially subject to audit. Finally, based on past experience, some slack should be allowed for underestimation of audit resources needed. ${ }^{16}$

Any audit selection system will, of course, also be subject to administrative rigidities such as returns being received on different dates and at different locations. On the part of taxpayers, staggered receipt of returns-particularly from potentially high-risk nonresident taxpayers or, in the case of VAT, temporarily registered sellers such as touring merchants and stall holders in trade fairs-must also be allowed for in audit work plans. Here, to not disrupt audit work, planning a separate audit division for nonresident temporary taxpayers and similar cases is probably the best compromise. A more serious problem is preallocation of auditors to different geographical divisions or field offices of the TA. This could imply, for example, that only a small percentage of high-risk cases are audited in Region A, while even low-risk cases are audited in Region B. The example illustrates how tax authority organizations not organized functionally (possibly within a taxpayer segment structure) can

\footnotetext{
${ }^{16}$ It should be noted that allowance for underestimation of resources can result in tax auditors deliberately stretching out audits unless safeguards against this are built in, ideally through incentives for auditors to complete assigned audit work within the time allotted.
} 
hinder tax authority effectiveness and efficiency. Ideally, audit resources should be allocated centrally in each audit work plan.

The last audit planning issue is the size of the audit division. The practice in many developing countries' TAs is to allocate too many resources to audit at the expense of other vital functions, including information collection and processing, taxpayer services, and dispute resolution. The opposite is possibly the case in many developed jurisdictions such as the United States. As a rule of thumb, TAs should end up conducting comprehensive audits of around 1 percent to 2 percent of taxpayers, with another 2 percent being subject to issue-based audits. ${ }^{17}$

\subsubsection{Notifying taxpayers of selection for audit}

Audits should be distinguished from criminal investigations. They should be viewed as a normal tax authority activity designed to assist taxpayers to correct noncompliance-and should, as far as possible, be nonadversarial. Prior notification to taxpayers of audit selection and, as far as possible, scheduling the audit to suit the taxpayer's convenience, are desirable. Ideally, the audit work planning unit should contact the taxpayer (possibly by phone) to make an appointment to commence the audit. This should be followed up by a notice to the taxpayer that they have been selected for audit and crucially, informing them of what this means and their rights and obligations. In particular, the taxpayer's obligation not to withhold information sought by the audit officer, to deny access to certain parts of the taxpayer's business or residential premises, to be entitled to special safeguards in case minors and persons of the opposite sex are present or involved, and to have the right to involve paid representatives should be covered in the rights and obligations statement.

Noncooperative taxpayers should, of course, be made to pay applicable penalties. In particular, taxpayers contacted to make good errors noticed in prima facie checks or those selected for issue-based audits (along with some comprehensive audit cases) should be unilaterally assessed to tax by the tax authority after a specified time has elapsed. The TA law should provide for such unilateral assessments and associated administrative law should lay down procedures to be followed.

\subsubsection{Second chances}

One procedure that can enable audit resources to be used more efficiently is to follow the British and Colombian practice of giving taxpayers a second chance, following selection for audit, to allow them to voluntarily revise their return before the audit

\footnotetext{
${ }^{17}$ The theoretical prescription is that the marginal efficiency cost of funds (MECF) should be equated across tax authority activities. See Slemrod and Yitzhaki (1998). However, despite some innovative attempts (see Fortin and Lacroix 1994; Snow and Warren 1996; and Poapongsakorn and others 2000), this principle is as yet hard to operationalize for TAs.
} 


\section{BOX 6.1 A Case Study of VAT Audit Procedure for Manufacturing Units in the Department of Customs and Excise, India}

Step 1. Selection of unit for audit: mandatory for large taxpayers and based on risk assessment for others

Step 2. Desk review of the taxpayer dossier containing information or copies of:

a. Items manufactured and rate of duty

b. Number of factories

c. Balance sheet, profit and loss account, and trial balance

d. Duty payment in last three years (from the profit and loss account including details of input credit and capital goods credit claimed)

e. Marketing pattern declaration

f. Major inputs used

g. Sales tax returns

h. Show cause notices issued against the unit

i. Details of pending demands

j. Audit objections during the last two years

Step 3. Study of records and documents and "walk-through" of key features of the unit

a. Obtain list of documents and records maintained

b. Returns filed with other departments

Step 4. Discussion with key personnel in finance, marketing, stores, and production covering:

a. Business organization, major customers, and suppliers; other units under same management

b. Major systems like documentation for purchase, receipt, inspection, stores, sales, and delivery

c. Marketing: major scheme launched

d. Major incidents such as fires, new markets, new products

and pay any additional taxes and interest. If revisions yield taxes within a margin of extra taxes expected from data-mining-based norms, audits can be waived and audit manpower reallocated.

\subsubsection{Audit manuals and audit procedure}

To ensure uniformity in the conduct of audits, clear guidelines identifying nondiscretionary and discretionary steps need to be laid down by TAs. Besides audit procedure, an audit manual needs to provide guidance to audit officers on the conduct of an audit. In jurisdictions where the law views adherence to procedures as important, the importance of clear procedural guidelines cannot be overemphasized: There are numerous cases in which evidence of noncompliance coming to light during an audit has been ruled inadmissible in subsequent tax disputes or tax prosecutions due to the failure of the TA—in particular, audit officers — to adhere diligently to proper procedures.

Therefore, the audit procedure needs to clearly identify the sequence of steps in an audit, paying particular attention to respecting taxpayer's rights and recording the 


\section{BOX 6.1 (continued)}

e. Important reports generated

f. Key input-output ratios

Step 5. Tour of plant and review of internal control

a. Study basics of manufacturing process and verify correct classification of goods including byproducts and scrap

b. Removal of semifinished goods

c. Use of capital goods for exempted products

Step 6. Preparation of audit plan

a. Which areas to be audited (for example, valuation, stores, or sales invoices)

b. Quantum of audit-which months and years to audit

c. Plan must be approved by audit team's supervisors

Step 7. Conduct of audit

a. Integrate the use of a computer-assisted audit program

b. Team generally consists of an audit officer and two or three inspectors

c. Surprise visits by senior officers during audit possible

d. Reliance on financial records including trial balance, balance sheet, cost audit reports, ledger accounts, company auditor's report, invoices, other vouchers and receipts, inventory and production records, other tax returns

Step 8. Discussion of audit findings with unit management

Step 9. Internal presentation to monitoring cell in the tax authority for approval

Step 10. Preparation of audit report and working papers

audit officer's adherence to key steps laid down in the procedure. Contact with taxpayers, informing them of their rights, ensuring that adequate notice is given to taxpayers, scheduling audit meetings or visits at convenient and agreed times, recognizing the role of tax advisors, and providing receipts for any seized books, documents, or physical evidence are some of the key issues the manual should address. Other major issues include guidance on communicating and discussing audit findings with audited taxpayers and guidelines regarding involvement of third parties in audits. ${ }^{18}$

Audit guidelines ideally should provide guidance in key audit steps, illustrated by case studies. A sample audit case study is provided in box 6.1. Guidance notes and checklists in the manual should also lay down steps needed for specific audit procedures.

\footnotetext{
${ }^{18}$ Direct involvement of unrelated citizen witnesses during audit is not often required, unless there are potential problems from allegations of improper behavior in the case of field audits of residential premises. External witnesses are of greater importance during tax raids. A third case of external involvement is citizens' review of adverse audit findings as in Sweden or as was instituted during the tax administration reforms in Mexico in the 1990s. See Bagchi, Bird, and Das-Gupta (1995) and DasGupta and Mookherjee (1998) for more information.
} 
For example, with reference to the case study in box 6.1, checklists and case studies could provide guidance about documentation and information needed when identifying "major systems like documentation for purchase, receipt, inspection, stores, sales, and delivery" or for "surprise visits by senior officers during audit." Third, the manual should provide instructions about how to take account of information identified during risk assessment. The use of IT support in the actual conduct of an audit greatly facilitates adherence to procedures, minimizing intelligence gathering discretion and omissions, and reduced error rates in information processing.

One important procedural aspect is the use of information from risk assessment and its connection to audit. At the time of risk assessment, briefs should be prepared for each case examined identifying potential high-risk areas that formed the basis of the estimate of extra revenue likely to result if the taxpayer was audited. These briefs should also make suggestions as to whether the taxpayer's audit should emphasize mistakes committed, tax evasion, procedural lapses, or some combination of these. The audit manual should specify that the risk assessment brief should be used by the audit officer as an initial plan for the audit, to be possibly modified during a comprehensive audit but typically to be used as the final plan for an issuebased audit.

The audit manual should also contain guidance chapters on risk areas and procedures related to as many specific sectors as possible, drawing on experience gained in sector audits. Similarly, it should contain chapters dealing with problems arising with different exemptions, concessions, and tax incentives.

An important closing step in audit procedure that the manual should provide for is an automatic channel for audited taxpayers to provide feedback on the audit to an independent body. For example, independent feedback could be given in predesigned forms, for example, to an independent citizens' body or to an ombudsman.

\subsubsection{Deficiencies of comprehensive desk audits}

In many developing countries, most comprehensive audits are desk audits conducted in the tax office and not field audits. As such, the only distinction between issuebased audits and comprehensive audits is that the latter become fishing expeditions where taxpayers are required to produce a variety of books and documents for the audit team to examine. Such audits are not very productive as taxpayers can exercise quite a bit of discretion in relation to the books and documents they make available. They are often a source of excessive compliance costs, especially since most taxpayers find it necessary to engage representation to represent their interests during the audits and since audits often require several visits to the tax office. Without adequate 
oversight, these audits also provide the audit officer with the power to harass the taxpayer in order to extract bribes. In view of these problems, comprehensive desk audits ideally should be discontinued. Where they are used, clear guidelines should exist, especially for recording audit proceedings and channels for independent feedback from audited taxpayers.

\subsubsection{Audit infrastructure and IT support}

In terms of infrastructure, one basic requirement is facilities at the tax office for desk audits (and other reasons for which taxpayers visit the tax office). ${ }^{19}$ While the seriousness of security problems varies, tax offices should be designed so that visiting taxpayers have no access to confidential records of themselves or other taxpayers. This obvious requirement is often not met in local offices in developing country TAs, particular where reliance on paper records continues to be important. Ideally, this requires a separate area for visiting taxpayers, with tax authority staff required to leave their work areas and interact with taxpayers only in the designated public area and with controlled access to the nonpublic area. The tax authority also needs to preplan facilities in public areas to ensure that taxpayers and their representatives can wait for their appointments in reasonable comfort. This implies adequate seating and access to basic facilities like toilets and drinking water. Second, for audits, interview rooms should be available so that audit proceedings can be conducted with due regard to taxpayer confidentiality.

In IT-enabled audit offices, password-controlled, networked workstations can be provided. ${ }^{20}$ For field audits at the taxpayer's premises, as well as for desk audits, laptop computers equipped with an audit program are used in many advanced countries. These laptops can contain copies of taxpayer records required for the audit and a program to guide the auditor step by step through the audit. Additional expertsystem modules to provide assistance for particular audit checks are also available. Existing audit software need not be developed in-house, as customizable software is available commercially. Alternatively, such software can be obtained by means of technical assistance contracts from jurisdictions that already utilize them. Providing auditors access, through networked audit computers, to online databases in the tax office is an attractive option with, however, potentially high security risks if the network connection is open to external attack.

\footnotetext{
19 Tax office layout has already been discussed in general terms in this chapter.

${ }^{20}$ To avoid loss of security through human error, the network connection should automatically switch off periodically, say every 10 minutes, if the tax officer does not re-enter his/her password.
} 


\subsubsection{Audit follow-up}

Major post-audit activities should include

- approval of audit findings by designated senior tax authority officials;

- obtaining and processing of feedback by the audited taxpayer as to the conduct of the audit team, adherence by the team to taxpayer-related obligations, the time and money compliance costs incurred by the taxpayer, and the taxpayer's grievances, if any;

- vetting of audit findings by citizen's representatives where this practice is followed;

- communicating audit findings to the taxpayer, including notifying the taxpayer regarding additional tax, interest, and, if accepted by the taxpayer, penalty due;

- conducting penalty hearings or otherwise implementing procedures to impose penalties;

- alerting the TA's investigation and fraud detection unit in case potential fraud or criminal noncompliance is detected during an audit.

\subsubsection{Other audit features}

Other features to which consideration should be given are:

6.2.13.1 International cooperation and joint audits. Given increasing globalization, the importance of nonresident taxpayers and resident taxpayers with foreign-source income is likely to increase. To effectively tackle noncompliance by such entities, cooperation with TAs in other jurisdictions is of importance. To provide a legal framework for this, countries need to set up a network of double-taxation-avoidance treaties with their main economic partners. In particular, these treaties should contain provisions for information sharing and assistance in tax collection as in the OECD's model Double Tax Avoidance Treaty, Articles 26 and 27 (see OECD 2005).

6.2.13.2 Limitation periods. The period during which the tax authority can initiate an audit or to reopen records of an earlier year for examination is subject to local practice and perhaps administrative convenience, though the time limit on fraud should be identical to that laid down under criminal law. Clearly, shorter time limits reduce the psychic and recordkeeping compliance costs of taxpayers.

6.2.13.3 Partial outsourcing of audits. This can be done in two ways. The first is to hire certified accountants who have the required expertise not available in the tax authority as members of the audit team. The second method, as in Mexico, is to require large taxpayers to have their tax returns verified by CAs and make the accountants jointly liable in case of detected noncompliance unless its detection is 
clearly beyond the competence of the accountant (Gil Diaz 1992). The latter may not be acceptable in all countries, especially if penalties on accountants are severe. Nevertheless, since either option can lower tax authority costs without unduly raising compliance costs, their feasibility is worth exploring.

6.2.13.4 Audit effectiveness criteria. The effectiveness of audits should be evaluated in terms of quality as well as the quantity of additional tax or penalty realized. A good indicator is the uncontested additional sums assessed on audit paid by the taxpayer. For disputed assessments, a distinction should be made between disputes that affect only the particular taxpayer and disputes that will result in case law that can affect several tax assessments and taxpayers in current as well as future years. For the former, the appropriate indicator is the additional sums ultimately collected when disputes are resolved by appeals authorities or courts. Disputes that affect whole groups of taxpayers are harder to evaluate and call for case-by-case judgment. The other dimension of performance is cost-efficiency, reflecting taxpayer and tax authority costs per dollar of additional revenue. Since effective audit programs have both direct and indirect compliance effects, this can only be estimated by using appropriate statistical models in addition to taxpayer compliance cost information. ${ }^{21}$

\subsection{Information Used to Assess Risk}

The benefit of an efficient risk-based audit strategy, apart from maximizing the efficiency of the audit process, is a significant reduction of the compliance burden borne by honest taxpayers, as they are audited less frequently.

At the outset, it should be made clear that for TAs using manual procedures, only a few stratification criteria, and perhaps random prima facie checks, will be feasible. The discussion here mostly assumes some available IT support, though certain procedures can also be used (and have been) by TAs which are yet to introduce such support.

Indicators for risk assessment are of four types. First, there are indicators that reflect the general tax potential of different taxpayer groups. These indicators are not the same as indicators of how evasion-prone different groups might be. In fact, if a group of taxpayers is hard to tax, this reduces the extra revenue potential from audit, other things equal, even though such groups may be highly evasion-prone. ${ }^{22}$ Examples of such indicators include:

\footnotetext{
${ }^{21}$ For a review of this and related economic work on tax compliance, see Andreoni, Erard, and Feinstein (1998). For the Indian case see Das-Gupta, Lahiri, and Mookherjee (1998).

${ }^{22}$ For discussions of problems with taxing the hard-to-tax see Alm and others (2004). See also DasGupta (1994) for the exposition of a theory of what makes different groups hard to tax. For a sample of empirical work examining the relation of cross-border activity to tax evasion see Joulfaian (1993), Joulfaian and Rider (1998), and Slemrod and Venkatesh (2002).
} 
FIGURE 6.2 Risk-based assessment

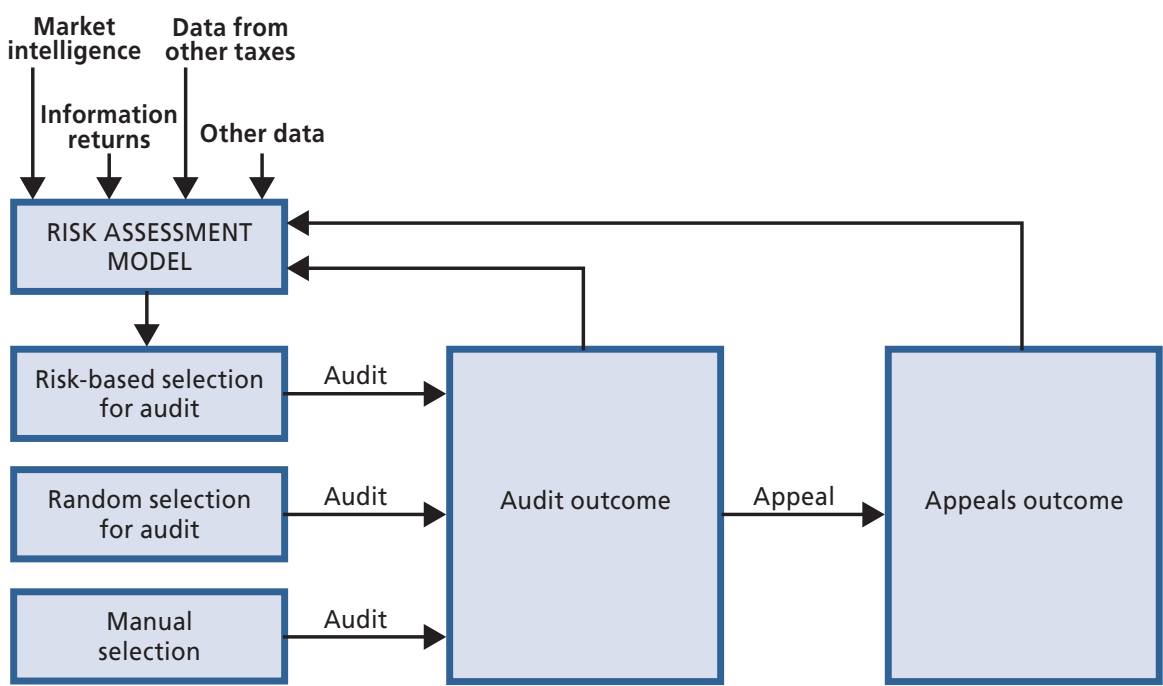

- The extent to which production or income-generation activities can be verified after the fact, and the proportion of cash sales. For example, professional services such as those of doctors and lawyers, and primary production activities like agriculture and on-the-spot services paid for in cash are hard to trace and can frustrate discovery by an audit.

- The bulkiness of goods or duration of a contracted service. For example, buildings and cars or long-term, contracted insurance, transport or maintenance services will be easier to trace than small goods or, as mentioned, on-the-spot services.

- The extent to which production inputs are provided by firms within the tax jurisdiction of the audited entity or sales are to units within the jurisdiction.

Verification of the correctness of reported valuation of cross-border purchases or sales presents difficulties.

The second type of indicator relates to the taxpayer's past behavior, possibly in relation to current behavior. Examples of such indicators include significantly worse current performance than in the past, a history of defective returns or tax evasion unearthed via earlier audits, or a history of unusually low profitability compared to other firms in the industry or unusual losses. In particular, for taxpayers with a history of tax noncompliance, an original paper by Greenberg (1984) presented a scheme for selecting taxpayers for audit using information on evasion detected in the past. ${ }^{23}$

\footnotetext{
${ }^{23}$ Starting with initial random selection, assuming no other risk profiling information is available, taxpayers detected evading taxes would have a much higher probability of being audited for several subsequent years. On the other hand taxpayers not detected to have evaded taxes would have their subsequent audit probability reduced for several future years.
} 
Regardless of the noncompliance reduction benefits, use of past evasion to select audit cases discriminates against past evaders. It can be argued that penalizing detected evaders and not penalizing other evaders also violates horizontal equity.

The third type of indicator relates to deviations of current performance from norms. Standard indicators of this kind, which can progressively be refined through data mining, include indicators based on

- discrepancies revealed by internally cross-checking available informationsuch as in returns filed for different taxes (income taxes, customs duties, property taxes);

- discrepancies and unreported transactions suggested by information obtained from third parties;

- information, particularly accounting ratios and tests, that shows deviations either from past tax returns or from ratios found for similar taxpayers. ${ }^{24}$

For example, using the information in Parker (1990) on accounting tests and procedures used by the UK Inland Revenue, the following list can be suggested:

(i) Correspondence of recorded cash flows with business dealings

(ii) Reconstruction of a taxpayer's accounts using a standard gross profit mark

(iii) Correspondence of bank cash flows with acquisition and disposal of large capital goods or investments

(iv) Unusually low sales compared to purchases or alternatively a high inventory-sales ratio

(v) High ratio of cash sales to sales paid for by other, recorded means

(vi) Low salaries of owners, partners, or directors relative to business profits

From (iv) through (vi), the comparison is made against data for other similar businesses (and also past years).

The fourth type of information is from paid or voluntary informants. The importance and reliability of this source of information will vary in different countries and with the extent to which informants are actively encouraged by the TA. Typically, information from informants is of greater importance for tax fraud and criminal evasion cases than for normal audits.

\subsubsection{Three special categories of taxpayers for risk assessment}

6.3.1.1 New businesses. For new businesses, especially medium and large businesses, education and information visits—rather than audits-initially should be scheduled in the second or third year of operations. However, it is important to keep

\footnotetext{
${ }^{24}$ As can be seen, none of these indicators necessarily require IT support, though the extent to which they can be deployed is IT-dependent.
} 


\section{BOX 6.2 Introducing Risk-Based Tax Audit in the Kyrgyz Republic}

The Kyrgyz Republic, like some other former Soviet Union countries, had a burdensome tax system that imposed high compliance costs on taxpayers. The high incidence of inspections and audits gave inordinate discretionary powers to the tax officials and provided opportunities for rent-seeking behavior. One solution is to introduce a risk-based tax audit that uses a computer model to objectively select the riskiest or most evasion prone taxpayers for audit. This ensures the most efficient use of resources, reduces the tax official's discretion, and thereby reduces corruption.

The model: The focus is on regression-based modeling. The basic equation is

$$
Y=b X+e,
$$

where $Y$ is the predicted audit outcome, $b$ a set of parameters to be estimated, $X$ a set of taxpayers' attributes, and e an error term.

Data on historical audits and attributes of taxpayers is used to estimate the model. Initially, it focuses on taxpayers for whom good quality data is available, in this case, large taxpayers. The data requirements include: General taxpayer information (district, activity code, turnover, date of registration, date of deregistration, date of liquidation); VAT details (all fields in the standard VAT return, including VAT collected on sales, VAT paid on inputs, total VAT due, number of submitted returns per year); profit tax details (all fields from the standard profit return, including turnover, deductibles expenses, taxable profit, total profit tax liability); Tax Payments (all tax payments, per year and per tax type); Audit results; Tax adjustments; Penalties for tax unpaid and/or late payment; Penalties imposed during the audit other than insufficient and late tax payment; Interest tax arrears.

The model works by computing a corresponding risk score for each taxpayer. In this case, the model throws up a predicted audit outcome for each taxpayer; clearly the higher the value of the predicted audit outcome, the riskier the taxpayer. The model proceeds to classify taxpayers by risk groups accordingly. The tax administration can then plan audits per risk group classification. Finally, feedback from new audits resulting from the model is incorporated in the model and it is re-estimated and improved.

The key characteristics of the model in the Kyrgyz Republic are as follows.

The annual turnover is found to be a strong determinant of-and a good predictor of - tax audit results, which reflects a simple size effect: the larger the firm, the larger expected result from an audit is. The growth rate of profits is also found to significantly influence audit results. This appears to be an indicator of a taxpayer making structural changes, which is associated with higher compliance risk. The deviation of the profit rate from the sector mean is a typical explanatory variable used by many tax administrations as an indicator of risk. It also works well here, successfully explaining audit results. Different types of legal status are also found to be associated with different levels of compliance risk.

Source: Charles Vellutini (2009) — Risk based Audit proposal for Kyrgyz republic. FIAS (2009).

Note: This model has not yet been implemented.

track of sectors that tend to attract fly-by-night operators, who can close shop before attracting the TA's attention. The importance of third-party information from bodies such as shop licensing authorities is self-evident.

6.3.1.2 Taxpayers with losses and the hard-to-tax. Taxpayers who may need special treatment include those with negative tax liability (for example, losses, especially 
if they can be carried forward) and hard-to-tax taxpayers. Returns showing losses must be ranked along with other taxpayers but in a special way. During prima facie checking, the magnitude of the tax relief resulting from the loss declared should be noted. Furthermore, for risk profiling other issues, a declared loss should be viewed as a higher-risk case than a return showing positive tax dues. For the hard-to-tax where evidence of tax evasion is unlikely to be easily detected, audits, and thus audit case selection, should focus on the "technical offence" of not maintaining proper records. The cost-effectiveness of audits of such taxpayers can only be estimated from data mining.

6.3.1.3 Tax withholders. Taxpayers who are also withholders should be subject to (potentially) joint audits or issue-based audits that target only selected issues, possibly including, withheld taxes. However, separate audits for taxes owed by the taxpayer and withheld taxes are to be avoided as this imposes excessive compliance costs on the taxpayer. At the other extreme, exclusion of withheld taxes from the scope of regular audit, as is the case in some jurisdictions, leads to a great risk of uncontrolled revenue loss and so should be avoided.

\subsection{Appeals, Grievances, and Tax Prosecutions}

A credible, independent and quick appeal process improves taxpayer's confidence in the tax system, reduces opportunities for illegal tax demands and curbs corrupt practices and extortion by tax officers.

A credible tax assessment appeal process is the cornerstone of an efficient TA. An objective rules-based framework is necessary for TA. An independent appeal process that strengthens the integrity of the tax system and cultivates confidence from taxpayers is an important part of such a framework.

A fair and effective appeal system is necessary because:

- TAs are highly prone to abuse by overzealous and corrupt tax officials.

- The value of taxes due the government frequently involves differences in opinion on the correct tax liability.

- To the extent that it profoundly impacts people's rights, tax collection requires the cooperation of taxpayers for the system to run smoothly.

The appeal system is fairly standard the world over. This is initially through an administrative process within the tax authority and subsequently through the judicial system. The appeal process through the tax authority usually addresses facts, while the judicial appeal usually addresses questions of law. Another appeal system is a tax tribunal that brings together TA and judicial experts. 


\subsubsection{Conditions for a credible appeal process}

Necessary conditions for an appeal process that inspires confidence among its intended users may be summarily described as follows:

6.4.1.1 Independence of appeal officers. A precondition of any credible appeal system is the independence of the appeal bodies. This is difficult in the case when the appeals are heard within the tax authority. With the tax authority being itself a party to the case the first few levels of appeal do not inspire much confidence among taxpayers.

The breach of the principles of natural justice is even more egregious when the first appeal is heard by the tax auditor who prepared the tax assessment, of his/her superior. The supervisor is directly responsible for tax collection, and any appeal against the decision of his/her subordinate is not likely to be viewed favorably.

One way to limit this conflict of interest is to allow the first level of appeal to a person who does not report directly to the supervisor or even the next level. This ensures that the aggrieved taxpayer is first heard by an official who is fairly senior and who is not under direct pressure to meet tax collection targets.

6.4.1.2 Adherence to principles of natural justice. Audi Alterum Partem, the legal principle that means "hear the other party," is the bedrock of the principle of natural justice. It requires that both parties to a dispute-in this case, the revenue authority and the taxpayer-must get an equal opportunity to present their case. This opportunity to present must include equal representation at the hearing/meeting where the decision is to be made with equal opportunities for due process.

6.4.1.3 Reasonable preconditions for filing appeal. The decision by the taxpayer to appeal is subject in many countries to the payment of some or all the disputed tax. In some countries where this is not required, taxpayers are expected to pay the tax amount along with market rates of interest as soon as they lose their appeals.

6.4.1.4 Time-bound appeal process. A key requirement must be efficiency of the dispute resolution process for both the taxpayer and the TA. The appeal process must be time-bound, thus resulting in speedy resolution of appeals. This will ensure first, that taxpayers do not have funds tied up in disputed taxes for inordinately long periods, and second, but no less important, that the revenue authority and the state are not deprived of taxes that are due to them.

6.4.1.5 Progressive selectivity. The tax appeal system must result in effective resolution of the majority of cases at the lowest levels of the dispute resolution structure. One way of ensuring progressive selectivity is to prevent cases primarily dealing with questions of fact from proceeding beyond the level of a tax tribunal. 
FIGURE 6.3 The independence of appeal officers

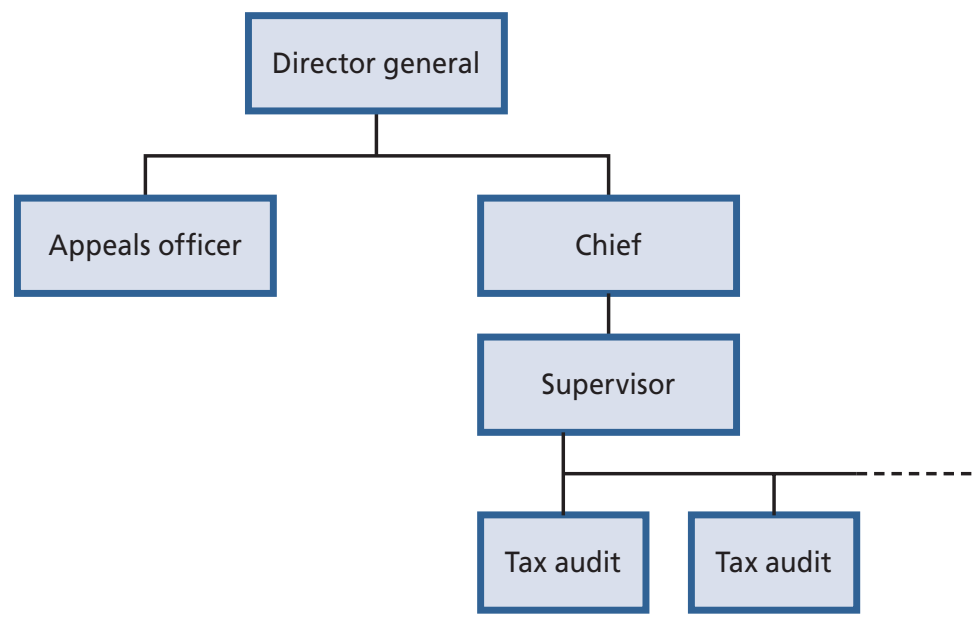

Only those tax disputes that involve significant questions of law should be permitted to go up to the higher levels of the judiciary. Following this principle ensures the tax dispute resolution structure is more effective and efficient: the higher courts do not have to spend valuable time and resources on disputes that may not involve high tax amounts or complex legal issues. Consequently, the tax authority will not expend resources to argue cases that are not the subject of technical or novel legal issues.

A policy which blends the necessary components described above to achieve optimal benefits for the tax authority and non-onerous burdens for the tax payer will invariably yield better results than a system which assumes an adversarial relationship between the tax authority and the tax payer.

The requirement to pay some amount of the disputed tax when filing an appeal is deemed a necessary condition because taxpayers would otherwise game the system. In countries where the appeal process takes a long time, taxpayers could deliberately underreport to tax authorities, taking advantage of the time delay, with the hopehowever slight - that they might be exonerated at a later date. This could create cashflow problems for government. It is also possible that, during the intervening period, such a taxpayer will close down his/her business, leaving the tax dues unpaid.

Where taxpayers have to pay only the disputed tax liability, including market interest, this may encourage frivolous appeals to delay payment of taxes, since taxpayers bear little or no cost to do so.

But the other extreme of paying the entire tax amount is not the solution, either. There is always a chance that the taxpayer may win either fully or partially on 
appeal; expecting him/her to pay the entire disputed tax amount could create cashflow problems. This may compel taxpayers to forgo their rights and settle with tax officials in order to avoid large tax liabilities that they legitimately believe will be resolved in their favor-but only after a considerable period of time.

\subsubsection{The TA and the appellate process}

Coercive powers of TAs to deal with noncompliance are discussed in the next section. This section deals with the further interaction between taxpayers and the tax authority after an initial determination of their tax dues by the TA, leaving aside cases where TAs must bring to bear their coercive powers. Before presenting a classification of these interactions, the general principal a tax authority should keep in view should be clearly understood. A TA's objective is to maximize its effectiveness and efficiency: If a particular taxpayer interaction should be terminated in the interest of achieving greater effectiveness or efficiency, this should be done. Continuing a TA-taxpayer interaction should be based on a cost-benefit test where the expected extra revenue benefit outweighs the TA's and taxpayer's expected extra cost by a sufficient margin. If not, the TA's limited resources are better deployed to other tax authority functions. Examples in which TAs do not follow this precept are not hard to come by-a common example is the case of tax appeals with little eventual revenue potential being followed through all stages of a lengthy dispute resolution procedure merely because the tax authority is of the opinion that its position in the tax dispute is the correct one. A second example is of a tax authority choosing to go through formal dispute resolution mechanisms when potentially cheaper mechanisms exist.

These TA-taxpayer interactions potentially fall into eight groups. These are listed in table 6.1, together with organizational channels that should be used to bring them to a close. This is followed by a discussion of key features of different channels.

Two features should be noted regarding table 6.1. First, it does not discuss steps needed to deal with tax authority officials determined to be accountable for the TA's continued interactions. This is particularly important in the context of taxpayer grievances determined to be genuine and for errors made by the tax authority in relation to its determination of additional taxpayer compliance requirements. Second, in the case of disputed tax dues, one way to forestall costly tax disputes is to institute a system of advance rulings available to taxpayers before they file their tax returns. The latter is further discussed below.

Briefly, the structure envisaged in table 6.1 contains six parallel grievance, dispute resolution, or prosecution channels. For taxpayer grievances or mistakes made by the tax authority (rows 1 to 3 in the table), internal tax authority procedures to resolve taxpayer problems should normally be sufficient. The existence of an independent tax ombudsman, an institution pioneered in Sweden, provides an independent recourse 
for taxpayers who are dissatisfied with the way they have been dealt with by the TA. In some developing countries with tax ombudsmen, the office has been particularly effective in identifying cases of corruption in the TA.

The second set of channels is needed in the case of tax disputes (rows 4 and 5 in the table). Resolution of tax disputes usually requires three stages. The first involves an independent division, typically within the tax authority, that the taxpayer can approach to resolve the dispute. Appeals proceedings usually have a quasi-judicial character and typically are costly for both taxpayer and TA. This is usually supported by a second appeals stage, usually through an independent tax tribunal. Tribunals (or benches of tribunals) are usually experts in tax law and due process and are typically not employed by the TA. This second appeals stage enters the picture if taxpayers believe that the decision handed down in the administrative appeal was erroneous. It also provides a forum for the tax authority to file a counter appeal if it believes that the first appeal decision was erroneously in favor of the taxpayer. The tribunal should be the highest adjudicating authority when the tax dispute relates to a matter of fact. ${ }^{25}$ Therefore, when a tax dispute affects several taxpayers, the tax authority should ensure that a binding ruling is available from the tribunal. If, however, the appeal process promises to be long and costly, the tax authority should try to save costs by getting the taxpayer to agree to independent binding arbitration. The tax law should permit this and a procedure for binding arbitration should be instituted. This has been done in several advanced jurisdictions.

There are three potential problems with appeals procedures. The first is the possibility of taxpayers using the appeals process to defer their tax due. The likelihood of such abuse increases if:

- Fees prescribed to file an appeal are too low.

- Adjournments of appeals proceedings do not impose additional costs on the taxpayer.

- The taxpayer has full control over the content of the tax dispute or appeal.

To avoid this problem, appeal admission fees should reflect the cost of providing the service to the taxpayer or (for second appeals) to the TA, with procedures requiring that final appeals costs must be apportioned between the taxpayer and the TA. To deter adjournments, a separate adjournment fee should also be instituted.

\footnotetext{
${ }^{25}$ For example, did actions taken by the taxpayer provide evidence that he/she exercised due diligence and so cannot be subject to noncompliance sanctions? To elaborate further, suppose a taxpayer approaches the tax authority for a required clearance that requires fact-finding by the TA five minutes before the deadline for obtaining the clearance? Does this constitute noncompliance subject to noncompliance sanctions? Alternatively, what if a taxpayer claims ignorance of a compliance requirement announced by the tax authority hours before the taxpayer filed her/his tax return: is this noncompliance?
} 
TABLE 6.1 Organizational channels for TA-taxpayer interaction

\begin{tabular}{|c|c|c|c|}
\hline & Type of TA-taxpayer interaction & Normal channel & $\begin{array}{l}\text { Alternative, less } \\
\text { costly channel }\end{array}$ \\
\hline 1 & $\begin{array}{l}\text { Taxpayers who are aggrieved by the } \\
\text { behavior or conduct of tax authority } \\
\text { officials }\end{array}$ & $\begin{array}{l}\text { 1. Internal grievance redress } \\
\text { procedure (taxpayer } \\
\text { service) } \\
\text { 2. External tax ombudsman }\end{array}$ & - \\
\hline 2 & $\begin{array}{l}\text { Taxpayers who are aggrieved because } \\
\text { they face genuine difficulties in } \\
\text { complying with further compliance } \\
\text { requirements imposed on them } \\
\text { by the tax authority (for example, } \\
\text { request for permission to pay } \\
\text { additional taxes levied in installments) }\end{array}$ & $\begin{array}{l}\text { 1. Internal tax authority } \\
\text { unit tasked with } \\
\text { resolving such problems } \\
\text { 2. External tax ombudsman }\end{array}$ & - \\
\hline 3 & $\begin{array}{l}\text { Taxpayers who do not agree with } \\
\text { the taxes or related levies the TA } \\
\text { has determined they owe because } \\
\text { they believe the TA has committed } \\
\text { a prima facie error (for example, a } \\
\text { failure to take account of all relevant } \\
\text { documented facts or because of an } \\
\text { arithmetic error) }\end{array}$ & $\begin{array}{l}\text { 1. Internal tax authority } \\
\text { unit responsible for tax } \\
\text { assessments. } \\
\text { 2. External tax ombudsman }\end{array}$ & - \\
\hline 4 & $\begin{array}{l}\text { Taxpayers who do not agree with } \\
\text { the taxes or related levies the tax } \\
\text { authority has determined they } \\
\text { owe because they believe the } \\
\text { tax authority has committed an } \\
\text { error in relation to the facts and } \\
\text { circumstances of their case }\end{array}$ & $\begin{array}{l}\text { Taxpayer appeal to the } \\
\text { highest body with the } \\
\text { power to adjudicate on } \\
\text { matters of fact }\end{array}$ & $\begin{array}{l}\text { Binding arbitration if } \\
\text { the taxpayer agrees }\end{array}$ \\
\hline $4 a$ & $\begin{array}{l}\text { Cases as in item } 4 \text { above, in which } \\
\text { the tax authority estimates will help } \\
\text { resolve many other current and } \\
\text { possibly future tax disputes }\end{array}$ & $\begin{array}{l}\text { Taxpayer appeal to the } \\
\text { highest body with the } \\
\text { power to adjudicate on } \\
\text { matters of fact }\end{array}$ & - \\
\hline
\end{tabular}

Regarding the content of the tax dispute, at the stage of first appeal, this should not be within the control of the taxpayer. Instead, the appeal authority should be tasked with reopening the entire assessment of the taxpayer - not just the disputed part. ${ }^{26} \mathrm{~A}$ second problem arises if the appeal authority does not rule on the dispute but sends the appealed case back to the TA for reassessment. This problem is automatically avoided if the authority is required to reassess the taxpayer. The third problem arises if a tax authority files a second appeal even if there is no net revenue benefit from filing the second appeal. To avoid this TAs should have strict cost-benefit assessment guidelines in place, subject to oversight by external government performance audit.

${ }^{26}$ This is the practice in Singapore. 
TABLE 6.1 (continued)

\begin{tabular}{|c|c|c|c|}
\hline & Type of TA-taxpayer interaction & Normal channel & $\begin{array}{l}\text { Alternative, less } \\
\text { costly channel }\end{array}$ \\
\hline 5 & $\begin{array}{l}\text { Taxpayers who do not agree with } \\
\text { the taxes or related levies the tax } \\
\text { authority has determined they owe } \\
\text { because they disagree with the TA's } \\
\text { interpretation of tax law }\end{array}$ & $\begin{array}{l}\text { Taxpayer appeal to the } \\
\text { highest body with the } \\
\text { power to adjudicate on } \\
\text { matters of law }\end{array}$ & $\begin{array}{l}\text { 1. Advance rulings } \\
\text { 2. Binding arbitration } \\
\text { if the taxpayer } \\
\text { agrees }\end{array}$ \\
\hline $5 a$ & $\begin{array}{l}\text { Cases as in item } 5 \text { above, in which } \\
\text { the tax authority estimates will help } \\
\text { resolve many other current and } \\
\text { future tax disputes }\end{array}$ & $\begin{array}{l}\text { Taxpayer appeal to the } \\
\text { highest body with the } \\
\text { power to adjudicate on } \\
\text { matters of law }\end{array}$ & Advance rulings \\
\hline 6 & $\begin{array}{l}\text { Taxpayers in whose case the tax } \\
\text { authority believes noncompliance } \\
\text { has taken place that requires the } \\
\text { application of civil sanctions }\end{array}$ & $\begin{array}{l}\text { Unit responsible for the } \\
\text { levy of civil penalties, } \\
\text { usually internal to the TA }\end{array}$ & - \\
\hline 7 & $\begin{array}{l}\text { Taxpayers in whose case the tax } \\
\text { authority believes noncompliance } \\
\text { has taken place that requires the } \\
\text { application of criminal sanctions }\end{array}$ & Criminal courts & $\begin{array}{l}\text { Out-of-court } \\
\text { settlement/ usually } \\
\text { internal procedure } \\
\text { for "compounding" } \\
\text { of sanctions }\end{array}$ \\
\hline $7 a$ & $\begin{array}{l}\text { Cases as in item } 7 \text { above, in which } \\
\text { the tax authority estimates that there } \\
\text { will be a significant deterrent effect } \\
\text { on other taxpayers }\end{array}$ & Criminal courts & - \\
\hline 8 & $\begin{array}{l}\text { Taxpayers who come forward } \\
\text { voluntarily to confess to former } \\
\text { noncompliance }\end{array}$ & Criminal courts & $\begin{array}{l}\text { Out-of-court } \\
\text { settlement/usually } \\
\text { internal procedure } \\
\text { for "compounding" } \\
\text { of sanctions }\end{array}$ \\
\hline
\end{tabular}

Source: Arindam Das-Gupta 2008.

The additional issue of whether the taxpayer should be required to pay all or part of the disputed taxes before or after the dispute is resolved was addressed above. The tax authority should have a procedure that can, however, be modified by the appeal authority. ${ }^{27}$

Regarding appeals procedures, in many jurisdictions tax appeals rely on oral hearings to respect the right of the taxpayer "to be heard." 28 Hearings are a costly process and subject to abuse. Therefore, ideally, the tax law should provide that certain classes of relatively simple disputes can be adjudicated ex parte without the need for oral hearings.

\footnotetext{
${ }^{27}$ Further discussion is available in Gordon (1996).

${ }^{28}$ This is often, however, considered to be a basic taxpayer right. See Gordon (1996).
} 
The same set of channels should typically also be tasked with initially looking at disputes that relate to interpretation of the tax law (or, for example, laws relating to penalty imposition or other matters). The same considerations as in the case of disputes regarding matters of fact arise, except that the highest adjudicating authority for interpretation of tax laws is usually part of the country's normal court system or, in some countries, a dedicated tax court.

However, one additional channel to forestall disputes can reduce tax authority costs and taxpayer compliance costs. Taxpayers and tax authorities often find complex provisions of the tax code hard to interpret. Since different interpretations can lead to future disputes, a procedure for advance rulings before the taxpayer files tax returns is often available in many jurisdictions. In some jurisdictions, such as the United States, multiple types of advance ruling exist. The power to make binding advance rulings can be within the tax authority or via an independent quasi-judicial body. In the former case, a second, binding stage may be needed. As with binding arbitration, independent advance rulings should be binding on the taxpayer and TA.

On the substance and approach of courts in interpreting tax laws, practices differ substantially in different jurisdictions. ${ }^{29}$ The major point of difference is whether courts interpret tax laws literally or consider the intended purpose of the legislation. This difference in practice is crucial as it can determine the scope and nature of tax avoidance activities by taxpayers. The key considerations are how literally tax laws are interpreted; and if the substance or the form of taxable transactions are considered; and if the economic impact of a transaction is material or not. Given the approach of a jurisdiction's courts to the interpretation of tax laws, the TA's task in countering tax avoidance is typically facilitated in part through the enactment of anti-abuse provisions in tax laws. Nevertheless, in different situations court rulings give rise to case law that apply to specific situations. Much of the application of tax laws depends on case law, which greatly complicates the assessment duties of a TA dealing with sophisticated large taxpayers. No general prescriptions are available to counter these problems; each jurisdiction will have to tailor its strategy taking into account the approach of the courts and the existing body of case law.

A useful aid in assessment audits and combating tax avoidance is a searchable database of case law.

The third set of channels concerns noncompliance by taxpayers not amounting to criminal offenses but subject to civil penalties (row 6 in table 6.1). Imposition of penalties should be internal to the TA, subject to agreed procedure. Imposed penalties should be subject to appeal.

${ }^{29}$ The brief discussion here relies on Vanistendael (1996). 
The final set of channels concerns cases of criminal noncompliance (rows 7 and 8 in table 6.1). Here the point made at the start of the section can be reiterated: The role of the tax authority is to collect revenue effectively and efficiently, not to visit retribution on tax offenders. Therefore, except for the most heinous tax offenses or cases that are assessed to have a large indirect deterrence potential, out-of-court settlement of tax prosecutions on payment of a monetary consideration, a procedure referred to as "compounding" in some jurisdictions, is to be advocated. Other than this, prosecution of criminal cases is usually outside the normal purview of a tax authority and under the jurisdiction of the normal criminal court system.

An institution often known as a settlement authority (common in India and Pakistan, for example) determines the tax liability of taxpayers who voluntarily confess to past noncompliance. These bodies can reduce the penitent taxpayer's liability, they provide a type of amnesty. Therefore, their direct revenue benefits should be carefully weighed against their indirect impact in encouraging noncompliance.

One important issue in the case of criminal tax fraud relates to the onus of proof that a criminal tax offence has indeed been committed. In normal criminal law, different sanctions apply to harm caused by accident or negligence rather than by intention. Providing evidence of intention is typically the responsibility of the prosecution or accuser. In the case of tax crimes, in most jurisdictions such guilt is presumed; proving lack of criminal intent is the taxpayer's responsibility. The justification for this is that relevant evidence is available to the taxpayer, not to the TA. ${ }^{30}$

In evaluating the TA's effectiveness in relation to tax disputes, three considerations are important. The first is the consistency with which tax disputes are resolved-the TA's credibility. If there is no systematic study of different taxpayer outcomes, credibility can be evaluated only through independent feedback from taxpayers, their advisors, and taxpayer associations. (Jurisdictions that rely on general court systems rather than specialized tax tribunals and courts are prima facie less likely to be credible.) The second evaluation criterion is the time taken for tax disputes: In many jurisdictions these can be lengthy and are in urgent need of reform and streamlining. The third criterion is the effectiveness of the TA in relation to other activity. A possible indicator here is the extra revenue collected by the tax authority from tax disputes per dollar of outlay. ${ }^{31}$

\footnotetext{
${ }^{30}$ See Gordon (1996).

${ }^{31}$ This indicator has two drawbacks that are difficult to correct. The first pertains to the indirect impact of the tax authority following up tax disputes and prosecutions - this can, in principle, be estimated by indirect statistical analysis of the direct and indirect impact. The more serious problem is that the measure provides no information on the proportion of cases that should have been followed up by the TA but were not (Type I error). This problem is difficult to overcome.
} 


\subsection{Coercive Power to Tackle Potential Tax Noncompliance}

In addition to the power to collect information from taxpayers and third parties, including via tax raids, most TAs are also provided with a variety of other powers, such as to;

- Issue permissions and certifications that taxpayers require to conduct their businesses

- Levy administrative penalties

- Collect delinquent taxes.

These powers, and procedures that should be followed in the exercise of such powers, are discussed here.

\subsubsection{Tax raids}

For tax fraud and tax evasion, TAs may need to conduct tax raids, despite their intrusiveness. ${ }^{32}$ To ensure no abuse of this power, a legally binding code of procedure for the conduct of tax raids is drawn up in most advanced jurisdictions. ${ }^{33}$ The code of procedure deals with an array of relevant issues including (i) warrants or other authorization needed for searches - usually requiring authorization by a senior tax authority official or the courts; (ii) composition of the search team, including the minimum rank of its leader and, if needed, armed persons and requisitioned police protection; (iii) requirements to have independent external witnesses present during the search-a crucial safeguard against abuse of power; (iv) times and places where the search can be conducted, including premises of third parties; (v) treatment of persons (taxpayers and company employees or their representatives present during the search, particularly minors and women, paying particular attention to the right of the search team to detain parties during the search); (vi) search procedure, including for forcible access to locked rooms or items; (vi) proper recording of search chronology and events; (vii) the extent of coercion permissible in the interrogation of persons; (viii) recording and witnessing of statements made by searched persons; (ix) sealing of items or rooms and seizure of books, documents, valuables, or other items deemed to have evidentiary value; (x) provision to the taxpayer of receipts for seized items; (xi) procedure in case of suspended raids - for example, if the search extends for more than a day; (xii) postsearch reporting requirements; and (xiii) time limits for the retention of seized items and for processing evidence found during searches.

\footnotetext{
32 The use of tax raids and prosecutions as general enforcement tools against otherwise elusive criminals who are detected to have evaded taxes is not discussed here.

${ }^{33}$ Examples of excessive use of search and seizure powers by TAs are many. A celebrated case is the Rossminster case in the United Kingdom in 1982, which led to the creation of the Lord Keith Committee to review the powers of the UK's Inland Revenue. See H.M. Government (1983). To take another example, reporting of excessive use of raids by the U.S. Internal Revenue Service can be found in Public Broadcasting Service (USA) (1999) and the New York Times 1998. In some developing countries, the use of search powers is more extensive, though not as widely publicized.
} 
Sources of information leading to raids are usually informants, third partiesincluding during the course of other tax and nontax investigations-and internal information, including from issue-based or comprehensive audits. It should be emphasized that tax raids should be conducted by the tax authority only if they have an adequate rationale in terms of additional (direct and indirect) revenues in relation to tax authority and taxpayer costs. ${ }^{34}$ A final question in connection with raids relates to the subsequent assessment of taxes due from raided taxpayers. Given that sensitive security issues are often involved in these cases, these assessments are often carried out by special units in the TA.

\subsubsection{Bankruptcy and delinquent taxes}

Besides failure to register, failure to file returns, and failure to correctly report the tax base or taxes due, the fourth important type of noncompliance is failure to pay taxes owed. Coercive measures for recovery of delinquent taxes require, as with other coercive powers, clearly established procedures to prevent unjustified harassment of taxpayers including requiring judicial permission for extreme measures. The procedure should specify that forced recovery proceedings should be instituted only after initial attempts to obtain voluntary payment from taxpayers have been tried without success. ${ }^{35}$

Methods of tax recovery available to the tax authority include liens, property seizure, closure of business premises, recovery from third parties, and seizure of a business, operation by a court-appointed receiver, and compulsory acquisition of property in case of a transfer without due payment of taxes. Other methods are listed in box 6.3 .

In the case of bankruptcy declared by a tax debtor, most countries provide that the government has the first charge on the debtor's assets as a means of recovering taxes and other dues to the government.

Speedy tax recovery is particularly important from nonresidents or residents who are at risk of leaving the country. To close this potential source of leakage, two methods are important:

- Requiring residents to withhold taxes and making withholders liable for taxes that are not withheld;

- Requiring such taxpayers, particularly nonresidents, to obtain "sailing permits" from the tax authority as a precondition for being granted permission to leave the country.

\footnotetext{
${ }^{34}$ For econometric evidence that this was not the case in India during the 1980s and 1990s, see DasGupta, Lahiri and Mookherjee (1995).

35 In Canada, recovery procedures follow an evocatively called "dunning cycle" whereby initial contact is via a polite phone call, followed by a notice to the taxpayer. Coercive procedures are instituted if these taxpayer-friendly measures fail to have an effect.
} 


\section{BOX 6.3 Enforced Tax Debt-Collection Powers in 43 OECD and Non-OECD Countries}

1. Make payment arrangements (42 countries)

2. Collect from third parties (42 countries)

3. Arrange seizure of debtors' assets (42 countries)

4. Grant further time to pay (40 countries)

5. Offset debits on tax credits (40 countries)

6. Obtain lien over assets (35 countries)

7. Initiate bankruptcy (35 countries)

8. Tax clearance for government contracts (32 countries*)

9. Impose tax debts on company directors (31 countries)

10. Withhold government payments to debtor (29 countries*)

11. Bar debtors from government contracts ( 25 countries*)

12. Close business or cancel the business license (18 countries)

13. Restrict overseas travel by debtor (16 countries)

14. Publish names of debtors (12 countries)

15. Deny access to government services ( 6 countries*)

Source: OECD 2006, table 19.

Note: Court order required in some countries; restrictions on certain powers apply in others.

* Information available for 42 countries.

Effective implementation of the latter procedure requires established channels of cooperation with border control authorities. In case the tax authority fails to recover taxes from nonresidents who reside in double-taxation-avoidance treaty partner countries, it is useful if the treaty provides for mutual assistance in collection of taxes via a provision similar to the OECD Model Tax Treaty's Article 27 (OECD 2005).

For third-party recovery methods to be effective, there must be an adequate system of penalties for third parties who fail to comply.

\subsubsection{Closing tax accounts}

Though strictly speaking the issue of closing a tax account does not require the tax authority to use coercive powers, a procedure to close tax accounts is necessary whether or not there are unrecoverable taxes due. Unrecoverable tax dues arise when the taxpayer cannot be traced, is no longer within the TA's jurisdiction, is bankrupt, or is deceased with no recoverable assets. For tax dues that cannot be recovered despite the TA's best efforts, a procedure is required for tax write-offs and closure of the taxpayer's account with the TA. Other instances requiring closure of 
tax accounts include cessation of a business or other entity, mergers and amalgamations of companies, cases where the family, rather than the individual, is subject to income tax, and changes in family status leading to the emergence or cessation of taxpaying entities.

\subsubsection{Tax permissions and clearances}

To forestall noncompliance or to ensure that the tax authority has information about special circumstances applying to particular taxpayers, advance permission or tax clearances are required by TAs in a variety of situations. Such clearances and permissions are particularly important where a taxpayer claims entitlement to concessional taxation. Key examples are permissions to claim exempt status or entitlement to specified tax concessions; exemption from withholding requirements, either on the part of the potential withholder or the withholder; clearances for movement of goods and persons in and out of special zones such as free-trade zones (FTZs); advance assessment and collection of tax (for example, VAT) and duties (for example, customs) from small or occasional importers or exporters at border checkposts before permitting movement of traded goods; and advance clearance for the transfer of highvalue assets at the declared value. While useful to the tax authority in safeguarding revenue and in ensuring that TA interests are safeguarded, such permissions invariably impose additional compliance costs on the taxpayer. In some instances, costs can arise if the procedures for granting permissions are lengthy. Consequently, in all such cases, internal and external monitoring of the process by which permission is granted is important.

One interesting use of advance permission is in relation to property transfers where the risk of undervaluation to evade taxes (property transfer taxes and capital gains) is thought to be high. In these cases, the transferor is required to declare the value at which he/she proposes to effect this transfer. The tax authority then has the right to compulsorily acquire the property at a consideration related to the declared transfer price. ${ }^{36}$

\subsubsection{Comprehensive penalty structures}

To enable the tax authority to deter noncompliance and for its coercive powers to be effective, comprehensive penalty structures are required. ${ }^{37}$

\footnotetext{
${ }^{36}$ While such preemptive acquisition can deter property undervaluation, the success of this strategy depends on, first, the transparency of acquisition proceedings and, second, an adequate procedure for subsequent disposal of acquired property. For example, this was tried in India during the 1990s, but had to be discontinued due to a large inventory of acquired but unsold properties that put a great burden on government resources.

${ }^{37}$ Useful discussions of penalty design are in Oldman (1965) and Gordon (1996). See also Bagchi, Bird, and Das-Gupta (1995).
} 
Six features of such penalty structures are worth noting.

(i) Civil penalties should be paralleled by criminal fines and possibly jail sentences, since most methods of tax noncompliance have criminal counterparts (the only material difference relating to the state of mind of the taxpayer).

(ii) Penalties should cover both noncompliance and technical offenses (such as failure to maintain required books).

(iii) Penalties should not be too low, as there is evidence that penalties are ineffective below a certain threshold (Gordon 1996). On the other hand, if penalties are too high, the can be perceived to be disproportionate to the noncompliant act.

(iv) Penalties should follow the principle of marginal deterrence (Mookherjee and Png 1994), that is they should be progressive to encourage taxpayers to avoid noncompliance.

(v) Penalties should be lower for acts committed due to negligence than for those arising from willful noncompliance.

(vi) Second and subsequent offenders should be assessed higher penalties than first-time offenders.

\subsubsection{Rewards}

Two types of rewards for citizens can assist the tax authority in combating noncompliance. The first is a system of rewards for informants whose information results in noncompliance being detected and proved. The second is a special tax rebate or a "good taxpayer" prize for taxpayers whose tax affairs are in order for a specified number of years. While tax rebates for proper payment of taxes are not prevalent in any jurisdiction (to our knowledge) awards for good citizenship are awarded in some jurisdictions.

\section{Further Guidance}

Richard M. Bird and Milka Casangera de Jantcher. 1992. Improving Tax Administration in Developing Countries. Washington: International Monetary Fund. 


\section{Chapter 7: Fiscal Incentives and Investments}

\section{CHECKLIST OF GOOD PRACTICES}

$\checkmark$ Tax incentives are used minimally and mainly to address market failures and generate multiplier effects

$\checkmark$ If they are to be provided, tax incentives are offered through the law and in a nondiscretionary manner

$\checkmark$ If they are to be provided, tax incentives should, as far as possible, be linked to the investment level, and tax holidays should be avoided

$\checkmark$ The Tax Administration administers investors who benefit from tax incentives to prevent leakage

$\checkmark$ The tax expenditure statements are prepared on a regular basis to measure the costs of the tax incentives

$\checkmark$ Indirect costs of tax incentives are taken into consideration when designing policy

$\checkmark$ Regional cooperation/coordination should be encouraged to prevent harmful tax competition

Investment incentives typically take the form of measurable economic advantage afforded to specific enterprises or categories of enterprises in order to steer investment into favored sectors and/or regions, or to influence the character of investments made in a country. ${ }^{1}$ Such incentives include tax concessions as well as loans and rebates to support business development and enhance competitiveness.

While it is true that many governments have, at one time or another, offered incentives to attract investments, whether or not such incentives have succeeded is not easily answered. ${ }^{2}$ This chapter considers what investment regimes attract investment and propel enterprises to grow, with focus on the following issues:

\footnotetext{
1 The U.S. Government defines it as "Revenue losses attributable to provisions of the Federal tax laws which allow special exclusion, exemption, or deduction from gross income or which provide special credit, preferential rates of tax or a deferral of tax liability."

2 Please see Eric Zolt on Tax Incentives, Presentation to FIAS, January 29, 2008.
} 
- How Tax Incentives affect investment

- The political economy of tax incentives

- How tax incentives have performed in developing countries

- Managing tax incentives

- Measuring the costs and benefits of tax incentives

\subsection{Tax Incentives and Investment}

The effectiveness of tax incentives in promoting investment has been the subject of intense debate in several countries and academic communities. While there is some agreement that tax incentives may indeed increase the profitability of investments and therefore should attract investment, several questions need to be answered. First, do benefits outweigh direct and indirect costs (including the extra burden of those not eligible for them), the opportunities for tax planning, and the resultant economic distortions? And should tax incentives be used in the first place to make up for deficiencies in the investment climate?

The purpose of this chapter is to set out what should be policy makers' principal considerations before awarding any tax incentives and to provide guidance on the administration of tax incentives. Prior to that, however, it is useful to outline the broad conclusions of the literature on the role of tax incentives in promoting incentives.

Hassett and Hubbard (2002) provide a very good review of the literature on the effectiveness of tax policy (in general) and tax incentives (in particular) in promoting investment. Their general conclusions, briefly reviewed, are as follows:

- Tax policy affects investment with an increase in user cost of capital ${ }^{3}$ by 1 percent, decreasing investment to the tune of 0.5 percent to 1 percent (or an elasticity of -0.5 to -1.0 ). This analysis uses microeconomic data of firms. There is, however, little evidence from macroeconomic data that tax policy has any effect on investment. However, this conclusion is likely due to significant measurement errors in macroeconomic data, interasset reallocation of capital, and simultaneity-errors that make it very difficult to draw any causal link or make correct attributions.

- Taxes increase the user cost of capital, so any uniform reduction in that user cost should encourage capital. Targeted incentives are unlikely, however, to achieve such broad-based reduction in cost of capital.

\footnotetext{
3 User Cost of Capital is the cost of capital investment which incorporates all the costs such as interest and taxes as well as the incentives such as investment allowances, investment tax credits and accelerated depreciation, and so on.
} 
- Investment incentives are generally provided to investments in equipment, creating inter-asset distortions among different types of capital. These distortions could outweigh the benefits from the award of such incentives.

- Economic growth is higher in countries that invest more in equipment. This is primarily through the effect of workers learning better skills by operating different kinds of equipment. Hence, subsidizing equipment is good for growth as it generates positive externalities.

\section{BoX 7.1 Fiscal Policy Effectiveness and the Investment Climate}

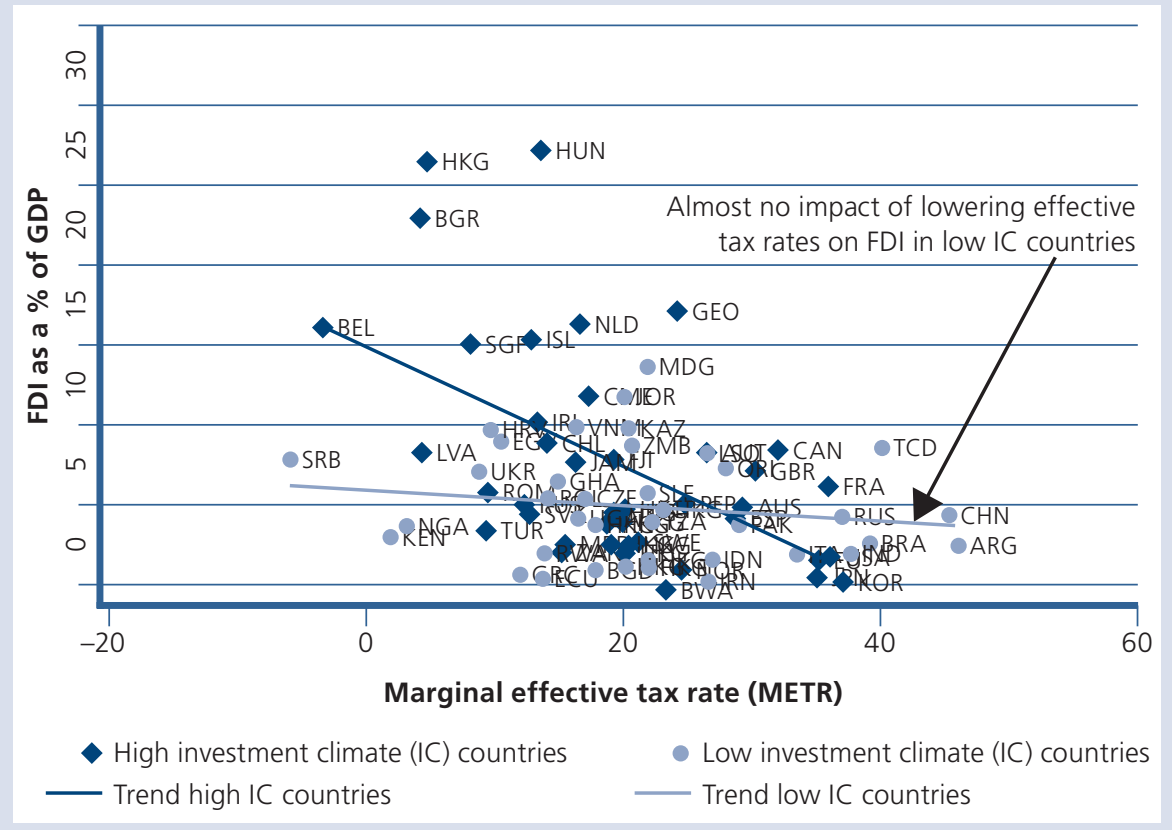

The figure above shows that for countries with a poor investment climate, ${ }^{4}$ lowering the marginal effective tax rates (METR) has very limited impact on FDI. The investment climate is measured by indicators such as ease of starting a business, dealing with licenses, employing workers, registering property, getting credit, protecting investors, paying taxes, trading across borders, enforcing contracts, and closing a business. The lighter line-the average response for low investmentclimate countries-is much flatter than for countries with a better investment climate. For example, lowering METR from $40 \%$ to $20 \%$ raises FDI as a $\%$ of GDP on average by $1 \%$ for the countries belonging to the bottom half in terms of investment climate; the same for the top half is eight times greater.

This is a possible explanation why some countries do much better than others in using their fiscal policy to attract investment. Hence, for countries with a poor investment climate, lowering taxes as a means of attracting investment is not likely to be very effective. The evidence shows that lower taxes do not compensate for a poor investment climate, rather, in order to attract investment, countries should first improve their investment climate.

\footnotetext{
${ }^{4}$ Countries were ranked on their investment climate using the Doing Business Ranking for 2008.
} 
- Investment incentives do not work for many firms as they face finance constraints, and cannot grow to take advantage of the tax incentives.

- Because the supply of capital goods is inelastic in the short run, some investment incentives might be captured by suppliers of the capital goods and not benefit the investor at all.

- Low inflation, which is a result of factors other than a policy decision to award incentives, works as a very good investment subsidy.

- Temporary incentives can have larger short-run impact than permanent incentives.

More recent studies (Desai, Foley and Hines (2006) on investment of US multinational corporations (MNCs) and their sensitivity to host country's tax rates found that US MNCs in countries with 10\% higher indirect tax rate have $7.1 \%$ fewer assets (physical investments). Further, in countries with 10\% higher corporate income tax rate, they have $6.6 \%$ fewer assets.

While Hasset and Hubbard (2002) find little evidence of tax policy impact on overall investment using macroeconomic data, there is, however, evidence that taxes affect the volume and location of foreign direct investment (FDI). De Mooij and Ederven (2003) concluded that the literature reflects that on average a $1 \%$ point increase in the tax rate reduced FDI by 3.3\%. However, the effectiveness of fiscal policy in improving investment depends on the investment climate. In countries with a poor investment climate, taxes have little impact on FDI, while it has much greater effect in countries where the investment climate is conducive (see box 7.1 above).

\subsection{Policy Rationale for Tax Incentives}

When stimulating certain economic activities or sectors, or when establishing its policy to attract investment, a government should always ask what policy decision is likely to generate the most economic activity or growth in the long run: spending a dollar directly on infrastructure/ public services or spending a dollar through tax expenditure.

The answer depends on the level of public goods and services that is already present in the country. The lower the level of infrastructure and public services in a country, the higher the productivity of one dollar spent directly on infrastructure or services as compared to the productivity of one dollar spent on tax concessions.

- Example 1: Tourism: In a country with very poor road infrastructure, one dollar spent on road infrastructure to a tourist area can create more economic activity than a one dollar tax concession to a tourism firm.

- Example 2: Manufacturing: In a country with poor infrastructure and low skilled labor, one dollar spent on road or port infrastructure/telecom/ education would attract more companies than one dollar of tax concessions to a manufacturing firm. 
It should be noted also that investors trade-off the benefit of a dollar in tax concession against the dollar in public goods and services it would benefit from when paying an extra dollar on tax. However, a dollar spent as a tax concession only benefits one investor, while a dollar directly spent on infrastructure benefits multiple investors.

If a government decides to grant tax concessions (evidence confirms that direct spending would be more productive) it should do it only for one of the following economic reasons:

1. Stimulate investments or economic activity that has positive spillovers to the rest of the economy, for example:

- Investment in R\&D

- Environmental friendly technology

- Large infrastructure projects

- Investment that creates jobs in an area suffering from serious unemployment

- Investment that upgrades workers' skills.

2. International tax competition: by offering incentives, countries are sometimes effective in attracting investment that would otherwise not have taken place in this country. Tax competition, on the other hand, creates a "race to the bottom" with countries out-competing each other in offering incentives. There is evidence that countries who win investments can suffer from the "winner's curse," having given up too much in the process. In general, mobile investments that respond to tax incentives often relocate to another tax-favored jurisdiction when the incentives are exhausted-see Bolnick (2004).

- Example 1: An international textile company (these are highly mobile in general) looking for the country where exporting its good would cost least. An effective use of tax incentives could tax concessions only for the exports of the company.

- Example 2: Mining companies are not mobile-they need the natural resources that are present in the country. Even though they, like textile firms, export their product, they should not be given tax exemptions since they are unlikely to move operations out of the country.

A recent empirical study by the World Bank/IFC shows that income tax exemptions in the WAEMU and CEMAC countries were not effective in attracting investment. Over the period 1994-2006, all changes in tax incentives were tracked for these 12 western African countries. The study found that granting general exemptions did not have a significant effect on Foreign Direct Investment. In only a few cases, tax incentives focused on exporting firms had a small positive impact on FDI. The study shows, however, that reducing the complexity of the tax regime and granting more legal guarantees 
to foreign investors had a positive impact on investment. Investors highly value transparency, predictability, and enforceability in the tax system. Legal guarantees such as national treatment guarantee, guarantees against expropriation, guarantees to protect intellectual property and allow capital/profit repatriation, and guarantee of access to international dispute settlement are also key concerns for investors. (See Box 7.2.)

BOX 7.2 Incentives and Investment in the UMEOA-CEMAC Countries

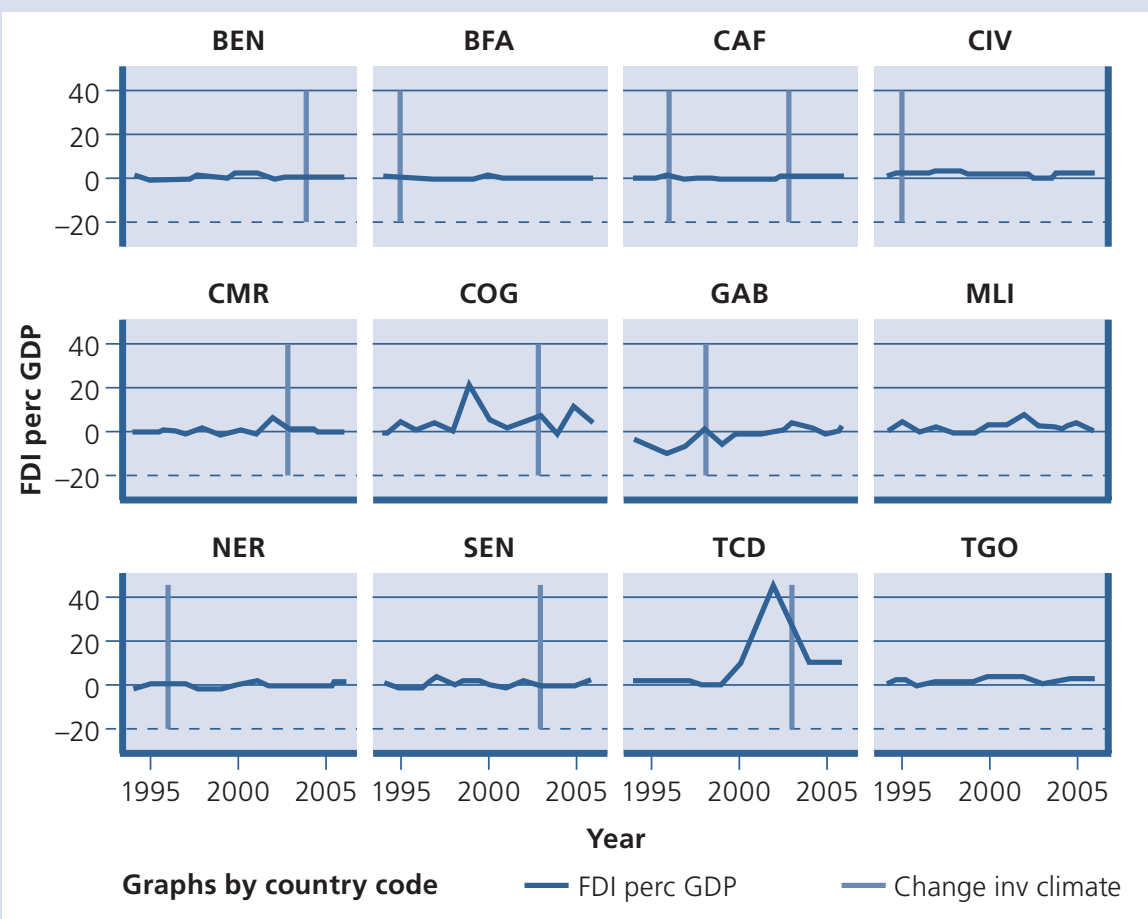

The [Franc des Colonies] CFA Franc Zone consists of the eight WAEMU (West African Economic and Monetary Union) countries and the six CEMAC (Communaute Economique et Monetaire de I'Afrique Centrale) countries. Since these countries are relatively homogenous-they share the same currency (the CFA franc), speak the same language (French), and are geographically close to each other-they constitute a unique basis for comparison of investment and policies. In a study that investigates whether changes in the fiscal IC in these countries between 1994 and 2006 were effective in attracting FDI, the authors found that tax incentives had no discernible effect on the investment, as shown in the figure. The vertical line denotes the introduction of a new investment code which includes various investor-friendly changes such as tax incentives and legal protection/ guarantees to investors. The study finds that increasing the generosity of the tax incentives does not have any effect on FDI. However, a reduction in the number of different incentives regimes as well as increasing the number of guarantees for investors have a positive impact on FDI.

Source: James and Van Parys, World Bank 2009. 


\subsection{Types of Tax Incentives and Their Relative Value}

Various international institutions including World Bank teams have made several evidence-based observations from their experiences in evaluating fiscal incentives around the world.

The following highlights important considerations for governments when evaluating implementation of various fiscal incentives.

\subsubsection{Tax holidays}

Tax holidays provide a tax incentive that completely or partially exempts all income from taxation for a specified number of years. This is a very popular, though ineffective, form of incentive because:

- It does not explicitly target capital investment. Tax holidays are a blanket benefit given to investors and are not related to the amount of capital invested or even the growth in investment during the period of the tax

\section{Typical Tax Incentives}

Tax holidays: Temporary exemption of a new firm or investment from certain specified taxes, typically at least corporate income tax. Sometimes administrative requirements are also waived, notably the need to file tax returns. Partial tax holidays offer reduced obligations rather than full exemption.

Special zones: Geographically limited areas in which qualified firms can locate and thus benefit from exemption of varying scope from taxes and/or administrative requirements. Zones are often aimed at exporters and located close to a port. In some countries, however, qualifying companies can be declared "zones" irrespective of their location.

Investment tax credit: Deduction of a certain fraction of an investment from the tax liability. Rules differ regarding excess credits (credits in excess of tax liability) and include the possibility that they may be lost, carried forward, or refunded.

Investment allowance: Deduction of a certain fraction of an investment from taxable profits (in addition to depreciation). The value of an allowance is the product of the allowance and the tax rate. Unlike a tax credit, its value will thus vary across firms unless there is a single tax rate. Moreover, the value is affected by changes to the tax rate, with a tax cut reducing it.

Accelerated depreciation: Depreciation at a faster schedule than available to the rest of the economy. This can be implemented in many ways, including higher first-year depreciation allowances or increased depreciation rates. Tax payments in nominal terms are unaffected, but their net present value is reduced and the liquidity of firms is improved.

Reduced tax rates: Reduction in a tax rate, typically the corporate income tax rate.

Exemptions from various taxes: Exemption from certain taxes, often those collected at the border, such as tariffs, excises, and VAT on imported inputs.

Financing incentives: Reductions in tax rates applying to providers of funds, for example, reduced withholding taxes on dividends.

Source: Causes, Benefits, and Risks of Business Tax Incentives. Alexander Klemm, IMF (2009). 
holiday. These could be linked together when, for example, there are minimum capital investment requirements to get the benefit of the tax holiday.

- Firms have an incentive to close down and sell their business at the end of the tax holiday, only to then reopen as a "new" investment, thus gaining an indefinite tax holiday.

- With foreign direct investment (FDI) operating under double taxation agreements, in the absence of tax sparing, tax holidays simply lead to a transfer of tax revenues from the country receiving the investments to the investing home country.

- Tax holidays threaten the existing tax base by allowing firms to funnel profits, via transfer pricing, from an existing profitable company through the "tax holiday" company and therefore avoid paying taxes on either.

- Most capital-intensive investments do not yield a profit until several years after operations have begun. Therefore, tax holidays for a "start-up" period of (say) 5 years are ineffective; and, in fact, tax liabilities kick in just about when a business starts to make a profit.

\subsubsection{Performance-based incentives}

Incentives such as investment allowances, investment tax credits, and accelerated depreciation reduce taxable income, depending on the size of the investment. They help businesses by moving the tax liability to later years, hence providing benefit by reducing the present value of taxes paid. With each of these tools, the incentive is specifically targeted to the capital investment; hence, they are all superior instruments or "smart" incentives. As a result, the cost-benefit ratio (in terms of additional investment generated per unit of revenue lost) is high. Table 7.1 shows that the investment tax credit is the most cost-effective and long tax holidays are the least effective incentives to drive investment.

A popular performance-based incentive is the "number of jobs created" by the investment. The disadvantage of this measure is that it is difficult to administer, especially if the business employs workers who are not likely to pay taxes (especially payroll taxes) and if the labor regulations in the country are weak.

As a corollary to the last bullet point in the previous section, an investmentlinked incentive could be packaged as a tax holiday, if the government finds it more attractive to market it that way. This would require specifying a minimum threshold for investment to qualify for a tax holiday up to a certain period. By choosing a minimum threshold sufficiently high, an investment-linked incentive, such as an accelerated depreciation, would have reduced taxable income to zero for the same number of years as the tax holiday. In such a case, the tax holiday combined with the minimum threshold works in the same manner as an investment-linked incentive. 
TABLE 7.1 Cost-effectiveness of tax incentives ${ }^{5}$

\begin{tabular}{|c|c|c|c|c|}
\hline \multirow[b]{2}{*}{$\begin{array}{l}\text { Relative cost-effectiveness ratios } \\
\text { for various tax incentives }{ }^{\mathrm{a}}\end{array}$} & \multicolumn{4}{|c|}{ Scenarios } \\
\hline & $\begin{array}{c}1 \\
0 \% \text { debt; } \\
\text { greenfield } \\
\text { project }^{c}\end{array}$ & $\begin{array}{c}2 \\
\mathbf{5 0 \%} \text { debt; } \\
\text { greenfield } \\
\text { project }^{c}\end{array}$ & $\begin{array}{c}3 \\
0 \% \text { debt; } \\
100 \% \\
\text { plant and } \\
\text { equipment }\end{array}$ & $\begin{array}{c}4 \\
50 \% \text { debt; } \\
100 \% \\
\text { plant and } \\
\text { equipment }\end{array}$ \\
\hline METR for benchmark tax regime ${ }^{b}$ & $57.0 \%$ & $52.6 \%$ & $59.0 \%$ & $56.0 \%$ \\
\hline 1 Benchmark + Tax rate $=30 \%^{d}$ & 1.01 & 1.00 & 1.02 & 0.98 \\
\hline 2 Benchmark + Tax rate $=15 \%^{d}$ & 0.99 & 0.92 & 0.98 & 0.90 \\
\hline 3 Benchmark + Tax holiday of 5 years & 1.07 & 1.12 & 1.05 & 1.07 \\
\hline 4 Benchmark + Tax holiday of 10 years & 0.96 & 0.88 & 0.95 & 0.85 \\
\hline $\begin{array}{l}5 \text { Benchmark + Double declining } \\
\text { balance }\end{array}$ & 1.03 & 1.30 & 1.03 & 1.21 \\
\hline $\begin{array}{l}6 \text { Benchmark }+20 \% \text { ITC } \\
\text { (no adjustment to basis) }^{\text {e }}\end{array}$ & 1.43 & 1.72 & 1.51 & 1.81 \\
\hline $\begin{array}{l}7 \text { Benchmark + 50\% IA } \\
\text { (adjustment to basis) }^{\mathrm{e}}\end{array}$ & 1.06 & 1.30 & 1.04 & 1.21 \\
\hline $\begin{array}{l}8 \text { Benchmark }+50 \% \text { IA } \\
\text { (no adjustment to basis) }^{\text {e }}\end{array}$ & 1.05 & 1.07 & 1.03 & 0.96 \\
\hline 9 Benchmark + Dividend tax $=0 \%$ & 1.02 & 1.07 & 1.02 & 1.05 \\
\hline 10 Benchmark + Capital gains tax $=0 \%$ & 1.00 & 0.81 & 1.01 & 0.84 \\
\hline $\begin{array}{l}11 \text { Benchmark + Import duty on } \\
\text { capital goods }=0 \%\end{array}$ & 1.03 & 1.22 & 1.03 & 1.21 \\
\hline
\end{tabular}

Source: Bolnick (2004).

Notes:

a. Relative cost-effectiveness $(R C E)=$ percentage decline in METR/percentage decline in PV Tax. When RCE > 1, then the incentive effect (\% reduction in METR) exceeds the direct revenue effect (\% forgone revenue, in present value terms).

b. Benchmark case: $35 \%$ company tax and capital gains tax; declining balance depreciation at rates of 5\%, 15\%, 25\% for buildings, plant and equipment, and vehicles, respectively; $15 \%$ dividend withholding tax; unlimited loss carryforward, but no loss offset; $10 \%$ inflation, $25 \%$ nominal interest rate (to accentuate debt effect), without indexing; $10 \%$ duty on imported capital goods; sale of company after 10 years.

c. Greenfield project $=10 \%$ land, $40 \%$ building; $40 \%$ plant and equipment; $10 \%$ vehicles

d. Capital Gains Rate also adjusted to equal to the tax rate.

e. ITC = investment tax credit; IA = initial allowance.

\subsubsection{Export-based incentives target those who primarily export their production}

As discussed above, an exporter is especially price-sensitive and, hence, any reduction in the cost of business, including taxes, could be passed on in the form of lower prices that help the firm remain competitive in the international market. However, tax 
is only one of the several "costs" for the business. It is not clear in all cases that the cost in terms of lost revenue is made up by benefits that the investment brings with it. Export-linked incentives may run afoul of WTO guidelines that prohibit the use of any export subsidies. However, their use has been allowed during a grace period in some countries.

\subsubsection{Regional/subnational incentives}

Many developing countries provide for a lower income tax rate in certain disadvantaged geographic areas. Investing firms are very astute at taking advantage of such schemes, for example, by registering the company in a disadvantaged area (to take advantage of tax incentives) only to undertake the majority of operations in a high-income area. Care must be taken to guard against this. Promoting regional development can often be better undertaken through addressing the investment climate constraints in the region itself (for example, by improving infrastructure, tackling administrative barriers, subnational taxation, and regulations faced by investors). As in the case of India, there is no evidence that tax holidays for the industrially undeveloped areas, such as the northeast of that country, have resulted in additional investments in the region. On the other hand, it has been found that tax holidays for investment in industrially backward states such as Himachal Pradesh have resulted only in attracting investments meant for the neighboring state of Punjab. Further, the investments in Himachal Pradesh have not been made in the industrially backward regions of the state, but in those areas that did not disadvantage investors.

The conclusion that may be drawn is that tax incentives are not a panacea for attracting investments. Improving the overall investment climate by improving infrastructure, imposing a rule of law, strengthening institutions-including the TA-go a long way in attracting investments. The argument that tax incentives provide a signaling device to potential investors is possibly correct only when other factors provide the necessary environment for an investment to be profitable.

\subsection{The Efficacy of Tax Incentives in Developing Countries ${ }^{6}$}

Experience and analysis show that tax incentives do not play as important a role in the investment decisions of either domestic or foreign investors as certainty regarding tax and other matters, such as political stability, rule of law, and security. (See table 7.2 below on a recent survey conducted on the investor motivation.)

Tax incentives create an advantage for some firms, so they must also, by definition, create a disadvantage for others. The uneven playing field results in increasing demands

\footnotetext{
6 This section draws heavily on Zee and others (2002), Bolnick (2004), and Shah (ed. 1995).
} 
TABLE 7.2 Investor motivation to invest and tax incentives

\begin{tabular}{|c|c|c|c|}
\hline & Mozambique $(60)^{*}$ & Jordan (61) & Serbia (50) \\
\hline $\begin{array}{l}\text { Three most } \\
\text { critical factors } \\
\text { for investment } \\
\text { decision }\end{array}$ & $\begin{array}{l}\text { 1. Domestic market } \\
(38)^{\star *} \\
\text { 2. Little competition } \\
\text { (16) } \\
\text { 3. Political stability (14) }\end{array}$ & $\begin{array}{l}\text { 1. Investment climate } \\
\text { related }{ }^{* *}(31) \\
\text { 1. Political stability and } \\
\text { security (25) } \\
\text { 1. Local market (23) }\end{array}$ & $\begin{array}{l}\text { 1. Investment climate } \\
\text { related (37) } \\
\text { 1. Skilled and } \\
\text { competitively priced } \\
\text { labor ( } 33 \text { ) } \\
\text { 2. Personal reasons (18) }\end{array}$ \\
\hline $\begin{array}{l}\text { How did tax } \\
\text { incentives rank? }\end{array}$ & $\begin{array}{l}2 \% \text { mentioned tax } \\
\text { incentives as a critical } \\
\text { factor }\end{array}$ & $\begin{array}{l}15 \% \text { mentioned tax } \\
\text { incentives as a critical } \\
\text { factor }\end{array}$ & $\begin{array}{l}12 \% \text { mentioned tax } \\
\text { incentives as a critical } \\
\text { factor }\end{array}$ \\
\hline
\end{tabular}

*Number of investors surveyed in brackets; ** Number of investors who mentioned the factor as critical in brackets; $* * *$ Includes ease of import and export, availability of local suppliers, regulatory framework, adequate infrastructure; geographic position of the country; good infrastructure.

Source: Investment Climate Advisory (2009).

for incentives in all sectors and for new incentives to replace old ones. The result is most commonly a complex web of incentives that are difficult to understand for the investor, difficult to administer, and provide little real benefit.

Several countries have used tax incentives in hopes of attracting investment. The results have shown that even when they appear to have worked, they do so only when accompanied by other factors such as a stable macroeconomy, tight fiscal and monetary policy, and a proactive government that went out of its way to woo investors.

In fact, several countries have stopped giving tax holidays and have replaced them with a uniform regime of low tax rates and highly selective and limited tax incentives. South Africa replaced tax holidays with duty-free imports, higher capital allowances, zero-rating of VAT for exports, and so forth. In 1997, Uganda replaced tax holidays with a lower uniform corporate tax rate and still attracted large increases in foreign investment. In 1984, Indonesia lowered the corporate tax rate from 45 percent to 35 percent and removed all selective tax incentives such as tax holidays, preferential tax rates, and accelerated depreciation. FDI went up many times over the next decade. More recently, in 2005, Egypt replaced all its tax incentives with a lower tax on profit to a uniform rate of 20 percent. Tax revenues increased from 4 percent to 7 percent of gross domestic product (GDP) in one year.

Tax incentives have worked, but only when the broader macroeconomy provided a catalyst. Ireland began providing tax incentives in 1959 that included tax holidays and export profits being entirely tax free. This did little for investment growth. In 1981 the tax holidays were replaced by a uniform, very low tax rate of 10 percent combined with major reforms including a tight new monetary and fiscal 
policy. In the case of Costa Rica, export promotion programs that included EPZs and investment incentives failed to benefit the country until the mid-1980s, when exports rose rapidly as the country's economy stabilized, the currency was devalued, and the highly bureaucratic EPZ laws were relaxed.

Finally, even when tax incentives have been successful in attracting foreign investment, it has not been without cost, which in some cases has been more than the benefit. Malaysia, which used tax holidays and EPZs with zero import duties and subsidized infrastructure since 1958, did attract large amounts of investment. However, the World Investment Report 2002 mentions that the forgone revenue was as high as 1.7 percent of GDP and that some of the incentives were overly generous (Bolnick 2004).

\subsection{Institutional Framework and Political Economy Issues of Tax Incentives}

Political economy considerations are very important when designing a policy on tax incentives. Some of the reasons why tax incentives proliferate are:

- They are a less visible means for governments to provide special benefits to certain businesses.

- When ministries other than the ministry of finance (MoF) are allowed to give out tax incentives, the incentives are misaligned. Non-MoF ministries tend to give out more incentives than what is optimal, as they do not have to bear the burden of lower tax collection, which is the job of the MoF.

- Governments want to be seen to be doing something proactive to attract investments. The easiest approach tends to be to give up revenue that they do not have.

Tax incentives, like any other market intervention, are justified if they correct market inefficiencies or generate positive externalities. There is limited evidence that tax concessions work; but their appeal to politicians is considerable since discretionary tax incentives, especially in developing countries, allow political influence over policy options, provide the political appearance of action, and also facilitate political and administrative corruption.

Tax expenditures (incentives, concessions, holidays, exemptions) are of especially politically attractive as the cost is usually unknown, interference from other "veto players" like legislatures is limited or nonexistent, and the loss of revenue is dispersed over the long-term, while the political benefits, especially in discretionary regimes, are immediate and offer opportunities for corruption, on which political stability (Khan 2006) and personal greed depend. Tax incentives (and corruption around them) therefore offer what Douglass North et al (2007) describe as "the 
universal problem of violence and disorder" by giving individuals and groups incentives to cooperate with those in power rather than fight them. ${ }^{7}$

Tax complexity results from political trade-offs, the product of elite bargaining within the political "rules of the game." For example, through the fragmented power structures under Yeltsin's Russia of the 1990s, politically powerful elites secured tax expenditure exemptions on an extraordinary scale, estimated at more than twothirds of total taxes collected for the federal budget. ${ }^{8}$

In Yemen, while the corporate income tax headline rate is 35 percent, the incentive regime reduces the average effective rate to about 15-20 percent. Corruption reduces the tax burden: while the typical bribe ranges from 25 to 40 percent of the total assessed tax amount, paying the bribe can lower the tax assessment by 50 percent, so that even many large firms file their informally negotiated tax amount under the presumptive regime?

Tax incentives have worked in the context of effective governance. In east Asia, governments were able to offer successful nondiscretionary incentives to attract private investors, export promotion, and stimulate technological adaptation and innovation (Choi and Kwack 1990). The type of political regime influences tax incentive policy. Countries with better governance offer fewer tax incentives, and the effect is greater in more democratic countries (Li 2006). In weaker governance environments without the political incentive to deliver economic growth to legitimize the state, it can be difficult for political processes to select appropriate projects to support. Equally, tax incentives may shift investment to industries or areas of political priority because of redistributive concerns (for example, incentives for investment in poor areas), positive spillovers (for example, incentives for high-tech industries that transfer technology to the rest of the economy), or for economic diversification. But in all cases, it remains problematic for political processes to correctly identify such spillovers without the politically driven "action learning" that underpinned the East Asian miracle.

Opinion is sharply divided on whether fiscal incentives increase investment and create jobs and other socioeconomic benefits (for example, Bora 2002; Blomstrom and Kokko 2003) — or are ineffectual, with the costs of incentives to attract FDI outweighing the benefits by exacerbating poor governance and corruption (for example, Halvorsen 1995; Wilson 1996; Osman 2000; Wells and others 2001). The balance of evidence suggests that, in many developing countries, fiscal incentives do not effectively counter-balance wider problems such as poor infrastructure, weak governance, and macroeconomic instability. As a result, the effect of poorly performing countries offering too many concessions is an adverse effect on FDI inflow.

\footnotetext{
7 Limited Access Orders in the Third World: A New Approach to the Problems of Development: NBER.

8 Easter (2008).

9 FIAS study April 2007.
} 
One reason for such countries' poor performance is corruption. South Africa, Mauritius, and Botswana have low levels of corruption and attract high rates of FDI. (Highly corrupt countries, according to the Transparency International [TI] index, also attract large amounts of FDI- for example, Nigeria-because of the influence of other factors like market size, growth, and natural resources.) As Bowles has noted: "In many cases, political corruption is, at least, as serious an issue as corruption of the tax bureaucracy. Low salaries for tax officials, political protection of prominent tax evaders, poor monitoring of junior officials, high tax rates, high levels of discretion for the tax officials, and poor information generally are some of the reasons commentators are inclined to give for the persistence of extensive corruption in many countries in Africa, Asia, and Latin America" (Bowles 1998). For example, Transparency International (TI), in a study of 21 cities in Indonesia in 2004, found that the prevalence of corrupt behavior, such as tax officials helping taxpayers' fraud practices, had an impact on tax revenue collected by the state. In Uganda, efforts to stamp out corruption have had limited effect. Fjeldstad and others (2003) traced the prevalence of corruption at the managerial level in the Uganda Revenue Authority (URA) to politics. Although asset declaration was introduced in 2002 for all URA staff, the lack of political will to implement anticorruption effectively has led to very limited results, and when a Commission of Inquiry on Corruption in the URA appointed in the same year produced a much-delayed and debated report two years later, its legality was questioned by members of parliament (MPs) and ultimately nullified by the high court. The URA offers well-paid jobs, relatively good working conditions, and rent-seeking opportunities, making it an attractive target for political interference in its recruitment and dismissal practices, and its operations generally. Political interference featured in the local media further undermined the reputation of the URA. In 2003, for example, five senior officers attached to large taxpayer units (LTUs) were involved in a major corruption scandal. ${ }^{10}$ Traditional networks of kinships or community origin also appear to be prevalent and tolerated within the URA. Strong political determination as well as broad policy and administrative reforms are needed to tackle the many causes of corrupt practices, including around tax incentives. ${ }^{11}$

\subsection{Managing and Administering Tax Incentives}

When a government decides that for various reasons it needs to provide Tax Incentives, there is a policy spectrum with several options for positioning itself. Table 7.3 below shows the various options from a common tax policy applied to all taxpayers (for example, a low tax rate with a broad base) on one side to a liberal incentives policy at the other.

\footnotetext{
${ }^{10}$ See Fjeldstad and others (2003) on Tanzania.

${ }^{11}$ See Stotsky and WoldeMariam (2002) for Central America and Stotsky and WoldeMariam (1997) for Sub-Saharan Africa.
} 
TABLE 7.3 Tax incentive policy options for government

\begin{tabular}{|l|l|l}
\hline & Policy Toward Tax Incentives & Remarks \\
\cline { 2 - 3 } & No incentives & Same tax regime for all \\
\hline & $\begin{array}{l}\text { Incentives only for marginal } \\
\text { investments (e.g., export) }\end{array}$ & $\begin{array}{l}\text { Those investments that are very likely to go } \\
\text { elsewhere ("footloose" investments) }\end{array}$ \\
\hline & Incentives, but only investment-linked & $\begin{array}{l}\text { Accelerated depreciation, investment } \\
\text { allowances, etc. }\end{array}$ \\
\hline & $\begin{array}{l}\text { Tax holidays, but partial tax holidays } \\
\text { (50\% tax reduction) }\end{array}$ & $\begin{array}{l}\text { Provides tax holidays but gets at least some } \\
\text { tax revenue for government }\end{array}$ \\
\hline $\begin{array}{ll}\text { All tax incentives, but with yearly tax } \\
\text { expenditure statements }\end{array}$ & $\begin{array}{l}\text { Provides transparency on the cost of the } \\
\text { incentives }\end{array}$ \\
\hline All tax incentives & Could be costly for the government
\end{tabular}

As mentioned above, tax incentives create an uneven playing field and, as a result, present opportunities for rent seeking. Where tax holidays do exist, therefore, specific policies are required in order to mitigate the problems associated with them.

\subsubsection{Granting of incentives-transparent and automatic}

Granting an investment incentive has to be done according to a set of predetermined and uniform criteria that the public is privy to, and information on the incentive has to be open to public scrutiny. To this end, differentiating between domestic and foreign investors in granting incentives is undesirable-it distorts the business environment and signals an uneven playing field. Further, tax incentives should be provided only by law and approved by the legislature. This is particularly relevant because budgetary processes are usually subject to parliamentary oversight, and as tax incentives have budgetary consequences, they should be provided in a similar manner.

As mentioned in section 7.3 above, when ministries granting the tax incentives are not responsible for the collection of taxes, this could result in too many incentives being given. Eligibility for tax incentives should be provided through a (tax) law that is based on clearly declared criteria and not through special permission, certification, and so on by government agencies such as investment promotion authorities, ministry of trade, and the like. This ensures the prompt decision-making and quick turnaround times essential to attract and retain investors.

\subsubsection{Tax incentives should remain in the tax laws}

Governments should place tax incentives in the relevant tax code to enable the tax authorities to administer them. TAs are best able to administer tax incentives on a regular basis. In some cases, tax incentives are provided in different statutes, and in 
some extreme cases, in individual agreements with investors. This causes confusion as to which government body would administer the incentives. If the relevant tax clauses cannot be moved and placed in the tax law at the very least, the various tax incentives should be mirrored or copied into the tax law. This unambiguously allows the tax administration to then administer them.

It is necessary that the tax administration check that investors taking advantage of the tax incentives satisfy the specific eligibility requirements laid down for them. To enable them to do so, it should be made compulsory that tax returns, tax declarations, and all relevant tax forms be filed on a regular basis as a precondition to benefiting from the incentives. Tax incentives should not be used as an excuse to avoid the compliance requirements of the tax administration.

\subsubsection{Continuous review of tax incentives}

Investment incentives should be regularly reviewed to ensure relevance and effectiveness. The government should undertake periodic analysis of their costs and benefits. It would be useful therefore for the government to develop a mechanism that provides periodic evaluation of any incentive-based investment-attraction strategy's relevance, appropriateness, and economic benefits against their budgetary and other costs, including long-term impacts on resource allocation. The incorporation of the details of ever-changing incentives in investment laws compromises the certainty that investors expect. (Section 7.7 discusses this in greater detail.)

\subsubsection{Tackling the duration of tax holidays}

Tax holidays create a community of businesses that depend on them-and lobby for their continuance even after their benefits have terminated. In many countries, tax holidays tend to remain on the statute books well beyond the period they were originally intended for and well after the benefit from such a policy no longer exists. Further, it has been seen that businesses that claimed the tax holiday for the eligible number of years reorganize and resurface-by another name and in another place-to continue to take advantage of benefits. It must generally be borne in mind that tax holidays create many opportunities for leakage.

\subsubsection{Tackling transfer pricing}

The broader concept of transfer pricing applies to the pricing of transactions (for services, goods, capital assets, interest, intangibles, salaries, and so on) among related entities within a corporate group across jurisdictions. Since the pricing for these intragroup transactions is not established by the market, there is potential for multinational businesses to set prices to allow profits to be shifted from a higher to a lower tax jurisdiction, reducing the corporate group's total tax. This has led to an increase 
in the enactment and enforcement of transfer pricing regulations that attempt to compel corporations to follow accepted transfer pricing methodologies designed to ensure that intragroup pricing follows arm's length principles. Particular emphasis is placed on the documentation of pricing decisions to allow tax authorities to review and enforce transfer pricing more easily.

The above noted transfer pricing challenges would also apply in the context of tax holidays, given that there is a lower-taxed entity (subject to a tax holiday) and a higher-taxed entity, albeit in the same jurisdiction.

7.6.5.1 Helping tax authorities tackle transfer pricing. Tackling transfer pricing is typically very difficult for any tax authority. The following methods help to improve a tax authority's administrative capacity by providing it with additional information for better assessments of tax avoidance and evasion (James 2007). Such methods include requirements that:

- All businesses enjoying tax holidays must file income tax returns. If the tax holiday tenant is part of another taxed entity, it must file separate financial statements of its activities along with the tax return.

- All businesses enjoying tax holidays must reveal in their tax return the units and/or firms that are owned by related individuals or related businesses.

- Transfer pricing compliance requirements for international firms must be imposed for such related businesses.

- An audit strategy must be in place to identify cases that report "higher than usual" profits for units enjoying tax holidays and "lower than usual" profits for related units not having tax holidays. It is also possible that profit diversion is sold for a fee to unrelated parties; but this should be reflected in "higher than usual" profits for units enjoying tax holidays. There is no foolproof method to identify all cases, but such unusual profit figures could act as audit triggers.

\subsubsection{Controlling abuse of tax holidays}

As mentioned, there is a strong motivation for firms to reorganize themselves to extend their claim to tax benefits. Another potential problem for tax authorities arises when a firm ineligible for a tax holiday scheme reorganizes as a new firm to avail itself of the benefits. This runs counter to the intended goal, with the added risk of reducing the existing tax base.

It is recommended that the process of approving companies for tax holidays be tightly controlled. Strict information requirements (including complete financial statements of related businesses) must be imposed on firms seeking these benefits. This ensures that activities that deplete investment or retained earnings in one unit, 
with corresponding increase in the other, can be tracked during audit. Such unusual depletion could then trigger an audit. However, this does not solve the problem of units that do not benefit from the tax holiday to license out their production to firms that do benefit from them-which is legal. Such possibilities are reduced when there is adequate demand for the goods produced and that businesses would not find it beneficial to produce below their capacity.

\subsubsection{Increasing Transparency of the Costs and Benefits of Tax Incentives}

Tax incentives have costs that can be measured relatively easily but benefits that are uncertain. It would greatly benefit policy makers to inform the public and legislatures of these costs and benefits so that these incentives can be reevaluated from time to time. Tax expenditure statements are, internationally, the best practice; they greatly increase transparency, and raise the level of debate on the relevance of these incentives.

A good practice is to include a provision that places the benefits and costs of the tax incentives before the legislature on a yearly basis. This would be possible with a yearly tax expenditure statement that includes the incentives accorded under tax laws.

\subsection{Revenue Cost of Tax Incentives-Tax Expenditures ${ }^{12}$}

For the sake of stability in public finance and for ensuring the revenue stream projected by the MoF, tax incentives need to budgeted like any other direct expenditure. In this respect tax incentives are sometimes referred to as tax expenditures.

While the main purpose of the tax system is to raise revenue to finance public goods, governments frequently use it to pursue other goals such as encouraging certain economic activities. A good example is the tax deduction given to individuals for payment of mortgage interest, which has the effect of lowering the cost of owning a house; however, this results in lower government revenue. Tax incentives given to businesses also encourage certain kind of business activities that have revenue costs. However, unlike direct expenditures made out of the budget, such tax costs are generally not perceived by the public as expenditures, though they have the same effect. Such tax costs are expenditures if one views it as if the taxes are collected as usual and then given (spent) directly on those taxpayers who have taken advantage of the tax concessions. Tax expenditures in some cases are equivalent to fiscal transfers from the central/federal government to lower levels of government if, for example, tax benefits are given to invest in local government bonds, or when taxes paid to the local governments are deductible when calculating the taxable income paid to the central government.

${ }^{12}$ A major part of this section was drawn from Brixi and others (2003). 


\subsubsection{Definition of tax expenditures}

Tax expenditures are defined as revenue losses that arise due to concessions that fall outside the regular tax system. Such concessions can take the form of special deductions from revenue to calculate profits, lower rates of direct or indirect taxes, exemption from taxation, and so on. Tax concessions could also be in the form of tax deferrals such as accelerated depreciation given to certain investments. Examples of tax expenditures include:

- Exemptions: income excluded from the tax base

- Allowances: amounts deducted from gross taxable income

- Credits: amounts deducted from tax liability

- Rate relief: a reduced rate of tax applied to a class of taxpayers or activities

- Tax deferrals: relief that takes the form of delay in paying tax (for example, accelerated depreciation)

\subsubsection{Tax expenditures v. direct expenditures}

Tax expenditures generally do not attract the same amount of scrutiny as direct expenditures. However, they may be a large part of government spending. The United States, for example, in a 2008 report by the Joint Committee on Taxation to the House and Senate, lists 234 different tax expenditures for the period 2008-12 totaling $\$ 5.6$ trillion and rivaling regular direct expenditure. Because of its importance, in the interest of transparency, several countries now publish tax expenditure budgets just as they do regular budgets; in most cases, these are presented to the public and to decision makers. The United States has been implementing these since 1968. Today tax expenditure reports are part of the regular practice in OECD countries. They are also gaining recognition in developing countries; India and Morocco have implemented them. In 2006, Morocco estimated that it incurred tax expenditures for only 159 of its 409 tax concessions, which amounted to least 17 percent of the tax revenue or 3.7 percent of GDP. ${ }^{13}$

As the definition suggests, tax expenditures result from deviations from the regular tax system-hence, what constitutes the tax norm (or what is the normal tax system) is crucial to the calculation. The definition of the tax norm may differ from country to country; however, it helps to maintain a consistent definition so that tax expenditures may be measured and comparable year on year.

It is best practice to budget the amount of revenue foregone and made available to the public, just as in the case of the expenditure budget. This will require the

\footnotetext{
${ }^{13}$ Presentation by the Morocco Government at the OECD-MENA Conference, Cairo, 2007.
} 
Ministry of Finance to make a projection of likely amount of the tax revenue to be foregone through the tax expenditures in their budget projections. This will make them accountable for monitoring the necessary conditions, as well.

Tax expenditure budgets and reports are usually produced on a yearly basis, though some countries may do so once every two years. The process of computing the tax expenditures is data-intensive and may stretch the capacity of tax policy departments. However, the benefit in terms of transparency suggests that countries benefit from these reports. Countries may or may not adopt a regular process of preparing them every year: In Australia, the United States, Germany, and France there is a legal obligation to report tax expenditures. However, in the United Kingdom, the Netherlands, and India, there is none.

\subsubsection{Tax expenditures and accountability}

By providing a greater level of transparency in how governments spend money, tax expenditure reports improve the accountability of governments to taxpayers. It is quite common in countries with weak institutions for powerful lobbies and special interests to extract tax concessions from governments the fiscal costs of which are rarely computed-or when computed, are never made public. As a result, tax collection is affected, reducing the ability of the governments to provide public goods to the citizens. When true fiscal costs are revealed, the public can decide if the tax concessions result in tangible benefits that more than make up for the revenue losses. This ensures that distortionary tax concessions are kept in check, improving the overall investment climate.

\subsubsection{How are tax expenditures computed?}

Tax expenditures are the revenue losses that arise due to concessions that fall outside the regular tax system. Such concessions can take the form of special deductions from the revenue to calculate profits, lower rates of direct or indirect taxes, exemption from taxation, and so on. Tax concessions can also be in the form of tax deferrals such as accelerated depreciation on certain investments. Calculation of Tax Expenditures would include tax lost dues to:

- Exemptions: income excluded from the tax base

- Allowances: amounts deducted from gross taxable income

- Credits: amounts deducted from tax liability

- Rate relief: a reduced rate of tax applied to a class of taxpayers or activities

- Tax deferrals: relief that takes the form of delay in paying tax (for example, accelerated depreciation) 
Tax expenditures are estimated using any of three methods:

The revenue foregone method. This is a calculation of the loss incurred by the government due to the tax concessions. It is static analysis and does not take into consideration the change in behavior of taxpayers due to the tax changes.

The revenue gain method. In this method, the revenue gain that would result from bringing the tax concessions to the regular level is calculated. In this method, behavioral changes by taxpayers are taken into consideration when computing the revenue gain. For example, if the VAT rate for a certain preferred consumption is increased to the regular VAT rate, this might result in lower level of consumption because of a higher price. As a result, the computation of the tax expenditure, in this case, would take into consideration the new demand for the goods (using the tax elasticities) and, in this case, the tax expenditure may not be as high as the case if such behavioral changes are not taken into consideration.

The outlay equivalent method. In this method, the tax expenditure is calculated as the direct spending that would provide the same benefit to the taxpayer as the tax concession. This would differ from revenue forgone if the direct spending on the taxpayer in the form of a grant, for example, which is itself taxable.

The actual calculation is data-intensive, requiring extensive details of taxpayers' accounts. It is usually done by simulating the tax concessions and the tax norms on a sample of tax returns.

The table below gives basic calculations of the most popular tax expenditures:

\begin{tabular}{ll}
\hline Tax expenditure type & Calculation \\
\hline Tax exemption (e.g., tax holiday) & $\begin{array}{l}\text { Gross income of companies that qualify for tax holiday * } \\
\text { effective tax rate } T\end{array}$ \\
\hline Investment allowances (\%) & Investment that qualifies for allowance * Allowance * $T$ \\
\hline Investment tax credit (\%) & Investment that qualifies for credit * Credit \\
\hline Reduced tax rate R & $\begin{array}{l}\text { Gross income of companies that qualify for the reduced tax } \\
\text { rate* }(T-R)\end{array}$ \\
\hline Accelerated depreciation & $\begin{array}{l}\text { Deductions for the current year-income inclusion from } \\
\text { previous deferrals for the current year }\end{array}$ \\
\hline Import tax exemptions & $\begin{array}{l}\text { Value of imports qualifying for the import tax exemption * } \\
\text { import tax }\end{array}$ \\
\hline
\end{tabular}




\subsubsection{Indirect costs of tax expenditures}

The calculation above is limited to the financial cost of tax incentives. However, there are additional costs that the businesses (and the tax administration) have to incur. Some of these costs are:

- Time and money that businesses ineligible for tax benefits spend lobbying the government to obtain such benefits

- Time and money spent by business to obtain investment certificates to qualify for the tax incentive

- Additional time spent by businesses to actually obtain the tax benefit, for example to justify the tax exemption status

- Revenue lost due to illegal activity

- Businesses that do not qualify for the exemption take advantage of the tax exemption by falsifying information

- Indirect revenue lost by businesses that do not qualify for the tax incentive in (illegally) using tax exempt entities to source their goods

- Additional costs for tax administration to administer the tax incentives.

These nonrevenue costs are much more difficult to quantify. They may be much larger than the financial costs and, when formulating an incentive policy, must always be kept in mind.

\subsection{Conclusion}

Whatever incentives a government decides to offer and however it structures them, every effort should be made to ensure that the incentives are: (i) affordable-the income forgone should not have a severe effect on government revenue streams; further, the introduction of the incentive should not jeopardize financial allocations from the government to the government agencies that administer them; (ii) targetedthere should be research to confirm that the targeted areas will benefit the country in ways that would not have been the case absent incentives; (iii) simple-incentive administration should permit easy accessibility and determination of eligibility; and (iv) subject to periodic review-investment incentives should be regularly reviewed and evaluated to determine their relevance and economic benefit against their budgetary and other costs, including long-term impacts on resource allocation.

It is necessary also to caution against discretionary incentives that could notionally result in two different investors in the same sector or type of enterprise ending up with totally different incentive packages. Beyond the real risk of enabling corruption, this type of regime is contrary to internationally accepted principles and is likely 
to destroy the confidence investors should have in governmental authorities to create an enabling environment for their businesses.

Providing tax holidays, for instance, results in risks that might have implications for the investment climate and overall compliance. It also creates incentives for lobbying and rent seeking. In light of the fact that most firms in developing countries highly distrust the tax authorities, plugging the potential leakage of tax revenue by using a set of policies that are administration-intensive is not likely to be popular. Increasing the transparency of the costs and benefits of the tax incentives would, in the long run, help in the framing of future policy. Providing a level playing field for all businesses throughout the country-in the form of a low and uniform tax rate on a broad base-is a formula that has worked in many countries.

\section{Further Guidance}

- Alexander Klemm. 2009. "Causes, Benefits, and Risks of Business Tax Incentives." IMF Working Paper.

- Hana Polackova Brixi, Christian M.A. Valenduc, and Zhicheng Li Swift, eds. 2004. Tax Expenditures-Shedding Light on Government Spending through the Tax System. The World Bank.

- Das-Gupta, Arindam, and Dilip Mookherjee. 1998. Incentives and Institutional Reform in Tax Enforcement. New Delhi: Oxford University Press. 


\section{APPENDIX 7A}

\section{Methods of Transfer Pricing}

Diversion by corporate entities of profits through transfer pricing may occur in several ways:

- Through borrowing at lower than market rates from related entities. In this method, a unit not enjoying a tax holiday borrows money at market rates for the purposes of its business and lends to a unit enjoying the tax holiday at lower than the market rates, incurring a loss on that account. This loss reduces its taxable profit (assuming the rules of that country do not impute interest income on the lender where loans are made to related entities at lower than market rates). The unit with a tax holiday, on the other hand, gets financing at lower than market rates and the group as a whole pays less tax due to the "loss" incurred by the unit not enjoying the tax holiday. Properly applied, transfer-pricing principles would normally require the entity lending the money to the unit enjoying the tax holiday to charge an interest rate higher than the rate it borrowed at, to reflect the additional risk it is bearing. This would result in income rather than a loss.

- Through sourcing inputs from related parties at higher than market rates. In the same manner, units outside the tax holiday could source inputs such as raw material to the units within the tax holiday at lower than market rates. This reduces the profits of the unit outside the tax holiday and consequently the taxes owed. Again, properly applied, transfer-pricing methodology would require a markup on the inputs to approximate the behavior of arm's length parties; this would result in an increase (not a decrease) in the profits of the unit outside the tax holiday.

- Through sales at higher than market rates between a unit inside the tax holiday to one outside it. Production by a unit inside the tax holiday could be sold to a unit outside the tax holiday at higher than market prices. This has the effect of raising profits of units inside tax holidays at the expense of those outside the tax holiday. This is not an issue if all sales are export sales, as the tax benefit is 
to a unit outside the country. However, even if some of the sales can be local sales this is a potential issue that can undermine the tax base.

- Through billing sales for the unit within the tax boliday while billing inputs to the unit outside the tax holiday. A business that has units within the tax holiday and also another outside the tax holiday could bill sales of the unit outside the tax holiday illegally to the unit within the tax holiday, lowering the taxable profit of the former.

- By diverting profit from unrelated parties for a fee. All the methods described above are in violation of sound transfer pricing principles at a minimum, and, in some instances, amount to tax evasion or fraud. Nevertheless, such manipulations can be easily carried out between related parties where the tax authority is unable to carry out enforcement. The tactics could also be carried out between parties unrelated to each other as long the spoils of the evasion are shared. In cases where the parties are unrelated, these practices are very difficult to detect: the TA would have to look at all transactions with entities with business connections, including borrowers, lenders, suppliers, and buyers. Further, the TA needs to have market information to be able to make a prima facie case for transfer-pricing manipulation.

There are, however, legal methods of diverting profits; for example, an entity outside the tax holiday could contract out its sales to a unit within the tax holiday for a fee. The fee would need to reflect the value of the sales function performed by the tax holiday company. There will be a net benefit to the business group as long as the tax holiday unit's theoretical tax on the sales profits exceeds the entity outside the tax holiday's reduced tax level because of the lower profits (from paying the sales fee). This reduces potential tax revenue by diverting economic activity to the tax-free area. As long as the unit within the tax holiday has spare capacity, this would be a potential loss of revenue without new economic activity. 



\section{Chapter 8: Corruption and Tax Simplification}

\section{CHECKLIST OF GOOD PRACTICES}

$\boldsymbol{V}$ The tax administration (TA) develops an anticorruption strategy and trains its staff to recognize and address corrupt practices

$\checkmark$ The TA, as far as possible, limits direct contact with taxpayers

$\checkmark$ The TA uses both internal and external audits for oversight of its audits

$\checkmark$ The TA has a separate vigilance department that oversees cases of complaints against its tax officials

$\checkmark$ The TA also has a tax ombudsman who is independent of the tax authority and addresses complaints of corruption against tax officials

$\checkmark$ The TA meets regularly with taxpayers and their representatives to address issues of corruption and makes systemic changes to reduce their incidence

This chapter deals with improving governance in the tax system-with the primary aim of reducing costs to the tax system associated with misgovernance and corruption. The chapter begins by examining the nature of corruption in tax administrations (TAs), followed by a review of tax simplification measures designed to minimize corruption. There is, then, a review of anticorruption strategies that can be implemented in tax systems. The discussion then turns to a review of design principles for the role of information technology (IT), internal audit and vigilance, and finally, dispute- and grievance-redressing institutions in relation to the TA. The discussion concludes with brief guidelines for the sequencing of anticorruption reforms.

\subsection{The Nature of TA Corruption}

Corruption and control of it have been discussed since as far back as Kautilya's Arthashastra, ${ }^{1}$ written around 2,000 years ago. Corruption is often defined as the abuse of

\footnotetext{
1 See Rangarajan (1992). The Arthashastra lists 40 ways in which public officials can steal government money or harass citizens.
} 
public office for private gain. Common manifestations of corruption by TA officials are bribes in cash or kind either in return for illegal favors (voluntary bribes), or for refraining to use official power to cause harm (extortion). With voluntary bribes, both the bribe giver and the TA official can benefit at the cost of the public at large. Coercive bribes benefit bribe takers at the expense of bribe givers and possibly the public. Threats of harassment generally provide the inducement to pay coercive bribes or extortion. ${ }^{2}$ Nepotism and misuse or theft of public property by officials are other common types of corruption, though these cases involve what may be termed "unilateral" instead of "collusive" corruption.

Fjeldstad (2002) provides a taxonomy of bribes found in the Tanzanian revenue administration in the mid-1990s covering both unilateral and collusive corruption. Excerpts from his classification are presented in table 8.1. The table is noteworthy for documenting some types of corruption that are not widely appreciated. This includes corruption at physical border checkposts for goods trans-shipment or imports; collusive corruption that does not necessarily involve taxpayers but, instead, other officials not in the TA; and third, official corruption in tax matters by internal auditors of the TA not necessarily involving taxpayers directly.

Other types of corruption have been identified in various other studies. DasGupta (2007), for example, discusses studies identifying various other types of corruption. Some examples of collusive corruption include government recruitment and transfers to "lucrative" positions-a type of corruption not directly involving taxpayers but certainly acting as an inducement for extracting bribes from taxpayers-and corruption in awarding public procurement or outsourcing contracts. Coercive corruption involving additional extortion includes bribes to obtain refunds and also permissions and clearances from the TA (including for the release of goods from warehouses).

In terms of payment channels for bribes, apart from direct payments to TA officials (sometimes, though not always, paid to the low-level staff members and then shared upward)_full-time middlemen ${ }^{3}$ and other intermediaries, including tax accountants and shipping agents, play important roles. ${ }^{4}$

The important points that emerge from these descriptions are (i) corruption is not a homogenous activity in TA but occurs in various ways in a variety of TA activities; (ii) parties engaged in corruption may include diverse beneficiaries including TA officials, taxpayers, and third parties; and (iii) taxpayers can also be the victims of

\footnotetext{
2 Theoretical analysis distinguishing between extortion and voluntary bribes is in Mookherjee (1998) and Hindriks, Keen, and Muthoo (1999). See also Marjit, Mookherjee, and Mookherjee (2000).

3 See Caseley (2004).

4 A Transparency International 2002 survey suggests that most bribes are paid directly to officials rather than to middlemen, at least in the case of India. One exception to this is property registration as documented by Caseley (2004).
} 
TABLE 8.1 Corruption in Tanzania's tax and customs administration in the mid-1990s

\begin{tabular}{|c|c|}
\hline Type of corruption & Mechanisms and extent \\
\hline \multicolumn{2}{|c|}{ External corruption (involves both tax officers and taxpayers directly) } \\
\hline VAT fraud & Falsified VAT refund claims. Can involve TA officials. \\
\hline $\begin{array}{l}\text { Diversion of goods in transit to } \\
\text { the domestic market }\end{array}$ & $\begin{array}{l}\text { Tanzania is a transit country for import of goods to Burundi, } \\
\text { eastern DR of Congo, Rwanda, Uganda, and Zambia. A review } \\
\text { in } 1996 \text { concluded that at least } 50 \text { percent of transit imports } \\
\text { were diverted to the domestic market. }\end{array}$ \\
\hline False classification of goods & Can involve customs officers. \\
\hline Underreporting value of goods & $\begin{array}{l}\text { To avoid preshipment inspection of goods in the export country, } \\
\text { shipments may be made so that each shipment is below the } \\
\text { inspection threshold. Customs and excise officers may be involved. }\end{array}$ \\
\hline $\begin{array}{l}\text { Exemption by misclassified } \\
\text { taxpayer status }\end{array}$ & $\begin{array}{l}\text { Involves the TA, the Ministry of Finance (MoF), and Tanzania } \\
\text { Investment Centre (TIC). Unregistered tax payers pay a lower tax } \\
\text { "privately" to tax collectors. Second, goods can be reported as } \\
\text { imports by exempt organizations. }\end{array}$ \\
\hline Extortion & $\begin{array}{l}\text { Taking advantage of taxpayers' incomplete knowledge of tax } \\
\text { legislation, tax collectors threaten taxpayers to increase rates } \\
\text { and assume that taxpayers will not be financially able to press } \\
\text { charges. Small businesses, such as hotels and restaurants, claim } \\
\text { this is a big problem. }\end{array}$ \\
\hline \multicolumn{2}{|c|}{ 3. Internal corruption within the tax administration (does not involve taxpayers directly) } \\
\hline $\begin{array}{l}\text { Embezzlement of collected } \\
\text { revenue }\end{array}$ & May involve collusion of bank employees. \\
\hline Fraud & Falsifying tax receipts. \\
\hline Corrupt auditors & $\begin{array}{l}\text { Internal auditing within customs is considered inefficient and } \\
\text { corrupt. Undermines the credibility of the monitoring policy. }\end{array}$ \\
\hline
\end{tabular}

Source: Adapted from Fjeldstad 2002, table 8.3.

extortion. Given this diversity, a multichannel approach to intelligence gathering to discover different types of corruption is needed. Furthermore, the design of penal sanctions for corruption needs to take account of the diversity of actors as well as the motivations for corruption.

On motives for corruption, the importance of "cost recovery," if TA officials are required to pay for posts, postings, or other expenses to retain their positions, has already been pointed out. ${ }^{5}$ Causes of rising corruption in the Uganda Revenue Authority (URA), which was perceived to have declined after the URA's inception in 1991, include, according to Fjeldstad, (i) declining real wages even though the average level 
remained well above the general civil service; (ii) poorly designed bonus systems and revenue targets; (iii) rehiring and failure to fire corrupt staff; (iv) lack of job security for top managers; (v) political interference in staff appointments due to their relatively high wages; and (vi) cultural norms with regard to kinship ties and resulting patronage expectations. In particular, cultural norms in the case of URA officials represented an important challenge in combating corruption. According to Fjeldstad (2005):

". . . when someone gets a job in the tax administration he or she is expected to help his or her kin and family. Because Ugandans perceive that URA officers receive high salaries, extended family members expect to get their share of the high wages. It is one's social obligation to help and share. URA staff are therefore seen by their family members and social networks as important potential patrons who have access to money, resources, and opportunities that they are morally obliged to share. A person in a position of power is expected to use that influence to help his or her kin and community of origin. Hence, increased salaries may lead to increased social obligations, which again may 'force' tax officers to take bribes to compensate for the higher expenses" (page 13).

The importance of cultural differences, therefore, must be seen as a crucial ingredient in the design of anticorruption strategies.

On the relationship between corruption and tax evasion, it should be noted that the link is not rigid. While most types of voluntary, collusive corruption should have a direct negative impact on tax revenue, other forms of corruption may have only an indirect impact on revenue or, alternatively, the budgetary cost or efficiency of TA.

\subsection{Tax Simplification and Corruption}

Anticorruption strategies should focus first on limiting motives for corruption and second on opportunities for TA officials to abuse their positions. In limiting opportunities, the most important element is possibly the design of the tax system itself. A recent study (World Bank and PriceWaterhouseCoopers 2007) reiterates this view and presents some suggestive evidence:

"Simplifying the tax regime by reducing tax rates and eliminating exemptions is the main way to reduce corruption in tax administration. Georgia-which introduced major reductions in tax rates and simplifications to the tax system in 2004 - has seen a drastic fall in perceived corruption of tax officials. In 2005, only 11 percent of surveyed businesses reported that bribery was frequent, down from 44 percent in 2002. That was the sharpest drop in perceived corruption among the 27 transition economies. Romania, another major reformer in 2004, and Slovakia, which introduced large tax reforms in 2003, also saw falls in perceived corruption: from 14 percent to 8 percent of surveyed businesses and from 11 percent to 5 percent, respectively" (page 14). 
This prescription, particularly with respect to high tax rates but also with respect to cumbersome and nontransparent procedures, is supplemented by the following:

"Burdensome taxes do, however, generate other undesirable outcomes. They are associated with more informality, as entrepreneurs often choose to avoid the formal system altogether and operate underground. They also breed corruption. Businesses ranking in the bottom 30 countries on ease of paying taxes are twice as likely as those in the top 30 to report that informal payments are a problem. Every point of contact between a bureaucrat and an entrepreneur could present a danger of bribery and confusion on voluminous, often contradictory rules which may create room for discretion" (World Bank and PriceWaterhouseCoopers 2007:14).

This echoes the case for tax simplification put forward in earlier chapters in that (i) high and burdensome taxes provided enhanced incentives for tax evasion, which in turn enhance the motive for collusive corruption, and, more important, (ii) opportunities for corruption can largely be traced to tax provisions that confer discretionary power on TA officials.

The prescriptions for reducing corruption through tax simplification that follow from this position are no different from prescriptions for tax design to reduce TA costs and taxpayer compliance costs. The major points can be summarized as follows:

- Reduce tax rates and broaden the tax base by eliminating exemptions and concessions to the extent possible.

- Where concessions are retained, they should be granted as far as possible by means of transparent, nondiscretionary, and auditable written rules and procedures, without the need for direct interaction between TA officials and taxpayers.

- Clearances and permissions for different types of taxpayer activities ${ }^{6}$ should similarly be granted via transparent, nondiscretionary, and auditable written rules and procedures.

- In cases of specific provisions (for example, levy of penalties and interest, collection of delinquent taxes) the TA law should first be made nondiscretionary. The second step is to provide for their implementation via nondiscretionary and transparent rules and procedures.

\footnotetext{
6 See chapter 5 for examples.

7 For example, penalty provisions should specify nondiscretionary penalty amounts or penalty calculation rules. Furthermore, waiving of penalties should be permitted, if at all, only by a suitably highranking TA official or, preferably, a formal TA committee constituted to look into such matters-and even then, the procedure for waiving penalty should be written down and nondiscretionary.
} 
- To simplify taxes in complex and evasion-prone areas (examples include depreciation, entertainment expenses, and commodity tax valuation), presumptions that reduce computation and recordkeeping needs (and in the process reduce TA discretion) are important.

- Similarly, presumptive small taxpayer's regimes and presumptive taxes for the hard-to-tax can reduce compliance costs and tax evasion and TA discretion and corruption.

- As a deterrent, a taxpayer complaint mechanism should be established, ideally in conjunction with the TA's internal audit function.

- The compensation and performance evaluation scheme for TA staff should positively reward behaviors that deter corruption.

Two additional elements can be added to this list:

- For corruption-prone TA functions (for example, granting refunds), special reporting requirements should be put in place.

- In all these cases, management supervision should be required and both concerned TA officials and their supervisors should be held accountable for nonadherence to legal provisions and procedures.

\subsection{Designing an Anticorruption TA Strategy}

Beyond the simplification of tax provisions, rules, and related procedures, an effective anticorruption strategy for a TA must also focus on motives and opportunities for corrupt activity by TA officials more generally. This broader perspective in the design of anticorruption strategy is the focus of this section.

The important principle to be kept in mind while designing an anticorruption strategy is that TA performance or efficiency and effectiveness enhancement is the primary goal. Reducing corruption is not an end in itself. However, reforms that enhance performance usually contribute to lower corruption. This follows, since corruption directly undermines TA performance, either by undermining revenue collection or by raising TA or taxpayer compliance costs. Nevertheless, it should be noted that the effectiveness and efficiency of a corruption-prone TA will tend to be lower than that of an incorruptible TA, since implementing anticorruption strategies can entail additional costs and diversion of resources from the primary TA tasks described in chapters 5 and 6.

The institutional structure for TA performance orientation outlined in table 5.1 has many features that also potentially reduce corruption. ${ }^{8}$ To elaborate, Das-Gupta,

\footnotetext{
8 The five-fold classification of institutions in table 8.1 includes institutions for (i) clarity of goals; (ii) measuring goal achievement or performance; (iii) enabling performance; (iv) communicating performance; and (v) rewarding and motivating performance.
} 
Engelschalk, and Mayville (1999) identify a set of institutions (and enhanced use of technology and information inputs) that potentially reduce motives and opportunities for corruption. As can be seen (table 8.2), many of these institutions form part of the performance institutions in table 5.1. The main difference between the two structures is in the increased emphasis on transparency and written procedures and in the emphasis placed on rewards and sanctions and, of course, tax simplification. Table 8.2 elaborates on the new elements potentially present in an anticorruption strategy, which may be seen to be complementary to performance-enhancing institutions.

TABLE 8.2 Anticorruption TA institutions

\begin{tabular}{|c|c|}
\hline Institutions that address motives & Institutions that address opportunities \\
\hline Basic motivation & Tax structure reforms \\
\hline Mission and vision statements & Low and few rates and limited exemptions \\
\hline Elite ethos and esprit de corps & Withholding and presumptive taxes \\
\hline Positive incentives & Nondiscretionary penalties \\
\hline Organizational autonomy & Organization and management \\
\hline $\begin{array}{l}\text { Transparent budget procedures and } \\
\text { performance-linked budgets }\end{array}$ & Functional organization \\
\hline Performance-linked compensation & Increased use of third-party data \\
\hline Intra- and interagency competition & Limited contact with taxpayers and suppliers \\
\hline Competitive base pay & $\begin{array}{l}\text { Arm's-length, transparent, and } \\
\text { nondiscretionary business procedures }\end{array}$ \\
\hline $\begin{array}{l}\text { Transparent and nonarbitrary reward } \\
\text { procedures }\end{array}$ & $\begin{array}{l}\text { Transparent human resource, procurement, } \\
\text { and budgetary procedures }\end{array}$ \\
\hline Negative incentives & Computerization and automation \\
\hline Effective sanctions for corruption & Privatization of selected functions \\
\hline $\begin{array}{l}\text { Stronger taxpayer voice through } \\
\text { independent surveys }\end{array}$ & Internal and external checks \\
\hline Citizen review and oversight & Independent internal and external audits \\
\hline Supply-side elements & Effective management supervision procedures \\
\hline \multicolumn{2}{|l|}{ Effective sanctions for bribe payers } \\
\hline $\begin{array}{l}\text { Independent institutions to protect } \\
\text { taxpayers from harassment and extortion }\end{array}$ & \\
\hline Publicity for penalties & \\
\hline
\end{tabular}




\subsubsection{Elite ethos and esprit de corps}

The only sure cure for corrupt practices is an attitudinal change that makes corruption socially and ethically unacceptable. In the absence of effective methods to achieve such an attitudinal shift, especially in the short run, a possible substitute is to foster esprit de corps and pride in one's department coupled with staff education regarding the TA's code of ethics. This reinforces the importance of a vision statement and a shared sense of purpose. A small additional step that may possibly enhance the effectiveness of measures to foster institutional pride is requiring the wearing and display of logos, badges, and insignia by staff while on duty as is done in some customs administrations.

\subsubsection{Performance incentives}

In the absence of assured attitudinal reform, the second best alternative is to influence staff motives through a system of positive and negative incentives. Such incentives can be designed to apply to individual staff, functional or regional organizational units, or the TA as a whole.

Negative incentives ("sticks"), for example, sanctions on TA officials who do not comply with legal provisions and prescribed procedures or in the case of detected corruption, are important. However, negative incentives alone can deter not just corruption, but also the will of revenue officials to work, and may cause them to inadvertently violate rules and procedures. For this reason, positive incentives ("carrots") are crucial to ensure that the TA is in fact interested in good performance?

A major type of negative incentive is a system of effective sanctions for corruption. These sanctions should be legally prescribed for TA officials and other officials colluding with TA officials. They should apply not only to direct cases of bribery or embezzlement but also to indirect indicators, such as unexplained increases in the wealth of TA officials or their close family. Supply-side penalties for taxpayers who pay bribes are also of importance. In particular, increasing globalization requires that attention be paid to bribe activity by foreign taxpayers, ${ }^{10}$ though this may be less important in the tax arena as compared with, say, government contracts. ${ }^{11}$ The important point is that such sanctions should be effective, which requires effective management control and implementation. This, in turn, usually implies the involvement of government agencies outside the TA.

\footnotetext{
9 See Mookherjee and Png (1995) and also Mookherjee (1998) for a theoretical analysis of the balance between positive and negative incentives for TA.

${ }^{10}$ Bribe payments by corporations are emerging as an important source of corruption despite such deterrents as the OECD antibribery convention and the United States' Foreign Corrupt Practices Act, 1977. For a review of the supply-side of bribes see Vogl (1988). For recent news stories see Beales (2007) and Hughes and Wright (2000). Also see Das-Gupta and Wu (2008).

${ }^{11}$ A separate issue not within the scope of this chapter is the use of TA officials to detect bribes paid by taxpayers to other government units they deal with. From the point of view of tax revenues one reason for this, for example, is to disallow bribery expenses by the taxpayer where they are not allowable. Detailed guidelines for such examinations are in OECD (2006).
} 
Also important to detect and provide incentives for effective deterrence of corruption are taxpayer voices elicited through independent surveys. Independence can be ensured through a variety of channels, examples of which are discussed and presented in this chapter.

Positive incentives for good performance are also needed at all levels. Individual incentives, if they have a monetary component, act as a counterweight to ill-gotten bribes and gratuities.

The introduction of performance indicators along with safeguards against unintended mistakes allows this to be done objectively and transparently. Comparison between individuals and TA units (whose performance can be compared) and linking rewards for good performance can be used to foster competition between units to deliver good performance. If there is more than one TA (for example, domestic taxes and customs departments), then both intra- and interagency competition can be used to provide performance incentives. For this to be possible, of course, performance indicators need to be developed and used, ${ }^{12}$ and incentives for good performance by individuals and divisions in a department should ideally be built into the system of monetary compensation. ${ }^{13}$

The importance of competitive base pay-in addition to transparent and nonarbitrary rewards- has been widely discussed. Beyond the desire to attract highcaliber staff, the rationale for high pay is to make TA officials value their jobs so that they will be reluctant to jeopardize their employment by transgressing rules or engaging in corruption. Little analysis has been done, however, to determine the size of the base salary needed to reduce corruption. ${ }^{14}$

\subsubsection{Performance-linked budgets}

At the level of the TA as a whole, one of the main tools to foster performance orientation is the TA budget. Budgets should typically be based on an agreement between the parent ministry and the TA that generates parts of the TA budget on the basis of performance. Beyond revenue collections, improvement or deterioration in citizen services, compliance costs, and performance in implementing long-range plans could be incorporated into budget determination and release rules. In part, performance assessment should be based on independent citizen feedback. ${ }^{15}$

12 Though a detailed discussion of performance indicators for tax administration is not within the scope of the current chapter, a brief introduction is provided at the end of the chapter.

${ }^{13}$ Evidence on the impact of performance incentives in the case of the Brazilian tax administration is in Kahn, Silva, and Ziliak (2002).

${ }^{14}$ The observation on pay by Fjeldstad (2005) is worth noting: ". . pay level is only one of several factors affecting the behavior of tax officers. In an environment where the demand for corrupt services is extensive and monitoring ineffective, wage increases may end up functioning as an extra bonus on top of the bribes taken by corrupt officers" (p. 14).

15 To ensure that short-term performance does not dominate the TA's planned activity, training budgets and long-term capital budgets should typically be kept out of the budget determination rules. Alternatively, these budget components should be kept separate from the component linked to current performance. 


\subsubsection{Citizens' review and oversight}

The institutionalization of citizens' review of certain TA activities where discretion is largely unavoidable is a measure that helps curb corruption in such TA activities. For example, adverse audit findings leading to taxpayer penalties or possibly criminal sanctions can be subject to formal review by citizen bodies constituted for this purpose, as has been done in Mexico and Sweden. Other activities that such bodies could review include denial of permission to register or lengthy delays in processing refund claims. In addition, such bodies could be given the discretion to ask to examine cases without adverse audit findings in response to complaints by other citizens. Such review bodies could either complement or substitute such other grievance channels as the tax ombudsman.

Beyond the simplification of tax laws and related rules and procedures in order to reduce opportunities for corruption, some other areas of TA can also be streamlined. For most of these areas, transparency and openness are the key drivers of measures suggested.

\subsubsection{Transparency}

As a recent commentary puts it:

"Transparency is a key issue for all revenue administrations. Increased accountability and an open and honest relationship with taxpayers are crucial for maintaining public trust and confidence in the performance of tax administration. Taxpayers must be able to expect a high degree of certainty in their dealings with revenue agencies. This can only be achieved when tax laws, regulations, procedures, and administrative guidelines are made public, easily accessible, and applied in a consistent manner. Any deviations from laws, regulations, and discretionary power should be justified and documented for later review" (CMI 2005).

\subsubsection{Transparent human resource, procurement, and budgetary procedures}

One key source of corruption mentioned earlier is in the area of personnel management. This encompasses the three major areas: posts and recruitment, postings and retention, and promotion to a particular position. While there are no foolproof safeguards, transparency and open scoring and assessment, written procedures subject to audit, and an explicit link to past performance and capacity for and experience in different posts are some safeguards that can be implemented. Transfers of staff to postings in high demand should also be made transparent and be based on the performance of eligible staff with the necessary experience. 
As in other areas of government, transparency in procurement and providing procurement procedures with safeguards against abuse are also important.

In terms of TA budgets, one suggestion for performance orientation made here is for operational autonomy of TA management. In particular, budget allocations to different departments or regional offices and also allocation of budgetary resources to direct performance-linked bonuses will have a significant influence on performance. Furthermore, allocations can become a source of corruption if they are open to negotiation or "bidding." Requiring transparency and rationality in budget allocation procedures within the TA is an important check that needs to be instituted along with management autonomy.

\subsubsection{Limited contact with taxpayers and suppliers}

Several studies have affirmed that increased interaction between taxpayers and tax authorities increases the potential for corruption. Excessive contact between taxpayers and tax officials should, therefore, be avoided. Important instruments in this regard include relying on withholding taxes, increasing the use of third-party data for tax assessment, and privatizing selected functions of the TA. In situations where TA functions are carried out by private parties, every effort should be made to ensure that the TA's corruption safeguards are adhered to and monitored, to ensure that corrupt practices do not simply "transfer" to the private entity. Effective automation of procedures also facilitates reduced contact and increases administrative efficiency. To institutionalize this effectively, arm's-length, transparent, and nondiscretionary business procedures need to be developed and used in the preparation of a business procedures manual. TAs should seek also to move to a "riskbased" assessment of taxpayer returns to limit the potential for unnecessary contact between TA officials and taxpayers regarding relatively insignificant issues.

\subsubsection{Effective management supervision procedures}

Such procedures are required to ensure performance orientation in general and adherence to anticorruption measures in particular. To ensure that management supervision is effective, management performance monitoring by top management and by external audits should focus on key activities. To enable this to be systematically done, guidelines for managers to deal with corruption should be developed and become the subject matter of regular management training programs. Important anticorruption areas that should be subject to supervision include (i) systematic monitoring and review of cases where exercise of discretion is unavoidable, ${ }^{16}$ (ii) monitoring declarations of

\footnotetext{
${ }^{16}$ For an example, see the audit case study in Box 6.1, particularly steps 7, 8, and 9.
} 
income and assets by TA officials and investigating cases of illicit enrichment that come to light, and (iii) quality and timeliness of disciplinary proceedings.

\subsubsection{Privatization of selected functions}

The general approach to outsourcing to improve TA performance was dealt with in chapter 5. By limiting TA corruption opportunities, outsourcing can be an effective means of reducing corruption if judiciously employed. However, as the important case of preshipment inspection presented in box 8.1 illustrates, privatization is by no means a panacea for corruption. ${ }^{17}$

\subsubsection{Publicizing corrupt behavior}

Publicizing corrupt practices of TA officials and businesses can have a significant deterrent effect on corrupt behavior. The potential shame and humiliation of unethical behavior can play a role in deterring officials. Also, many businesses seek to promote their image as responsible corporate citizens to win favor with the public. Publicizing corrupt practices can be a significant deterrent to businesses because of

\section{BOX 8.1 Preshipment Inspection to Curb Customs Corruption}

Preshipment inspection (PSI) services are provided contractually to customs administrations by private firms in countries from which the contracting country's imports originate. The experience of some countries showed that PSI service providers could rival the customs administrations they supplemented in corrupt practices. According to CMI 2005:

"Private management of tax administration is raised as a possible approach, but such reforms have achieved few lasting results. The transfer of skills by foreign contractors has been limited and such contracts have been very expensive for the government. Tax practitioners are therefore increasingly questioning the value of outsourcing tax administration. In Customs, for instance, outsourcing other activities such as valuation and entry processing is risky, since it places the collection of government revenue directly into the hands of nongovernment interests. In countries with a high level of corruption, there is no reason to believe that those interests will be any less corrupt. Placing private Customs personnel in line jobs in operational units may compound the current failure to manage and, thus, entrench the problems. Instead it might be a better approach to upgrade the revenue administration's own capacity to carry out these tasks."

Yet, a recent study (Yang 2005) found that that PSI helps improve the annual growth rate of customs revenue in countries that have intelligently drawn up their contracts with PSI firms, by 6 to 8 percentage points, primarily by reducing customs corruption. This illustrates an important point about tax administration reforms: It is often the case that the devil is in the details.

\footnotetext{
${ }^{17}$ For discussion and evaluation of PSI, see Low (1995), Johnson (2001), and Yang 2005.
} 
the negative publicity and the resulting decline in sales, decline in favorable contracts, and decline in the ability to recruit talented employees.

\subsubsection{Protecting taxpayers}

Next to tax system reform, perhaps the most important set of components to curb opportunities for corruption is a system of internal and external checks and effective channels to deal with citizens' grievances. Internal audit divisions and anticorruption units are the most important anticorruption bodies within TAs. Ideally, these institutions should be able to build on an automated TA database system. Important institutional safeguards outside the TA include an independent and effective judiciary, external reviews by government agencies (such as independent external audits), taxpayer associations that strengthen citizens' voices, and independent grievanceredressing institutions such as ombudsmen. Such options are discussed further.

\subsection{The Role of Technology}

A general discussion of automation and the introduction of IT in TA was presented in chapter 5 . The focus here is on the role IT and automated databases can play in an anticorruption strategy.

Through automation and IT-enabled procedures, several aspects of TA activity become less vulnerable to corruption if potential benefits are explicitly designed for. Any such automation would need at least five important elements.

- A tamper-proof database. Security against unauthorized tampering with data can be ensured for taxpayer master files, current accounts, and return-based data. The level and extent of this security depend on the extent of automatic data capture as well as TA organization and the extent of database access. The ideal system will permit automatic data capture directly from taxpayers in the first instance, followed by automatically maintained records of subsequent revisions of the same data. Such data should be part of a central database and not one that is solely accessible by one decentralized body, such as a local tax office. Two examples can help illustrate this.

Tax return data can be captured online with electronic filing of tax returns. Return data, once filed, can be maintained as is without further alteration except by the taxpayer concerned. However, a revised tax return should not lead to the erasure of the initial return from the database, and database access statistics should clearly indicate the history of the return. Similar treatment should be accorded to tax information relevant to the tax returned after each check or audit by the TA. The date of modification and the identity of the person making the authorized modification should also be automatically recorded in the access history. 
With respect to tax payments and assessed dues in a current account, data should be automatically generated from the payment office or bank receiving the payment; the history of subsequent updates and payments should be recorded in the same manner as for tax returns.

In reality, this ideal may not be reached, given the prevalence of manual return filing and data capture or decentralized database maintenance. Automatic recording of access history and the identity of authorized individuals updating data also may not always be maintained. Even so, provided only authorized persons can modify data, and provided copies of databases are maintained at more than one location, this reduces opportunities for data tampering.

- Data mining. To detect duplicate or imaginary taxpayers and taxpayer identification numbers.

- Automatic recording of receipt of different documents and requests for service. This reduces the scope for "out-of-turn" favors and makes service delays more readily subject to management scrutiny.

- Nondiscretionary and standardized procedures for such things as making tax demands, issuing tax notices and permissions, and processing of refunds. Mandatory checklists for activities requiring direct interaction between TA officials and taxpayers, including tax audits, inspection visits, and customs and other checkpost procedures also help reduce unauthorized discretion.

- Identification of TA staff and supervisors responsible for particular actions. This permits a statistical analysis of their effectiveness and can promote individual accountability. For example, responsibility for nonadherence to procedures or incorrect assessments can be traced, in principle, to responsible officials. This could directly form the basis for follow-up investigations or, with appropriate data mining, statistical profiling of TA officials to identify suspicious patterns of decisions by them.

It should be emphasized that to be effective, the IT system must be designed to deliver such benefits and must be introduced along with organizational and human resource procedures. As the two Indian cases below vividly illustrate, technology without institutional and human resource reform is likely to prove ineffective in curbing corruption.

\subsection{The Role of Internal and External Audit and Vigilance}

Internal and external audit are prevalent in institutions that are primarily focused on management effectiveness and accountability. In contrast, vigilance is explicitly directed at curbing corruption. 


\section{BOX 8.2 Two Examples of IT Integration in India}

\section{Example 1: Sales tax check posts in Gujarat}

The Indian state of Gujarat automated its major border checkposts in 1999, allowing IT-assisted examination of trucks, faster document processing, and online sharing of information with other sales tax offices in the state. Revenues jumped by Rs. 970 million in 1999, Rs. 1670 million by 2000, and Rs. 2370 million by 2001. However, due to "faulty maintenance," 42 out of 58 checkposts had nonfunctioning equipment in $2002 .{ }^{18}$ The lesson from this example is that introduction of advanced and sophisticated equipment without addressing human incentives can prove to be ineffective. TA staff posted at checkposts suffered from a loss of illegal income. No counteracting benefits or negative incentives were provided to realign their individual interests with TA performance and revenue goals.

\section{Example 2: The CARD project in Andhra Pradesh}

Stamp duties and registration fees are among the three most important taxes in Indian states. The project for Computer-aided Administration of the Registration Department (or CARD) to automate and improve the speed and quality of registration services in Andhra Pradesh has received much national and international attention. Under CARD, several subregistries in Andhra Pradesh were equipped with document scanners and online document storage using writeable CDs. Software was introduced to record and control registrations and make the registration process transparent and time-bound. But nothing was done to change the basic culture of the subregistries, nor to do away with the ubiquitous touts who are to be found outside these offices.

Jonathan Caseley (2004) surveyed over 300 citizens in rural Andhra Pradesh who had registered property sale deeds. He concluded that ". . . it still takes days to register a document and CARD has simply made corruption at the [Department of Stamps and Registration] easier." The study presents evidence to show that the incidence and quantum of bribes were similar in both CARD and non-CARD subregistries. Though the time taken for registration had decreased in CARD offices, there was no impact on "information transparency, staff behavior and the payment of bribes." In fact, 87 percent of interviewed citizens had not been given official receipts for duties and fees paid by them.

\subsubsection{Internal audits}

Good management controls should have both ex ante and ex post components. Ex ante control functions ensure that organizational objectives (i) are carried out effectively and efficiently in terms of procedures prescribed and their timeliness, (ii) limit the risk of waste and fraud, and (iii) are citizen-friendly. Ex post control, in contrast, is designed to (i) identify areas where management controls of business processes need to be improved, (ii) identify risk areas, and (iii) possibly provide input into the desirability of changes in TA business processes such as outsourcing. Ex post control is typically the function of internal audits. A subsidiary objective, but the one of concern here, is to collect evidence to help establish accountability.

\footnotetext{
${ }^{18}$ This example is based on Pandey (2002).
} 
Internal auditing is done by an independent unit (separate from normal operations management) that reports to senior managers playing an advisory, nonadversarial role. It should provide feedback to management on such things as (i) the effectiveness of management controls in relation to procedural violations, with reference to written procedures and manuals, (ii) the controls' timeliness, (iii) management failure to detect and correct violations by TA officials, and (iv) wasteful expenditure.

To be an effective tool for management control, the work program and budget of the internal audit division should be decided in advance at the beginning of the work year, together with other TA functions. The work program should typically include audit investigations of most TA activities on a sample ("test check") basis as well as in-depth audits of risk areas identified earlier.

Though internal audits focus on improving management effectiveness, they can have a significant impact on corruption in certain TA environments. CMI (2005) points out of the relation between wage incentives and audits in the design of anticorruption strategy:

"The degree of audit intensity may determine the effectiveness of the wage level as an anticorruption tool. Recent research has found the effects of higher wages on corruption-when audit levels are low and corruption high-to be zero, while they are negative when audit and corruption levels are intermediate. In settings where the auditing intensity is high and the corruption level is low, the effect of higher wages on corruption is found to be positive but low. These results imply that wage incentives should be linked to and not isolated from other measures."

\subsubsection{External audits}

Independent external audits have less of a management focus. They review TA functions in order to report on the TA's effectiveness and efficiency to the legislature or president of the country. Therefore, although there is an overlap between external and internal audits in terms of the scope of their activities, external audits are explicitly targeted at establishing executive accountability to the nation. The role of external audit has been articulated in the Lima Declaration (1977) of the International Organisation of Supreme Audit Institutions (INTOSAI): ${ }^{19}$

“. . audit is inherent in public financial administration as the management of public funds represents a trust. Audit is . . . an indispensable part of a regulatory system whose aim is to reveal deviations from accepted standards and violations of the principles of legality, efficiency, effectiveness, and economy

\footnotetext{
19 The International Organisation of Supreme Audit Institutions, INTOSAI, which has around 170 members, prescribed audit standards for supreme audit institutions in different countries in the Lima Declaration at its IXth Congress in 1977.
} 
of financial management early enough to make it possible to take corrective action ... to make those accountable accept responsibility, to obtain compensation, or to . . render more difficult . . such breaches."

Per the Lima Declaration, countries should have Supreme Audit Institutions (SAIs) that are independent of the executive to (i) detect misuse of public funds, (ii) determine the reliability of financial data and budget execution reports, (iii) identify waste and inefficiency, and (iv) provide reliable data on program results.

SAI functions include (i) laying down standards for the audits, (ii) conducting audits, and (iii) reporting to the legislature or the president of the country and assisting in legislative or presidential oversight committees. It may also, like internal audit, assist in management control and in reorganization or revision of management procedures.

There are generally four types of SAI audit, though the extent of their use varies with the sophistication and capacity of each country's SAI. Ex ante audits of individual transactions before any financial payments are made are part of management control and of limited relevance to a TA. Regular audits are carried out on a sample basis to ensure compliance with procedures and to prevent future irregularities. To be effective, proper management follow-up procedures need to be in place. Financial audits are similar to audits in the private sector and are sample-based audits designed to ascertain the reliability of data in government accounts, financial reports, and budgets, including, where required, an assessment of accounting systems and controls. Typically, in highly technical or specialized areas, these audits are outsourced to specialist auditors. Value-for-money audits (UK) or performance audits (U.S.) are broadly focused audits that require in-depth examination of the economic, efficiency, cost-effectiveness, and environmental effects of government activities.

\subsubsection{Vigilance activities}

Vigilance activities can be carried out either by external specialists who are part of a country's anticorruption machinery or (though this is less desirable) by an independent unit reporting to the head of the TA. Vigilance is directed explicitly at curbing unilateral and cooperative corruption of TA officials. Vigilance inquiries are typically reactive and are triggered against individual officials or groups of officials by complaints from the public, by taxpayers, or by adverse audit reports. Where adequate online databases on tasks performed by different officials are available, enquiries may also be triggered by a prearranged data-mining exercise. To be effective, the investigative powers of vigilance staff should be extensive in relation to TA officials and the tasks they perform. Vigilance staff should also have the power to hold formal inquiries and to determine how likely TA officials are to abuse their positions. If independent of the TA, vigilance staff should also have the power to impose sanctions on 
guilty officials - short of criminal sanctions. Internal vigilance units typically recommend sanctions only to the head of the TA.

Internal and external audit are important institutions to assure management effectiveness and accountability. In relation to corruption, however, the functions of a vigilance unit may overlap with those of a tax ombudsman unless their mutual spheres of action and powers are explicitly demarcated. One important source of complementarity is that almost all ombudsmen look at taxpayer problems and grievances only when approached by taxpayers. Therefore, while they may play a valuable role in combating extortion and harassment, they will have less impact, if any, on collusive corruption between taxpayer and TA official.

\subsection{Dispute and Grievance Resolution Mechanisms and Tax Ombudsmen}

As introduced in chapter 5, ombudsmen are institutions that look into complaints about an organization. They are generally independent, cost nothing to persons approaching them, and are partial toward neither the complainant nor the concerned organization. Generally, the ombudsman can be approached only if a direct complaint to the organization does not resolve an issue.

Ombudsmen in the area of TA are widely employed in both developed and developing countries. Most follow the general practice of reacting only to complaints received from citizens. Their powers usually extend only to administrative issues and not to matters relating to tax dues and penalties levied-though associated procedures do fall within their scope of enquiry. Beyond this, the scope of their activities varies widely.

At one extreme is that of the United States National Tax Advocate. The Taxpayer Bill of Rights 2, enacted by the U.S. Congress in 1996, established the Office of the Taxpayer Advocate within, but independent of, the United States Internal Revenue Service (IRS), replacing the tax ombudsman. Its functions are to help taxpayers resolve their problems with the IRS and identify administrative and legislative measures that might reduce systemic problems. It does the former through what is termed "case advocacy" and the latter through a structure of statutory annual reports to the United States Congress covering systemic problems. The independence and impartiality of the Taxpayer Advocate Service (TAS) is upheld by a separate reporting structure in which all employees report directly to the National Taxpayer Advocate. ${ }^{20}$

\footnotetext{
${ }^{20}$ See United States Internal Revenue Service 1997, 2001, and 2008.
} 
In Sri Lanka, for another example, the tax ombudsman has broad powers, explicitly including official corruption and dereliction of duty-but no responsibility for advocating systemic reform. The government of Sri Lanka, Ministry of Finance and Planning (2008), describes the ombudsman's powers and duties as follows:

"The Ombudsman will inquire into complaints of any injustice arising in consequence of any maladministration on the part of any officer of the Department of Inland Revenue. Maladministration in this context is defined to include,

A decision, process, recommendation, act of commission or omission which appears to: be a departure from established practice; be arbitrary, unreasonable or discriminatory; have been given on irrelevant grounds; or involve the exercise of powers, or the failure or refusal to do so, for corrupt or improper motives or as administrative exercises.

Neglect, inattention, delay, incompetence, inefficiency, and ineptitude in the administration or discharge of duties and responsibilities.

Repeated notices, unnecessary attendance, or prolonged hearings while deciding cases concerning determination of income or value; assessment of liability to taxes or levies administered by the Inland Revenue Department; classification or valuation of goods; settlement of claims of refunds or rebated; or determination of fiscal and tax concessions or exemptions.

Willful errors in the determination of refunds or rebates; deliberate withholding or nonpayment of refunds or rebates already determined.

The Ombudsman will entertain any complaint made directly by the person aggrieved in writing and addressed to tax Ombudsman within a period of six (6) months from the date on which the complainant had first notice of the injustice complained of."

At the other extreme is, for example, the income tax ombudsman in India, whose powers and areas of responsibility are very limited. Section 8 of the Income Tax Ombudsman Guidelines (2006) specifies its powers and duties. ${ }^{21}$ The ombudsman can receive complaints from taxpayers, but only on specified matters, and resolve them through reconciliation or by making an award. The ombudsman is also required to report findings to the appropriate overseeing authorities in the MoF to identify and recommend action against responsible officials. The ombudsman's findings are required to be taken into account in the performance appraisal of concerned officials. Similar to the U.S. NTA, the ombudsman is tasked with identifying and reporting - in an annual report-procedural weaknesses that increase taxpayers' compliance burden. As can be seen, in India the

${ }^{21}$ See Government of India, MoF (2006). 
ombudsman is an administrative position within the MoF, which, in contrast to the United States, presumably limits the office's independence and influence.

Section 9 of the Indian Guidelines (Income Tax Ombudsman Guidelines 2006) specifies the limited areas in which the ombudsman can entertain taxpayer complaints. These include (i) delays in issue of refunds beyond prescribed time limits and other abuses alleged in relation to refunds; (ii) other administrative delays, such as those related to interest waivers or rectifying mistakes in assessment; (iii) complying with appellate orders, allotting taxpayer numbers, and returning seized books of account and assets of taxpayers; (iv) not acknowledging letters or documents sent to the department; (v) not updating taxpayer records, leading to their harassment; (vi) lack of transparency in identifying and selecting cases for tax audits; (vii) not crediting taxes paid by taxpayers to their accounts; (viii) failure of TA officials to work during prescribed working hours; and (ix) unwarranted rude behavior by TA officials. While not without a potential impact on taxpayer compliance costs and reduction of TA corruption opportunities (and improving services by the TA), the limited scope contrasts sharply with the other two countries reviewed.

The important point to note is that in all cases the ombudsman is a second safeguard channel after the TA has been directly approached to resolve procedural problems and grievances. Possible channels for this, typically as a part of the taxpayer service function, were discussed in chapter 5.

\subsection{Concluding Comments: Sequencing Anticorruption Reforms}

Implementation of a fully articulated anticorruption strategy such as that outlined in this chapter is likely to be impossible in most countries, and at any rate very costly. Thus a gradual and sequenced reform path is probably the best course to follow. The first and least costly step is to simplify taxes. The second is to enact other enabling legislation and rules such as making penalty structures nondiscretionary and comprehensive and codifying transparent and nondiscretionary procedures. Appropriate sequencing of other reforms and institutional measures will vary from country to country. One general principle that may be suggested is to introduce measures that have a positive impact on TA performance in general and that are not narrowly conceived of as anticorruption measures. ${ }^{22}$

\section{Further Guidance}

- D. Mookherjee. 1998. "Incentive Reforms in Developing Country Bureaucracies: Lessons from Tax Administration." Proceedings of Annual World Bank Conference in Development Economics. The World Bank, 103-125.

${ }^{22}$ See, for example, the case studies of sequencing in Guatemala and Latvia in Das-Gupta, Engelschalk, and Mayville (1999). 


\section{Chapter 9: Simplifying Subnational Taxes}

\section{CHECKLIST OF GOOD PRACTICES}

$\checkmark$ The tax policy division creates an inventory of all taxes and fees paid by taxpayers

$\checkmark$ Nuisance taxes are eliminated and other taxes merged to reduce the compliance burden

$\checkmark$ The subnational tax units piggy-backs on existing taxes to raise revenue and reduce the compliance burden of using a separate tax

$\checkmark$ The tax policy division addresses the causes of tax proliferation

$\checkmark$ The subnational units coordinate their tax policies to reduce barriers to investment such as the free flow of goods and people

$\checkmark$ The subnational tax units reduce their reliance on regulations to fund their budgets

The main purpose of this chapter is to examine how subnational taxes-which include various taxes, licenses, and fees levied on businesses-can be simplified. This is of interest since decentralization is an ongoing process in many countries. Done well, it can improve the provision of public services, both by reducing costs and making such taxes more relevant to the local population.

One important aspect of decentralization is that subnational governments must have some revenue autonomy. This creates, in many cases, additional costs for firms to comply with a new layer of tax-collection activities. Policy makers must, however, be careful to ensure that the greater autonomy and revenue generation by subnational governments does not lead to a dampening of private sector autonomy and initiative. This chapter examines several points: (i) why subnational taxation is warranted; (ii) the options for subnational taxes; (iii) the key problems of subnational taxation from a business perspective; and (iv) how business tax collection can be improved and the compliance burden minimized. 


\subsection{Why Subnational Taxes Are Needed}

Bahl and Martinez-Vazquez note that "despite being one of the most talked about development strategies in the past two decades, decentralization has hardly taken off . . . the average expenditure share of subnational governments in total government . . has barely budged from its 15 percent level in the 1970s" (2006:14) for developing countries. That said, they indicate that the beginning of the 21st century could see a real increase in decentralization and a corresponding increase in the importance of subnational taxes (particularly property taxes). ${ }^{1}$

Martinez-Vazquez and others (2006:21) also write that "if fiscal decentralization is to be a reality, subnational governments must control their own sources of revenue. Subnational governments that lack independent sources of revenue can never truly enjoy fiscal autonomy, because they may be-and probably are-under the financial thumb of the central government."

And so we seek to answer two questions: Which revenue sources can and should be assigned to subnational levels of government? How will these assignments be carried out?

To the extent possible, services the government provides should be financed by user charges and fees or a close substitute (benefit-related taxes). This is both fair and efficient. Among the examples of benefit-related taxes are those levied on motor vehicles and motor fuels, which are used to construct and maintain roads. Such taxes can also be used to reduce congestion, pollution, or both when set to take both the direct value of the service provided to the user and these social costs into account.

Subnational governments must have enough own revenues to finance the services they provide. Each level of government should therefore be assigned taxes that are related to the benefits derived from its spending. This would make the proper assignment of taxes that are related to benefits depend on the assignment of responsibilities. If a subnational government sets and collects its own taxes in a stable legal context, it clearly has a source of revenue, even if such a government must rely for a large part on grants from a higher-level government. It may be considered to have adequate own revenues, provided the grants are determined in an objective way in a stable legal context (constitutional division of powers or law).

Own revenues do not exist, however, if grants are made at the sole discretion of the higher government. Various issues can arise in such a case, including grants allocated on an ad hoc basis, grants paid in an unpredictable fashion, grants paid only

\footnotetext{
1 Fox and Swain (2007) point out that subnational taxation and expenditures can be both efficiency enhancing and efficiency reducing. The first view sees federal arrangements as reducing the size of government through competition, while the second is concerned about inefficient subnational tax policy, in particular through taxation on mobile factors that are too low.
} 
if certain conditions are met, grants paid with delays, or a combination of all these bad practices. Between these extremes lie a variety of arrangements that provide more or less complete subnational ownership of revenues. Tax surcharges collected by higher-level governments might be seen as own revenues if there is no substantial risk that the higher-level government collecting the revenues will not remit them to the subnational government.

Many services that central and subnational governments provide can be described as producing generalized benefits, or benefits that cannot be closely related to the taxation of the beneficiaries. Although generalized benefits may not be conducive to the use of charges and fees, or taxes closely related to benefits, they can be related in a general way to taxes paid. Thus, for example, the general benefits of government spending may be loosely related to individual income or consumption. At the subnational level, if people do not work in the same subnational tax jurisdiction where they live, one must ascertain whether private production or consumption (income earned or income spent) is the better measure of generalized benefits.

If the benefits of public spending are more closely related to the earning than to the spending of income, origin-based taxes on value-added and payroll taxes levied where employment occurs would be superior to destination-based value-added taxes (VAT), retail sales taxes, and residence-based income taxes as a means of financing benefits received.

\subsection{Political Economy of the Proliferation of Subnational Taxation}

Tax complexity results from political tradeoffs, the product of elite bargaining within the political "rules of the game"-for example, the fragmented power structures under Yeltsin's Russia of the 1990s created a system of enormous complexity. By 1997 the tax code already consisted of nearly 200 different taxes, augmented by 1,200 presidential decrees and government orders, 3,000 legislative acts, and 4,000 regulatory acts, while regional governments added more than 100 taxes of their own (Easter 2008).

Fiscal decentralization in assigning local governments a large share of locally generated revenues might promote economic development. The more local officials benefit from local economic activity, the more supportive of business and less corrupt they should be, resulting in higher output. China's rapid growth may be because of its high local retention rates, and Russia's 1990s stagnation due to the central clawback of local revenues. In China, local governments' increasing autonomy has given rise to an explosion of local taxes, fees, fines, and apportionment (Zhu and Krug 2006; Bernstein and Lu 2008). The net effect on output is indeterminate, depending on the broader governance context (Treisman 2006). 
Particular attention should be paid to taxpayer education: information is critical to support reform efforts. Citizens are in general badly informed about the structure, effects, and design of their country's tax system-even unaware of the taxes they themselves pay (Steinmo 1999:194).

\subsection{Options for Subnational Taxes}

An important prerequisite for the exercise of subnational fiscal autonomy is the ability to choose statutory tax rates. ${ }^{2}$ A given tax should be assigned to the lowest level of government that can implement it (or for which it can be implemented) and for which it is not inappropriate. One reason to prefer tax autonomy to its absence is that tax competition among subnational jurisdictions can protect citizens from greedy politicians and bureaucrats. It helps ensure that taxpayers are getting what they pay for-and that the composition and level of government spending is appropriate.

Three main approaches to assigning revenues to subnational governments can be distinguished. These approaches differ in the degree of fiscal autonomy they provide to subnational governments: the ease of compliance and administration, the fairness and neutrality they are likely to produce, and the degree of interjurisdictional redistribution they can accommodate. Fox and Swain (2007:617) point out that "the state tax function can be decomposed into five components: base definition, rate, designation of taxpayers, administration, and revenue ownership." Subnational governments clearly cannot be allowed total discretion in the choice of the taxes they will levy; for example, they should not be allowed to levy import duties on international trade or trade among subnational jurisdictions, or to impose taxes likely to be exported in large part. Excessive subnational latitude in the choice of tax bases and in tax administration (TA) can create unacceptable complexity and administrative burdens, as well as inequities and distortions in the allocation of resources. However, limited or no latitude in setting the rates of one or more significant taxes (significant in terms of revenue) may result in subnational governments, particularly local ones, creating various licenses, fees, permits, and so on that each yield little revenue but add to the compliance burden of businesses.

The three approaches may be summarized below:

\footnotetext{
2 Why statutory and not effective tax rates? Effective tax rates would vary if subnational governments could alter deductions, exemptions, and so on, but this would mean changing the base and not the rates. This would increase the complexity of the system and the compliance costs of firms operating in multiple jurisdictions.
} 


\section{BOX 9.1 The Multiplicity of Local Taxes and Fees in the Republic of Yemen}

In the Republic of Yemen, 55 types of fees and charges are used to finance local authorities. Some (such as the annual district/municipal operating fee) are subdivided into more than 500 categories of business size and activities. According to the law, a similar charge-the professional permit fee-must also be paid at the governorate (provincial) level and is subdivided into 68 different categories. Companies are also required to pay an annual registration fee to the Ministry of Trade and Industry (MTI), a membership fee to the chamber of commerce, various monthly local council support fees (surcharges on utility bills), city improvement fees (surcharges on specific common transactions), and a range of sector-specific regulatory fees. Companies are also subject to the zakat-originally a religious tax (2.5 percent on capital) — which is used as a business operation levy assigned to local authorities.

All of these payments are in addition to the standard taxes (corporate income tax, goods and services tax, property and property transfer taxes, fuel tax, and tax on insurance contracts), as well as earmarked contributions to social, transport, and development funds. In sum, a mediumsized fishing company registered in Aden, for instance, would typically have to pay up to 15 fees and charges plus standard taxes. The same is true for a hotel or construction company located in the capital city of Sana'a.

Source: FIAS desk review of Yemeni legislation.

\subsubsection{Independent subnational legislation and administration}

This provides subnational governments with the most fiscal autonomy. Under this approach, subnational governments choose the taxes they levy, define the tax bases, set the tax rates, and administer the taxes. ${ }^{3}$ Because they are subject only to general constitutional limitations (for example, noninterference with interregional and international commerce) and almost no statutory limitations, subnational governments can do virtually anything they want in these four areas.

Carried to the extreme, this approach is vulnerable to inconsistency, duplication of effort, and excessive complexity of compliance and administration. Inequities and economic distortions can also occur if the tax systems of various subnational governments do not mesh, resulting in gaps or overlaps in taxation. This can be avoided without greatly compromising the fiscal autonomy of subnational governments through intergovernmental agreements among subnational governments or through the imposition of uniform ground rules by a higher level of government; for example, rules governing the definition and division of the corporate income tax base. ${ }^{4}$

\footnotetext{
3 Subnational constitutions or laws may limit any of these, but self-imposed restrictions in the constitutions of subnational governments differ from restrictions imposed from above by law or as part of a national constitution.

4 As used in Canada, for example, to allocate corporate profits between provinces for provincial taxation.
} 


\subsubsection{Subnational surcharges}

This provides a significant degree of the fiscal autonomy of independent subnational legislation and administration. Under this approach, a higher level of government defines the tax base and collects both its own tax and surcharges set by subnational governments. This approach ideally avoids the problems that occur when different subnational jurisdictions define the tax base in conflicting ways, use different apportionment formulas, and administer the tax in different ways.

Because of their power to set surcharge rates, subnational governments retain the most important attribute of fiscal sovereignty in the tax field. One variant of this would be to have subnational governments use the national tax bases to levy their own taxes as opposed to surcharges and to collect them. ${ }^{5}$ This would increase the compliance burden slightly but would also allow (as in the case of progressive income taxes) subnational governments more flexibility. Another variant would be to have the national government collect a tax set on a common base by subnational governments that it does not, itself, levy.

The problem that would arise from such a system would be in providing incentives for the central government to collect a tax that it does not keep and, indeed, of trusting it not to keep the revenues it ostensibly collects for subnational governments. Surcharges should, of course, be limited to that portion of the tax base reasonably deemed to arise in, or be attributed to, the taxing jurisdiction. Subnational surcharges appear, however, to be the most appropriate means of providing subnational governments with their own marginal revenues in countries where administrative resources are scarce.

\subsubsection{Tax sharing}

Under this approach, subnational governments receive fixed fractions of revenues from particular national taxes originating within their boundaries. The sharing rates are usually, but not necessarily, uniform across jurisdictions, though not across taxes. As with surcharges, formulas may be needed to determine the deemed origin of tax revenues, although this may be difficult in many countries because the data needed to share revenues may not exist or may be unreliable.

This approach severely restricts subnational governments' fiscal autonomy for a number of reasons. Individual subnational governments have autonomy over how to spend a given amount of revenue, but not the power to alter the amount of revenue they receive from shared taxes. They therefore cannot control the level of public spending. All subnational governments, acting as a group, can attempt to influence their share of revenues from these taxes or may even have some legal say, as in the German system,

\footnotetext{
5 As done in Canada since 2000, when provincial surcharges on the federal personal income tax were replaced by provincial income taxes on the federal definition of taxable income in nine provinces.
} 
where the upper house of the two-tiered national parliament is made up of state delegations who vote according to the instructions from their governments.

From the viewpoint of subnational fiscal sovereignty, the choice of rates is what allows subnational governments to choose the level of public services while minimizing the compliance costs associated with collecting the required revenues. This attribute is lost here. Indeed, if it were not for the relationship between the origin of the tax revenue and the amount received, this would be akin to a transfer formula with the source of transfer linked to a specific tax.

\subsubsection{Mixed approach-delegated administration of taxes}

Between the option of national government collecting surcharges and providing funds to subnational jurisdictions and the option of the subnational jurisdiction setting both the base and rate is the option of the subnational jurisdiction only administering the tax while the rate and the base are set by the highest level of government. The advantage for the subnational jurisdiction is that it keeps the taxes it collects. Examples are the personal income tax in Nigeria and the central sales tax in India. In the case of Nigeria, however, this has resulted in difficulty administering the Income Tax because corporations are governed by the federal revenue authority (FIRS) and businesses owned by individuals are governed at state level. As sharing information between federal and state level is essential for the proper administration of the tax, this has become a major problem for the implementation of the personal income tax. For example, it has been extremely difficult for the federal revenue service and the states to accept the use of a common taxpayer ID number.

\subsection{Compliance Issues}

The choices presented above affect businesses' costs to comply with taxes and the overall burden of various tax and regulatory instruments in a variety of ways.

Fox and Swain write that "as a general proposition, administrative and compliance costs would probably be lower if all taxes were administered nationally" (p. 615). Compliance costs would be lower as a result of dealing with a single revenue authority and using a single-tax structure. Administrative costs would also drop if economies of scale (more returns processed) and economies of scope (more taxes collected) exist. This, however, reduces the tax autonomy of subnational governments and puts their revenue collection in the hands of a central agency that may not have much interest in doing this well, preferring instead to concentrate on national taxes.

From the foregoing, it is clear, therefore, that tax sharing would appear to produce the least compliance burden, followed by tax surcharges and finally by tax independence. One should note, however, that this neglects the substitution between 
taxation and other revenue generating activities (licenses, fees, permits) that subnational governments can engage in.

It is useful to examine whether there is any evidence to back the claim by Fox and Swain. It is interesting first to note that quite a few studies on the investment climate or on taxes' impact on investment do not address such issues. ${ }^{6}$ From an examination of 19 studies of business compliance costs, Vaillancourt and others (2007) note the following:

- A study of the Canadian (predecessor of the current Canadian Goods and Services Tax, GST) federal sales tax (Brown and Vaillancourt 1986) reports that an increase in the number of tax rates faced by a taxpayer increases compliance costs.

- A study of Canadian federal corporate income tax (Erard 1997) shows that compliance costs increase with the number of provinces in which the federal and provincial corporate income taxes (CITs) are paid.

- A study of all Canadian taxes (CFIB 2005) reports that differences among provincial rules increases compliance costs.

- Edwards (2004) argues for the repeal of U.S. state corporate income taxes, noting that they are twice as costly to collect as the federal corporate income taxes.

It appears, therefore, that there is some evidence that the use of subnational taxes increases compliance costs. It is also a well-established finding in the empirical literature on various taxes in many countries (Vaillancourt 1987, 1999; Vaillancourt and others 2007) that taxes on business are higher in percentage terms with respect to indicators such as taxes collected, gross turnover or sales, and wages and salary bills. This means smaller businesses that are taxed on the basis of these indicators face a higher tax burden than larger ones even if, in absolute terms, larger firms pay more. Table 9.1 presents evidence from three federal countries on the relationship between size and compliance costs. It shows important decreases in the costs per employee, income, or sales when the size of the business increases; differences in the importance of such decreases reflect in part the reference points used.

\footnotetext{
6 Two recent OECD studies (2006, 2007) on the investment climate in general do not explicitly address subnational taxation. Hallward-Driemeier and others (2003) use evidence from Chinese firms in five large cities. They note that regional Chinese governments have been given different degrees of discretion in setting regional economic policies, including subnational taxation; "the central and regional tax arrangements were negotiated province by province" (p. 4). Unfortunately, their empirical work does not include subnational taxes as an indicator of investment climate. Another paper, by Aterido and others (2007), finds-after examining data for 70,000 enterprises from 107 countries-that the impact of the investment climate varies across firm size and that different variables have different impacts by size; for example, business regulations affect micro firms more than SMEs, while the reverse holds for corruption. They do not have tax variables in their model, but this raises the question of differentiated impacts of subnational taxation by size of firm.
} 
TABLE 9.1 Ratio of compliance cost of largest to smallest business (nine studies, three federal countries)

\begin{tabular}{|c|c|c|c|c|c|c|}
\hline $\begin{array}{c}\text { Country/ } \\
\text { tax }\end{array}$ & Ca Sales & Ca PIT & Ca All taxes & $\begin{array}{c}\text { Ca All } \\
\text { taxes }\end{array}$ & Au PAYE & U.S. CIT \\
\hline $\begin{array}{c}\text { Indicator } \\
\text { costs }\end{array}$ & Cost/sales & $\begin{array}{c}\text { Cost/gross } \\
\text { income }\end{array}$ & $\begin{array}{c}\text { Cost/ } \\
\text { Income }\end{array}$ & $\begin{array}{c}\text { \$ per } \\
\text { employee }\end{array}$ & Cost/Income & Cost/Sales \\
\hline Smallest & First third & First third & $<50,000 \$$ & $0-4$ & $<500,000 \$$ & $<25,000 \$$ \\
\hline Largest & Last third & Last third & $2-5,000,000$ & $50-499$ & $5-10,000,000$ & $>5,000,000$ \\
\hline $\begin{array}{c}\text { Ratio } \\
\text { largest/ } \\
\text { smallest }\end{array}$ & $0.12 / 0.055$ & $3.36 / 0.64$ & $5.7 / 0.2$ & $3,313 / 423$ & $4 / 0.4$ & $0.46 / 0.05$ \\
\hline
\end{tabular}

Source: Vaillancourt and others 2007, modified by author.

Note: $\mathrm{Au}=$ Australia; $\mathrm{Ca}=\mathrm{C}$ anada; U.S. = United States of America.

$\mathrm{CIT}=$ Corporate Income Tax; PIT = Personal Income Tax; PAYE = Pay As You Earn

\subsection{Which Subnational Taxes Should Be Levied}

To guide subnational governments, one must provide specific feedback on each tax to be potentially levied. This is provided in table 9.2, which presents a classic set of tax assignments among central/federal, subnational/regional, and local governments put forward by Shah (1994). The following points are worth noting:

- Some of the assignments hold true, irrespective of the responsibilities of governments. For instance, natural resource rent tax, customs revenues, and the corporate tax are usually assigned at the central level.

- Some of the tax assignments are dependent on the assignment of responsibilities. For example, the assignment of "sin" taxes should, in part, reflect who has to provide the health, police, and social services associated with the consumption of each "bad" item.

- The collection arrangements put forward are pro-central government. It is conceivable to have subnational governments collect central taxes as do the German Landers, Swiss cantons, or Québec in Canada (GST).

- Finally, the literature has changed since 1994 and it is now agreed that subnational VATs are a plausible outcome (Bird 1999).

- This kind of assignment table is prepared without taking into account the costs faced by businesses should a tax be given to one level or another of government.

\subsection{Assigning the Right Subnational Taxes}

Three general points are worth noting before presenting specific tax choices. 
TABLE 9.2 Possible tax assignment-three responsibilities

\begin{tabular}{|c|c|c|c|c|}
\hline \multirow[b]{2}{*}{ Type of $\operatorname{tax}$} & \multicolumn{2}{|c|}{ Determination of } & \multirow[b]{2}{*}{$\begin{array}{l}\text { Collection and } \\
\text { administration }\end{array}$} & \multirow[b]{2}{*}{ Comments } \\
\hline & Base & Rate & & \\
\hline Customs & $\mathrm{F}$ & $\mathrm{F}$ & $\mathrm{F}$ & International trade taxes \\
\hline Corporate income & $\mathrm{F}$ & $\mathrm{F}$ & $\mathrm{F}$ & $\begin{array}{l}\text { Mobile factor, stabilization } \\
\text { tool }\end{array}$ \\
\hline \multicolumn{5}{|l|}{ Resource taxes } \\
\hline $\begin{array}{l}\text { Resource rent (profits, } \\
\text { income) tax }\end{array}$ & $\mathrm{F}$ & $\mathrm{F}$ & $\mathrm{F}$ & $\begin{array}{l}\text { Highly unequally } \\
\text { distributed tax bases }\end{array}$ \\
\hline \multicolumn{5}{|c|}{ Royalties, fees, charges, severance taxes } \\
\hline $\begin{array}{l}\text { Production, output, and } \\
\text { property taxes }\end{array}$ & $S, L$ & $S, L$ & $S, L$ & $\begin{array}{l}\text { Benefit taxes/charges for } \\
\text { state and/or local services }\end{array}$ \\
\hline Conservation charges & $S, L$ & $S, L$ & $S, L$ & $\begin{array}{l}\text { To preserve the local } \\
\text { environment }\end{array}$ \\
\hline Personal income & $\mathrm{F}$ & $F, S, L$ & $\mathrm{~F}$ & $\begin{array}{l}\text { Redistributive, mobile } \\
\text { factor; stabilization tool }\end{array}$ \\
\hline $\begin{array}{l}\text { Wealth taxes (taxes on } \\
\text { capital wealth, wealth } \\
\text { transfers, inheritances, } \\
\text { and bequests) }\end{array}$ & $\mathrm{F}$ & $\mathrm{F}, \mathrm{S}$ & $\mathrm{F}$ & Redistributive \\
\hline Payroll taxes & $\mathrm{F}, \mathrm{S}$ & $\mathrm{F}, \mathrm{S}$ & $\mathrm{F}, \mathrm{S}$ & $\begin{array}{l}\text { Benefit charge, for example, } \\
\text { social security coverage }\end{array}$ \\
\hline $\begin{array}{l}\text { Multistage sales taxes } \\
\text { (value-added tax) }\end{array}$ & $\mathrm{F}$ & $\mathrm{F}$ & $\mathrm{F}$ & $\begin{array}{l}\text { Border tax adjustments } \\
\text { possible under federal } \\
\text { assignments; potential } \\
\text { stabilization tools }\end{array}$ \\
\hline \multicolumn{5}{|c|}{ Single-stage sales taxes (manufacturer, wholesale, retail) } \\
\hline Less centralized choice & $\mathrm{S}$ & $S, L$ & $S, L$ & Higher compliance cost \\
\hline More centralized choice & $\mathrm{F}$ & $S$ & $\mathrm{~F}$ & $\begin{array}{l}\text { Harmonized, lower } \\
\text { compliance cost }\end{array}$ \\
\hline \multicolumn{5}{|l|}{ Sin taxes } \\
\hline $\begin{array}{l}\text { Excises on alcohol and } \\
\text { tobacco }\end{array}$ & $\mathrm{F}$ & $\mathrm{F}$ & $\mathrm{F}$ & $\begin{array}{l}\text { Health care shared } \\
\text { responsibility }\end{array}$ \\
\hline Betting, gambling & $S, L$ & $S, L$ & $S, L$ & State and local responsibility \\
\hline Lotteries & $S, L$ & $S, L$ & $S, L$ & State and local responsibility \\
\hline Racetracks & $S, L$ & $S, L$ & $S, L$ & State and local responsibility \\
\hline
\end{tabular}


TABLE 9.2 (continued)

\begin{tabular}{|c|c|c|c|c|}
\hline \multirow[b]{2}{*}{ Type of $\operatorname{tax}$} & \multicolumn{2}{|c|}{ Determination of } & \multirow[b]{2}{*}{$\begin{array}{l}\text { Collection and } \\
\text { administration }\end{array}$} & \multirow[b]{2}{*}{ Comments } \\
\hline & Base & Rate & & \\
\hline \multicolumn{5}{|c|}{ Taxation of "bads" (negative externalities) } \\
\hline Carbon & $\mathrm{F}$ & $\mathrm{F}$ & $\mathrm{F}$ & $\begin{array}{l}\text { To combat global and } \\
\text { national pollution }\end{array}$ \\
\hline $\begin{array}{l}\text { British Thermal Unit } \\
\text { (BTU) taxes }\end{array}$ & $F, S, L$ & $F, S, L$ & $F, S, L$ & $\begin{array}{l}\text { Pollution impact may be } \\
\text { national, regional, or local }\end{array}$ \\
\hline Motor fuels & $F, S, L$ & $F, S, L$ & $F, S, L$ & $\begin{array}{l}\text { Tolls on federal, provincial, } \\
\text { and local roads }\end{array}$ \\
\hline Effluent charges & $F, S, L$ & $F, S, L$ & $F, S, L$ & $\begin{array}{l}\text { To deal with interstate, } \\
\text { intermunicipal, or local } \\
\text { pollution issues }\end{array}$ \\
\hline Congestion tolls & $F, S, L$ & $F, S, L$ & $F, S, L$ & $\begin{array}{l}\text { Tolls on federal, provincial, } \\
\text { and local roads }\end{array}$ \\
\hline Parking fees & L & L & L & To control local congestion \\
\hline \multicolumn{5}{|l|}{ Motor vehicles } \\
\hline $\begin{array}{l}\text { Registration, transfer } \\
\text { taxes, and annual fees }\end{array}$ & S & $S$ & $S$ & State responsibility \\
\hline Drivers' licenses and fees & S & S & S & State responsibility \\
\hline \multicolumn{5}{|l|}{ Other } \\
\hline Business taxes & S & S & $S$ & Benefit tax \\
\hline Excises & $S, L$ & $S, L$ & $S, L$ & Residence-based taxes \\
\hline Property & s & L & L & $\begin{array}{l}\text { Completely immobile } \\
\text { factor, benefit tax }\end{array}$ \\
\hline Land & S & L & L & $\begin{array}{l}\text { Completely immobile } \\
\text { factor, benefit tax }\end{array}$ \\
\hline Frontage, betterment & $S, L$ & L & $\mathrm{L}$ & Cost recovery \\
\hline Poll tax & $F, S, L$ & $F, S, L$ & $F, S, L$ & Payment for services \\
\hline User charges & $F, S, L$ & $F, S, L$ & $F, S, L$ & Payment for services \\
\hline
\end{tabular}

Source: Shah 1994

Note: $\mathrm{F}=$ federal responsibility; $\mathrm{S}=$ state or provincial responsibility; $\mathrm{L}=$ local responsibility. 


\section{BOX 9.2 Proliferation of Taxes in Nigerian States}

The state and local governments of Nigeria's four major states-Kano, Kaduna, Lagos, and CrossRiver-have imposed a number of taxes on businesses. According to businesses in these states, proliferation of taxes represents one of their biggest problems. Foreign Investment Advisory Service (FIAS) work in Nigeria has found that the Lagos local government levies over 126 different fees and licenses, and the local government in Kaduna state has 147 different fees and licenses, including a burial fee levied on the number of corpses.

The problem of tax proliferation arose primarily because: (i) state and local governments had limited resources to fund their public spending; (ii) vague definitions within the primary law gave them the power to tax different tax bases; (iii) innovative taxes were created primarily by private tax collectors, also known as "consultants"; and (iv) taxes were used by corrupt officials as a guise to extort from individuals and business.

Nigeria has a federal structure of government, and tax bases are assigned to the various levels of government. Corporate taxes and VAT are collected and retained by the federal government, and while the personal income tax base is under the federal government, it is collected and retained by the state government. Oil revenue goes directly to the federal government. While federal taxes are reallocated to the different states, the limited tax bases for the states have reduced their capacity to raise revenues. This motivates them to look for new tax bases.

The taxing power of the states depends on the authority given to them by the federal law called Decree 21. FIAS found that imprecise definitions for the different tax bases implied that state and local governments could "invent" new taxes that had only an indirect connection to the intention of the decree. For example, while property taxes have been given to the local governments, and are intended to tax immovable property, this right has been used by them to tax all kind of property, including household property.

These kinds of innovative taxes have, in many cases, resulted in multiple taxation of the same tax base, prohibited by the constitution, which allocates the tax base exclusively to the different levels of government. For example, while cellular phone installations, especially cell phone towers (and the requisite regulations), fall under federal jurisdictions, states have used their regulatory laws to impose a fee on the installation of telecom towers, claiming that they had the power to do so to ensure safety of the citizens. Similarly, states are now planning to impose a sales tax even while a federal VAT is already in force.

- Subnational taxes are an important source of revenue for subnational governments, and the specific answer as to what tax should be used by subnational governments will depend on the specifics of each country. ${ }^{7}$

- Various central government interventions are possible, with the main differences being the degree of coercion employed: Do they require the use of the federal base or do they make it available for use by the states; do they carry out their own collection activities, or does the federal government carry

\footnotetext{
Gonçalves de Mendoça (2004) reminds us in the context of the use of the state-level VAT by Brazilian states to attract investments (the so-called fiscal war) that "perhaps it would be better to discuss subnational taxation in the context of a broader federative reform considering issues such as regional development, the attributions that should be assigned to the states and the suitable sources of revenues to finance them." See also McClure (2001).
} 


\section{BOX 9.2 (continued)}

The limited funds to run their respective governments is also leading state and local governments to tax through regulations. A number of regulations have been created with the primary aim of collecting revenue-not regulating. The example above of cellular telephone towers is a prime example. Federal government regulations should, in fact, ensure that towers are installed safely; however, state governments have used this ground to charge a fee to ensure safety. Interesting examples of such fees include those on the erection of tombstones, on mobile advertisements, and on musicians. Fees for mobile advertisements are one of the most despised levies and are charged on any vehicle, even those that do not carry mobile advertisement. The grounds for this are that the person driving the car is a mobile advertisement for the company he represents.

The multiplicity of taxes sometimes borders on extortion and is levied on dubious grounds with limited legitimacy. The state and local governments depend on private tax collectors called consultants. While the use of consultants for tax collections has been banned, and their role limited, ostensibly, to information gathering, in practice, they are used widely by TAs. As a result, there is a strong lobby whose goal is to widen the tax base and "invent" new taxes to keep itself in business. The budgeting of these taxes is very nontransparent and it is unclear if the taxes collected actually reach the treasury or are being pocketed by unscrupulous government officials.

One lesson to learn from Nigeria is that subnational taxes can become a major issue for business when state and local governments under financial strain create multiple taxes to sustain their delivery of public goods. The limited transparency of these taxes can induce corrupt government officials to create new taxes with the goal of pocketing them. Another lesson is that the reliance on the private sector for tax collection could lead to unintended consequences that have an adverse impact on the investment climate. The solution includes (i) greater coordination among levels of government to understand the overall tax burden on business; (ii) details, in one place, of all taxes imposed on business and their legal justification; (iii) consolidation, to the degree possible, of collection of various taxes so as to reduce the burden of compliance on business; and (iv) limits on the role of the private sector in TA to back-office operations.

Source: FIAS Report (2008), Nigeria—Sector Study of Effective Tax Burden.

them out; does the federal government cooperate more in cross-checking tax information when the federal base is used than when it is not? ${ }^{8}$

One possibility, not frequently explored, is a national tax agency that is jointly owned, or at least supervised, by both the central and subnational governments. This is perhaps an interesting way forward for tax authorities to accompany decentralization. Indeed, in a debate ongoing in Canada on how to replace the 13 (10 provinces and 3 territories) Securities and Exchange Commissions (SECs), the proposed structure

\footnotetext{
8 See Fox and Swain (2007). An interesting point raised by them is that the stability of the federal tax base will matter to the other users of that base; this is an issue in the HST agreement in Canada. That agreement saw three of the smaller and less prosperous provinces surrender their autonomy in baseand rate-setting to a federal-provincial compact. It was also raised in that country when the federal government substantially modified its definition of taxable income in 1972 .
} 
is not a central government SEC but a national SEC that would be governed by a board appointed by the various governments. One finds in some countries (Democratic Republic of Congo, for example) arrangements that centralize all the revenue and expenditure in the treasury account at the central bank with the Treasury acting as a distributor of tax revenues between levels of government. While shared taxes and the distribution key may be wrong ( 40 percent of all national taxes on a derivation principle, including custom duties, unduly enriches the main custom points of Matadi and Kinshasa), the fact that this mechanism has been working since the early $2000 \mathrm{~s}$ (with a lower sharing percentage) is worth noting.

Subnational taxes, imposed mainly on local residents, should be selected to minimize administrative and compliance costs and should not impact the efficiency of the internal common market. Taxes should be allocated across levels of government in such a way that they do not impede the functioning of the internal markets with respect to capital flows, labor mobility, and trade in goods and services?

\subsection{How Best to Set Subnational Taxes}

- User fees, both direct and strongly linked to services delivered by the subnational government or used by the taxpayer, should be exploited as much as possible. In particular, parking fees, entry fees into congested urban areas, and fuel taxes should be widely used, at least at the level responsible for providing roads and public transit. Benefit taxes should also be used as fully as possible. This

\footnotetext{
9 In this respect, when all is said and done, who really gets the tax revenues trumps the other issues from the perspective of the subnational governments. Various arrangements on this point are possible, but in the French tradition of many African countries, one finds the principle and practice of a single treasury (also found in France). This means that all tax revenues are deposited with one treasurer who acts for both the central and subnational governments and who is an employee of the central government. Thus, revenues collected at the subnational levels are recorded in the books of subnational governments. But the relevant amounts are not under the control of that level of government and may be appropriated by the central government for its own purposes. In practice, this is often the case in francophone Africa and results in municipal governments levying various nontax fees such as market fees, parking fees, and so on that are not treated as taxes and are collected by municipal employees, with the cash remaining in their hands. For example, only a percentage of the Cameroonian "centimes additionnels" - a 10 percent surcharge on all national taxes-was actually turned over to the communes in the last half of the 1990s. This explains in part the reluctance of subnational governments to replace old, inefficient taxes (such as octroi and other taxes on the physical quantities of goods that move between jurisdictions) that they collect, and whose revenues flow to their treasury, with new, modern taxes such as VATs, which are nondistortionary, have a broader base of services included, and are collected by central governments who promise to hand over revenues. When Morocco switched to a VAT in 1988, municipalities were guaranteed by law 30 percent of the VAT revenues. This promise was kept over various years by defining as municipal responsibilities central government activities such as rural electrification or the construction of school buildings. And when Pakistan abolished provincial octroi, replacing them with transfers to provinces funded by an increase in the rate of the VAT, one issue that quickly arose is that the rate of increase in such transfers in the case of Sindh was smaller than the expected increase in octroi revenues. Hence, it is not surprising to see Argentinean provinces prefer to retain their old-fashioned taxes on transactions rather than accept their disappearance and replacement by a share of the national VAT.
} 
is recommended since, in general, subnational governments provide services often more akin to private goods and services (education, firefighting, libraries) than to public goods and services whose benefits are more diffuse.

- There should be no taxes—octroi or "ristournes"-levied either when products leave an area (levies on the movement of natural resources such as wood in Madagascar) or when products cross a subnational boundary such as that of Indian states. These taxes violate national efficiency. If such taxes exist, they should be replaced by a subnational business levy, if levied by the states, or by an increase in the property tax on nonresidential properties, if levied by municipalities.

- The number of tax instruments should be limited. James and others (2007) note that nonsmart and smart taxation have differing characteristics. Of relevance here is that nonsmart taxation uses many tax instruments, each raising little revenue and with high compliance costs while smart taxation uses few tax instruments, broadly applied. They attribute this, in part, to unclear taxation powers at the subnational level that leads to a plethora of small taxes. In Morocco, for example, a bar may face a property tax, a patente based on the number of seats and type of drinks served, a tax based on early opening or late closing hours, a tax on its signs (size, lighted or not), a tax on occupying public space (terrace), a tax on an overhang over the public roadway. But bigger bars serving alcohol all night in a given location will be worth more than smaller bars serving fruit juices a few hours a day in the same location. This greater value will translate into higher property values-either directly or through higher rental income-for the owner of the rented bar. This can be captured by property taxes or their equivalent on rental income, effectively paid or imputed for owner-occupied buildings.

- One should use mainly property-based taxation for municipalities and subnational sales (general, preferably, but excises may be appropriate) taxes for regional governments (Bird 2000). This is because subnational taxation of personal income is unlikely and also because payroll taxation in the region of work and by region of residence (appropriate to public provision of services consumed in the place of residence) is hard to implement.

With respect to sales taxes, surcharges on the VAT are a possibility-but tiered transaction taxes, as in Madagascar, which until 2008 had three types of such taxes, ${ }^{10}$ may also be a solution. With respect to property taxes, recent land titling in Madagascar provides certainty of ownership. The increase in the tax base for local governments as a result was a win-win. ${ }^{11}$ A similar outcome resulted

\footnotetext{
${ }^{10}$ As when sales are less than 20,000,000 Ariari allocated between communes on the derivation principle; TST for businesses with sales of 20-50 million allocated between subnational governments on a formula basis and the national VAT for larger businesses.

${ }^{11}$ http://www.cirad.mg/fr/anx/fonc060202.php.
} 
from the Bhoomi ${ }^{12}$ land registration system in Karnataka, India. Similarly, Lund and Skinner (2005) discuss various procedures implemented in Durban, South Africa. They note the desire among many street vendors for a license system that gives them a form of ownership over their selling site and the introduction of a "system of decentralized registration and pay points, both of which serve to reduce transaction costs for poorer traders" (p. 11). Hence, taxation with strengthening ownership or usage right may be an option worth pursuing.

- One should be aware that for many business taxes, smaller taxpayers are more relevant to subnational governments than larger ones. This is accentuated in countries where a special unit in the national ministry of finance or revenue is in charge of collecting taxes from large businesses. While this is done to increase the yield of the major national taxes such as corporate income tax and VAT, if some subnational taxes are collected centrally and not remitted to the appropriate local authorities this may cause problems. For example, in Tunisia, a location-based quasi-value-added tax should be paid according to where the activity is carried out, but if the relevant tax is paid by the head office in Tunis, it may well be all credited to the Tunis municipality with no onward reallocation. Other local authorities may then, from their point of view, seek rightfully to claim taxes, which would-from a business standpoint-be seen as double taxation and harassment. Clear allocation rules and transparency in recording and sharing information are, therefore, very important.

Insofar as some taxes are set as a lump sum or with both a fixed and variable part (as is often the case with patente-type taxes), they will represent a larger share of costs for smaller businesses. Informal firms are more likely also to attract the attention of subnational governments (an example would be sellers in markets or small buses at bus stations paying daily usage fees).

One interesting aspect of such revenue streams for municipal authorities is that they can be farmed out in some countries to private tax collectors. These collectors agree to pay a fixed amount on a weekly, monthly, or quarterly basis (for a percentage of collections), thereby guaranteeing a steady revenue stream to the local government whatever the amount they effectively collect. For example, in Tanzania, Produce Cess, a turnover tax on agricultural output, is collected through private contractors in many districts. Given the incentives, such collectors will seek to collect as much as they can and may therefore be overzealous in their interpretation of tax rules and tax rates. On the other hand, they may be willing to extend short-term credit to address liquidity difficulties faced by taxpayers. Given the evidence on the regressivity with respect to size of business of compliance costs, it is not incorrect to have a lower tax burden for smaller businesses to compensate them for this.

\footnotetext{
12 http://bhoomi.kar.nic.in/Bhoomi/Benefits.htm.
} 
There are a number of potential difficulties that arise from the above-described regimes. Engelschak (2005) reviews the use of presumptive taxation in transition economies. Such taxation can be carried out using a turnover tax, a presumptive tax based on indicators (such as floor space of establishment), or a patente with a fixed amount usually set through reference to a table listing detailed activities. He raises a key point by noting that the impact of a presumptive taxation system on both administrative and compliance costs will depend on the number of taxes the presumptive tax replaces. If only a few (major) taxes are covered, this will have little impact. Since the design of such systems is difficult, tax authorities often change their parameters, creating instability from the perspective of the taxpayer. Finally, where revenue yields are low and represent a negligible share of tax collection, there is a risk of collection and compliance costs exceeding the amount of tax collected. ${ }^{13}$

\subsection{Conclusion}

Subnational governments have an important role to play in the provision of public services in all countries and require some types of their own revenues to do this correctly. Various authors, such as Boadway and others (1994), indicate a continuum of choices: from sharing a central tax whose parameters are set centrally and allowing subnational governments to levy a surcharge on central taxes collected by the central government; to allowing them to levy their own taxes on this base; to co-occupying a tax field.

However a government decides to proceed, such taxes must be chosen and designed to minimize the compliance and efficiency costs they create. To do so, one should not use levies on interregional trade, but rather use user fees and charges and broad-based taxes_-assessed using national tax bases, but with rates set by subnational governments. Collection should be carried out by the most efficient level of government with respect to each specific tax. To reduce the costs for SMEs of tax compliance, possible measures include increasing thresholds and thus reducing the frequency of filings and simplifying rules. In making choices, one should take into account, among other factors:

- Extent of the likely reduction in unproductive tax compliance activity and the cost-benefit efficiency of each measure

- Impact on both economic efficiency and equity

- Fiscal cost, including revenue impacts and the administrative costs of implementing, maintaining, and monitoring specific measures

- Administrative feasibility and short-term capacity constraints

\footnotetext{
${ }^{13}$ Engelschak (2005:27).
} 
- Minimizing any increased potential for tax avoidance and erosion of the tax base

- Potential for introducing undesirable or unintended bias or distortions into economic decision making (government of New Zealand 2007:5).

Whatever changes are implemented, their impact should be monitored, using both direct and indirect indicators. Direct indicators can include the amount spent on items such as external tax advisers and internal time spent complying with tax obligations as well as nonmonetary costs such as stress and unpaid time. Indirect measures can include proxy measures of the complexity of compliance processes (such as taxpayer filing error rates) and the quality of services (for example, user satisfaction with the legislation). One interesting indicator suggested by Stern and Barbour (2005) is the marginal effective tax rate (METR) to compare the tax rates faced under small business taxation and regular taxation in three countries. They note that "full registration sometimes confers a commercial credibility or legitimacy in dealing with third parties, which some firms may consider to be worth more than the compliance costs associated with registration, as well as the ability to bid for government contracts" (p. 7).

\section{Further Guidance}

- Laurent Corthay. 2009. "Local Taxes, Regulations, and the Business Environment: Finding the Right Balance." CIC, The World Bank Group. 


\section{APPENDIX 9A}

\section{Subnational Taxation-An Example from Côte d'Ivoire}

Côte d'Ivoire provides an example of current subnational tax arrangements for which we have both recent information and an assessment (November 2007). The country has two layers of subnational governments: municipalities (communes) and, more recently (created in 2003), districts (urbains/départements). The first cover about 60 percent of the population and the second all of the population. We will focus on the municipalities, as the districts have minimal tax revenue except for Abidjan, the economic capital, which has a metropolitan-type government quite different from all others. The revenues of municipalities for 2005 comprise national taxes (37 percent of total revenues) own taxes and fees (23 percent), transfers (20 percent), and miscellaneous revenues (20 percent) (Vaillancourt 2008). The first two items are the focus of our discussion.

National taxes. The main taxes under this heading are the property tax on buildings ( 15 percent rate on rental value), the property tax on unbuilt land (1.5 percent rate on property value), and a business tax (two parts, the first being a tax on gross revenue from the previous year- 0.5 percent - and the second part being a current year rental value of business premises-18.5 percent). These taxes are levied and collected by the central government.

There is a synthetic tax for small businesses that replaces the personal income tax (general revenue tax, IGR), the corporate income tax, the VAT, and the patente. Note that this does not cover all the national taxes collected for municipalities and none of their own taxes and fees.

Own taxes and fees. ${ }^{14}$ Examining a sample of public accounts for 10 municipalities, one finds that the major own source of tax revenue for 2005 (50 percent of such revenues) is the lump sum tax on small merchants, that is, merchants not

\footnotetext{
${ }^{14}$ Information in this section draws heavily on Mobilisation des resources fiscales locales: État des lieux, Traoré Bakari Consulting November 2007.
} 
subject to the patente or synthetic tax. This tax can be a source of important problems for small businesses since the law setting it up does not define what a small merchant is but provides a list. In addition, as the law dates back to 1961, it is completely unadapted to new activities (such as internet cafes). As a result, it is reported that some municipalities have created taxes on unenumerated activities or modified rates on enumerated activities. Neither of these fiscal activities have a sound legal foundation.

The second most important source of own tax revenues is fees for the use of the public domain such as those paid by owners of cafes and restaurants, but this is much less important at about 12 percent of revenues from own taxes and fees. This is an easily observable activity for tax authorities, but one wonders why it cannot be captured by the tax on buildings; one answer is that these fees are collected directly by the municipalities and not by the central government and thus, while creating both a need for more tax collectors and an additional compliance burden on businesses, they generate more certain revenues for municipalities.

Other interesting taxes to examine are the tax on equipped commercial rentals (1-5 percent of monthly rate, depending on usage rate) and the tax on fuel pumps. The first one turns out to be very hard to collect since it requires an estimation of the effective usage rate of the rented facilities; but it is also a very demanding tax from a compliance perspective. It yields less than 1 percent of own tax and fee revenues, so it is a good example of how abolishing it is a win-win for both taxpayers and municipalities, at a low revenue cost. The fuel pump tax increases with the size of the municipal population, from 2,500FCFA/monthly in a municipality of less than 20,000 inhabitants to $10,000 \mathrm{FCFA} /$ monthly in a municipality of more than 200,000 inhabitants. This creates an incentive to locate fuel pumps in smaller communes at the border of the larger ones, something one observes in part of Abidjan; this may well result in suboptimal spatial allocation of resources.

Finally, while we concentrated on municipalities, it is interesting to note that following interviews with six districts (four départements and two urban districts), Traoré Bakari Consulting observes the following:

- Lack of tax initiatives in three of four départements that thus have only subsidies and shared national taxes as revenues;

- Desire by one general council in a département (Daloa) to levy taxes that are not under its jurisdiction, such as taxing mortuaries, ambulatory merchants, and agricultural output (cacao, coffee, maize). The position of that council is that the central government should let departments levy taxes adapted to "local reality." While dynamism is probably preferable to 
passivity, it needs to occur within the proper legal framework. Hence, their introduction in late 2006 of a set of parking fees on trucks, buses, and taxis is clearly without legal foundation. The tax is akin, in the case of trucks, to a levy on the export of natural resources from the départment.

- Difficulties in the Abidjan district of shifting tax bases from the communes to the district. The taxation of advertising banners was shifted in 2003 to the urban districts, but some communes refuse to recognize it; this means that businesses may be approached by tax collectors from both entities and required to pay the tax twice-or see their banner removed.

The use of taxes with little or no legal foundation or of taxes with very little yield and complex tax bases is not, in the experience of this author, confined to Côte d'Ivoire. ${ }^{15}$

\footnotetext{
15 One behavior observed in both Cameroon and Democratic Republic of Congo in the early 2000s was the decision of local or regional officials to continue levying taxes that had been formally abolished since both they and taxpayers knew how to handle them (or how to set the appropriate side payment!).
} 



\section{Chapter 10: Taxpayer Education and Assistance}

\section{CHECKLIST OF GOOD PRACTICES}

$\checkmark$ The tax administration (TA) has dedicated tax education and assistance departments

$\checkmark$ The TA maps out all the stakeholders who interface either directly or indirectly with the tax system

$\checkmark$ The TA has a communication strategy to guide tax payer outreach

$\checkmark$ The TA adjusts its outreach depending on the type of tax and taxpayer

$\checkmark$ Tax education and assistance cover all taxes that taxpayers pay

$\checkmark$ The TA interacts with other ministries, departments, and agencies (MDAs) and local governments that levy taxes to help devise a communication and assistance strategy

$\checkmark$ The TA uses multiple media to reach taxpayers

$\checkmark$ The TA uses private sector bodies, such as professional and business associations, for taxpayer education and assistance

$\checkmark$ The TA also reaches out to potential taxpayers, including youth and children

$\checkmark$ The TA addresses questions of tax culture and the role of taxes in nation building

$\checkmark$ The TA regularly asks for feedback from the public about the effectiveness of its education and assistance

$\checkmark$ Taxpayer education and assistance include taxpayer complaints

The goal of an effective tax education and compliance improvement strategy is to reach taxpayers and potential taxpayers through the most convenient medium, deliver a change-inducing message, and provide assistance in the best manner possible at the right time.

Most taxpayers around the world have a negative impression of the process of paying taxes. This is often exacerbated by lack of information or by the complexities of tax calculation, payment methods, appeal procedures and-more fundamentallyby the lack of information on how the taxes paid benefit the taxpayer or otherwise contribute to the public good. In many cases-even when the procedures, laws, and 
how they are applied are written and available-fully transparent compliance by the tax administration (TA) is the exception rather than the rule. This ambiguity and lack of knowledge can drive taxpayers to avoid the tax system altogether, if they can do so without recourse. Where this is not an option, taxpayers often feel compelled to use intermediaries or professionals to deal with even routine tax matters, thereby raising the cost of compliance.

The goals of a sound taxpayer engagement and assistance policy are to help taxpayers easily comply with the tax laws by: (i) simplifying the computation of their tax liability; (ii) simplifying filing and payment procedures; (iii) educating them about the tax-return review process; and (iv) educating them about appeal options and procedures.

Taxpayer education should also include information that preserves or strengthens the social contract between a taxpayer and the state-why tax should be paid in the first place. This enables taxpayers to connect the payment of tax with expenditure by governments on public goods. Such education is critical and should start early, even in schools, to inculcate a taxpaying culture and share ideals of nationbuilding with taxpayers.

\subsection{Rationale and Benefits of Taxpayer Education and Assistance}

Taxpayer education and assistance provide many benefits to both taxpayers and the TA, as summarized below.

(i) Benefits for taxpayers

- Reduces errors in calculating tax liability

- Reduces compliance costs

- Improves trust in the TA

- Improves business practices when additional accounting/bookkeeping measures are adopted to comply with tax rules

- Enhances nation building and the social contract when citizens are taught the connection between their taxes and public expenditure

(ii) Benefits for the TA

- Promotes voluntary compliance

- Reduces mistakes by taxpayers, which reduces collection costs

- Improves the culture of tax compliance

- Increases tax revenue because the tax base is broadened when compliance is simplified 


\section{Box 10.1 Taxpayer Outreach in Azerbaijan}

Over the past several years, Azerbaijan has been involved in significant reforms of its tax system to make it more efficient and modern, such as the introduction of a "single window" system to register taxpayers; amendments to the tax legislation to modernize administration and to increase the effectiveness of tax controls; raising thresholds for taxation; improvements in the value-added tax (VAT) system; and the launch of the automated tax information system (ATIS). In conjunction with these reforms, Azerbaijan also launched an initiative to improve taxpayer services and outreach. As part of this outreach, in 2005 the government launched The State Program on Improvement of Tax Administration, which, as part of its mandate, operates the "195" call center. The call center allows businesses and individuals to obtain tax information without having to attend the tax offices in person. The call center's services are well utilized; in 2007, responses to a total of 226,845 calls were provided to taxpayers (61,578 live; 165,267 machine-generated). This represented an increase of over 187,091 calls over 2006 . The most popular questions were about tax reports to be submitted to tax authorities (21.2 percent of calls), with income tax (16.5 percent), taxpayer registration (14 percent), VAT (8.7 percent), and withholding taxes (6.5 percent) also the subject of many queries.

The government's outreach program also involved teaching materials at secondary schools in the form of colorfully illustrated children's texts explaining the importance of taxes in building the nation's infrastructure.

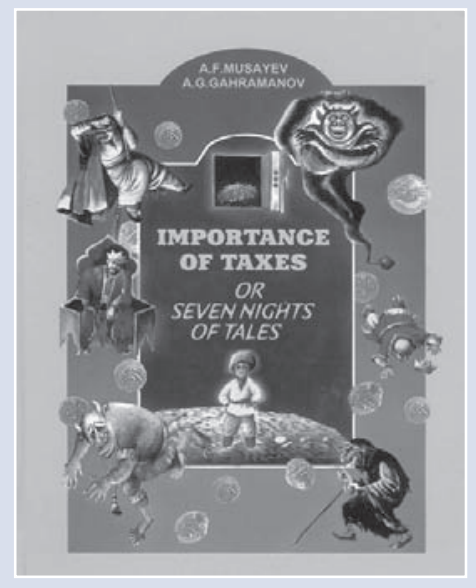

\subsection{Design of a Taxpayer Education and Assistance Strategy}

The traditional role that taxpayer education plays is to help taxpayers comply with basic tax requirements. Taxpayers need to know their obligations under the various tax laws, such as tax rates, availability of tax forms, payment methods, and important due dates. This is usually the responsibility of a specialized department within the TA, located at the headquarters. However, in many countries, taxpayer education and assistance departments either do not exist or are not given the attention they deserve, as they are perceived to play a secondary role in the revenue-collection process.

To encourage voluntary compliance, TAs need to move away from the adversarial role that they have adopted towards taxpayers in the past. The proper stance is for the tax authority to treat the taxpayer as a respected customer; commitment to customer service should therefore be integral.

\subsubsection{Tax Authority Stakeholders}

Table 10.1 sets out some of the key stakeholders and their various roles. 
TABLE 10.1 Tax authority stakeholders

\begin{tabular}{|c|c|}
\hline Stakeholder & Role \\
\hline $\begin{array}{l}\text { - The Ministry of Finance (MoF) } \\
\text { - The President's office/Prime Minister's office } \\
\text { - The legislators/parliamentarians } \\
\text { - Political parties }\end{array}$ & $\begin{array}{l}\text { Promote the message of nation building and } \\
\text { build a tax-paying culture }\end{array}$ \\
\hline - The investment promotion agencies & Assistance for new domestic and foreign investors \\
\hline $\begin{array}{l}\text { - Other ministries } \\
\text { - Local governments }\end{array}$ & $\begin{array}{l}\text { Ensure information on other local taxes and } \\
\text { fees is included in the taxpayer education and } \\
\text { assistance strategy }\end{array}$ \\
\hline $\begin{array}{l}\text { - Central Bank } \\
\text { - Other banks }\end{array}$ & Payment and refund assistance \\
\hline $\begin{array}{l}\text { - Lawyer association (bar) } \\
\text { - Accounting association }\end{array}$ & $\begin{array}{l}\text { Training (and direct assistance to taxpayers) on } \\
\text { interpretation of tax laws, maintaining accounts, } \\
\text { appeals, audits, and taxpayer rights }\end{array}$ \\
\hline - The media & $\begin{array}{l}\text { Deliver the message to the public in an } \\
\text { effective manner }\end{array}$ \\
\hline $\begin{array}{l}\text { - Business associations } \\
\text { - Informal business } \\
\text { - Small business } \\
\text { - Large business } \\
\text { - Exporters } \\
\text { - Importers } \\
\text { - Industry sectors }\end{array}$ & $\begin{array}{l}\text { Assist the TA in designing the taxpayer education } \\
\text { and assistance strategy, and provide ongoing } \\
\text { feedback for improvement }\end{array}$ \\
\hline $\begin{array}{l}\text { - Civil society } \\
\text { - Community leaders/influential persons } \\
\text { and elders }\end{array}$ & $\begin{array}{l}\text { Promote a tax-paying culture and bolster the } \\
\text { message of nation building }\end{array}$ \\
\hline
\end{tabular}

\subsubsection{Target audience}

The tax authority has many avenues available to help disseminate information. However, it should ensure that the type of tax and the level of taxpayer sophistication are considered when selecting a medium for dissemination.

\subsubsection{Cultural context}

Taxpayers have varying backgrounds and different needs. The focus for some taxpayers might be on tax culture, while for others it is more likely the practical aspects of paying taxes. 


\section{BOX 10.2 Examples of Taxpayer Education Channels}

- Help desks

- Radio/TV campaigns

- Print media campaign

- Pamphlets

- Tax bulletins

- Town hall meetings

- Tax clinics
- Media briefings

- Talk shows

- Seminars

- Billboards

- Drama group (Tanzania)

- Secondary schools and college tax educational programs

- Web sites (where sufficient Internet penetration exists)

The TA has to target its message to address the following:

- Cultural sensitivities

- Languages

- Varying levels of local taxation

- Urban and rural taxpayers

- Education levels

- Prevalence of relevant media

- Distance to tax offices

- Familiarity with the concept of taxes.

\subsubsection{The role of the private sector in taxpayer education and assistance}

Private sector businesses could also play a significant role in taxpayer education. They should be involved in helping identify areas where further education is necessary, and helping the tax authority design effective materials. They can be useful in providing feedback during focus groups, surveys, and pilot projects to assess the effectiveness of different education strategies. Private sector businesses can also play a useful role in operating helpdesks answer taxpayer queries and providing the tax authority access to target audiences.

\subsection{Objectives of Taxpayer Education and Assistance}

An effective taxpayer education and assistance program should have several objectives.

- To educate the taxpayers on the laws and how they operate. Tax laws are often complex, and it is therefore a challenge for the tax administration to explain these laws to the taxpayers in simple, easily understood language. Pamphlets 


\section{BOX 10.3 Taxpayer Education Campaigns in Sierra Leone}

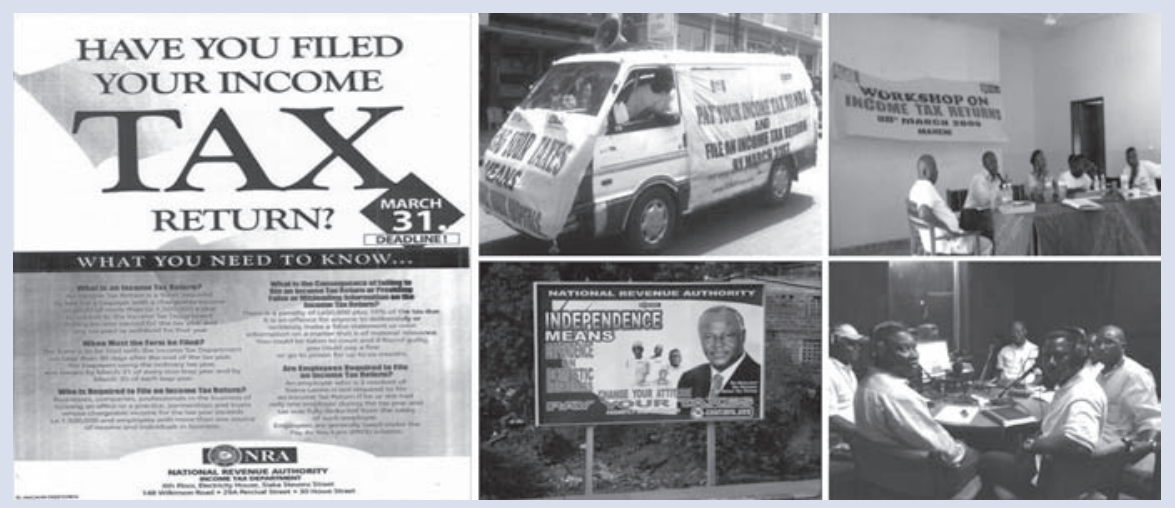

With the assistance of the Investment Climate Advisory of the World Bank Group, the National Revenue Authority (NRA) of Sierra Leone started a major outreach program to the tax administration and taxpayers. This was essential to rebuild the tax system after years of conflict. Central to the program was the overhaul of public affairs and taxpayer education efforts and the creation of a new communication strategy. The NRA used several channels to reach taxpayers, including

- Radio and television discussion programs

- Contracting town criers to disseminate information

- Production and airing of radio and television adverts (jingles)

- Erecting billboards nationwide

- Production of monthly bulletin

- Production of a quarterly newsletter

- Redesigning of the program Web site

- Holding quarterly press conference

- Partnering with radio and nightclub disc jockeys

- Street campaigns

- Partnering with religious leaders.

All these outreach programs are conducted throughout the country. Taxpayers appreciate the fact that they are important part of the tax system and they are playing a role in rebuilding their country.

are the most popular method of communication. However, the audience need not necessarily be those who do not know much about the tax system. Tax professionals such as lawyers and accountants also need to be apprised of the laws; tax bulletins, policy statements, and bylaws can help clarify the law with examples and calculations. Putting such explanations into bylaws has the advantage of giving taxpayers an indication of how the laws will be applied. 


\section{BOX 10.4 Taxpayer Assistance in Canada}

The Canada Revenue Agency (CRA) has made significant strides in providing taxpayers with information to help them better meet their obligations. Some of the taxpayer outreach initiatives launched in the past 15 years are:

- New employer visit program. Department officials are available on request to visit new employers on their own premises.

- Small business information seminars. These seminars provide basic information on selected topics in separate modules for individuals who are thinking about starting a business or who have recently started one.

- Electronic letter creation system (ECLS). In order to prepare consistent and accurate responses to outgoing correspondence, 17,000 standard responses and letters have been developed in both official languages.

- TELEFILE. A free telephone help service is available seven days a week to allow clients to file certain simple tax returns by phone.

- Teaching Taxes Program. Each year, CRA supplies "Teaching Taxes" kits free of charge to teachers and students in high schools and colleges across Canada.

- Tax ombudsman. The taxpayers' ombudsman is an independent and impartial officer who is appointed to look into complaints about the service provided by the CRA. The ombudsman operates at arm's length from the CRA and reports directly to the Minister of National Revenue. The ombudsman's office submits an annual report to the minister that is tabled in parliament, and may issue other reports and/or recommendations concerning any issue within the office's mandate. The ombudsman is the final level of review and complements existing service-related complaint resolution mechanisms internal to the CRA.

- NETFILE. Individual personal income tax returns can be filed via NETFILE, provided they are prepared using approved commercial tax preparation software packages or Web applications.

- Corporation Internet filing. For 2002 and later years, corporations can file their tax returns on the Internet, which results in immediate confirmation, faster processing, and faster refunds.

- Business registrations. Businesses can register for corporate tax, payroll, and customs either in person, by mail, or over the Internet.

- Internet information. All tax forms, publications, and guides are available in both official languages over the Internet.

In addition, in many jurisdictions the rulings on tax appeals and cases are published, and these can provide further guidance on ambiguous provisions in the law.

The government should try to minimize the complexity of tax laws and procedures, particularly as they relate to individuals and small businesses that tend to be less sophisticated and have less access to tax professionals. As well, frequent changes to tax laws should be minimized to cut down the cost of explaining those changes to the taxpayers and to give taxpayers some certainty when structuring their business and personal affairs. 
- To educate taxpayers on how to maintain their books of accounts in the manner required by law. Taxpayers in most cases maintain books of accounts in a manner that is convenient and useful to them. For the purpose of paying taxes however, the TA often expects and assumes that accounts will be maintained in a certain format.

For instance, small businesses often need training in accounting for personal as opposed to business expenses, as they often combine the two. Also, many small businesses do not adopt proper accounting methods for capital expenditures, entertainment costs, depreciation, and bad debts. Tax authorities need to inform taxpayers of the correct format for maintaining such accounts. ${ }^{1}$ The training could be done with the assistance of the accounting community, which should be a natural partner.

- To inform taxpayers about important dates and deadlines. Taxpayers will need to be informed of key dates in the tax compliance process such as: (i) tax return filing dates; (ii) installment due dates; (iii) dates for remitting final taxes; (iv) time to make an appeal; (v) time period for retaining books and records; (vi) time for presuming a tax return is accepted. Taxpayers will need to be informed of the differences in the above deadlines in respect to personal tax, corporate tax, payroll withholdings, sales tax, and any subnational taxes, as well.

- To provide the required information and assist taxpayers in completing their tax returns and other relevant forms in the required format. Under a selfassessment tax system, it is the primary responsibility of the taxpayer to calculate his tax liability. This can be challenging, as income and sales tax laws can be complex for those without a tax or accounting background.

Although a small percentage of taxpayers can employ tax accountants or lawyers to help them with compliance, the TA should provide enough support to allow individuals and businesses to prepare their own forms correctly, particularly since most taxpayers are unable to employ professionals. For this reason, it is imperative that the tax authority establish appropriate means of information dissemination and assistance in compliance. These could include telephone hotlines, helpdesks at tax offices, Internet information, pamphlets, and tax preparation guides.

The proliferation of the Internet has helped many taxpayers to obtain useful information, particularly in developed countries. This is especially notable in

\footnotetext{
1 While accounting training is integral, it should be noted that in many instances, particularly in the case of micro- or subsistence-level businesses, this may not be a realistic or cost-effective endeavor, as the tax revenues at issue may not justify the education and collection efforts required. In those situations, many tax authorities have adopted simplified tax calculations based on turnover and/or other indicators. A full discussion of the considerations of adopting such a system is beyond the scope of this chapter.
} 
countries where taxpayers can e-file their tax returns and obtain information, prepare their return, and submit it all on online. The efficiency is further enhanced where this information directly links to the tax authority's central data records and can be analyzed electronically through the use of specialized software. As developing countries expand their use of the Internet, and as more and more businesses use computers, this option should be explored.

- To provide information on how taxpayers may pay their taxes. Tax authorities need to make payment efficient and should inform taxpayers of the different acceptable methods of payment, such as by mail, in person at various tax offices, at designated banks, or by electronic transfer.

- To provide details on direct support and on how taxpayers may access it. Some taxpayers prefer direct assistance from the tax authorities, particularly where the political history of the country has caused taxpayers to trust only information they get directly from authorities. The TA must always make it possible, through tax assistance centers, for taxpayers to directly approach them with their questions. Such direct assistance could, however, result in complications, because taxpayers often expect to receive assistance with matters that require legal interpretation, and many tax authorities do not want to be liable for providing advice that does not correctly interpret the laws. For this reason, most assistance centers provide only very mechanical advice on filling out tax forms, preparing accounts, methods for making payments, and deadlines.

In the event that a tax authority does decide to provide substantive assistance to taxpayers, it should carefully consider the impact it will have, especially since most small businesses have no resources to hire expert advisers, which means that the tax authority's word on how a particular provision should be interpreted will often be considered the final word on the subject.

- To assist taxpayers in resolving their problems after filing the tax returns or statutory forms. The TA should provide adequate guidance to taxpayers who have made mistakes in the returns and documents they filed and need to amend them. This should include the information that needs to be resubmitted and the deadlines for doing so. However, if the issue arises during the scrutiny of a tax return, the taxpayer might then have to rely on his/her own counsel.

- To provide adequate publicity on administrative and legal remedies available to taxpayers, including in instances of corruption. If the scrutiny of a tax return results in higher tax liability for the taxpayer, it is the duty of the TA to inform the taxpayer of all the legal remedies available to the taxpayer to dispute such a claim. Ideally, the assessment for higher tax should be communicated in writing, along with a written explanation of the deadlines for disputing, how to register a dispute, what information to submit and where to file it. 
- To encourage existing and future taxpayers to participate in the tax system. TAs, particularly in developing countries, often underestimate the importance of their role in nation building and building a culture of compliance. They generally focus on how taxes are collected, rather than on how to promote greater citizen participation in the tax system (how taxes are to be raised, what kinds of taxes would be most effective, what items/persons should be taxed) and the role that taxes play in nation building (what a tax revenue is, and how it should be spent).

The manner in which taxes are spent, however, feeds into tax-compliance behavior. Taxpayer education is a long-term investment and should ideally begin with civics lessons in elementary schools. 


\section{APPENDIX 10A}

\section{Good Practice Examples}

\section{Tax Culture and the Guatemala Tax Authority}

In 2005, the Guatemala Tax Administration (SAT) embarked on a program to reform the taxpayer education provided to its citizens. Initially, the goal of the program was to provide information on procedures and taxpayers' rights and duties. However, when this program was discussed with local authorities and civil society, they came to the conclusion that providing information to the taxpayers on how the tax system worked would not address the fundamental question of why taxpayers should enter the tax system in the first place. Hence, it was necessary to move from a pure revenue focus to address questions on how tax revenues are spent. Subsequently, the SAT undertook a much more comprehensive program to address questions of the "tax culture" in Guatemalan society. Overall, the SAT has three different programs for tax payment facilitation:

- CENSAT Program for taxpayers. Specifically, tax education seminars, new legislation dissemination, workshops, and e-learning for book keepers, taxpayers, customs agents, CPAs, and taxpayers;

- Tax culture. For a broader public; especially for children and young people;

- General social communication campaigns.

Separately, SAT offers taxpayers assistance to help them with tax declarations and payments in person, through e-mail, and over the phone.

The program addressed all aspects of the "tax culture," even making it a part of the syllabus in elementary schools. The program worked with the Ministry of Education (MoE), and with accounting and other professionals to make taxpayer educationespecially the role of taxes in nation building - a part of their elementary education. A television series was produced specifically aimed at children. Musicals and audiovisual exhibitions were organized to spread the message. Special efforts were made to address the special requirements of the indigenous Mayan population. 
This program demonstrated the need for the TA to work with other ministries such as the MoF and MoE and with local government and civil society to design and roll out a taxpayer education program.

\section{Sierra Leone: Popularizing a New Tax through Songs}

\section{BOX 10A.1 GST-A Hit on the Music Scene}

An unlikely song about tax is set to become a hit on the Sierra Leone music scene.

As part of the Crown Agents' program to support the modernization of the National Revenue Authority (NRA), the song has been commissioned by the organization to promote the advantages of Sierra Leone's goods and services tax (GST), which is due to replace seven existing taxes in the country later this year.

It has been written and recorded by one of Sierra Leone's top bands-the internationallyfamous Jungle Leaders-and was released free of charge to radio stations, nightclubs, disc jockeys, and discotheques. The song is one of the innovative ways being used to reach a wide section of the population to explain the advantages and benefits GST will bring. The band incorporated slogans into the lyrics resulting from brainstorming sessions held during training workshops with staff members.

The Jungle Leaders-Alfred Mansaray (aka Funky Fred), Handel Metzger (aka Del), and singer Sahr Josiah (aka Sly Dee) - have performed in the United States and Europe as well as all parts of Sierra Leone. They describe their music as 'reggae with a Sierra Leone dimension.' "This was a very unusual challenge. At the same time we were very proud to create this music and be part of a project that will help Sierra Leone. We have had the opportunity to travel to other parts of the world and have seen how taxes build countries. I believe that GST will be good for Sierra Leone and help it to develop," says Alfred Mansaray.

On behalf of the NRA, Alfred Akibo Betts says: "We are absolutely delighted with the GST song. Not only does it promote the value of GST but it is a brilliant tune that will make everyone want to dance. We hope that people will be singing along all over Sierra Leone and remember the tax-friendly catch phrases in the song."

In addition to the GST song, the NRA is undertaking a wide-ranging taxpayer education program in preparation for the introduction of GST. It has commissioned Michael Charlie Hinga, one of Sierra Leone's best-known radio jingle writers, to come up with a series of GST jingles that will be produced in five local languages, as well as English. These will be played on radio over

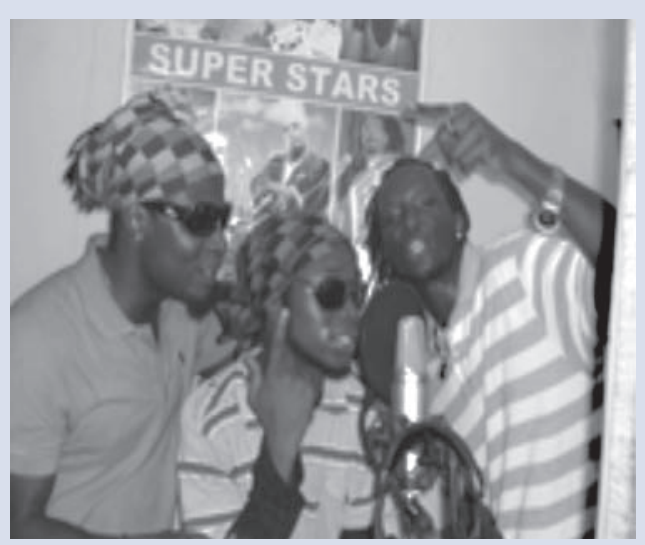
the coming weeks to explain in everyday terms how GST will operate and how it will benefit all Sierra Leoneans.

A Taxpayer Services Unit has been established at the NRA offices in Freetown, where taxpayers can seek personal advice on any aspect of their tax affairs. A series of public information leaflets about GST is also being produced and the NRA's Web site (www.nra.gov.sl) is being updated to enable these publications and copies of the GST law and GST regulations to be downloaded.

Source: Crown Agents website. 


\section{Further Guidance}

- Communication Strategy for Tax in Yemen and Sierra Leone 2008. CIC, The World Bank Group.
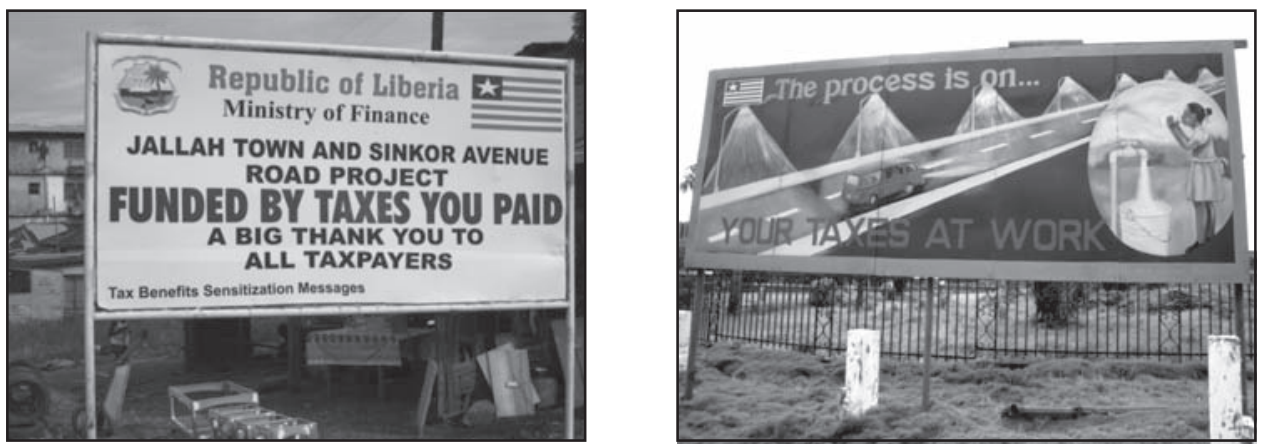

Improving taxpayer morale in Liberia through billboards 



\section{References}

Acuna, Ramirez, and Luis Fernando. 1992. "Privatization of Tax Administration." In Richard M. Bird and Milka Casangera de Jantscher, eds., Improving Tax Administration in Developing Countries. Washington, DC: International Monetary Fund.

Adams, Charles. 1993. For Good and Evil. The Impact of Taxes on the Course of Civilisation. London: Madison Books, p. 21.

Alesina, Alberto, and Geroge-Marios Angeletos. 2003. "Fairness and Redistribution: US versus Europe.” Research Working Paper No. 1983, Harvard Institute.

Alesina, Alberto, and Danni Rodrik. 1991. "Distributive Politics and Economic Growth.” NBER Paper 3668.

Alm, James, and Sally Wallace. 2006. "Can Developing Countries Impose a Personal Income Tax?” In James Alm, Jorge Martinez, and Mark Rider, eds., The Challenges of Tax Reform in the Global Economy. Berlin: Springer-Verlag.

Alm, James, I. Sanchez, and A. De Juan. 1995. "Economic and Non-Economic Factors in Tax Compliance." KYKLOS 48: 3-18.

Andreoni, James, Brian Erard, and Jonathan Feinstein. 1998. "Tax Compliance." Journal of Economic Literature 36: 818-60.

Apte, Pradeep, and Arindam Das-Gupta. 2002. "Improving Maharashtra's Own Revenue Performance." Background Paper for World Bank, 2003, in Maharashtra: Reorienting Government to Facilitate Growth and Reduce Poverty. Washington, DC: World Bank.

Aterido, Reys, Mary Hallward-Driemeier, and Carmen Pagés. 2007. "Investment Climate and Employment Growth: The Impact of Access to Finance, Corruption and Regulation Across Firms." Inter-American Development Bank (IADB) Working Paper 626. http://idbdocs.iadb.org/wsdocs/getdocument.aspx?docnum=1185412.

Auditor General of Canada. 2007. "2007 Status Report of the Auditor General of Canada," Chapter 7 (International Taxation-Canada Revenue Agency). http:// www.oag-bvg.gc.ca/domino/reports.nsf/html/20070207ce.html/\$file/20070207ce. pdf [accessed January 12, 2007]. 
Baer, Katharine, Olivier P. Benon, and Juan Rivera Toro. 2002. "Improving Large Taxpayers' Compliance: A Review of Country Experience.” Occasional Paper 215, Washington, DC: International Monetary Fund.

International Monetary Fund, Bagchi, Amaresh, Richard M. Bird, and Arindam DasGupta. 1995. "An Economic Approach to Tax Administration Reform.” Discussion Paper No. 3, International Centre for Tax Studies, Faculty of Management, University of Toronto.

Bahl, Roy, and Jorge Martinez-Vazquez. 2006. "The Property Tax in Developing Countries: Current Practices and Prospects." Lincoln Institute of Land Policy Working Paper. http://www.lincolninst.edu/pubs/PubDetail.aspx?pubid=1256.

Bates, Robert. 1996. "Institutions as Investments." African Economic Research Consortium, Nairobi. p. 17.

Batra, Geeta, Daniel Kaufmann, and Andrew H. W. Stone. 2003. "Investment Climate Around the World: Voices of the Firms from the World Business Environment Survey." Washington, DC: World Bank Group. http://www.worldbank.org/wbi/ governance/pdf/firmsspeak.pdf.

Baldry, Jonathan C. 1993. "Collusive Income Tax Evasion in Small Business: A Theoretical Analysis." Paper presented at the 49th Congress of the International Institute of Public Finance, Berlin.

BBC (British Broadcasting Corporation). 2007. "Data Lost by Revenue and Customs." November 21. http://news.bbc.co.uk/2/hi/uk_news/7103911.stm.

Beales, R. 2007. "Survey Shows Few Checks for Bribery." Financial Times, Asia print edition, April 13, p. 18.

Bergman, Marcelo. 2003. "Tax Reforms and Tax Compliance: The Divergent Paths of Chile and Argentina." Journal of Latin American Studies 35: 593-624.

Bernstein, Thomas, and Xiaobo Lu. 2008. "Taxation and Coercion in Rural China." In Deborah Brautigam and others, eds., Taxation and State Building in Developing Countries. Cambridge, UK: Cambridge University Press.

Bird, Richard. 1992. "Tax Reform in Latin America: A Review of Some Recent Experiences.” Latin American Research Review 27 (1): 7-36.

Bird, Richard. 1999 "Rethinking Subnational Taxes: A New Look at Tax Assignment." IMF WP/99/165. http://www.imf.org/external/pubs/ft/wp/1999/wp99165.pdf.

Bird, Richard. 2000. "Subnational VATs: Experience and Prospects." Washington, DC: World Bank Group. http://www1.worldbank.org/wbiep/decentralization/ Module7/Subnational\%20VATs.pdf. 
Bird, Richard. 2007. "Tax Challenges Facing Developing Countries: A Perspective from Outside the Policy Arena." Draft Paper, International Tax Program, Joseph L. Rotman School of Management, University of Toronto.

Bird, Richard, and Eric Zolt. 2003. "Introduction to Tax Policy Design and Development." Washington, DC: World Bank.

Bird, Richard. 2008. "Technology and Taxation in Developing Countries: From Hand to Mouse.” http://papers.ssrn.com/sol3/papers.cfm?abstract_id=1086853.

Bird, Richard M., and Sally Wallace. 2003. "Is It Really So Hard to Tax the Hard-toTax? The Context and Role of Presumptive Taxes." International Tax Program, Toronto.

Bird, Richard M., and Sally Wallace. 2004. "Is It Really So Hard to Tax the Hard-toTax? The Context and Role of Presumptive Taxes." In J. Alm, J. Martinez-Vazquez, and S. Wallace, eds., Taxing the Hard-To-Tax: Lessons from Theory and Practice. Amsterdam: North-Holland.

Bird, Richard M., J. Martinez-Vazquez, and B. Torgler. 2006. "Societal Institutions and Tax Effort in Developing Countries." In J. Alm, J. Martinez-Vazquez, and M. Rider, eds., The Challenges of Tax Reform in the Global Economy, 283-338. New York: Springer.

Biz/Ed website. 2008. "A Framework for Designing Projects for Monitoring and Evaluation Activity." Institute of Fiscal Studies. http://www.bized.co.uk/virtual/ economy/policy/tools/income/inctaxth1.htm [accessed May 14, 2008].

Boadway, Robin, Sandra Roberts, and Anwar Shah. 1994. "Fiscal Federalism Dimension of Tax Reform in Developing Countries." Policy Research Working Paper 1385, World Bank, Washington, D.C. http://ideas.repec.org/p/wbk/wbrwps/1385.html.

Bolnick, Bruce. 2004. "Effectiveness and Economic Impact of Tax Incentives in the Southern African Development Community (SADC) countries." Technical report submitted by Nathan-MSI Group to USAID/RCSA SADC Tax Subcommittee, SADC Trade, Industry, Finance and Investment Directorate.

Bora, Bijit. 2002. "Foreign Direct Investment - research issues". Routledge studies in International Business and the World Economy.

Borck, Rainald. 2004. "Stricter Enforcement May Increase Tax Evasion." European Journal of Political Economy 20 (3) (September): 725-37.

Bowles, R. 1998. "Minimizing Corruption in Tax Affairs." In Cedric Sanford, ed., Further Issues in Tax Reform, 65-86, 82. Bath: Fiscal Publications.

Brautigam, Deborah, and others, eds. 2008. Taxation and State Building in Developing Countries. Cambridge, UK: Cambridge University Press. 
Brett and Keen. 2000. "Political Uncertainty and Earmarking of Environmental Taxes," Journal of Public Economics, 75, 315-40.

Brown, J., and François Vaillancourt. 1986. "The Administrative and Compliance Costs of the Federal Sales Tax System." A study prepared for the Department of Finance, Government of Canada.

Bryne, Peter D. 1998. "Privatization in the Area of Tax Administration: An Overview." Harvard Institute of International Development. http:/www.cid.harvard.edu/ hiid/508.pdf.

Buchanan, James M. 1963. "The Economics of Earmarked Taxes," Journal of Political Economy, 71, 457-69.

Buchanan, James M. 1999. "Public Finance in Democratic Process: Fiscal Institutions and Individual Choice.” Indianapolis: Liberty Fund Inc., US.

Burke, Edmund (quoted in P. O'Brien). 2001. "Fiscal Exceptionalism: Great Britain and its European Rivals." LSE Paper 65/01, p. 21.

Butler, A., A. Adonis, and T. Travers. 1994. "Failure in British Government: The Politics of the Poll Tax." Oxford, p. 303.

Caseley, Jonathan. 2004. "Public Sector Reform and Corruption: CARD Façade in Andhra Pradesh." Economic and Political Weekly 39 (March 13): 1151-56.

CFIB (Canadian Federation of Independent Business). 2005a. "Canada's Revenue Agency Five Years After.” http://www.cfib.ca/research/reports/crareport.pdf.

Chattopadhyay, Saumen, and Arindam Das-Gupta. 2002. "The Income Tax Compliance Cost of Indian Corporations." Report of a Study for the Planning Commission, National Institute of Public Finance and Policy (NIPFP), New Delhi. http:// www.planingcommission.nic.in/reports.

Chattopadhyay, Saumen, and Arindam Das-Gupta. 2002a. "The Compliance Cost of the Personal Income Tax and Its Determinants." Report of a study for the Planning Commission, New Delhi: NIPFP. http://www.planningcommission.nic.in/ reports.

Chattopadhyay, Saumen, and Arindam Das-Gupta. 2007. "Implementing Computerisation and Information Technology for Tax Administration." London: Commonwealth Secretariat.

Chen, Duanjie. 2000. "The Marginal Effective Tax Rate: The Only Tax Rate That Matters in Capital Allocation.” Backgrounder (occasional paper), Toronto: C.D. Howe Institute. 
Chen, Duanjie, and J. M. Mintz. 1993. "Taxation of Capital in Ontario and Canada." In A.M. Maslove, ed., Business Taxation in Ontario. Toronto: University of Toronto Press.

Chipeta, C. 2002. "The Second Economy and Tax yield in Malawi." Africa Economic Research Consortium, Nairobi.

Chirinko, Robert S., and Huntley Schaller. 2008. "The Irreversibility Premium.” CESIfo Working Paper 2265. http://www.CESifo-group.org/wp.

CMI (Christian Michelsen Institute). 2005. "Revenue Administration and Corruption: What Works?” CMI Brief 4 (2) (November), Christian Michelsen Institute (CMI), Bergen, Norway. http://www.cmi.no.

Cummings, R. G., J. Martinez-Vazquez, M. McKee, and B. Torgler. 2006. "Effects of Tax Morale on Tax Compliance: Experimental and Survey Evidence." Berkeley.

Das-Gupta, Arindam. 1994. "A Theory of Hard to Tax Groups." Public Finance 49 (Supplement): 28-39. Proceedings of the 49th Congress of the International Institute of Public Finance, Berlin, 1993.

Das-Gupta, Arindam. 2006c. "The Income Tax Compliance Cost of Corporations in India, 2000-01." Vikalpa (Journal of the Indian Institute of Management, Ahmedabad) 31(4): 9-30.

Das-Gupta, Arindam. 2007. "Corruption." In Kaushik Basu, ed., The Oxford Companion to Economics in India, 76-79. New Delhi: Oxford University Press.

Das-Gupta, Arindam. 2008. "A Scorecard to Assess Readiness for Globalization of Developing Country Tax Administrations." Presentation notes for the conference on Tax Reform in Globalization Era, February 21-24, Tokyo.

Das-Gupta, Arindam, and Dilip Mookherjee. 1998. Incentives and Institutional Reform in Tax Enforcement. New Delhi: Oxford University Press.

Das-Gupta, Arindam, and Xun Wu. 2008. "Corporate Ownership and Bribery." Manuscript, Lee Kuna Yew School of Public Policy, National University of Singapore.

Das-Gupta, Arindam, Michael Engelschalk, and William Mayville. 1999. "An Anticorruption Strategy for Revenue Administration.” PREM Note 33, Washington, D.C.: World Bank. Das-Gupta, Arindam, R. Lahiri, and D. Mookherjee. 1995. "Income tax compliance in India: An empirical analysis." World Development 23: 2051-68.

Das-Gupta, Arindam, Shanto Ghosh, and Dilip Mookherjee. 2004. "Tax Administration Reform and Taxpayer Compliance in India." International Tax and Public Finance 11 (forthcoming). 
de Mendoça, Gonçalves, and Marcelo Amaral. 2004. "Subnational Value Added Tax in a Federation-An Analysis of the Brazilian Case." George Washington University Institute of Brazilian Studies. http://www.gwu.edu/ ibi/minerva/Fall\%202004/ subnational\%20value\%20added\%20tax.pdf.

De Mooij, Ruud S., and Sjef Ederveen. 2003. "Taxation and Foreign Direct Investment: A synthesis of empirical research." International Tax and Public Finance Vol. 10(6), pp. 673-93.

Desai, Mihir, F. Foley, and J. R. Hines Jr. "Taxation and Multinational Activity: New Evidence, New Interpretations," Survey of Current Business 86, no. 2 (February 2006), 16-22.

Devas, Nick, Simon Delay, and Michael Hubbard. 2001."Revenue Authorities: Are They the Right Vehicle for Improved Tax Administration?" Public Administration and Development 21: 211-22.

Devereux, Michael P., and Rachel Griffith. 2003. "Evaluating Tax Policy for Location Decisions." International Tax and Public Finance 10: 107-26.

Dewid, A., and S. Steinmo. 2002. "The Political Economy of Taxes and Redistribution in Japan." Social Science Japan Journal 5 (2): 159-78.

Easter, Gerald. 2008. "Capacity, Consent, and Tax Collection in Post-Communist States." In Deborah Brautigam and others (2008), 74-79.

Ebrill, Liam, Michael Keen, Jean-Paul Bodin, and Victoria Summers. 2001. "The Modern VAT." Washington, DC: International Monetary Fund.

Edwards, Chris. 2004. "State Corporate Income Taxes Should Be Repealed." Cato Institute Tax and Budget Bulletin, April 19.

Engelschalk, Michael. 2000. "Computerizing Tax and Customs Administration." PREM Note 44, Washington, DC: World Bank, http:/www1.worldbank.org/prem/ PREMNotes/premnote44.pdf.

Engelschalk, Michael. 2005. "Small Business Taxation in Transition Countries." http:// www.businessenvironment.org/dyn/be/docs/78/Session3.2EngelshalkDoc.pdf.

Erard, Brian. 1997. "The Income Tax Compliance Burden on Canadian Big Business." Working Paper 97-2, Technical Committee on Business Taxation (April).

Estela, Manuel. 2001. "Strengthening Peru's Tax Agency." PREM Note 60, Washington, DC: World Bank, http://www1.worldbank.org/prem/PREMNotes/premnote60.pdf.

Evans, Chris. 2003. "Studying the Studies: An Overview of Recent Research into Taxation Operating Costs." eJournal of Tax Research 1(1): 64-92. http://www.atax .unsw.edu.au/ejtr/content/previous_issues.htm. 
Everest-Phillips, Max (ed). 2008a. Political Economy of Taxation in Developing Countries: Challenges to Practitioners. World Bank Group Department for International Development (WBG-DFID).

Everest-Phillips, Max. 2008b. "Tax Simplification Source Book.” DFID.

Fargher, Lane, and others. 2007. "Revenue, Voice, and Public Goods in Three PreModern States." Comparative Studies in Society and History 49 (4): 848-82.

Feld, Lars, and Bruno Frey. 2007. "Tax Compliance as the Result of a Psychological Tax Contract: The Role of Incentives and Responsive Regulation.” Law E Policy 29 (1): 102-20.

FIAS (Foreign Investment Advisory Service). 2006. "Sierra Leone: Tax and the Investment Climate." International Finance Corporation (IFC).

FIAS (Foreign Investment Advisory Service). 2008. "Designing a Tax System for Micro and Small Businesses: Guide for Practitioners." International Finance Corporation (IFC).

Fisman, Raymond, and Shang-Jin Wei. 2004. "Tax Rates and Tax Evasion: Evidence from 'Missing Imports' in China." Journal of Political Economy 112(2): 471-96.

Fjeldstad, Odd-Helge. 2002. "Fighting Fiscal Corruption: The Case of the Tanzania Revenue Authority." CMI Working Paper No. 3, Bergen. http://www.cmi.no/ publications.

Fjeldstad, Odd-Helge. 2005. "Corruption in Tax Administration: Lessons from Institutional Reforms in Uganda." CMI Working Paper 10. http://www.cmi.no/ publications.

Fjeldstad, Odd-Helge, Ivar Kolstad, and Siri Lange. 2003. "Autonomy, Incentives and Patronage: A Study on Corruption in the Tanzania and Uganda Revenue Authorities." Bergen: Chr. Michelsen Institute.

Fortin, Bernard, and Guy Lacroix. 1994. "Labour Supply, Tax Evasion and the Marginal Cost of Public Funds: An Empirical Investigation." Journal of Public Economics 55: 407-31.

Fox, William F., and John A. Swain. 2007. "The Federal Role in State Taxation: A Normative Approach.” National Tax Journal LX 3: 611-30.

Gauthier, Bernard, and Ritva Reinnika. 2006. "Shifting Tax Burdens Through Exemptions and Evasion: An Empirical Investigation of Uganda." Journal of African Economies 15: 373-98.

Gill, Jit B. S. 2000. "A Diagnostic Framework for Revenue Administration.” Technical Paper 472, Washington, DC: World Bank. 
Gordon, Richard K. 1996. "Law of Tax Administration and Procedure." In Victor Thuronyi, ed., Tax Law and Drafting, Vol. 1, 95-134. Washington, DC: International Monetary Fund.

Government of New Zealand. 2007. "Reducing Tax Compliance Costs For Small And Medium-Sized Enterprises.” http://www.taxpolicy.ird.govt.nz/publications/index .php?catid=2.

Government of India, Ministry of Finance. 2006. "Annual Report, 2005-6." New Delhi. http://finmin.nic.in/downloads/reports/AR_ENGLISH.pdf. http://www.incometax india.gov.in/archive/TheIncomeTaxOmbudsmanGuidelines2006_08122006.pdf [accessed May 3, 2008].

Government of Sri Lanka, Ministry of Finance and Planning. 2008. "Announcement of the Establishment of the Office of the Tax Ombudsmen." http://www.treasury .gov.lk/keytopic/taxombudsman.htm [accessed May 7, 2008].

Greenberg, J. 1984. "Avoiding Tax Avoidance: A (Repeated) Game-Theoretic Approach," Journal of Economic Theory, 32, 1-13.

Grout, Paul A., and Margaret Stevens. 2003. "The assessment: Financing and managing public services." Oxford Review of Economic Policy, 19(2), 215-34.

Guyer, Jane I. 1992. "Representation without Taxation: An Essay on Democracy in Rural Nigeria, 1952-1990." African Studies Review 35(1): 41-79.

H. M. Government (United Kingdom). 1983. Committee on the Enforcement Powers of the Revenue Departments, Cmnd. 8822, (Keith Committee). London: Parliament of the United Kingdom.

H. M. Revenue and Customs. 2007. HMRC Compliance Cost Reviews (CCRs). http:// www.hmrc.gov.uk/ccr/index.htm

H. M. Revenue and Customs. 2007a. "Lessons on Improving Impact Assessments." http://www.hmrc.gov.uk/ccr/checklist.pdf.

Hallward-Driemeier, Mary, Scott Wallsten, and Lixin Collin Xu. 2003. "The Investment Climate and the Firm; Firm-Level Evidence from China." Policy Research Working paper 3003, Washington, DC: World Bank, http://ideas.repec.org/p/ wbk/wbrwps/3003.html.

Harriss, G., and L. King. 1975. "Parliament and Public Finance in Medieval England to 1369." Oxford, 343.

Hettich, W., and S. Winer. 1988. "Economic and Political Foundations of Tax Structure." American Economic Review 78: 705.

Hettich, Walter, and Stanley Winer. 1999. "Democratic Choice and Taxation: A Theoretical and Empirical Analysis." Cambridge. 
Hettich, Walter, and Stanley Winer. 2000. "Democratic Choice and Taxation: A Theoretical and Empirical Analysis.” Public Choice 103: 44-73.

Hettich, Walter, and Stanley Winer. 2002. "The Political Economy of Taxation: Positive and Normative Analysis When Collective Choice Matters.” p. 11.

Hettich, Walter, and Stanley Winer. 2006. "Analyzing the Interdependence of Regulation and Taxation." Public Finance Review 34 (4): 355-80.

Hindriks, Jean, Michael Keen, and Abhinay Muthoo. 1999. "Corruption, Extortion and Evasion." Journal of Public Economics 74: 395-430.

Hughes, Siobhan, and Tom Wright. 2007. Monsanto Ex-Official Settles Bribe Charges.” Wall Street Journal Asia (March 9): 4.

IMF (International Monetary Fund). 2001. "The Modern VAT.” Washington, DC: IMF.

INTOSAI (International Organisation of Supreme Audit Institutions). 1977. "Lima Declaration, IXth INTOSAI Congress.” http://www.intosai.org/Level2/2_LIMADe.html.

Ivanova, Anna, Michael Keen, and Alexander Klemm. 2005. "The Russian "Flat Tax" Reform." Economic Policy 20: 397-444.

James, Sebastian. 2007. "The Effect of Tax Rates on Declared Income: An Analysis of Indian Taxpayer Response to Changes in Income Tax Rates." Mimeo, Ph.D. Dissertation, Harvard University.

James, Sebastian, Paul Barbour, and Richard Stern. 2007. "Tax and Investment; Through the Growth Lens." Presentation at FIAS conference http://www.oecd .org/dataoecd/13/47/38880972.pdf.

James, Sebastian, and Van Parys. 2009. "Effectiveness of Incentives in Promoting Investment in CEMAC-UMEOA." Mimeo. Washington, DC: World Bank.

Jenkins, Glen. 1994. "Modernizing of Tax Administration: Revenue Boards as an Instrument for Change." Bulletin for international fiscal documentation 48 (2).

Johnson, Noel. 2001. "Committing to Civil Service Reform: The Performance of Preshipment Inspection under Different Institutional Regimes." Working Paper 2594, Washington, D.C.: World Bank, Johnson, Simon and others. 1998. "Regulatory Discretion and the Unofficial Economy." American Economic Review 88 (2): 387-432.

Johnston, David Cay. 1998. "3 Businessmen Testify of Armed Raids by I.R.S." The New York Times, Late Edition, Section A, Page 28, Column 1, April 30. http://www nytimes.com.

Johnson, Sir Alexander. 1965. "The Inland Revenue." Allen \& Unwin, London. 
Joulfaian, David. 1993. "Corporate Income Tax Evasion.” Paper presented at the 49th Congress of the International Institute of Public Finance, Berlin.

Joulfaian, David, and Mark Rider. 1998. "Differential Taxation and Tax Evasion by Small Business." National Tax Journal 51: 675-87.

Kahn, Charles, Emilson C. D'Silva, and James Ziliak. 2001. "Performance-Based Wages in Tax Collection: The Brazilian Tax Collection Reform and Its Effects." Economic Journal 111: 118-205.

Kangave, Jalia. 2005. "Improving Tax Administration: A Case Study of the Uganda Revenue Authority." Journal of African Law 49 (2): 145-76.

Kato, Junko. 2003. "Regressive Taxation and the Welfare State: Path Dependence and Policy Diffusion.” Cambridge.

Klemm, Alexander. 2008. "Effective Average Tax Rates for Permanent Investment." IMF Working paper WP/08/56, Washington, DC: International Monetary Fund.

Klemm, Alexander. 2009. "Causes, Benefits, and Risks of Business Tax Incentives." IMF Working Paper. Washington, DC: International Monetary Fund.

Lieberman, Evan. 2002. "Taxation Data as Indicators of State-Society Relations: Possibilities and Pitfalls in Cross-National Research." Studies in Comparative International Development 36 (Winter) (4): 89-115, 94.

Lieberman, Evan. 2005. "Race and Regionalism in the Politics of Taxation in Brazil and South Africa." Cambridge.

Li, Quan. "Democracy, Autocracy, and Tax Incentives to Foreign Direct Investors: A Cross-National Analysis.” The Journal of Politics 68 (1): 62-74.

Li, Xin. 2007. "Three Essays on Tax Compliance, Social Identities, and Fiscal Policy." The Humanities and Social Sciences 67 (07): 2675.

Low, Patrick. 1995. "Preshipment Inspection Services." Discussion Paper 278, Washington, DC: World Bank.

Lund, Francie, and Caroline Skinner. 2005. "Creating a Positive Business Environment for the Informal Economy: Reflections from South Africa." http://www.business environment.org/dyn/be/docs/79/Session3.3Lund-Skinner2Doc.pdf.

Mahon, James. 2004a. "Causes of Tax Reform in Latin America, 1977-95." Latin American Research Review 39 (1): 3-30.

Mahon, James. 2004b. "Tax Reform and its Determinants in Latin America 1977-94." Implications for Theories of State Development.

Marjit, S., V. Mukherjee, and A. Mukherjee. 2000. "Harassment, Corruption and Tax Policy." European Journal of Political Economy 16: 75-94. 
Martinez-Vazquez, Jorge, and Andrey Timofeev. 2005. "Choosing between Centralized and Decentralized Models of Tax Administration." Working Paper 05-02, International Studies Program, Andrew Young School of Policy Studies, Georgia State University, Atlanta.

Martinez-Vazquez, Jorge, Charles McLure, and François Vaillancourt. 2006. "Revenues and Expenditures in an Intergovernemental Framework" In Richard Bird and François Vaillancourt, ed., Perspectives on Fiscal Federalism, 15-34. Washington, DC: World Bank Institute.

McCarten, William. 2004. "Large Taxpayer Units and the VAT." In James Alm, Jorge Martinez, and Mark Rider, eds., The Challenges of Tax Reform in the Global Economy. Berlin: Springer-Verlag.

McDonald, John, and G. Snooks. 1986. "Domesday Economy.” London: Oxford University Press.

McKenzie, K. J., M. Mansour, and A. Brûlé. 1998. "The Calculation of Marginal Effective Tax Rates.” Working Paper 97-15, Technical Committee on Business Taxation, Ottawa.

McLane, John R. 1977. "Revenue Farming and the Bengal Zamindari System." In Robert E. Frykenberg, ed., Land Tenure and Peasant in South Asia. New Delhi: Orient Longman.

McLure, Charles E. 2001. "The Tax Assignment Problem: Ruminations on How Theory and Practice Depend on History." NTJ 54 (2): 339-61(9).

McLure, Charles E. 2006. "Transfer Pricing and Tax Havens: Mending the LDC Revenue Net." In James Alm, Jorge Martinez, and Mark Rider, eds., The Challenges of Tax Reform in the Global Economy. Berlin: Springer-Verlag.

McMillan, Margaret, and William Masters. 2000. "Africa's Growth Trap: A PoliticalEconomy Model of Taxation, R\&D and Investment." Paper 124, Oxford Centre for the Study of African Economies.

Merrifield, John. 1991. The Institutional And Political Factors Which Influence Taxation. Public Choice: 295-311.

Mikesell, John. 2007. "Developing Options for the Administration of Local Taxes: An International Review." Public Budgeting and Finance 27(1): 41-68.

Ministry of Finance, the Netherlands. 2005. "International Comparison of Measurements of Administrative Burdens Related to VAT in the Netherlands, Denmark, Norway, and Sweden. http://www.administrative-burdens.com/default.asp?page=142.

Mintz, Jack M. 2001. "A Eulogy for the Use of Average Tax Rates in Investment Equations." In J. Hines, ed., Studies in International Taxation. Chicago: University of Chicago Press. 
Mintz, Jack M. 2007. The 2005 Tax Competitiveness Report: A Call for Comprehensive Tax Reform. C. D. Howe Institute Commentary, No 254, Toronto: C.D. Howe Institute.

Mintz, Jack M., and Duanjie Chen. 2008. "Taxing Business Investments: A New Ranking of Effective Tax Rates on Capital.” Washington DC: World Bank, July 2008.

Mo, Phyllis Lai Lan. 2003. "Tax Avoidance and Anti-Avoidance Measures in Major Developing Economies." Westport, Conn. Praeger.

Mookherjee, Dilip. 1998. "Incentive Reforms in Developing Country Bureaucracies: Lessons from Tax Administration." In B. Pleskovic and J. E. Stiglitz, eds., Proceedings of the Annual World Bank Conference on Development Economics, 103-125. Washington, D.C.: World Bank.

Mookherjee, Dilip, and Ivan P. L. Png. 1994. "Marginal Deterrence in Enforcement of Law." Journal of Political Economy 102: 1039-66.

Mookherjee, Dilip, and Ivan P. L. Png. 1995. "Corruptible Law Enforcers: How Should They Be Compensated?" Economic Journal 105: 145-59.

Mookherjee, Dilip, and Ivan P. L. Png. 2007. "How Does Taxation Affect the Quality of Governance?" IDS Working Paper 280.

Mookherjee, Dilip, and Ivan P. L. Png. 2008. "Between Coercion and Contract." In Deborah Brautigam and others (2008), 55.

Nehring, Holger, and Florian Schui. 2008. "Global Debates about Taxation.” London: Palgrave Macmillan, p. 206.

New York Times, The. 1998. "I.R.S. Hearings Resume." The New York Times, April 29, Late Edition, Section A, Column 5, Page 1. http://www.nytimes.com.

North, Douglass. 1981. "Structure and Change in Economic History." New York: W.W. Norton.

North, Douglass, and others. 2007. "Limited Access Orders in the Third World: A New Approach to the Problems of Development." NBER.

OECD. 2000. "Improving Access to Bank Information for Tax Purposes."

OECD. 2003. "Improving Access to Bank Information for Tax Purposes: The 2003 Progress Report." http://WWW.OECD.ORG/dataoecd/5/0/14943184.pdf?channelId=33 767\&homeChannelId=34897\&fileTitle=Improving+Access+to+Bank+Information +for+Tax+Purposes+-+The+2003+Progress+Report.

OECD. 2005. "Articles of the Model Convention with Respect to Taxes on Income and on Capital, as They Read on July 15, 2005." http://www.oecd.org/dataoecd/ 50/49/35363840.pdf. 
OECD. 2006a. "Tax Administration in OECD and Selected Non-OECD Countries." Comparative Information Series.

OECD. 2006c. "Policy Framework for Investment." http://www.oecd.org/dataoecd/ 22/8/35815912.pdf.

OECD. 2006d. "OECD Bribery Awareness Handbook for Tax Examiners." http://www .oecd.org/document/39/0,3343,en_2649_37447_37111335_1_1_1_37447,00.html.

OECD. 2007a. "Implication of Tax Policy for SME Growth and Tax Compliance." Issues Paper, Working Group 3. http://www.oecd.org/dataoecd/51/12/38758522.pdf.

OECD. 2007b. "Fiscal Policy and Legitimacy in Latin America": p. 3.

Oldman, Oliver. 1965. "Controlling Income Tax Evasion," In Joint Tax Program, Problems of Tax Administration in Latin America. Baltimore: Johns Hopkins University Press.

Pandey, Arvind. 2002. "E-Governance Totters in Gujarat." The Times of India, July 22.

Parker, David. 1990. "Tackling Tax Evasion in the U.K." Working Paper, Cranfield School of Management, Cranfield, United Kingdom.

Poapongsakorn, Nipon, Kovit Charnvitayapong, Duangmanlee Laovakul, and Bev Dahlby. 2000. "A Cost Benefit Analysis of the Thailand Taxpayer Survey." International Tax and Public Finance 7: 63-82.

Polackova Brixi, Hana, Christian M. A. Valenduc, and Zicheng Li Swift. "Tax Expenditures: Shedding Light on Government Spending through the Tax System.” Washington, DC: World Bank.

Prasad, Monica. 2005. "Why Is France so French? Culture, Institutions, and Neoliberalism, 1974-81.” American Journal of Sociology 111: 357-407, 362.

Public Broadcasting Service (U.S.A.). 1999. Transcript of the TV Show "Washington Week in Review." April 16, http://www.pbs.org/weta/washingtonweek/transcripts/ transcript990416.html.

Putnam, Bertha Haven. 1908. "The Enforcement of the Statute of Labourers." New York: Columbia University, 98-149.

Rajaraman, Indira. 1995. "Presumptive Direct Taxation: Lessons From Experience In Developing Countries." Economic and Political Weekly 30 (May): 1103-24.

Ramalho, Rita. 2007. "Adding a Million Taxpayers." Celebrating Reforms: Doing Business Case Study. Washington DC: World Bank.

Rangarajan, L. N., trans. 1992. Kautilya, the Arthashastra. Edited, rearranged, and introduced by New Delhi: Penguin Books India. 
Revenue Canada, Customs, Excise, and Taxation. 1993. "Processing of Income Tax Returns for Individuals in a Self-Assessment System.” Revenue Canada, internal document.

Ribot, Jesse. 2000. "Representation and Accountability in Decentralized Sahelian Forestry: Legal Instruments of Political-Administrative Control." Georgetown International Environmental Law Review: 505-67.

Ryesky, Kenneth. "Tax Simplification: So Necessary and So Elusive." Pierce Law Review 2/2: 96.

Sadka, Efriam, and Vito Tanzi. 1993. "A Tax on Gross Assets of Enterprises as a Form of Presumptive Taxation." Bulletin for International Fiscal Documentation 47 (2): $66-73$.

Sarker, T., and Y. Kitamura. 2006. "Technical Assistance in Fiscal Policy and Tax Administration in Developing Countries." The State of Nature in Bangladesh, Keio University, Tokyo.

SCM Network. (date unknown). "How to Reduce Administrative Burdens? The Standard Cost Model method!" http://www.administrative-burdens.com/default. asp?page=122 [accessed May 17, 2008].

Schumpeter, Joseph A. 1991. "The Crisis of the Tax State" [1918]. In Richard Swedberg, ed., The Economics and Sociology of Capitalism, 100. Princeton, N.J.: Princeton University Press.

Shah, Anwar, ed. 1995. Fiscal Incentives for Investment and Innovation. Washington, DC: Oxford University Press.

Shekidele, C. 1999. "Measuring the Compliance Cost of Taxation: Excise Duties 1995-96." African Journal of Finance and Management 7(2): 72-84.

Shome, Parthasarathi. 2004. "Tax Administration and the Small Taxpayer." IMF Policy Discussion Paper 04/02, Washington, D.C.: International Monetary Fund. http:// www.imf.org/external/pubs/ft/pdp/2004/pdp02.pdf.

Silvani, Carlos, and Katherine Baer. 1997. "Designing a Tax Administration Reform Strategy: Experiences and Guidelines.” Working Paper, Washington, DC: International Monetary Fund.

International Monetary Fund. Silvani, Carlos, and Katherine Baer. 1996. "The Cost of Taxation and the Marginal Efficiency Cost of Funds." IMF Staff Papers 43: 172-98.

Silvani, Carlos, and Katherine Baer. 1998. "Tax Avoidance, Evasion and Administration.” Working Paper, University of Michigan, Ann Arbor. Forthcoming in Alan Auerbach and Martin Feldstein, eds., Handbook of Public Economics. Amsterdam: North Holland. 
Slemrod, Joel, and Varsha Venkatesh. 2002. "The Income Tax Compliance Cost of Large and Mid-Sized Business." A Report to the IRS LMSB Division, Office of Tax Policy Research, University of Michigan Business School, Ann Arbor.

Smith, Adam. 2005. "An Inquiry into the Nature and Causes of the Wealth of Nations." Penn State Electronic Classics Series. http://www2.hn.psu.edu/faculty/jmanis/ adam-smith/Wealth-Nations.pdf [accessed May 14, 2008].

Snow, Arthur, and Ronald Warren. 1996. "The Marginal Welfare Cost of Public Funds." Journal of Public Economics 61: 289-305.

Soos, Piroska. 1990. "Self-Employed Evasion and Tax Witholding: A Comparative Study and Analysis of the Issues." U.C. Davis Law Review 24: 107-93.

Steinmo, Sven. 1993. Taxation and Democracy: Swedish, British and American Approaches to Financing the Modern State. New Haven, 167-69 on the Reagan 1986 Tax Reform Act.

Stella, Peter. 1993. "Tax Farming: A Radical Solution for Developing Country Tax Problems?" IMF Staff Papers 40(1): 217-25.

Stern, RichardE., and Paul A. Barbour. 2005. "Designing a Small Business Tax System That Enhances Growth: Lessons from Africa." http://www.itdweb.org/smeconference/ documents/3\%20africa\%20fias.pdf.

Stotsky, Janet G., and A. WoldeMariam. 2002. "Central American Tax Reform: Trends and Possibilities." Working Paper WP/02/227, Washington DC: International Monetary Fund.

Strauss, Julia C. 2008. "Rethinking Institutional Capacity and Tax Regimes: The case of the Sino-Foreign Salt Inspectorate in Republican China." In Deborah Brautigam and others (2008), p. 229.

Taliercio, Robert. 2004. "Designing Performance: The Semi-Autonomous Revenue Authority Model in Africa and Latin America." Policy Research Working Paper 3423, Washington, DC: World Bank.

Tanzi, Vito. 1977. "Inflation, Lags in Collection, and the Real Value of Tax Revenue." IMF Staff Papers 24: 154-67.

Tanzi, Vito, and Milka Casanegra de Jantscher. 1987. "Presumptive Income Taxation: Administrative, Efficiency and Equity Aspects." Working Paper No. 87/54, Washington, DC: International Monetary Fund,.

Tanzi, Vito, and Milka Casanegra de Jantscher. 1996. "VAT in Ghana: Why It Failed." Tax Notes International 12 (23): 1801-16. 
Tanzi, Vito, and Milka Casanegra de Jantscher. 2003. "Managing Small and MediumSized Taxpayers in Developing Countries." Tax Notes International 29 (13 January): 211-34.

Tanzi, Vito, and Milka Casanegra de Jantscher. 2006. "Improving Taxpayer Accounting for SMEs and Individuals." Andrew Young School of Policy Studies, Annual Conference on Public Finance Issues.

Thuronyi, Victor, ed. 1996. Tax Law Design and Drafting, Vol 1. Washington, DC: International Monetary Fund.

Torgler, Benno. 2007. “Tax Compliance and Tax Morale.” London: Madison Books.

Torgler, Benno, and others. 2007. "Tax Compliance, Tax Morale and Governance Quality.” Working Paper 2007/17, p. 32.

Transparency International. 2002. "Corruption in South Asia." Berlin: Transparency International (India survey by S. D. Sharma, Admiral R. H. Tehliani, Ramakrishna, and S. S. Mehta).

Treisman, Daniel. 2006. "Fiscal Decentralization, Governance, and Economic Performance: A Reconsideration.” Economics and Politics 18 (2) (July): 219-35.

U.S. Department of Justice. 2004. "Foreign Corrupt Practices Act (FCPA)" (U.S. Department of Justice 2004) http://www.usdoj.gov/criminal/fraud/fcpa/ [accessed May 8, 2008].

U.S. Internal Revenue Service. 1997. "Taxpayer Bill of Rights 2.” Training Publication. http://www.irs.gov/pub/irs-utl/doc7394.pdf.

U.S. Internal Revenue Service. 2001. "The National Taxpayer Advocate's Fiscal Year 2002 Objectives Report to Congress.” http://www.irs.gov/pub/irs-utl/tas02obj. pdf.

U.S. Internal Revenue Service. 2008. "Internal Revenue Manual-1.1.8 National Taxpayer Advocate.” http://www.irs.gov/irm/part1/ch01s07.html.

Usui, Nobuaki. 2002. "Penetration of the Self-Assessment System for Income Tax: Halfa-Century's Experience in Postwar Japan." Paper presented at the conference, "New Challenges in Tax Compliance: Japan's Experience and Its Significance."

Vaillancourt, François. 1987. "The Compliance Costs of Taxes on Businesses and Individuals: A Review of the Evidence.” Public Finance 42: 395-414.

Vaillancourt, François. 1999. "Les coûts de conformité à la fiscalité des firmes et des individus : Une recension des écrits." L'Actualité économique 75(1-2-3) (MarchJune-September): 215-37. 
Vaillancourt, François, Jason Clemens, and Milagros Palacios. 2007. "Compliance and Administrative Costs of Taxation in Canada." Vancouver: Fraser Institute. http:// www.fraserinstitute.org/COMMERCE.WEB/product_files/TaxComplianceDec07.pdf.

Vanistendael, Frans. 1996. "Legal Framework of Taxation.” In Victor Thuronyi, ed., (1996), 15-70.

Vazquez-Caro, Jaime, Gary Reid, and Richard Bird. 1992. "Tax Administration Assessment in Latin America." Latin America and the Caribbean Technical Department, Regional Studies Program, Report No. 13, Washington, DC: World Bank.

Vogl, Frank. 1998. "The Supply Side of Global Bribery." Finance E Development 35(2).

Vording, Henk. 1997. "Chinese Tax Policy and the Problem of Fairness in Taxation." In Yong Zhang and Toshiro Fuke, eds., Changing Tax Law in East and Southeast Asia Towards the 21st Century, 91-110.

Wahrman, Dror. 1995. "Imagining the Middle Class: The Political Representation of Class in Britain c.1780-1840.” Cambridge: Cambridge University Press.

Wallschutzsky, Ian. 1989. "Achieving Compliance in Developing Countries." Bulletin for International Fiscal Documentation 43: 234-44.

Wallschutzsky, Ian. 1991. "Australia: Reforming a Tax System to Reduce Opportunities for Tax Evasion.” Bulletin for International Fiscal Documentation 45: 65-75.

Wilensky, H. 2002. "Rich Democracies: Political Economy, Public Policy, and Performance." Berkeley: University of California Press.

Winters, J. A. 1996. "Power in Motion: Capital Mobility and the Indonesian State." Ithaca, NY: Cornell University Press.

Witt, M. February 2007. Entwicklung und Zusammenarbeit 48 (2): 59-62.

WoldeMariam, A. 1997. "Tax Effort in Sub-Saharan Africa." Working Paper WP/97/107, Washington, DC: International Monetary Fund.,

World Bank and PriceWaterhouseCoopers. 2007. Paying Taxes: The Global Picture. http://www.doingbusiness.org/documents/DB_Paying_Taxes.pdf.

World Bank and PriceWaterhouseCoopers. 2008. Paying Taxes 2008: The Global Picture. http://www.doingbusiness.org/documents/Paying_Taxes_2008.pdf.

World Bank and International Finance Corporation. 2008. Doing Business 2009. http:// www.doingbusiness.org/documents/FullReport/2009/DB09_Full_Report.pdf.

World Bank, Foreign Investment Advisory Service (FIAS). 2007. "South Africa: Tax Compliance Burden for Small Businesses: A Survey of Tax Practitioners." http:// www.fias.net/ifcext/fias.nsf/AttachmentsByTitle/FIAS_tax_practioners_report_ SA/\$FILE/FIAS_Tax_Practitioners_Report_-_FINAL_29+Aug.pdf. 
World Bank. 2007. "Informality: Chapter 8: The Informal Sector and the State: Institutions, Inequality, and Social Norms.” http://siteresources.worldbank.org/INTLAC/ Resources/CH8.pdf.

Yang, Dean. 2005. "Integrity for Hire: An Analysis of a Widespread Program for Combating Customs Corruption." Ford School of Public Policy Working Paper Series 2005-001, University of Michigan, Ann Arbor. http://papers.ssrn.com/paper .taf?abstract_id=649095.

Yaniv, Gideon. 1988. "Withholding and Non-Withheld Tax Evasion." Journal of Public Economics 35: 183-204.

Zakaria, Fared. 2003. The Future of Freedom: Illiberal Democracy at Home and Abroad. New York: W. W. Norton \& Company. p. 76.

Zee, Howell H., Janet G. Stotsky, and Eduardo Ley. 2002. "Tax Incentives for Business Investment: A Primer for Policy Makers in Developing Countries." World Development, 30 (September): 1497-516.

Zhu, Ze, and Barbara Krug. 2005. "China's Emerging Tax Regime: Local Tax Farming and Central Tax Bureaucracy." ERIM Report Series Research in Management, ERS-2005-088-ORG, Erasmus University, Rotterdam. http://papers.ssrn.com/sol3/ papers.cfm?abstract_id $=902735$. 
